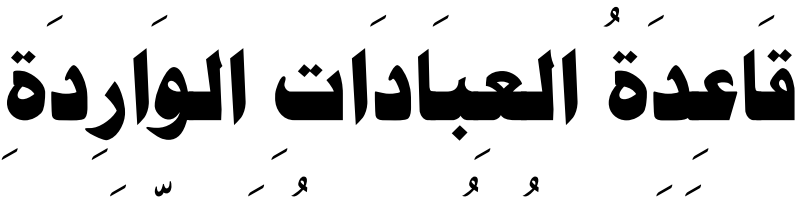 على وجوهِ هتعددة
}

\author{
دراسة تأصيلية تطبيقية

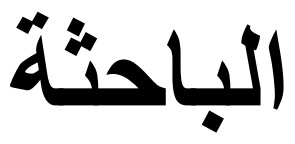 \\ وفاء بنت عبد الرحمن السويداء
}


$-1 \leqslant \Lambda r-$ 


$$
\begin{aligned}
& \text { ملخ بح }
\end{aligned}
$$

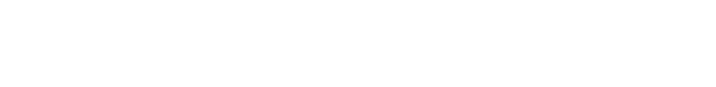

من محاسن الشريعة الإسـلامية أنها جعلت لبعض العبادات صفات

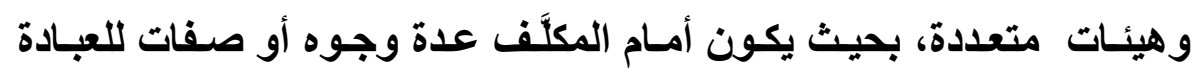
الواحدة، له أن يختار منها ما يشاء، فيختار من العمل أحد وجوهـه الثابتة،

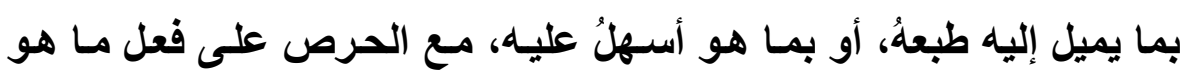

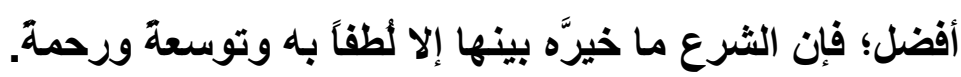

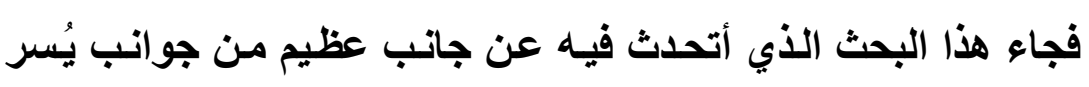

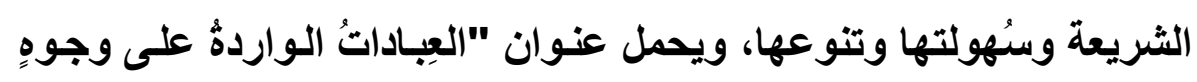
متعددةٍ دراسة تأصيلية تطبيقية"، ونئية

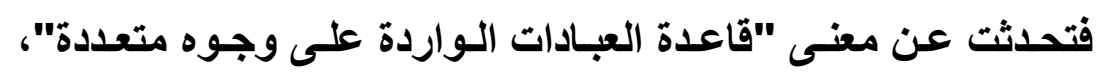

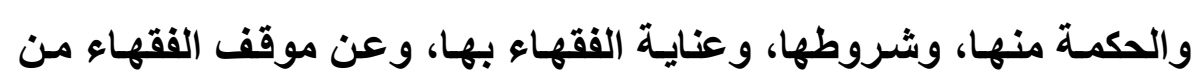
العبادات الواردة على وجوه متعددة.

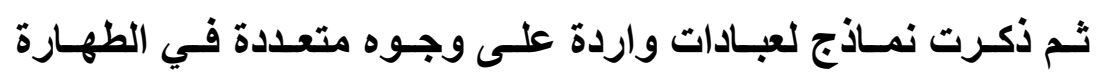
والصلاة، ونماذج لعبادات واردة على وجوه متعددة في الصيام والحج. والله ولى التوفيق 
Abstract

The rule of worship is contained on multiple faces One of the virtues of Islamic law is that it has made certain acts of worship a number of attributes and bodies, so that the taxpayer has several faces or attributes of the same worship, he has to choose from them what he wants, choose from work one of his fixed faces, tends to print, or easier, To do what is better; the Sharia is the best among them except for kindness, expansion and mercy.

This research, which I am talking about, is about a great aspect of the law, its ease and variety. It carries the title "

It spoke about the meaning of "the rule of worship on multiple faces", the wisdom of it, its conditions, and the attention of the jurists, and the position of the jurists of the acts of worship on multiple faces.

Then the models of the incoming worshipers were reported on multiple faces in purity and prayer, and models of the worshipers featured on multiple faces in fasting and pilgrimage. 


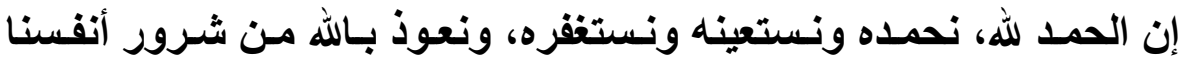

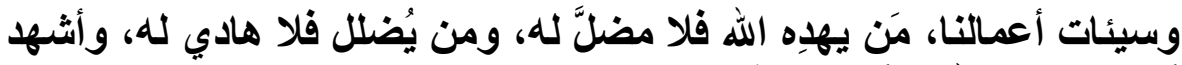

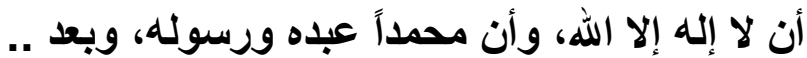

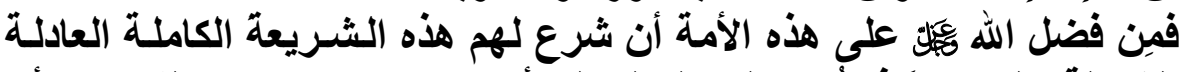

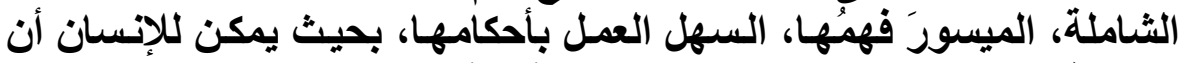

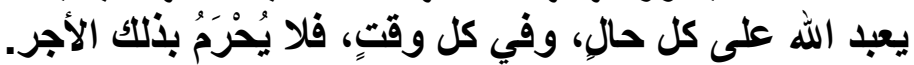

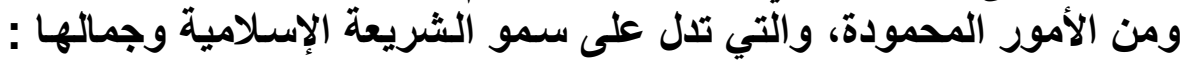

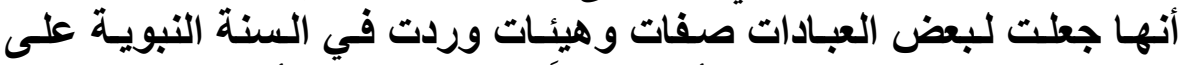

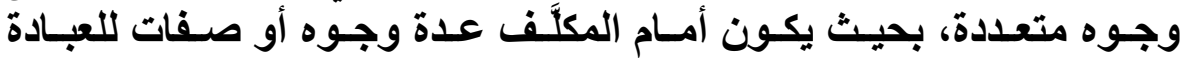

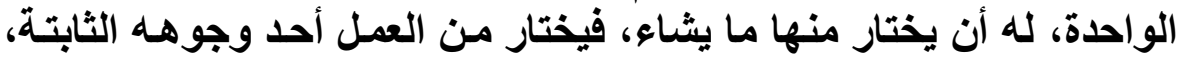

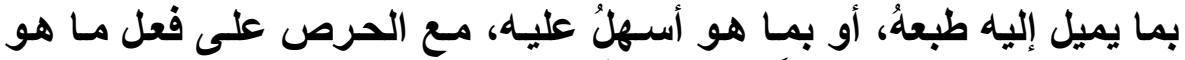

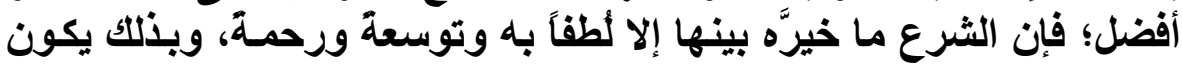
متابعاً للنبي

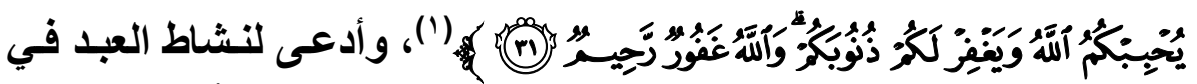

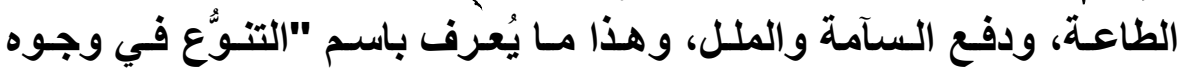

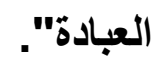

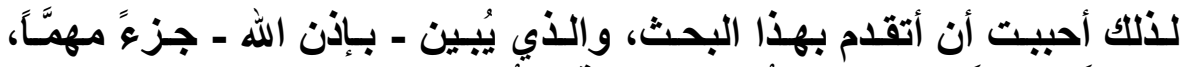

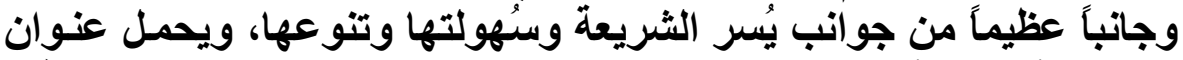

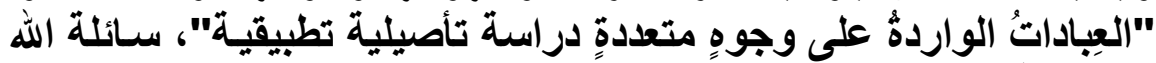

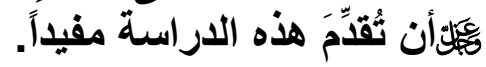

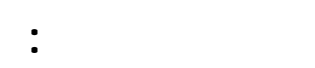

إن لهذا الموضوع أهمية كبرى، تثضح من فئه خلال عدة أمور، منها:

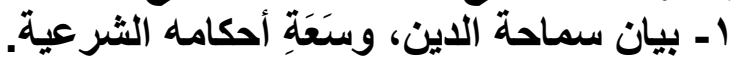

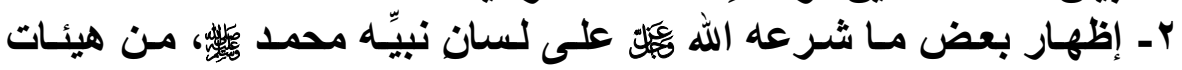

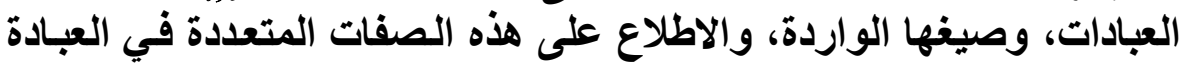
الوا الودة.

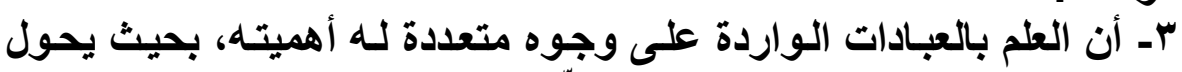
دون التعصب، والتفرق، والتنازع، ويحقّق التآلف واجتماع التّأ التوب. 


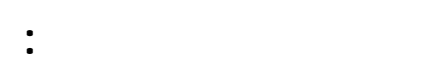

لقد اخترت هذا الموضوع لأسباب متعددة، منها ما يلي:

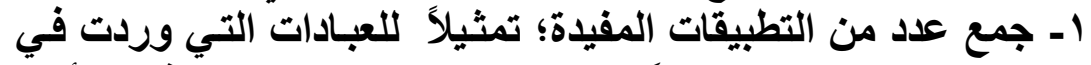

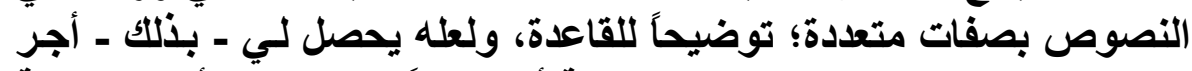

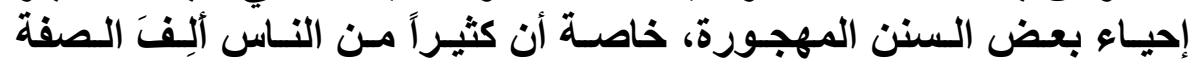

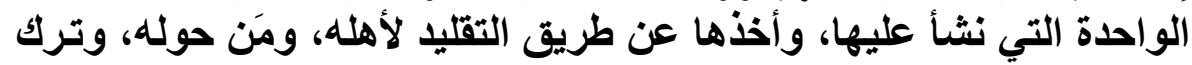

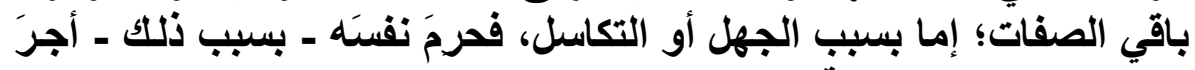

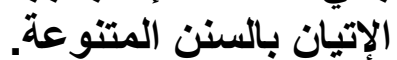
r- بيـان آراء الفقهاء، وإبـراز أوجـه النظر والأدلـة التـي يستنذون rـ ــ عدم وجود بحث ـ بحسب مـا اطلعت عليه ـ قـام بتأصيل القاعدة و التوسع في التمثيل عليها. يتكون البحث من : مقدمة، ومحبثين، وخاتمهاه، وفهارس.

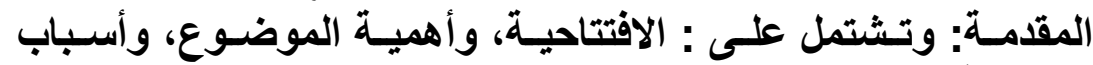

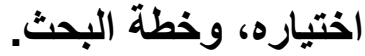

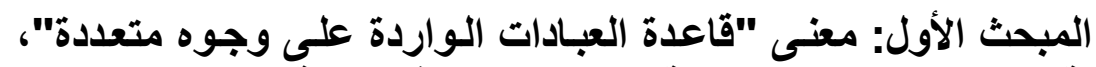
والحكمة منها، وشروطها، وعناية الفقهاء بها. وفيه ثلاثة مطالب:

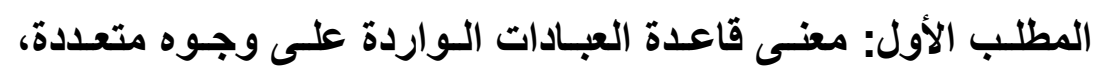
المطلب الثاني: الحكمة من مشروعية تعدُد وجوه العبادات. ومفهومها. المطلب الثالث: شروط العمل بالوجوه المتعددة للعبادات.

المبحث الثاني: موقف الفقهـاء مـن العبـادات الـواردة على وجـوه متعددة. وفيه مطلبان

المطلب الأول: موقف الفقهاء من العبادات الواردة على وجوه متعددة،

المطلب الثناني: موقف الفقهـاء مـن العبـادات الـواردة على وجـوه مين حيث الترجيح والتخيير. متعددة، من حيث المداومة والجمع. 
المبحـث الثالــ: عبسادات واردة علـى وجـوه متعـددة في الطهـارة والصلاة. وفيه ثلاثنة مطالب:

المطلب الأول: عبادات واردة على وجوه متعددة في الطهارة.

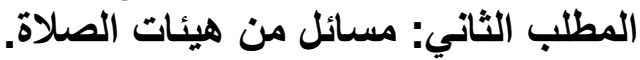

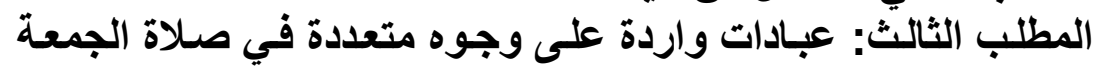
وأحكام الجنازة. وفيه مطلبان:

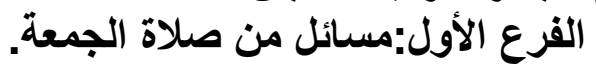
الفرع الثاني: مسائل من أحكام الجنازة.

المبحث الرابع: عبادات واردة على وجوه متعددة في الصيام والحج. وفيه مطلبان:

المطلب الأول: مسائل من الصيام. المطلب الثاني: مسائل من الحنج من الصيام. الخاتمة: وتثتئمل على أهم النتائج.

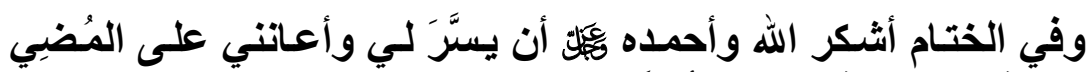
في إتمام هذا البحث، فله الحمد أولاًَ وآخرا.

وصلَّى الله على نبيِّا محمدٍ، وعلى آله وصحبه تسليماً 


\section{المبـث الأول}

\section{معنى "قاعدة العبادات الواردة على وجوه متعددة"، والمكمة}

\section{منها، وشروطها، وعناية النقهاء بها.}

فيه ثلاثة مـ ال

• المطلب الأول: معنى قاعدة العبـادات الواردة على وجوه متعددة،

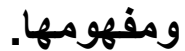
• المطلب الثاني: الحكمة من مشروعية تعدُّد وجوه العبادات. • المطلب الثالث: شروط العمل بالوجوه المتعددة للعبادات.

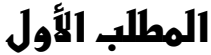

\section{معنـى قا عدة العبادات الواردة على وجوه متعددة، ومفهومها}

معن لعبا

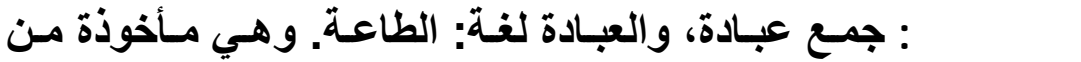

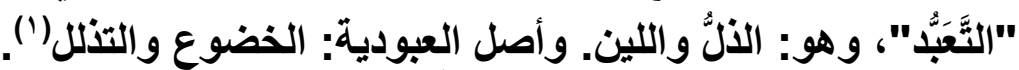

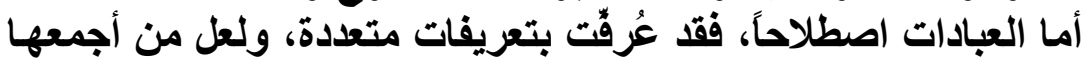

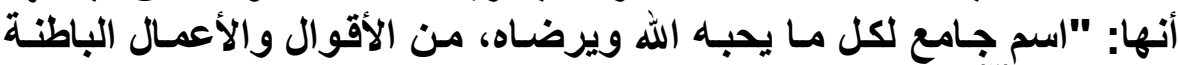

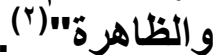
فالمناسبة بين المعنى اللغوي والاصطلاح الشـرعي: أن العبادة في

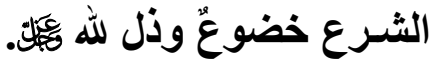
مل مل لقاء

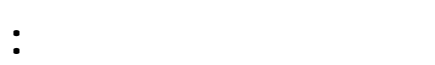

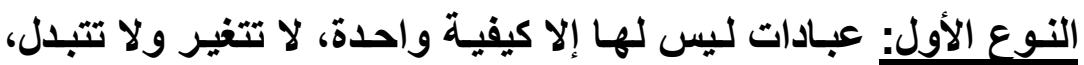

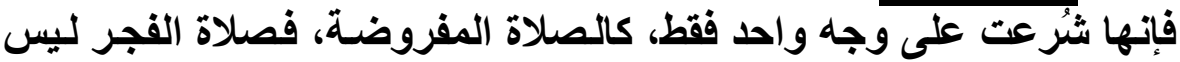

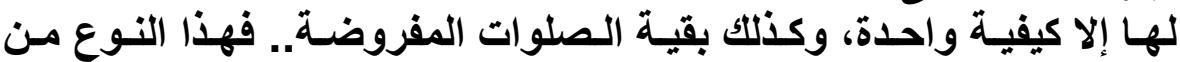

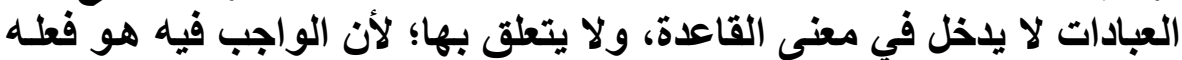

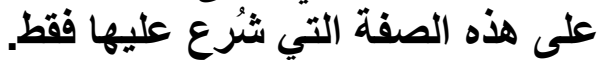

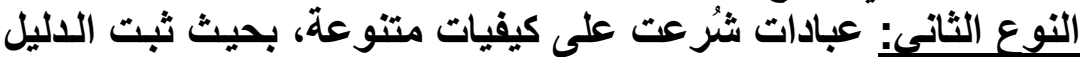

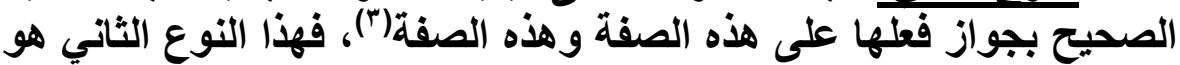

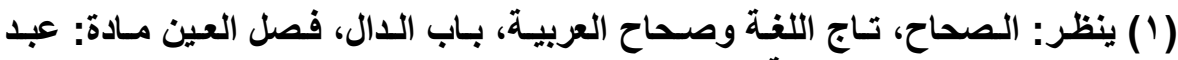

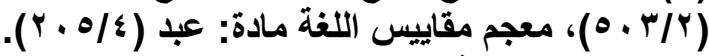


مناط القاعدة.

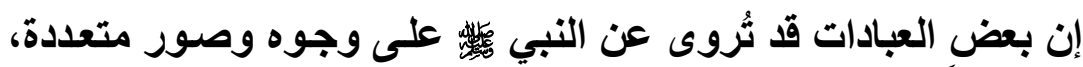

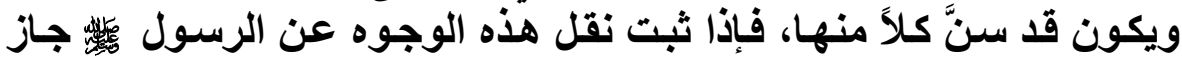

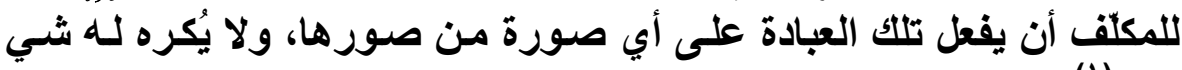

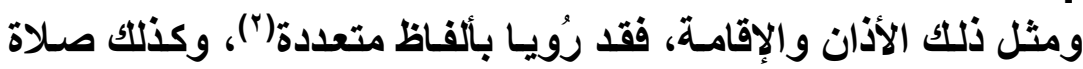
منها" (')

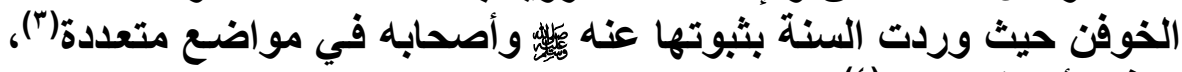

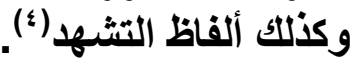
وسوف يتبين لنا صور بعض من هذه العبادات في الباب التطبيقي بإذن الله.

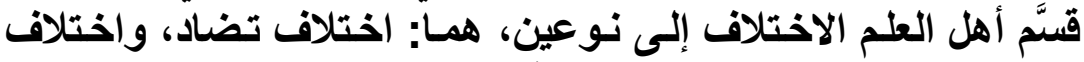

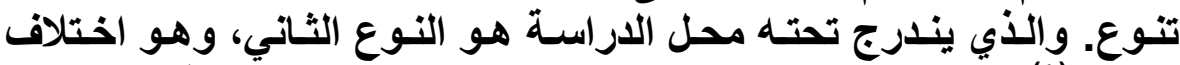

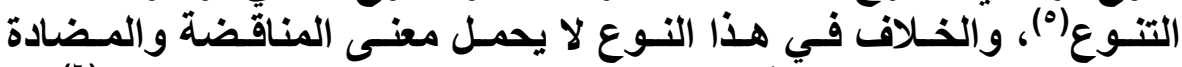

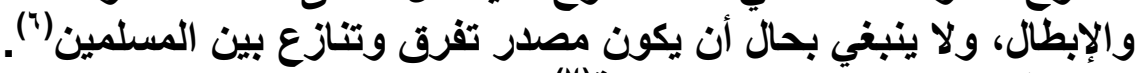

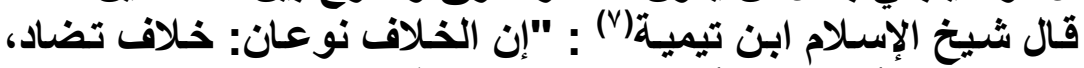

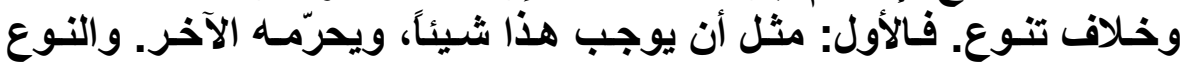

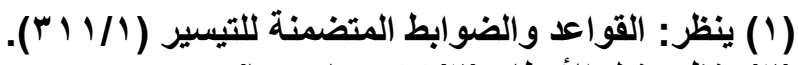

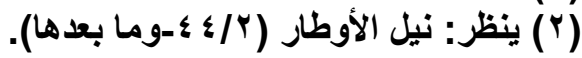

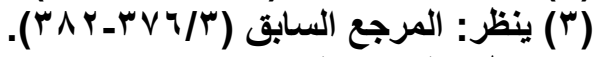

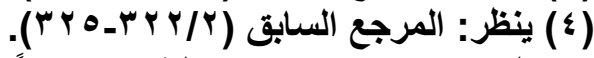

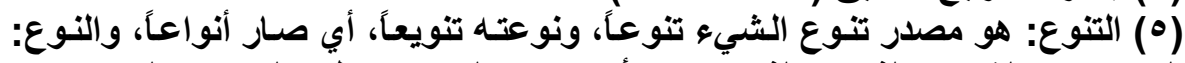

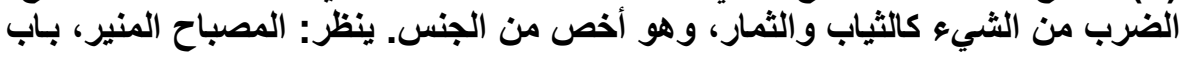

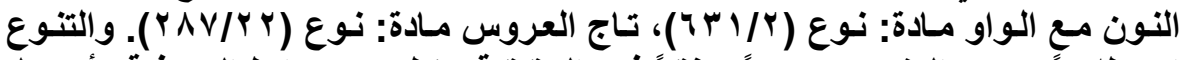

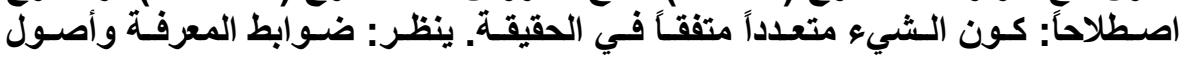

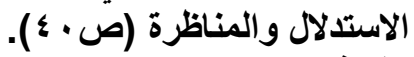

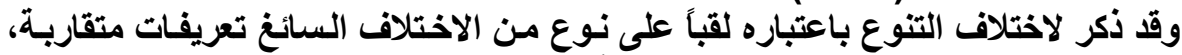

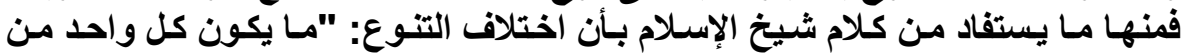

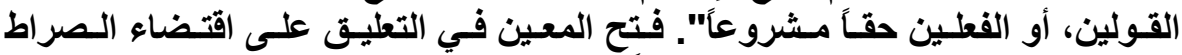

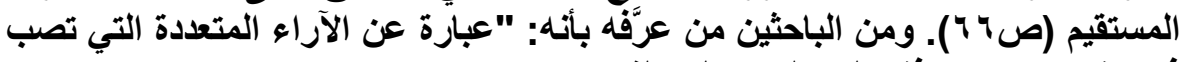

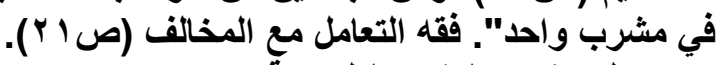

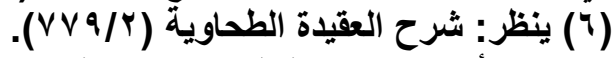

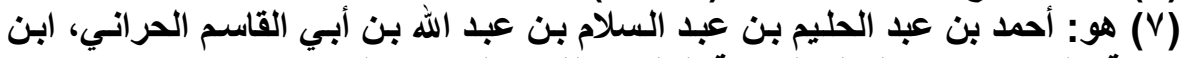

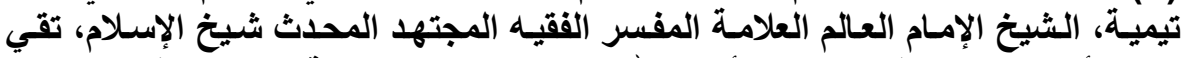

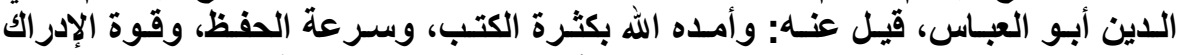

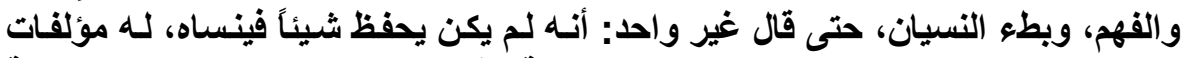

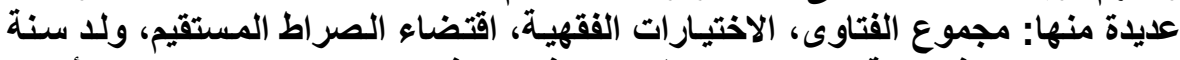

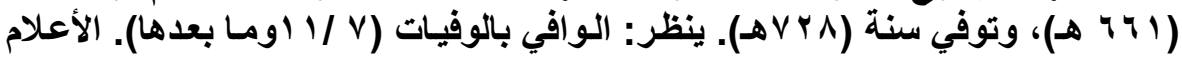


الثاني: مثل القراعات التي يجوز كل منها، وإن كان هذا يختار قراءة، وهذا

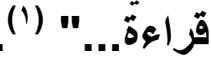
: تسمية لتن

وقد اختلفت تسمية الفقهاء لهذا النوع من العبادات، فمنهم مَن يسميه

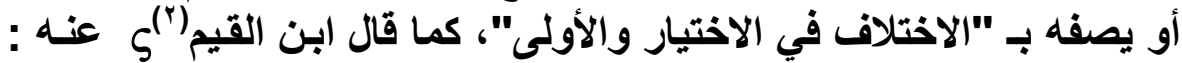

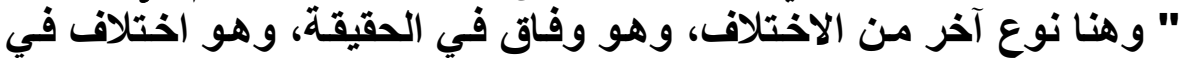

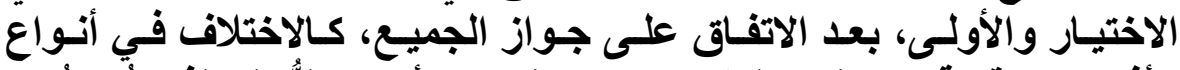

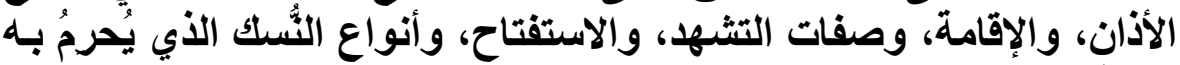

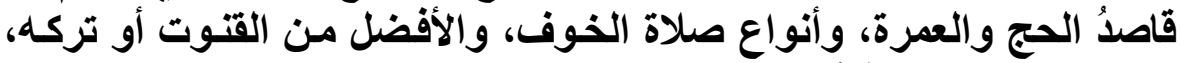

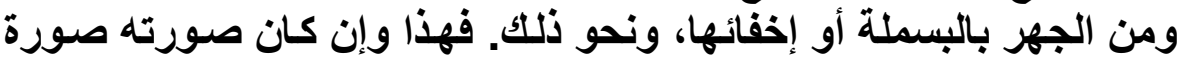

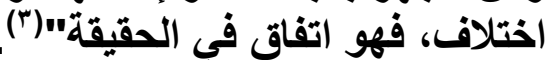

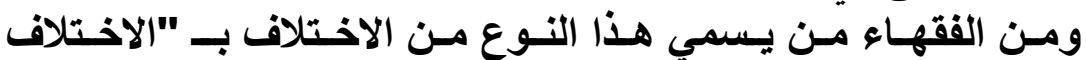

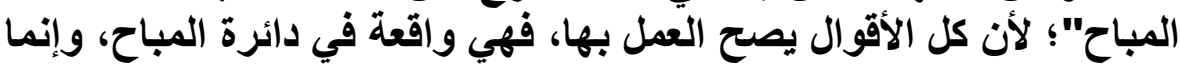

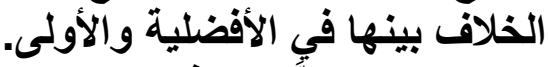

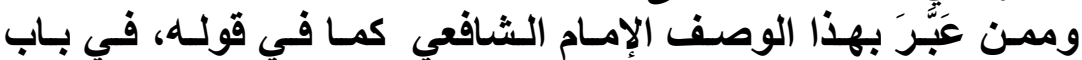

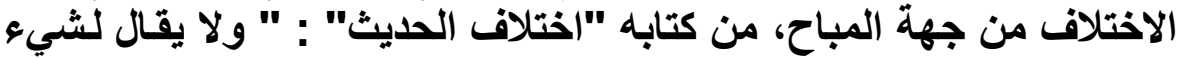

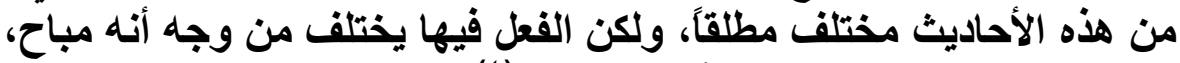

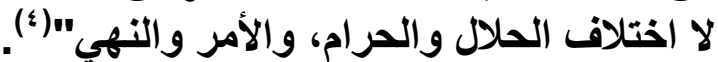

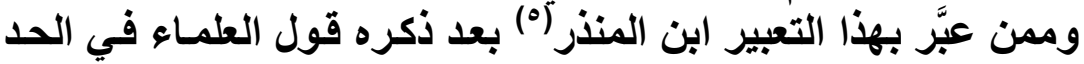

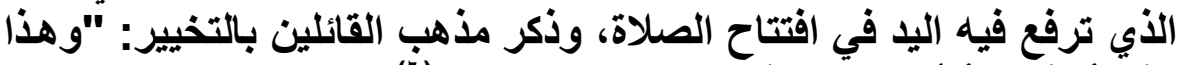

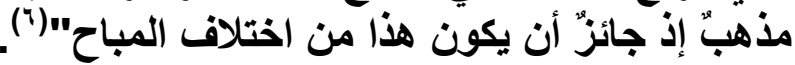

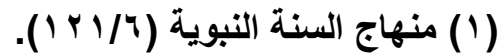

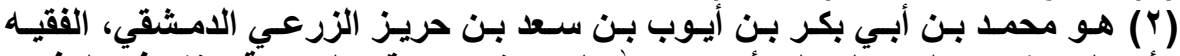

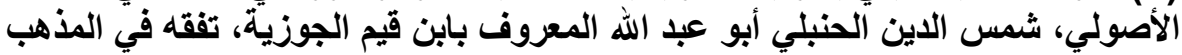

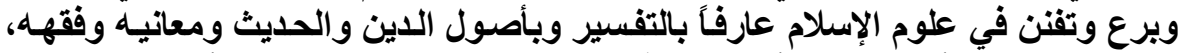

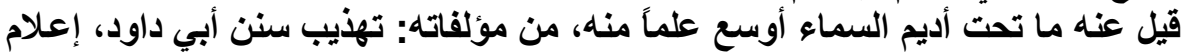

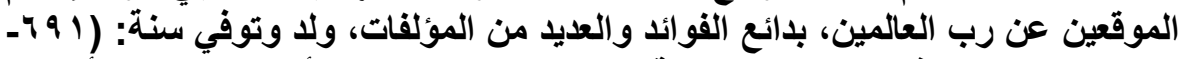

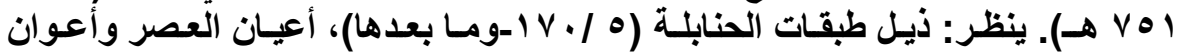

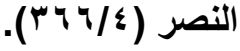

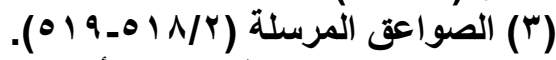

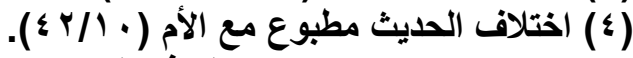

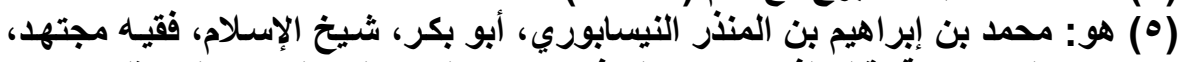

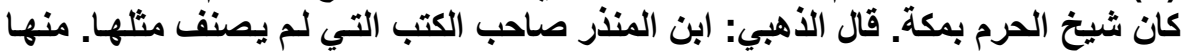

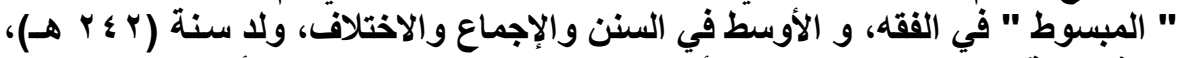

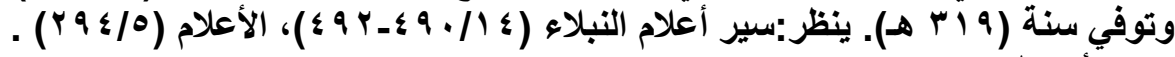


وكنلك ابن القيم لما ذكر اختلاف الفقهاء في القتوت في الفرائض، قال:

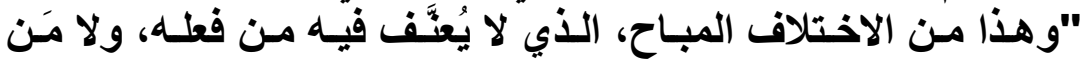
تركه، وهذا كرفح اليدين في الصلاة وتركه، وكالخلاف في أنواع التهاع التشهل، وأنواع الأذان والإقامة...."(')

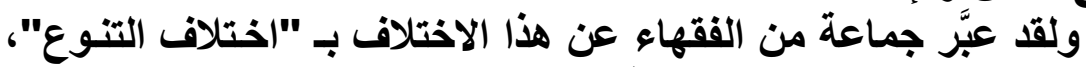

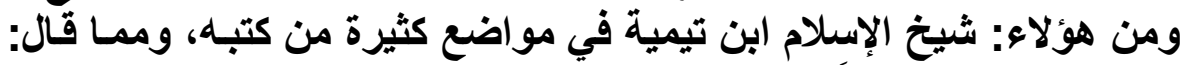

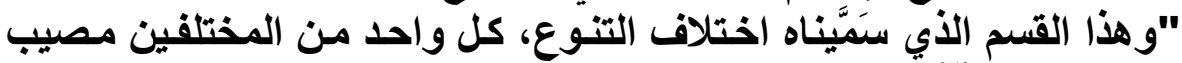

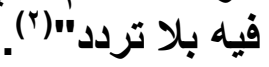

وقال في موضع آخر: "والصحيح الذي لا يجوز أن يقال بغيره: أن كل

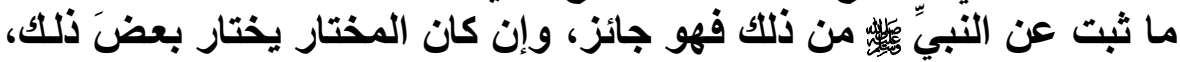

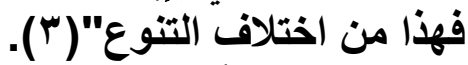
ولهذا فالأقرب من التسميات هو تسميته بـ "اختّلاف التنوع"؛ لأن ذلك الته

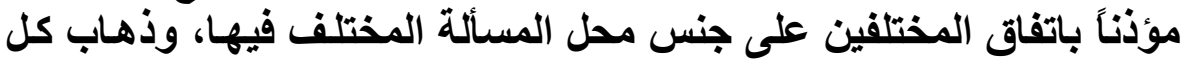

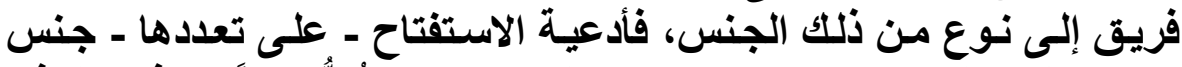

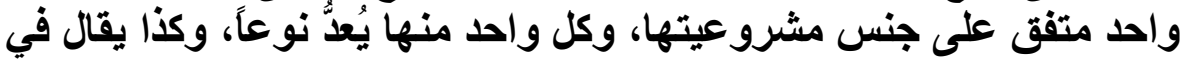

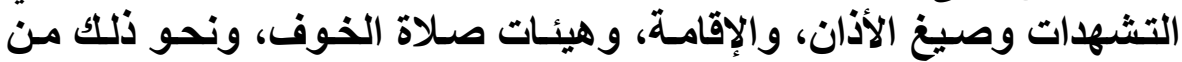

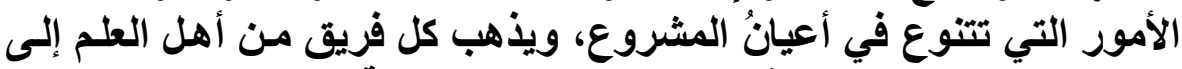

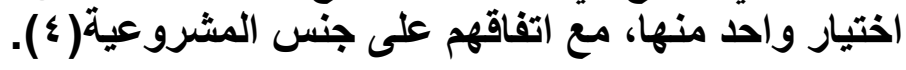

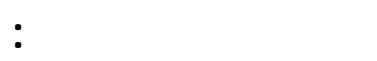

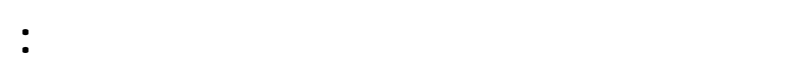

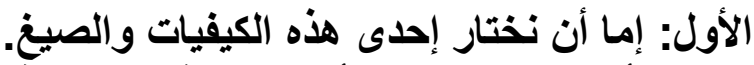

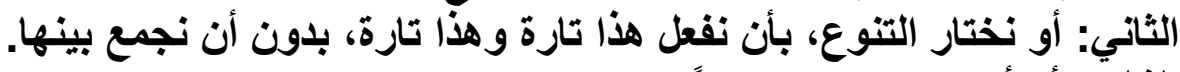
الثالث: أو أن نجمع بينها جميعاً (ه).

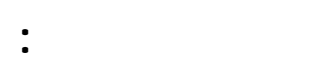

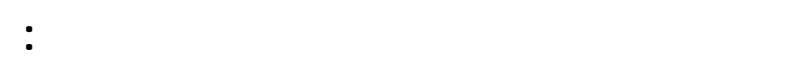

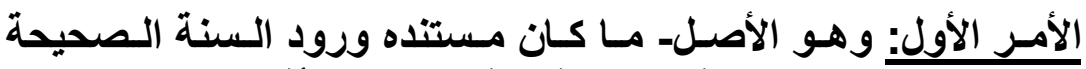

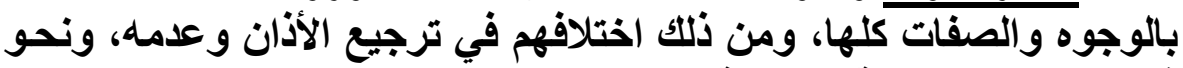
ذلك مما جاعت السنة بشرعية جميعه.

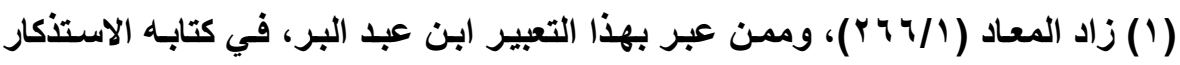
. (YNY/乡) (Y) فتح المعين في التعليق على اقتضاء الصراط المستقيم (ص/9/7).

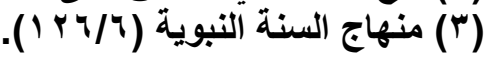

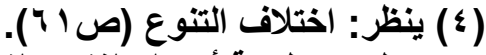
(0) ينظر: منظومة أصول الفقه والقواعد الفقهية (ص1 \&). 


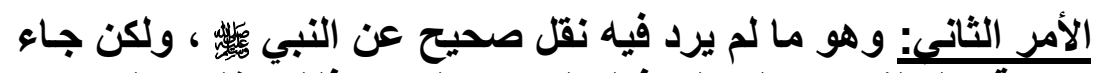

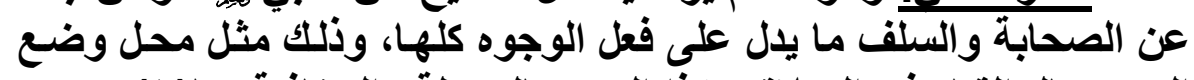

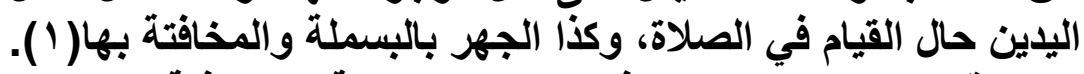

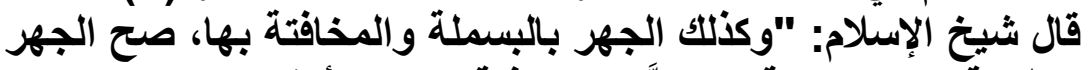

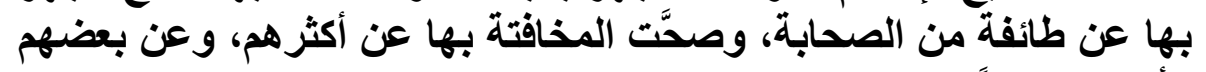

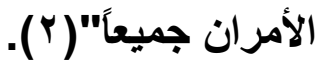

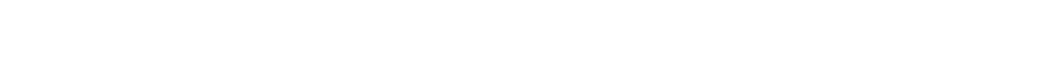
قسا لعبا : لماول:

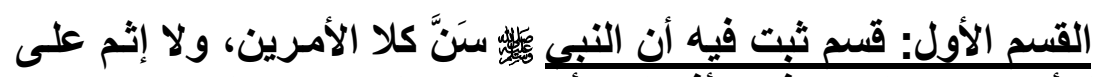

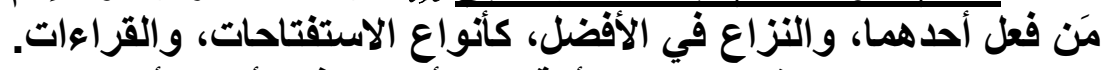

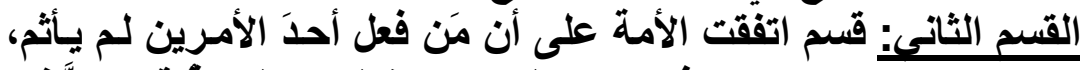

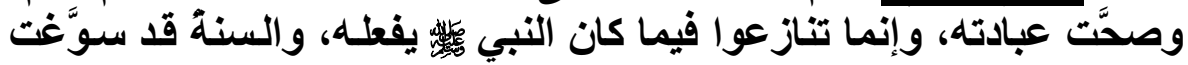

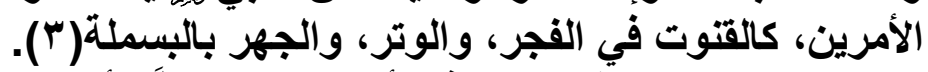

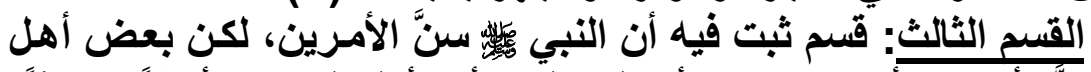

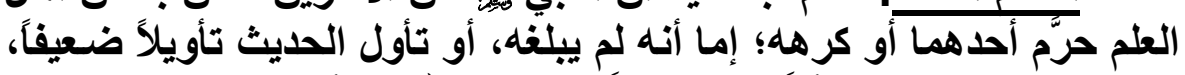

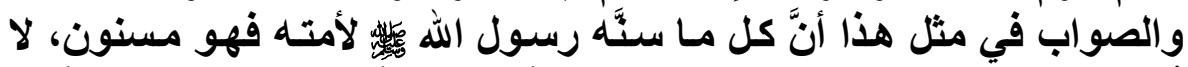

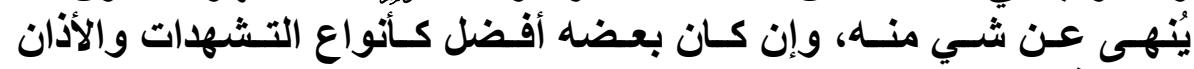
والإقامة (ع) ).

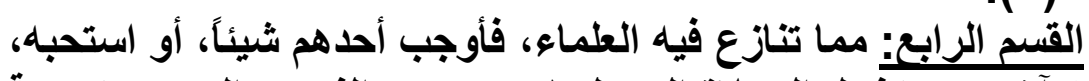

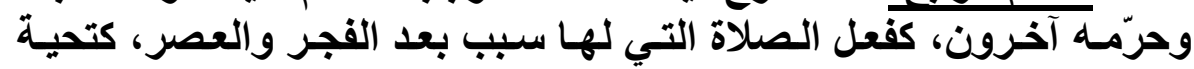

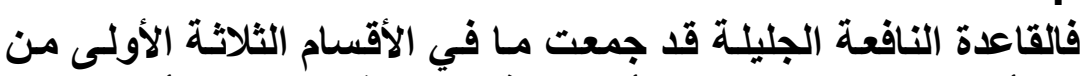

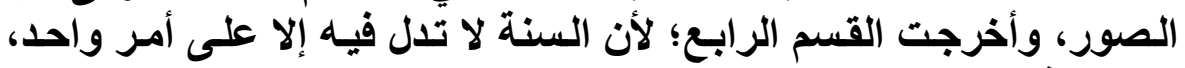
و التعدد فيه غير وارد (ه).

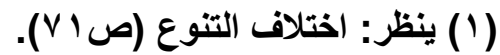

(r)

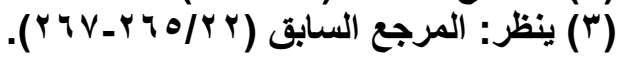

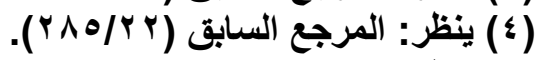

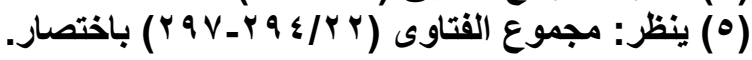




\section{المطلب الثاني}

المكمة من مشروو عية تنعدد وجوه العبـادات

لمسألة لأ له

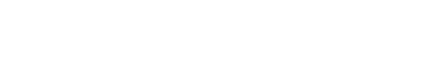

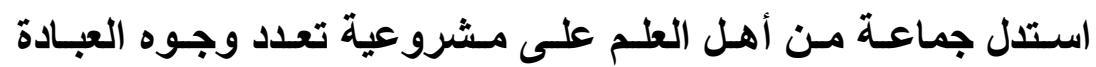

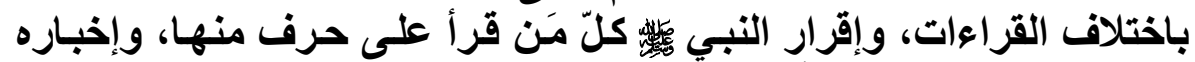

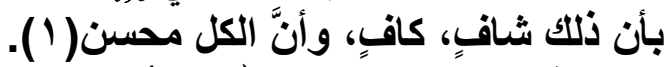

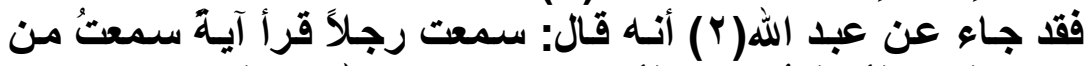

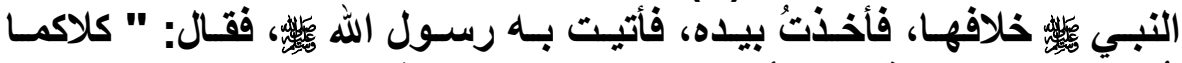

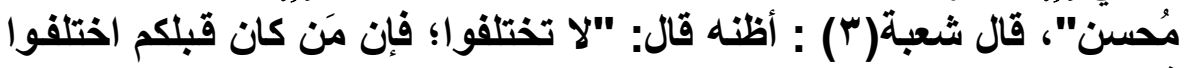

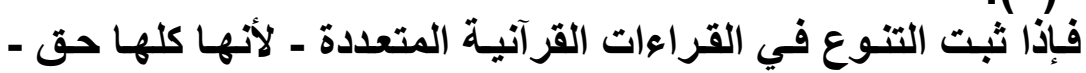

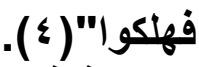

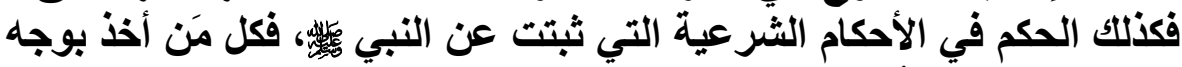
فيها فهو محسن مُصيب.

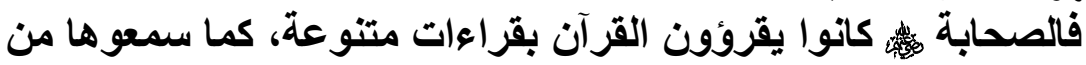

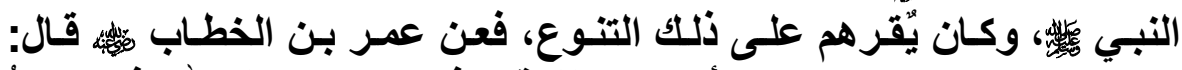
سمعت هثام بن حكيم(0) يقرأ سورة الفرقان في حياة رسول الله، فاستمعتُ فئ

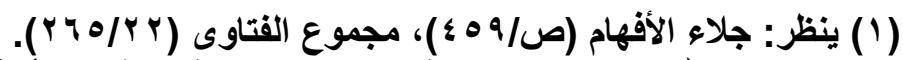

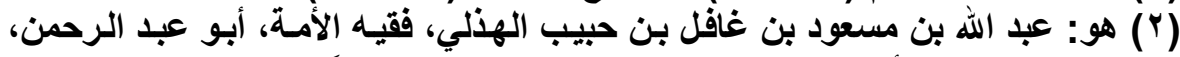

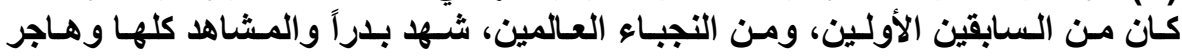

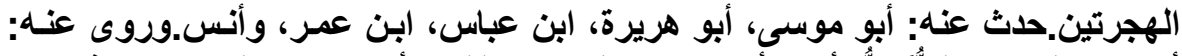

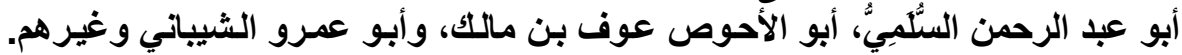

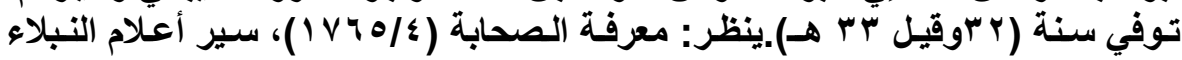

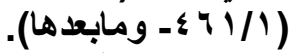

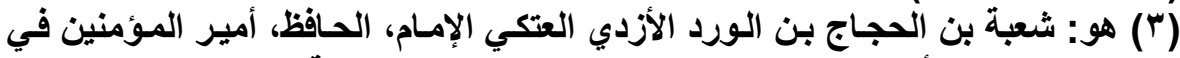

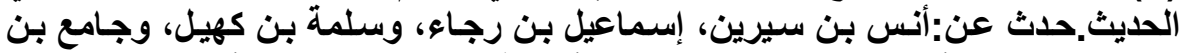

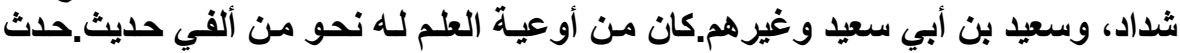

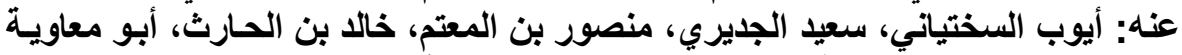

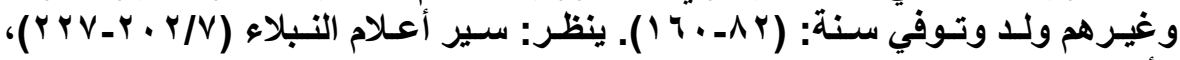

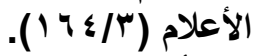

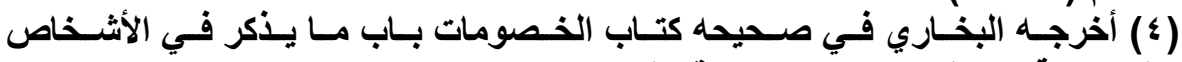

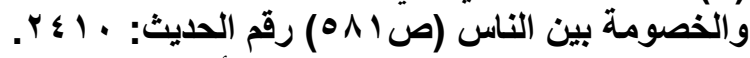

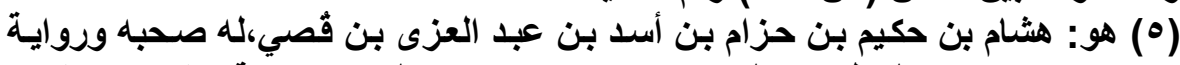

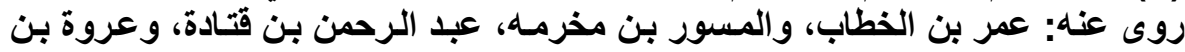

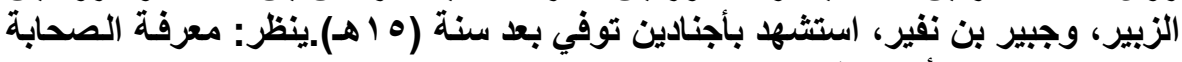
(YVTq/0) 


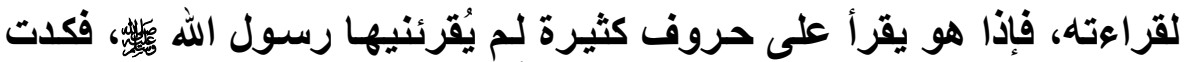

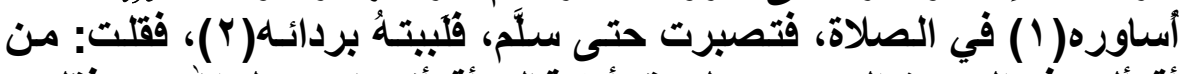

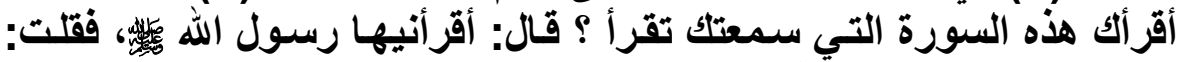

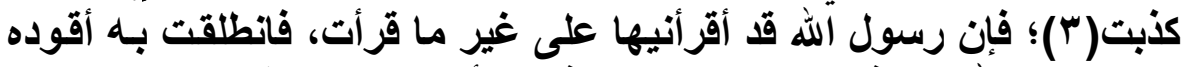

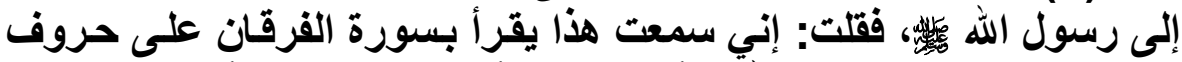

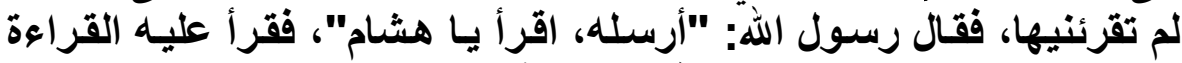

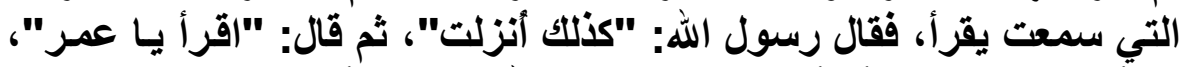

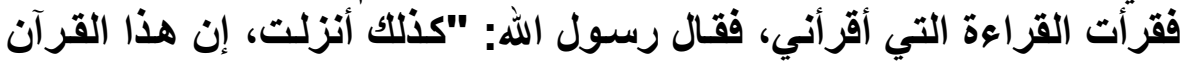

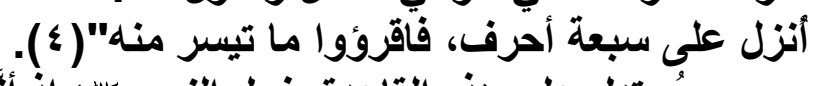

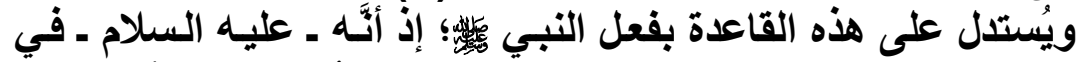

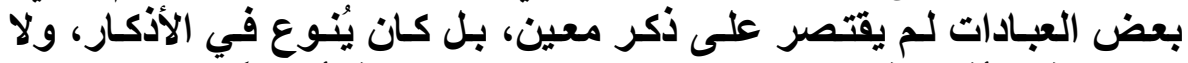

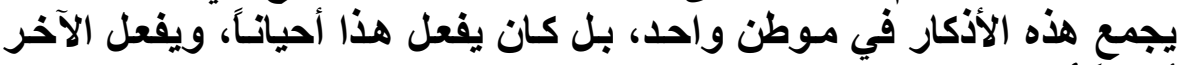

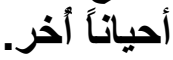

وقد ئقل الإجماع على صحة الأوجه المتعددة في بعض المسائل، كما

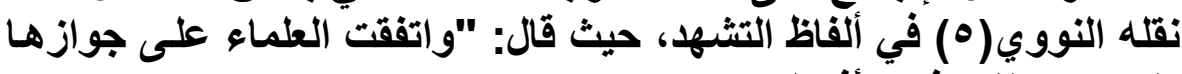

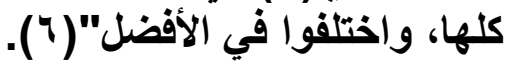
لمسألة لثانية

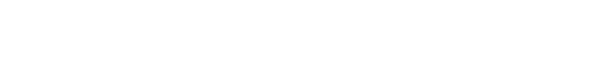

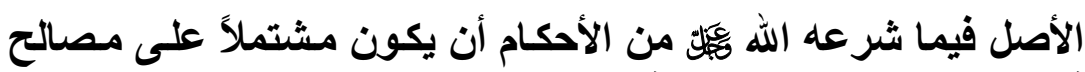

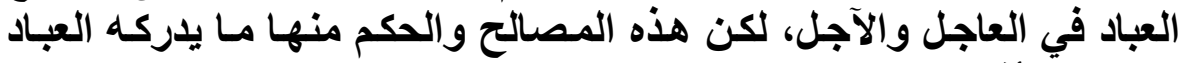

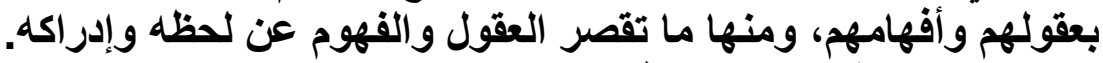

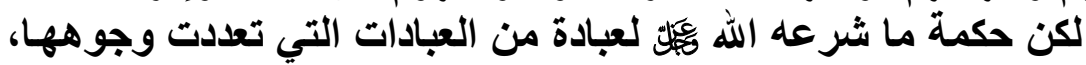

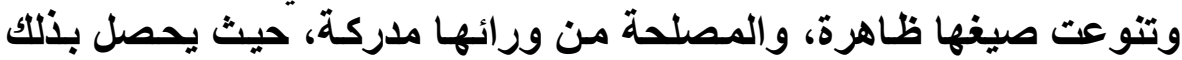

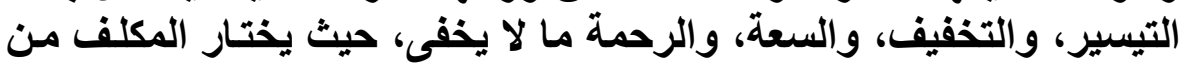

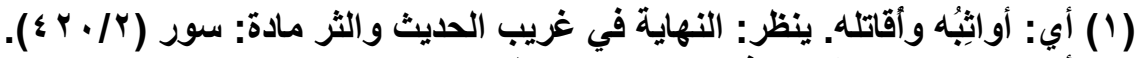

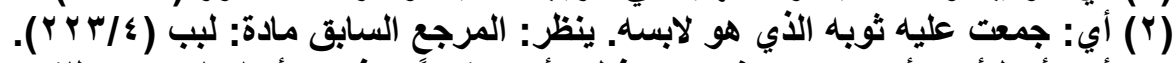

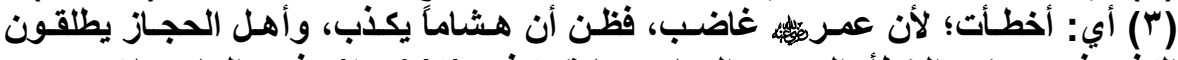

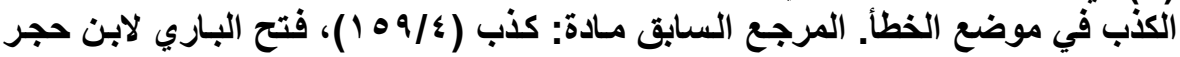
(؛) أخرجها البخـاري في صحيحهن كتاب فضائل القرآن، بـاب أنزل القرآن على سبعة .

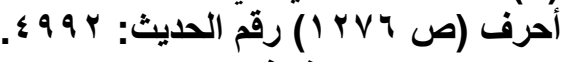

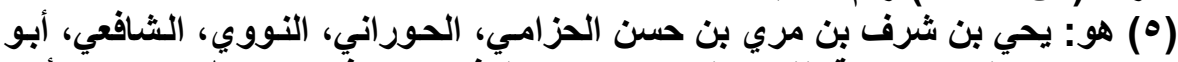

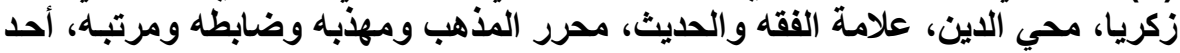

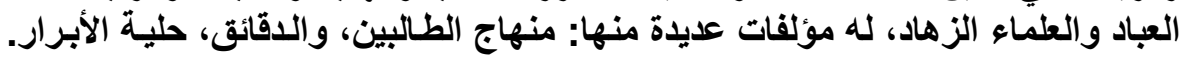

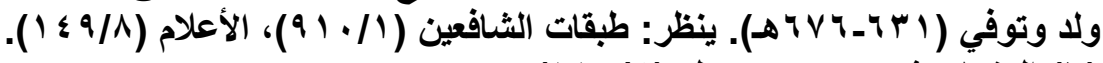

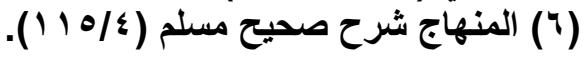




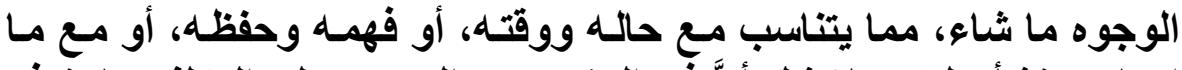

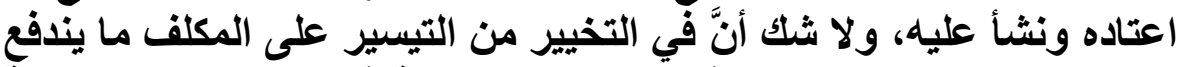

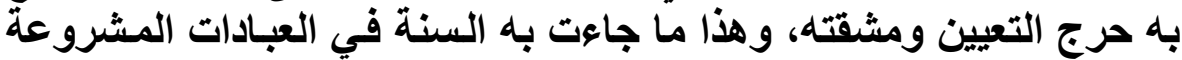

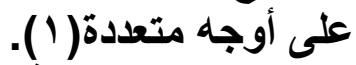

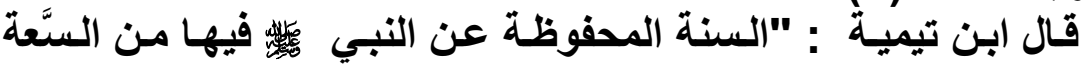

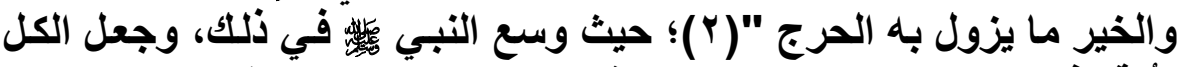

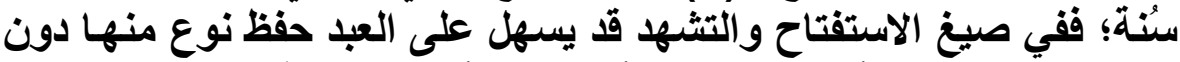

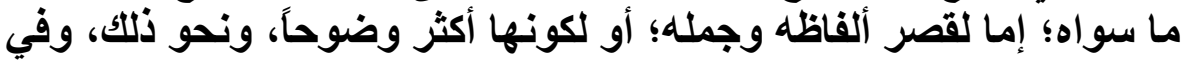

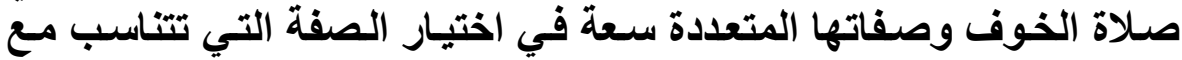

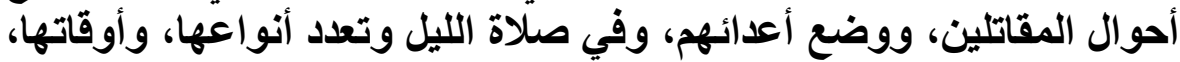

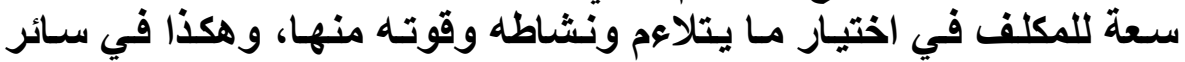

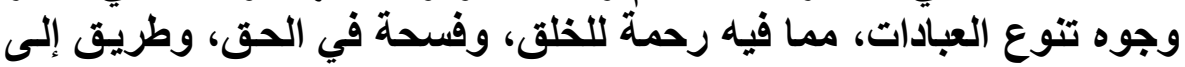
الرفق. وقد كان السلف الصالح يحبون هذه التوسعة على المكلف، ويعدون

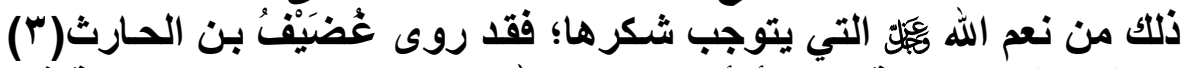

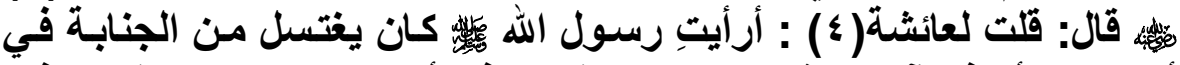

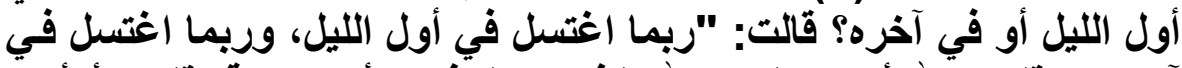

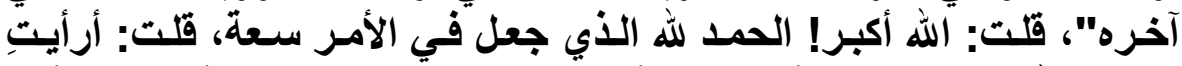
رسول الله

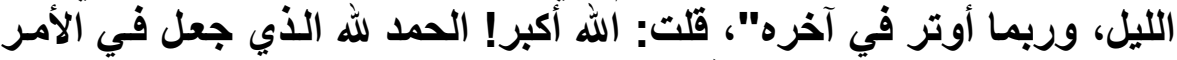

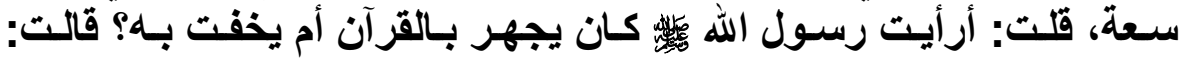
"ربما جهر به، وربما خفت"، قلت: الله أكبر! الحمد لله الذي جعل أن في الأمر

$$
\begin{aligned}
& \text { (1) ينظر: اختلاف التنوع (ص/7 + (1). } \\
& \text { (Y) خلاف الأمة في العبادات (ص/عاء ه). }
\end{aligned}
$$

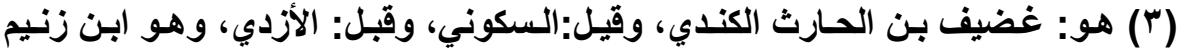

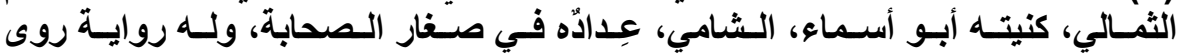

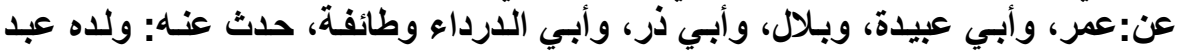

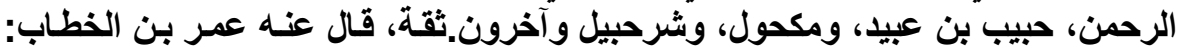

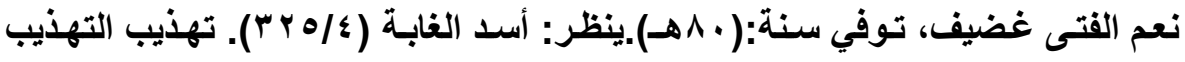
( $r \leqslant \wedge / 1)$

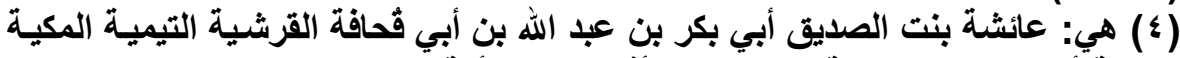

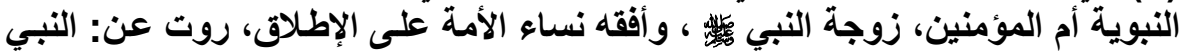

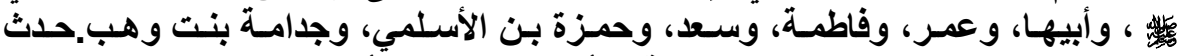

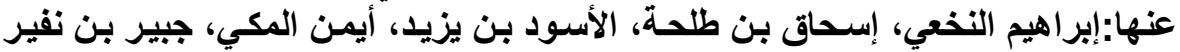

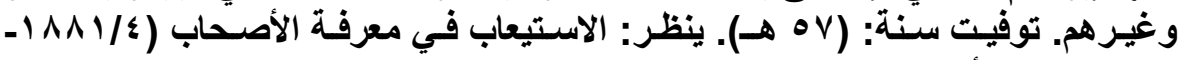

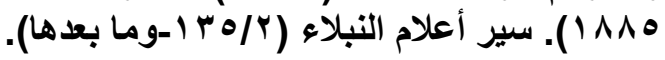




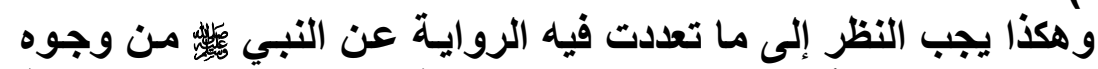

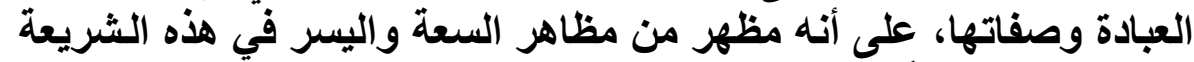

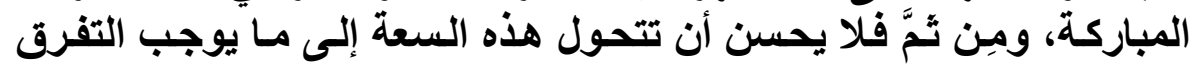

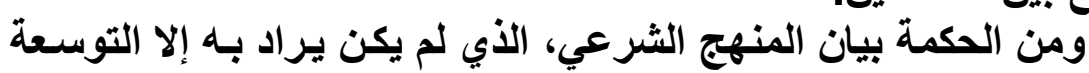

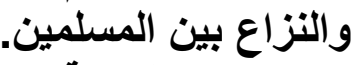

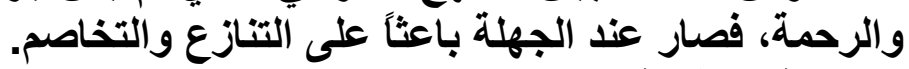

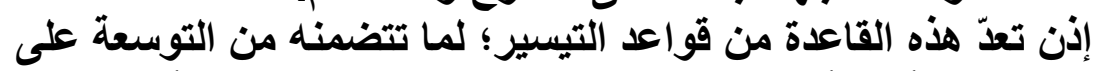

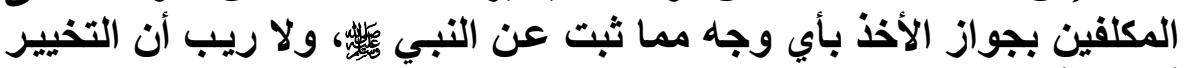
قال الإمام الثشافعي في سياق كلامه عن اختلاف ألفاظ التشهـ : " فباذاذ

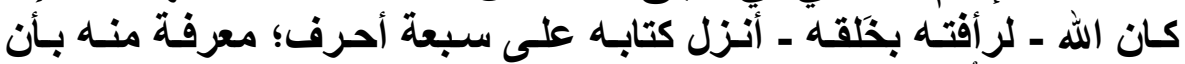

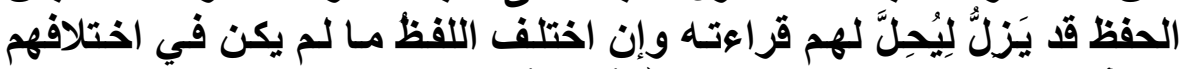

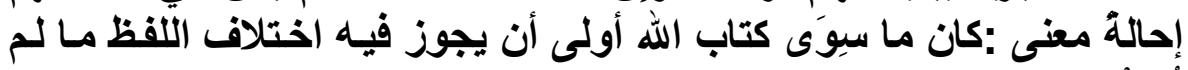

وما يقال في اختلاف اللفظ يقال في اختلاف الوجوه التي تروى بها

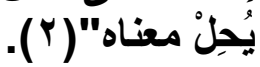

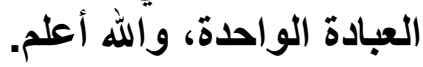

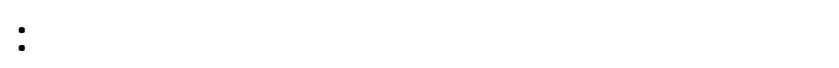
r ا - إنباع السئنة.

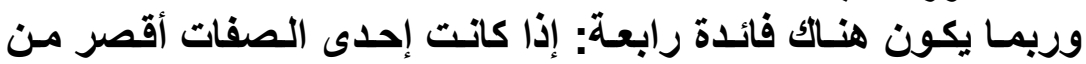

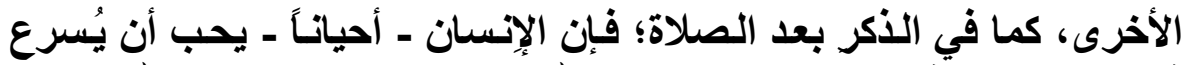

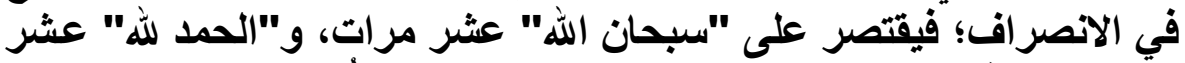

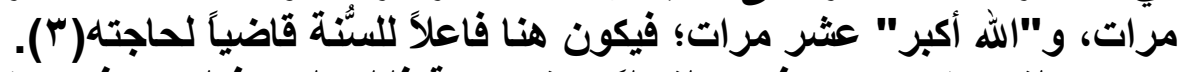

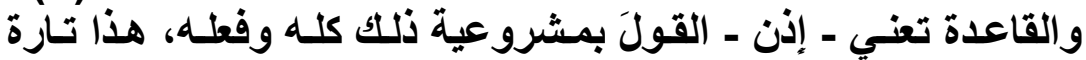

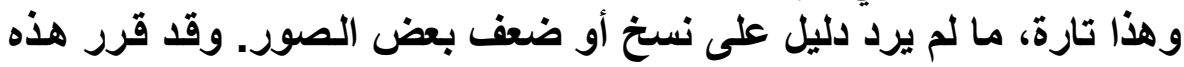

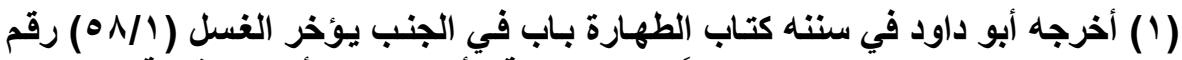

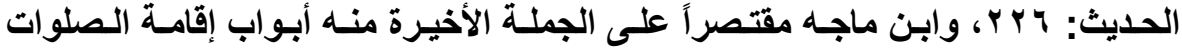

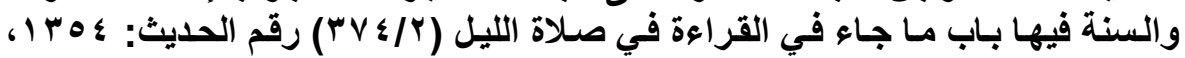

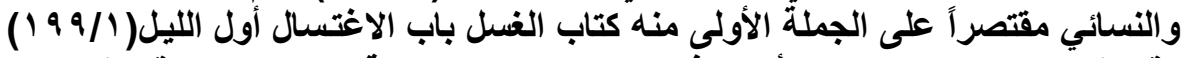

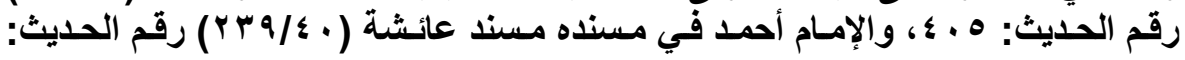

قال عنه الألباني: حديث صحيح.صحيح سنن أبي داود ( ( / ؛ ؛).

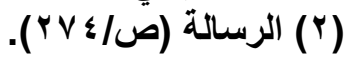

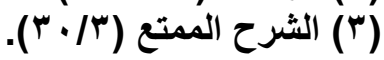


القاعدة شيخ الإسلام ابن تيمية وغيرُه من أهل العلم. المطلب الثالث

شروط العمل بالوجوه المتعددة اللعبادات

يشترط للعمل بالصفات المتعددة في أي عبادة عدة شـروط، يمكن

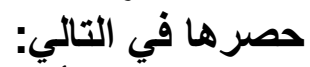

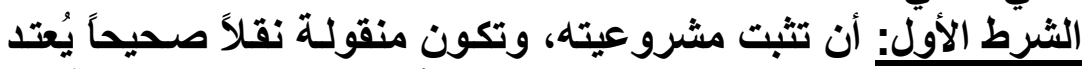

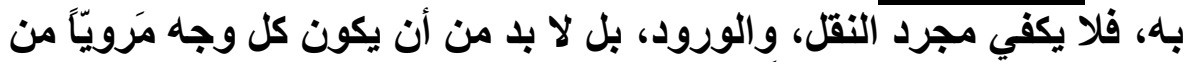

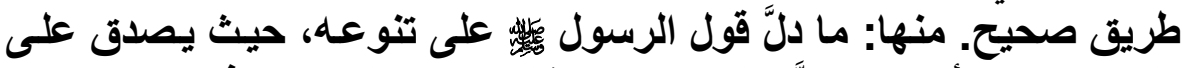

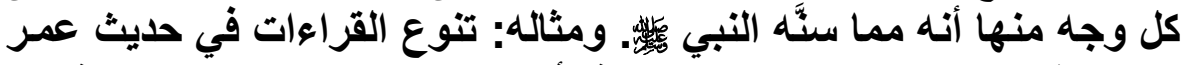

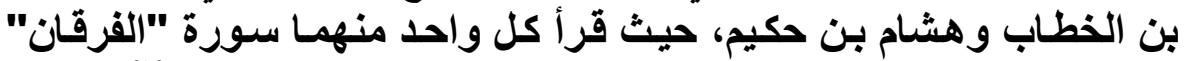

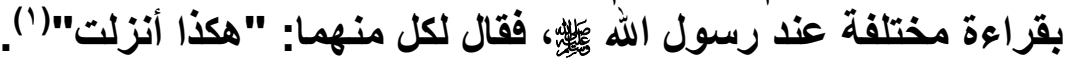

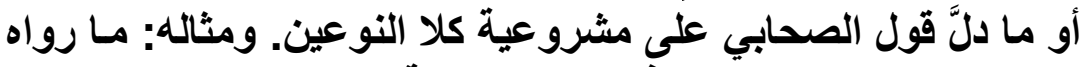

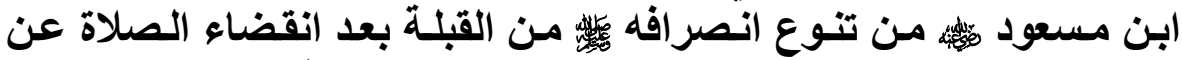

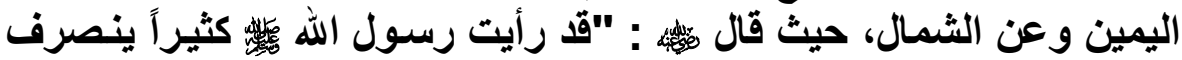

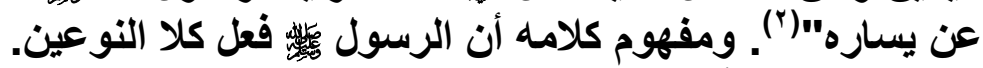

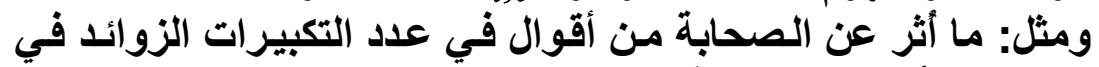

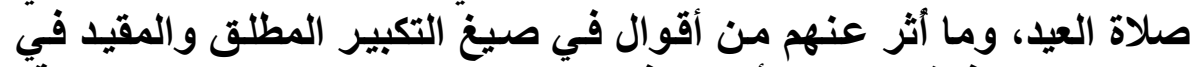

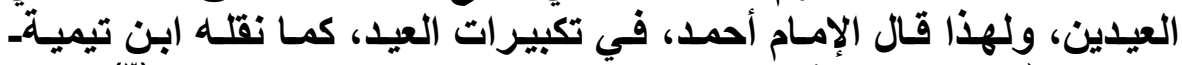

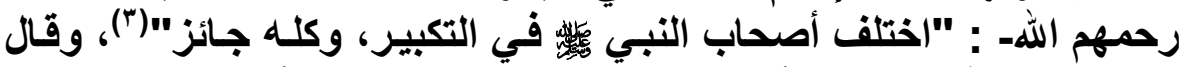
عنه ابن تيمية : "ومنها أنواع تكبيرات العيدي يجوز كل مأثور، وإن استحب لتهب

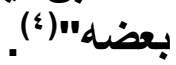

ونقل صاحب كثاف القتاع قول الإمام أحمد عن صفات صلاة الخوف:

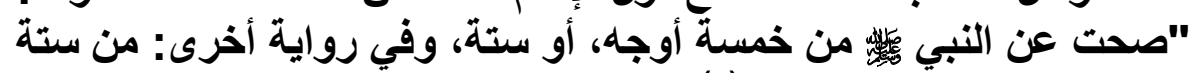

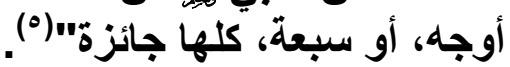

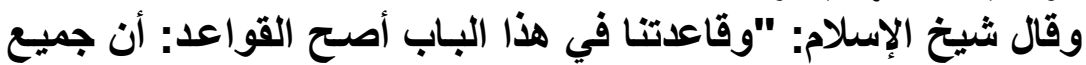

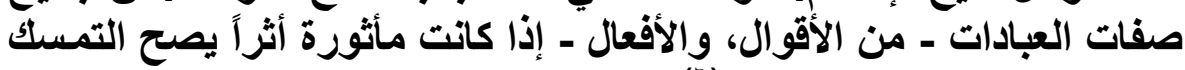

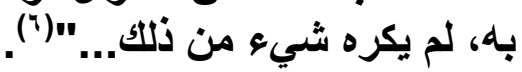

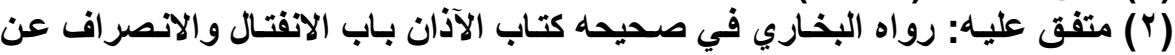

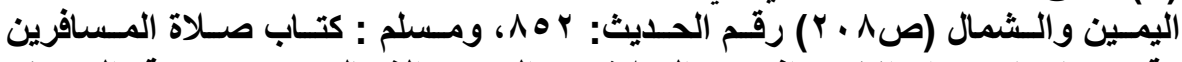

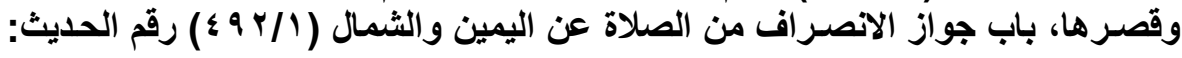

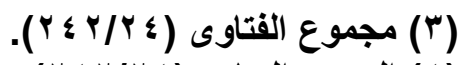

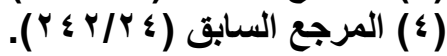

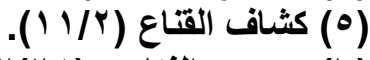

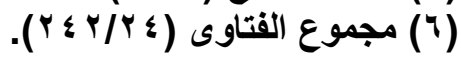


وعلى هذا فكل وجه نقل ولم يشبت، وجب اطراحـه، وعدم الاعتداد بـه

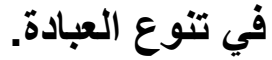

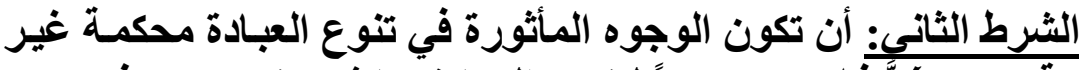

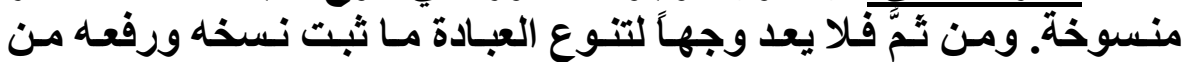

(الأحكام (')

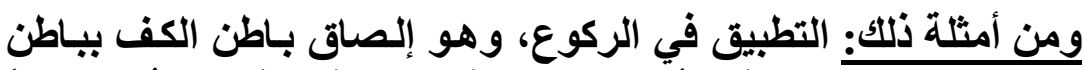

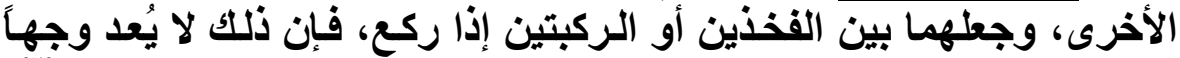

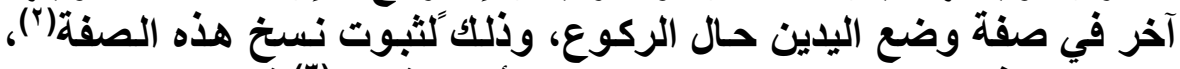

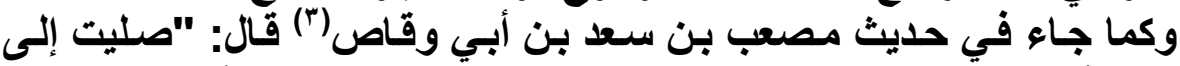

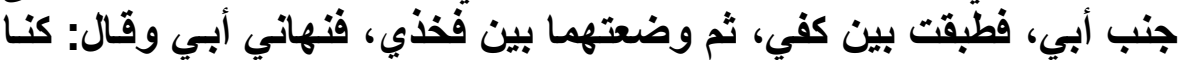

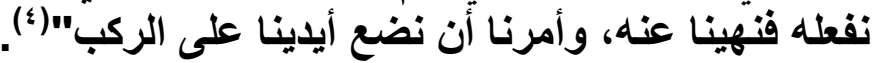

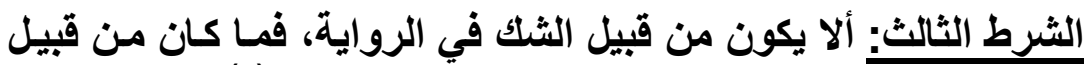

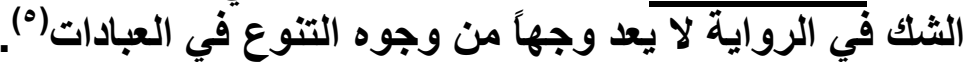

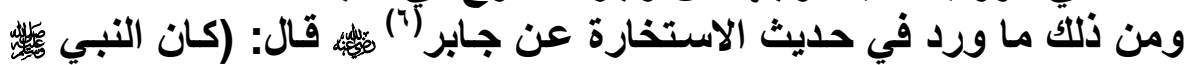

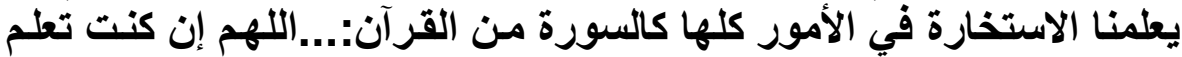

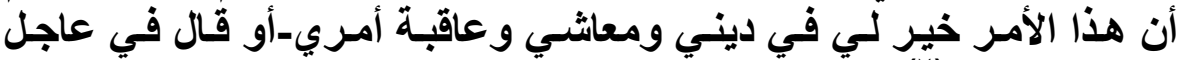

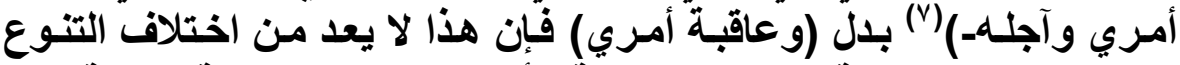

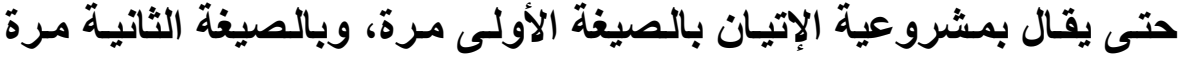

$$
\begin{aligned}
& \text { (1) ينظر: اختلاف التنوع (ص •r (I). }
\end{aligned}
$$

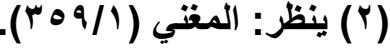

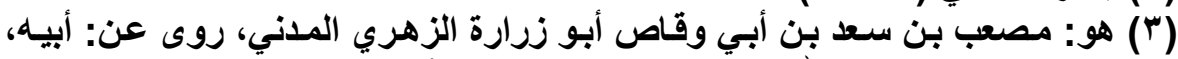

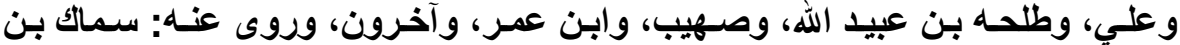

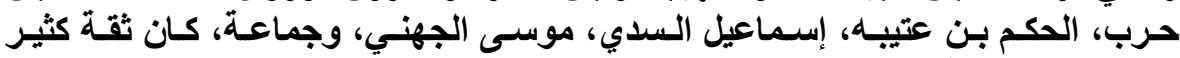

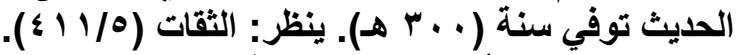

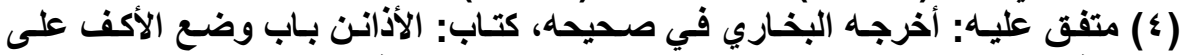

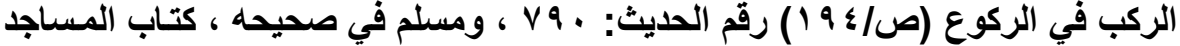

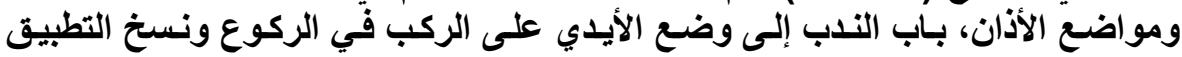

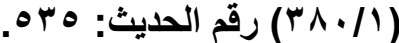

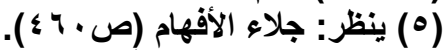

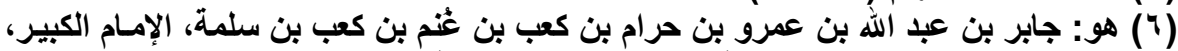

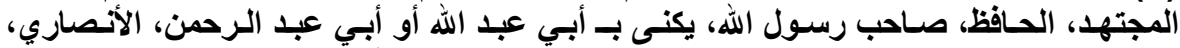

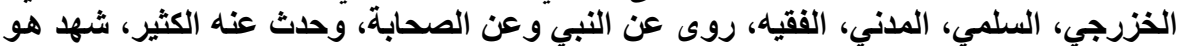

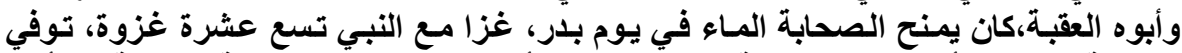

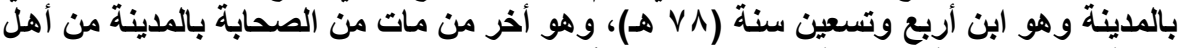

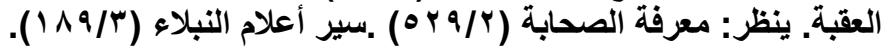

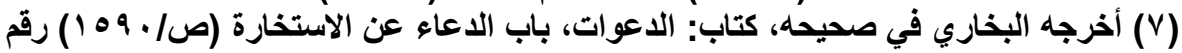

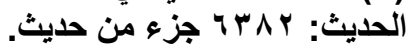


أخرى؛ لأن الصحيح من الصيغتين الصيغة الأولى، وهي قولـه: (وعاقبـة

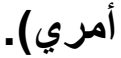

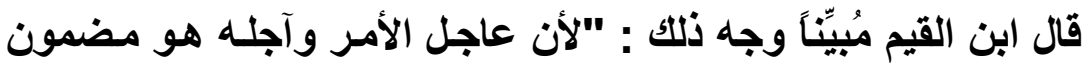

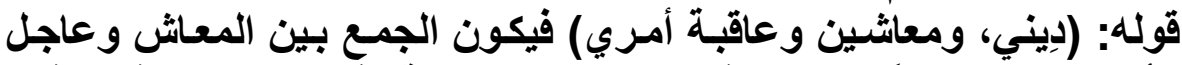

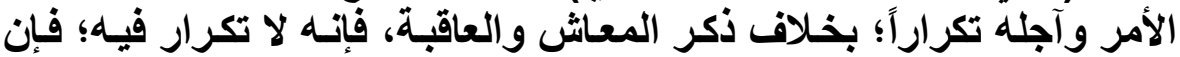
المعاش هو عاجل الأمر، والعاقبة آجله" (').

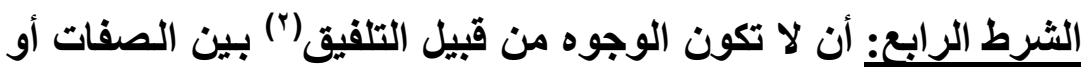

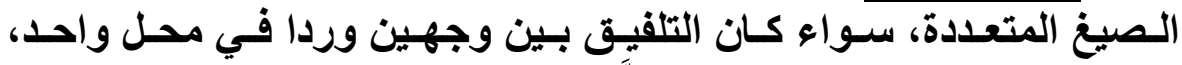

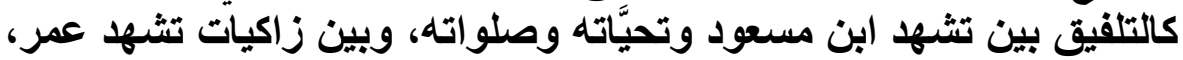

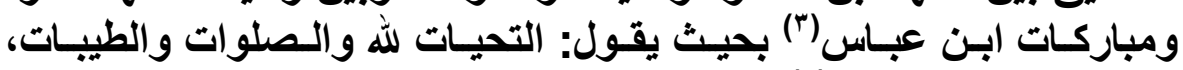

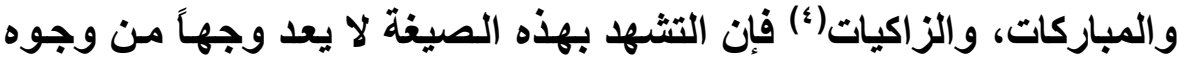
التنوع المشروع، وإن كانت مفردات هذه الصيغة وجملها ثابتة عن التبي

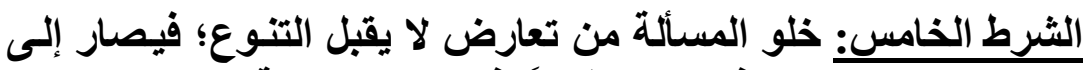

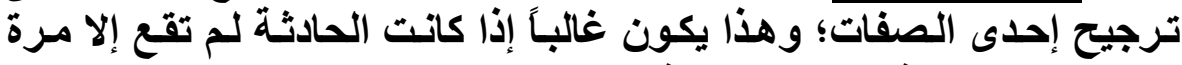

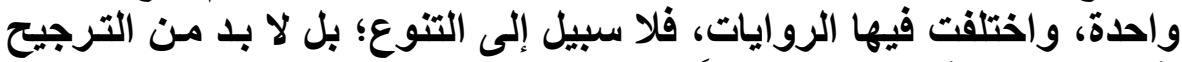

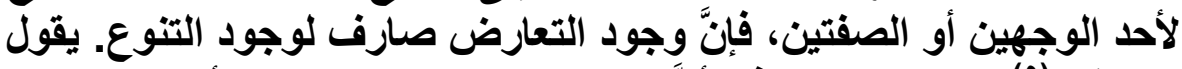

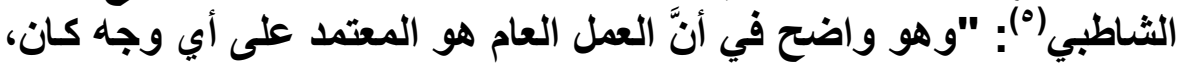

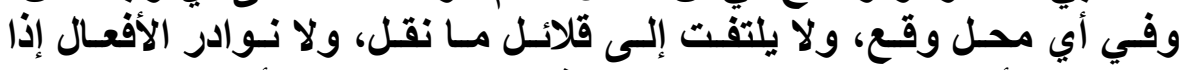

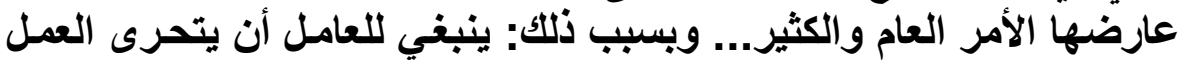

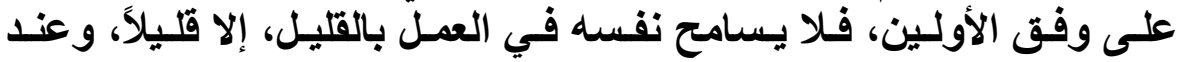

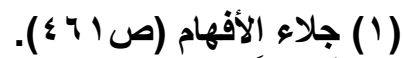

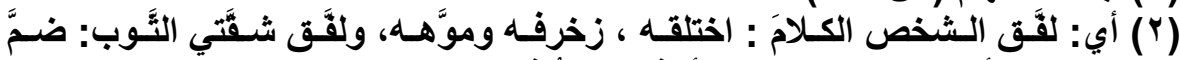

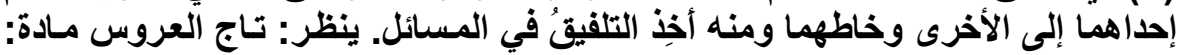

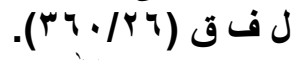

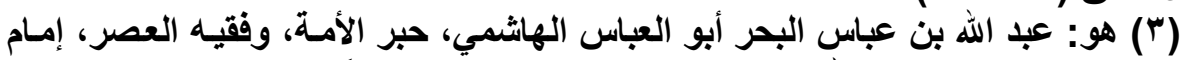

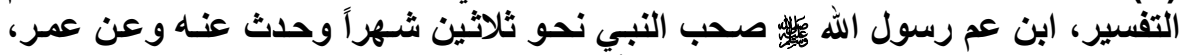

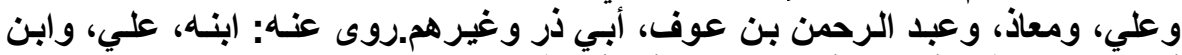

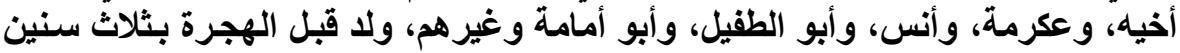

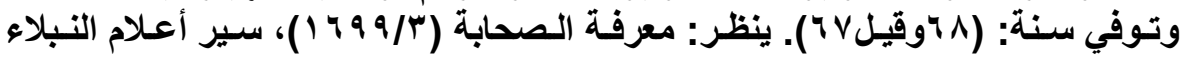

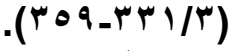

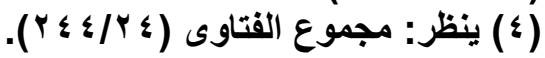

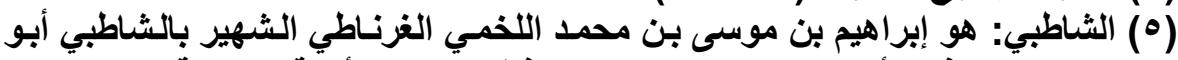

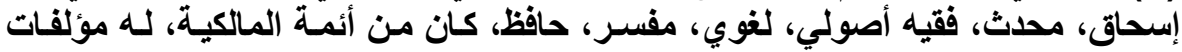

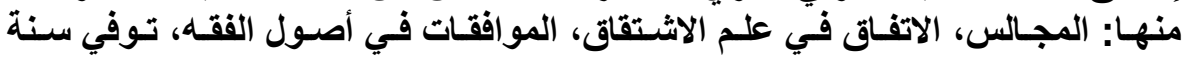

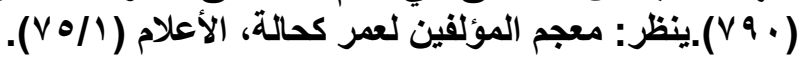




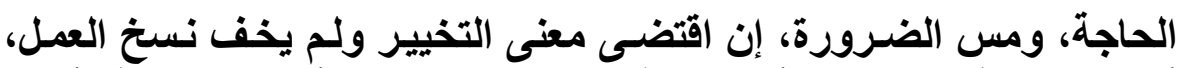

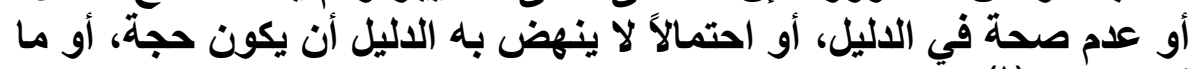
أشبه ذلك" (1) - (1) 


\section{المبمث الثاني}

\section{هموقف الفقهاء هن العبادات الواردة}

$$
\text { على وجوه متعددة، وأثر التنوع }
$$

م ق لفقها م لعبا J J ل ج متع

م حي ل لتجح لتخيي

المطلب الثاني

موقف الفقهاء من العبادات الواردة على وجوه متعددة من حيث المداومة والجمع 


\section{المطلب الأول}

\section{موقف الفقهاء من العبادات الواردة على وجوه متعددة}

\section{من ميث الترجيج والتخيير}

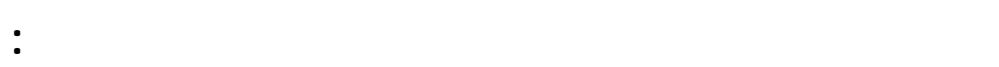

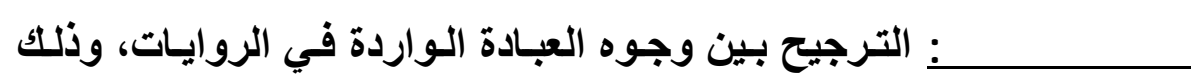

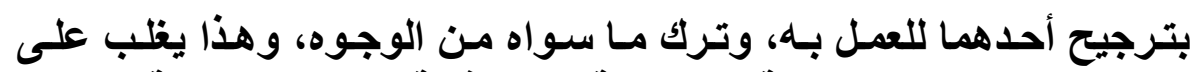

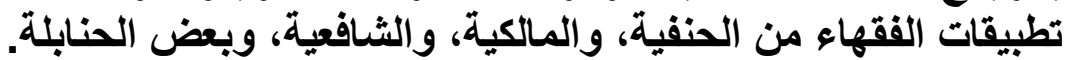

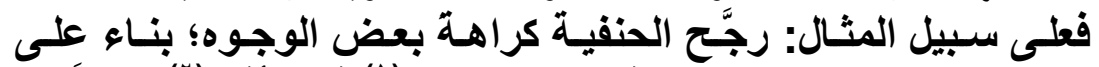

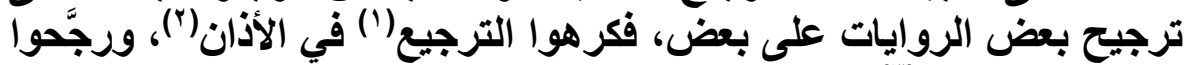

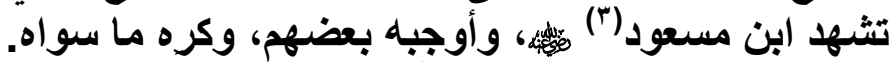

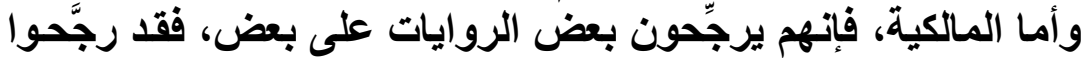

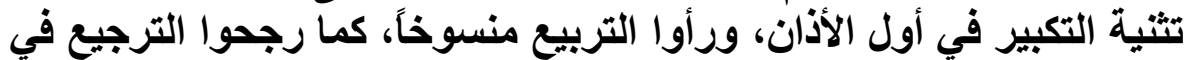

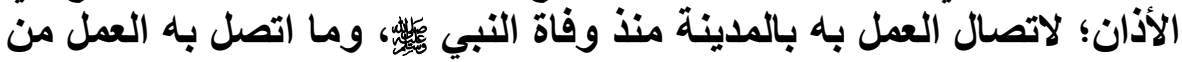

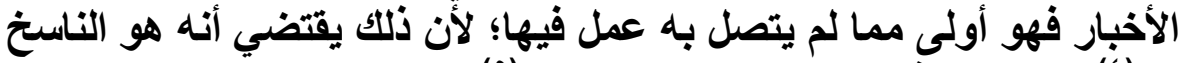

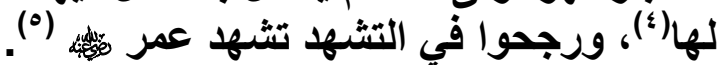

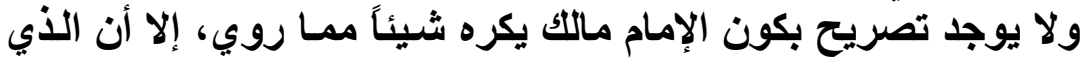

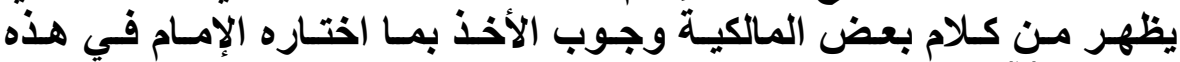

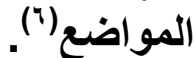

وأمسا الشافعية، فمـن أمثلـة الترجيح عندهم: ترجيحهم الترجيع في

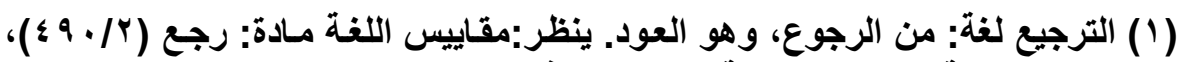

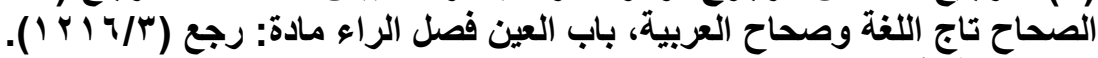

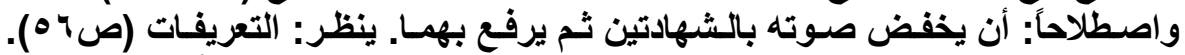

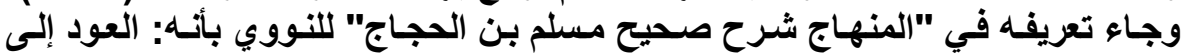

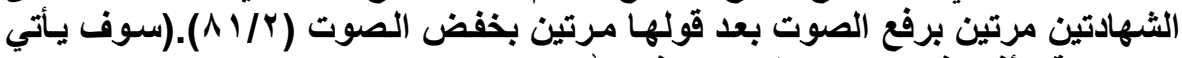

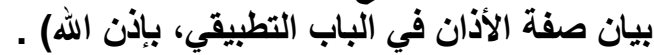

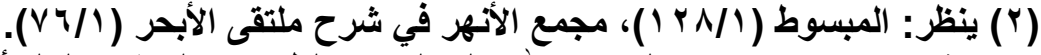

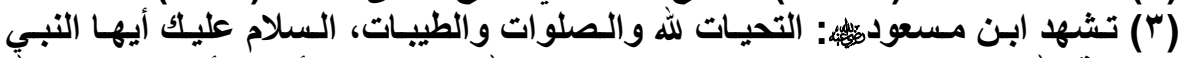

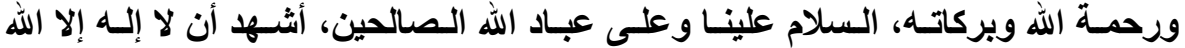

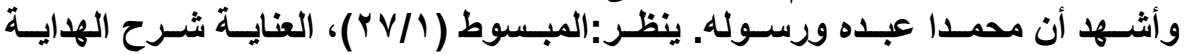

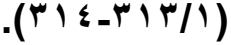

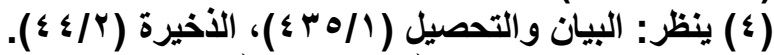

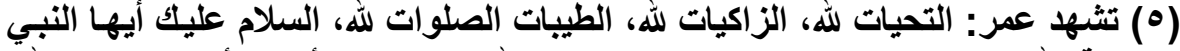

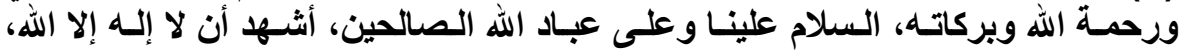

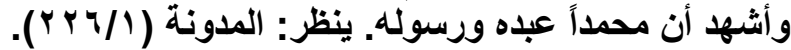
(T) ينظر: القو اعد والضوابط المتضمنة للتيسير ( ( / (T/1). 


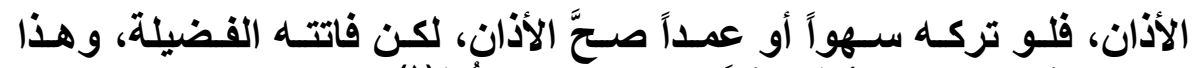

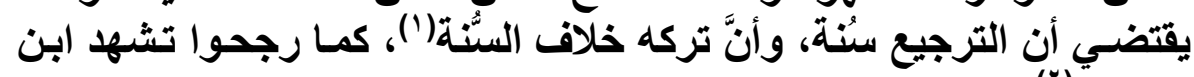

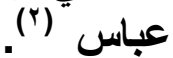
وأما الحنابلة: فرجحوا عدم الترجيع في الأذان، بل روي عن الإمسام

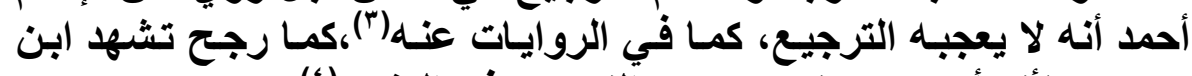

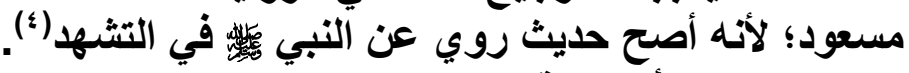
والإمام "أحمد" قد يرجح بعض التوجوه لَّبب ما، ولكنه لا يكره غيره

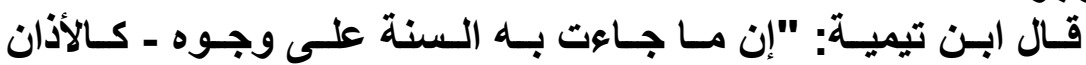

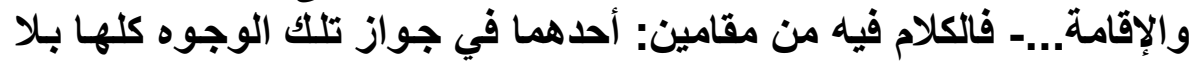

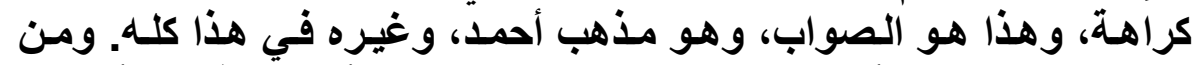

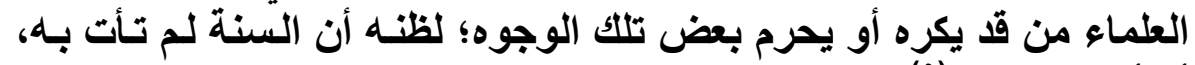

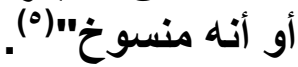

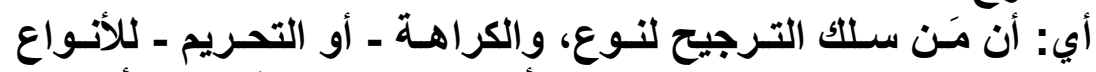
الأخرى، يكون إمـا بسبب دعوى النسخ، أو دعوى عدم الثبوت بالأحاديث

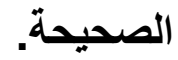

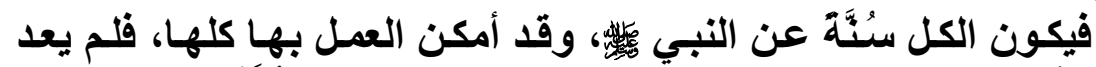

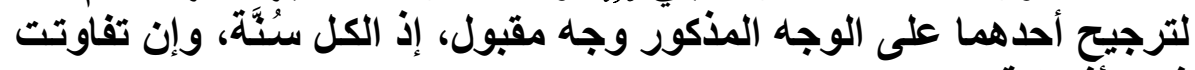

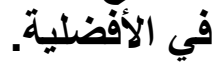

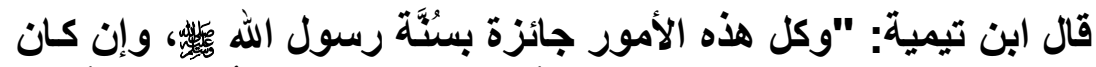

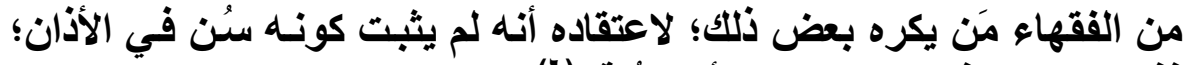

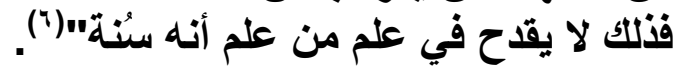

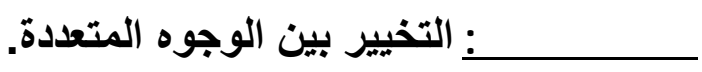

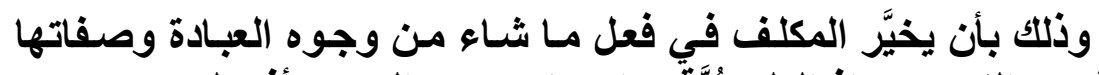

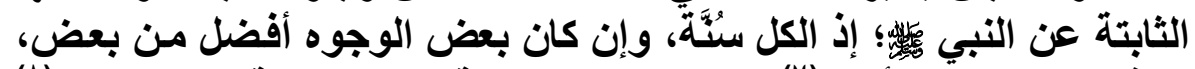

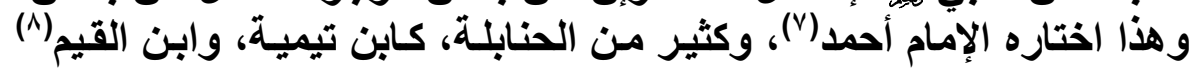

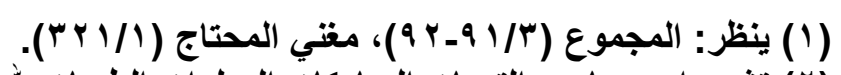

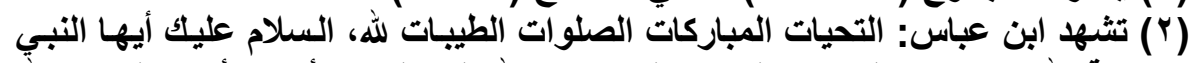

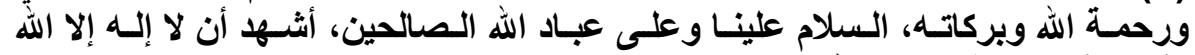

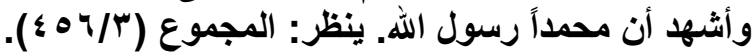

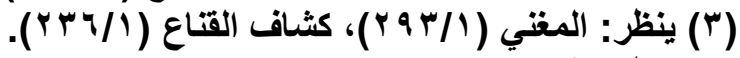

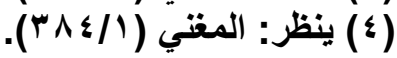

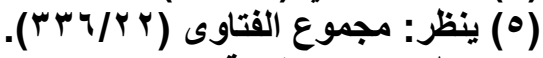

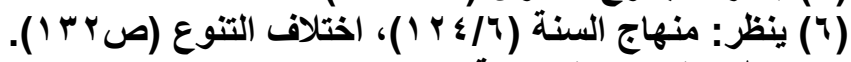

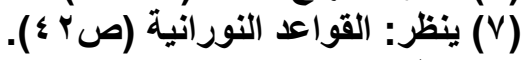

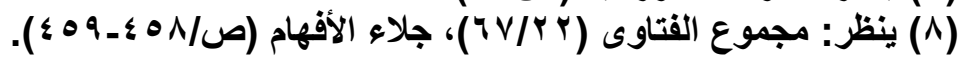


وغيرهم: قال شيخ الإسلام: "وأما الأذان - الذي هو شعار الإسـلام-فقد استعمل

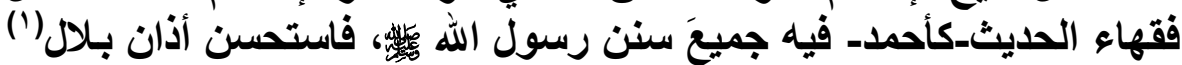

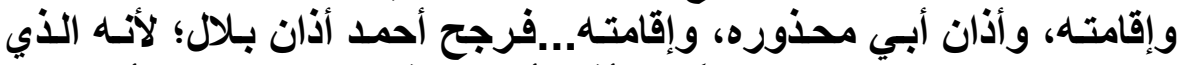

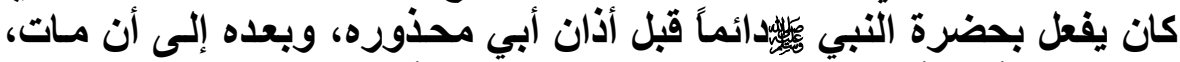

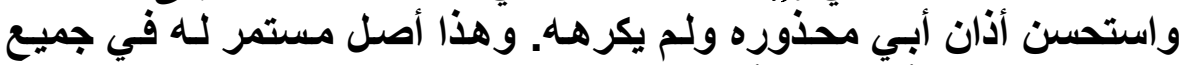

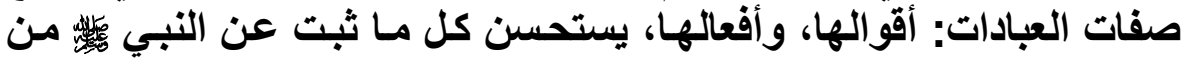

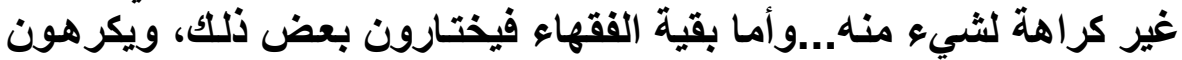

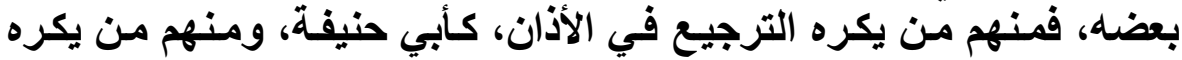

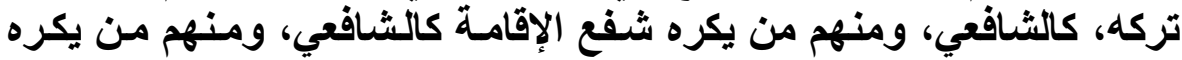

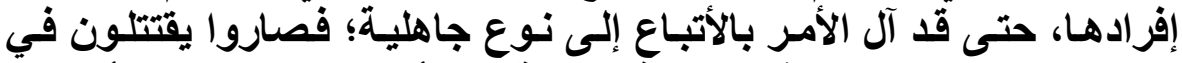

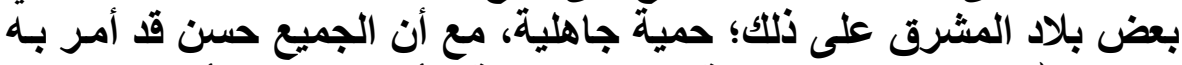

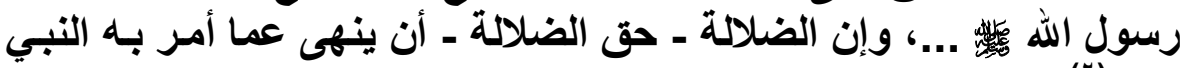
(r)"

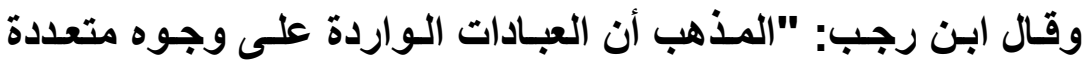

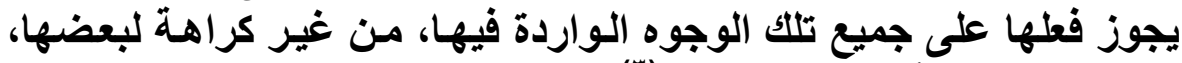

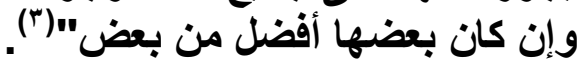

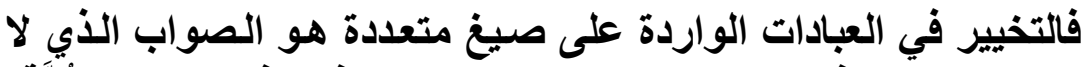

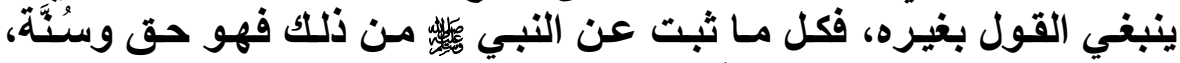

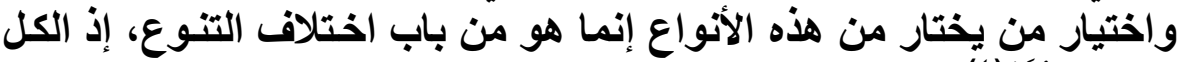

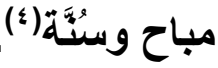

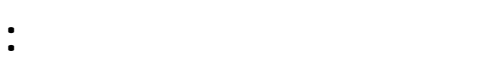

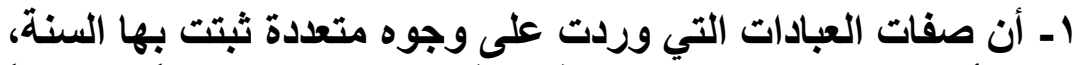

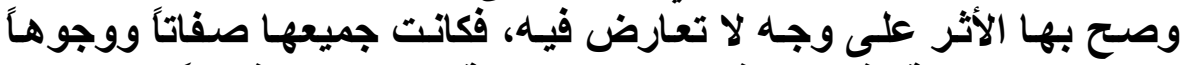

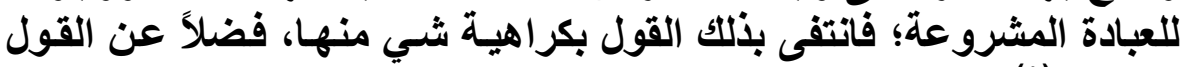

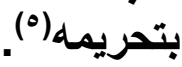
r- إن هذا التخيير يترتب على القول به التوسعة على المكلف في أمر

(1) هو: بلال بن رباح أبو عبد الله، وقيل: أبو عمرو، وقيل: أبو عبد الكريم، اسم أمسه :

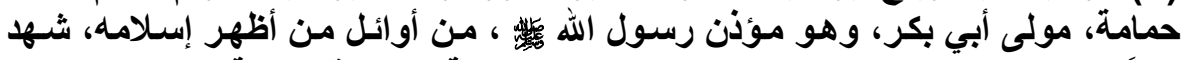

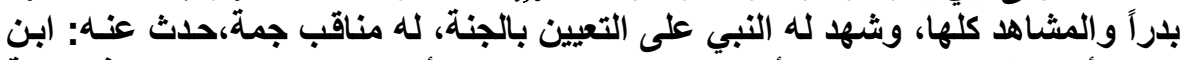

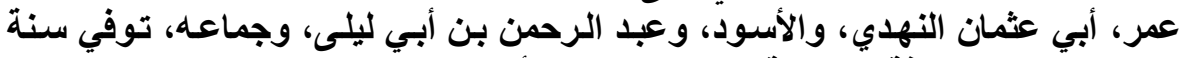

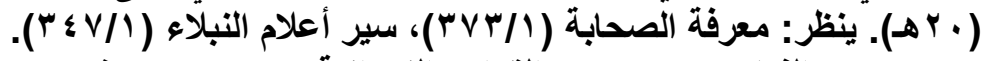

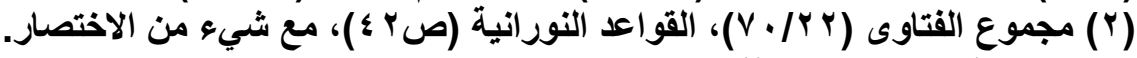

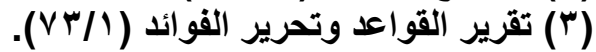

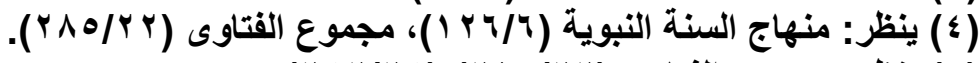

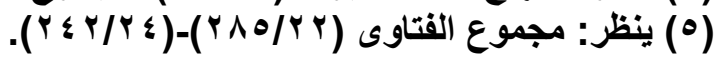


وستَّع الثارع فيه، بخلاف الترجيح؛ ففيه قدر من التضييق لا يخفى (').

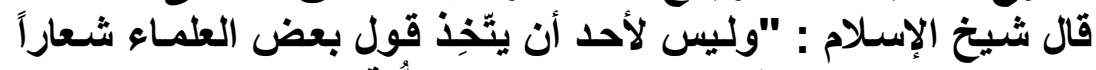

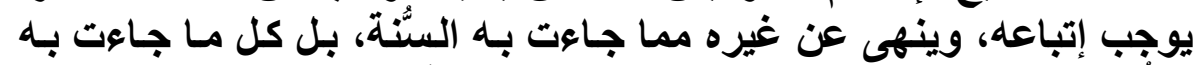

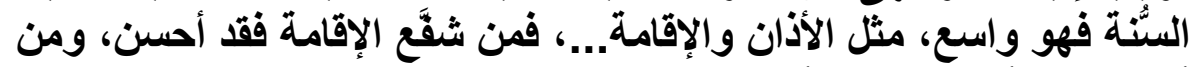

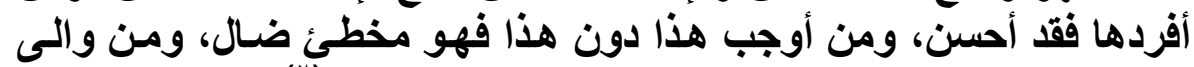

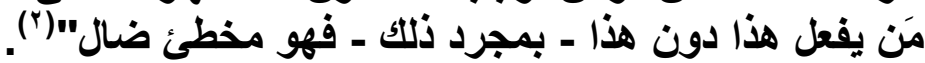

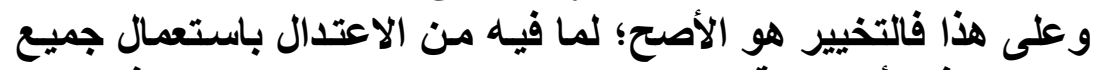

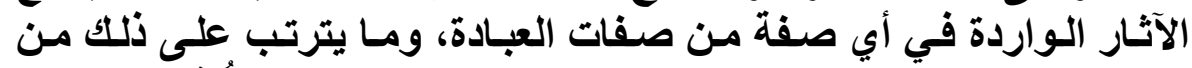

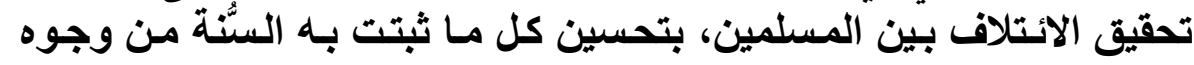

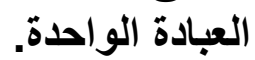

\section{المطالب النانبي}

\section{موقف الفقهاء من العبادات الواردة على وجوه متهددة}

\section{من صيث المداومة والجمعر والنتنوبير}

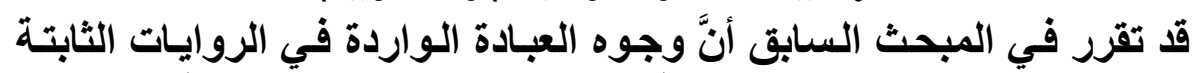

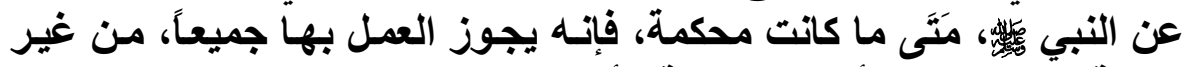

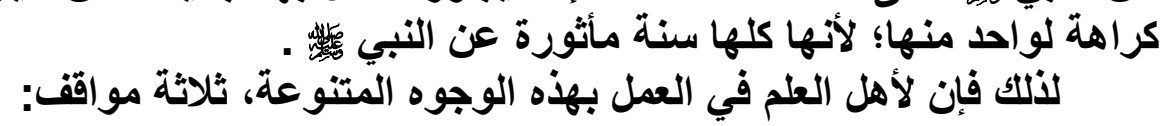
لم ق ألم

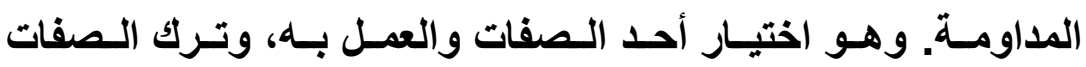

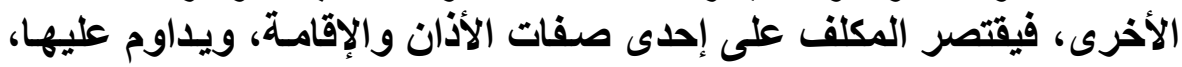

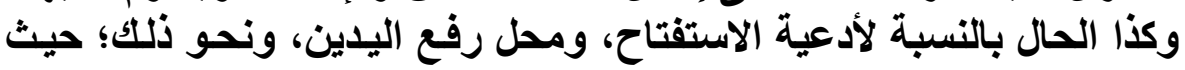

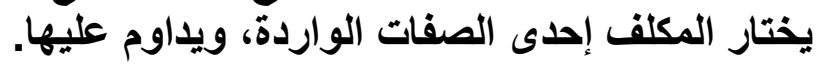

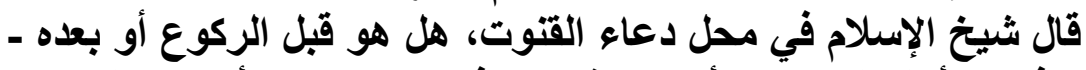

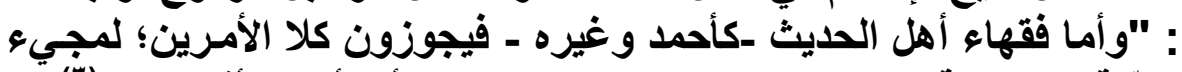

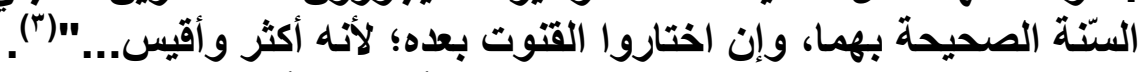

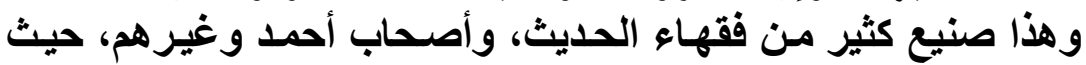

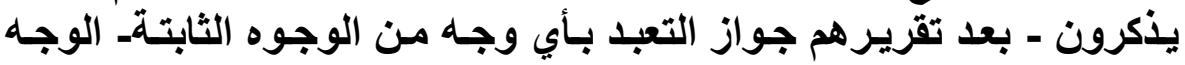

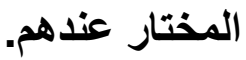

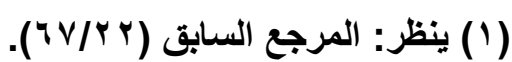

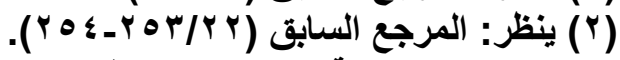

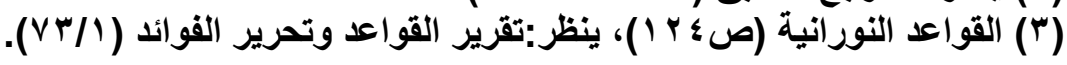


وعُمدةُ من سلك المداومة على العبادة من الفقهاء: اعتقاد أفضلية ذلتك

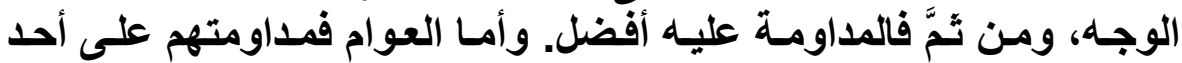

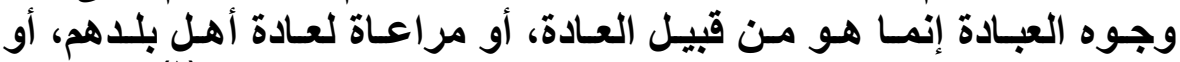

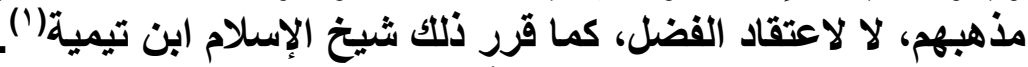

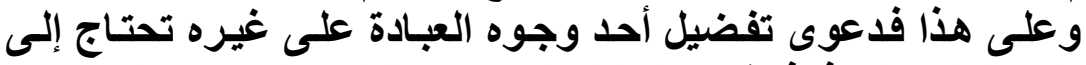

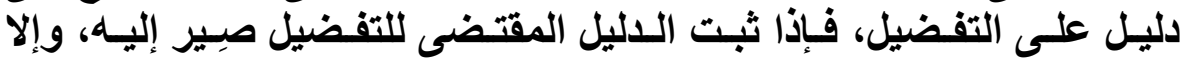

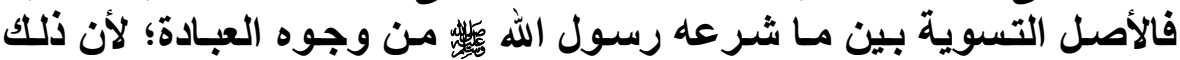

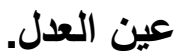
قال ابن تيمية: "إن في المداومة على نوع دون غيره هجرانه فئ لبعض

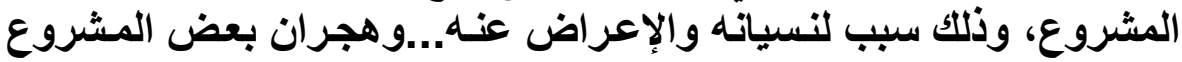

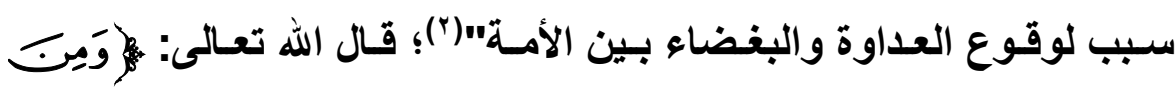

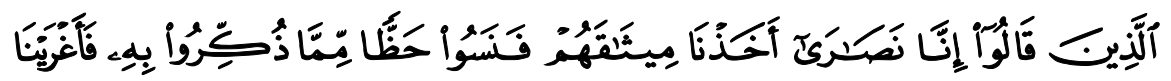

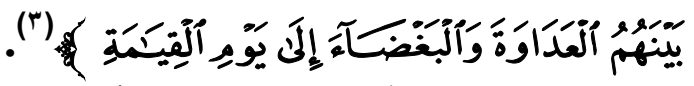

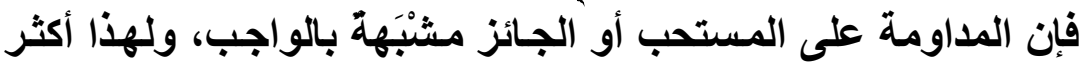

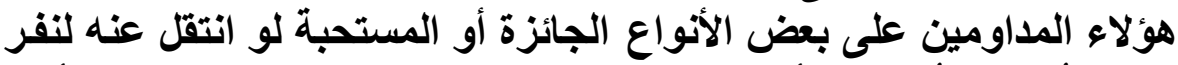

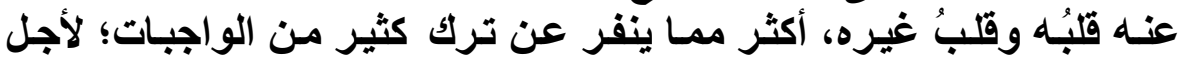

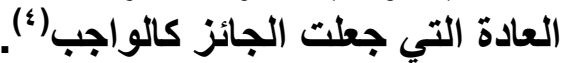

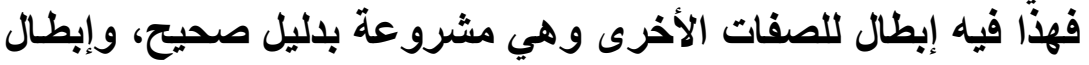
وإنكار شيء من الشرع لا يجوز.

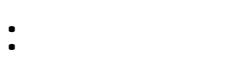

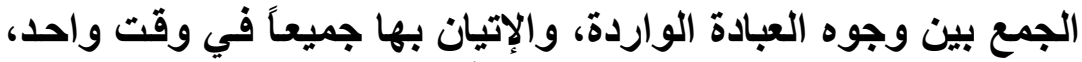

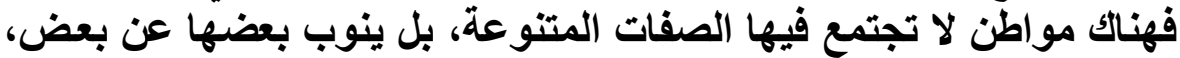

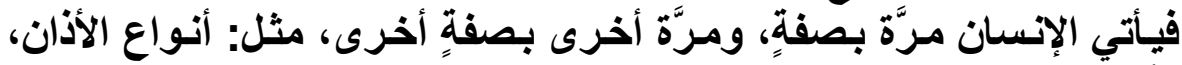

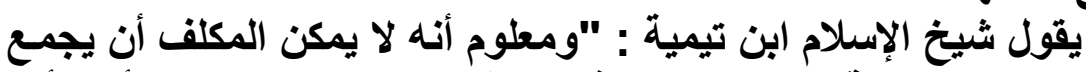

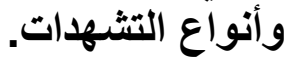

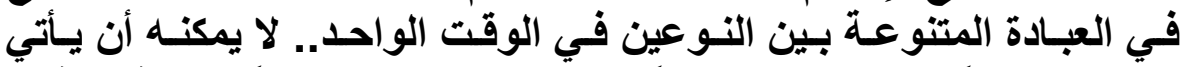

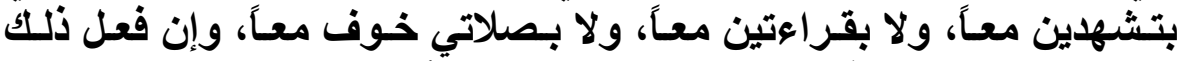

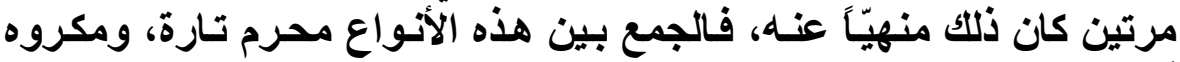

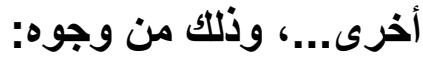

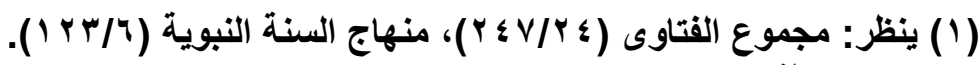

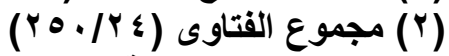

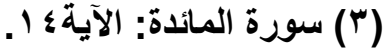

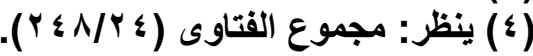




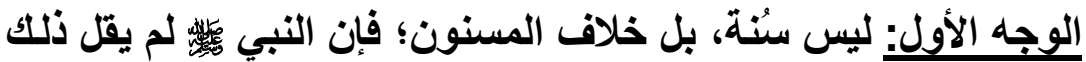

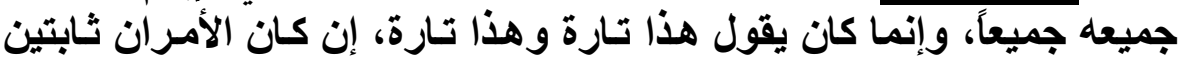

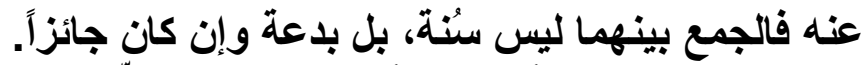

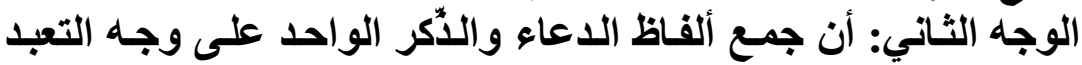

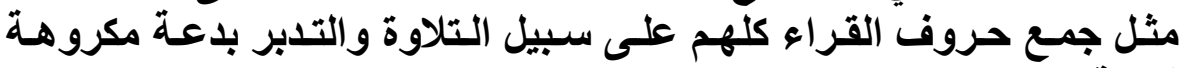
قبيحة، إلا على سبيل الدرس والحفئ.

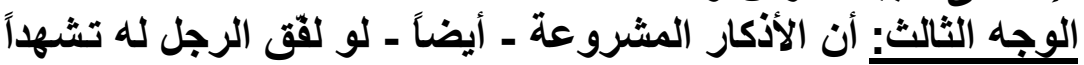

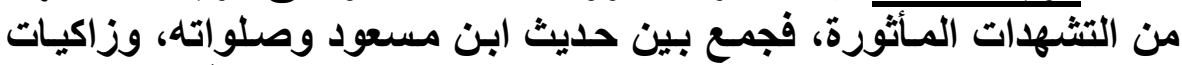

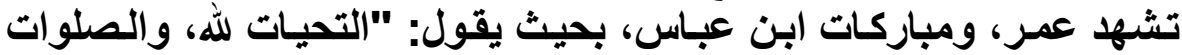

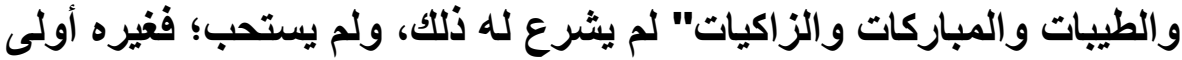

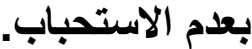

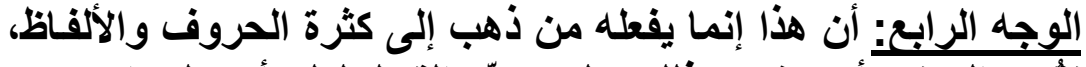

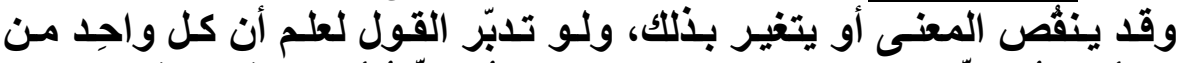

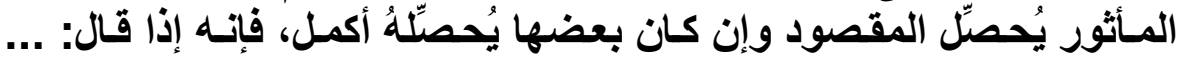

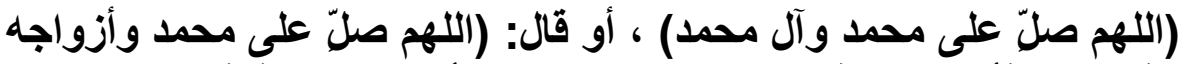

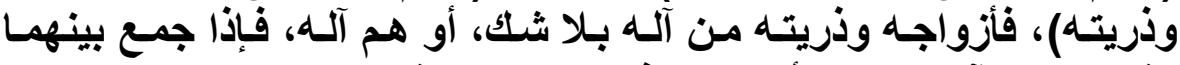

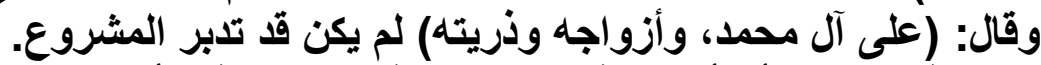

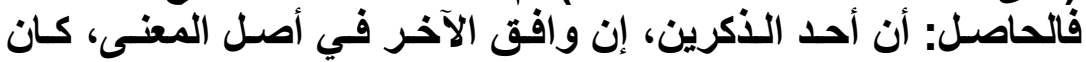

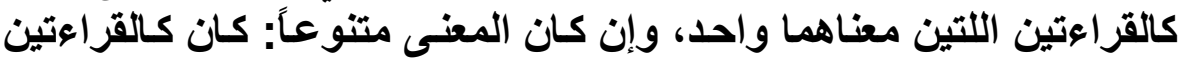

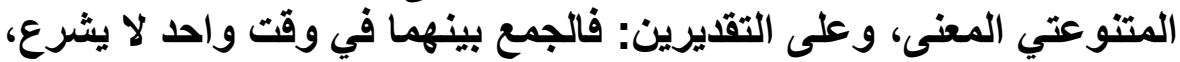

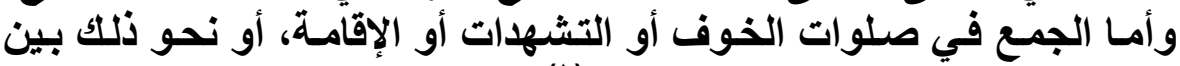

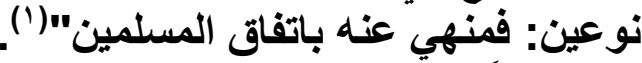

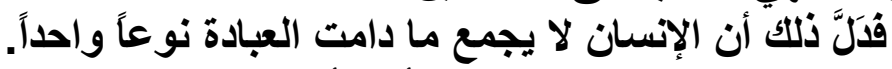

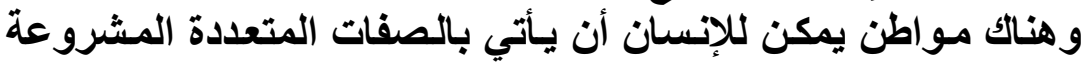

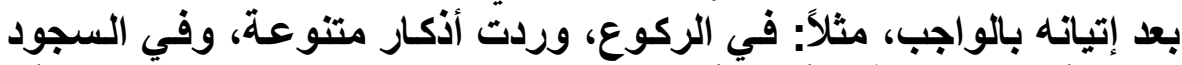

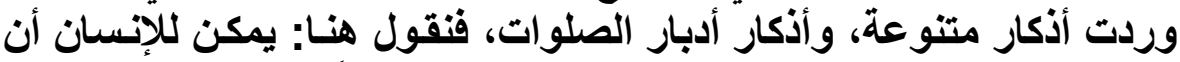

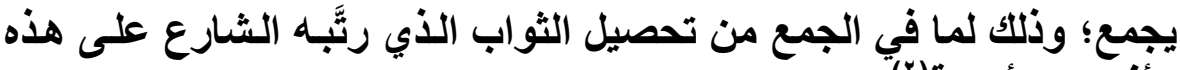
الأذكار والأدعية) (ب).

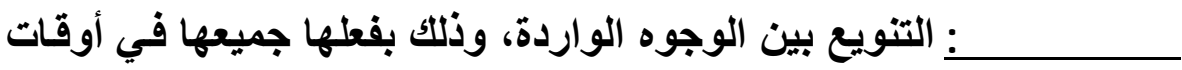

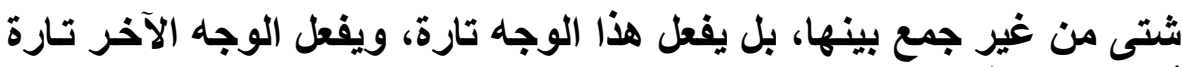
أخرى، وهكذا. 
وقد قرر ذلك شيخ الإسـلام ابن تيمية حيث قال :" وقاعدتنا في هذا

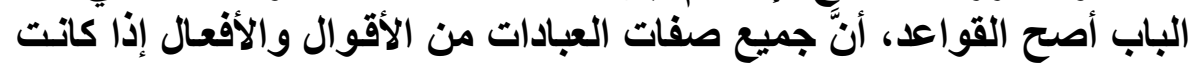

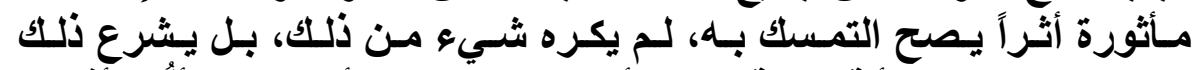

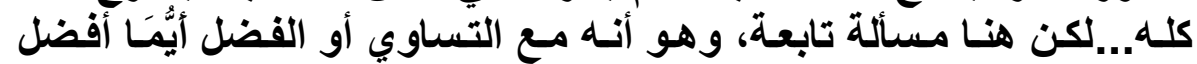

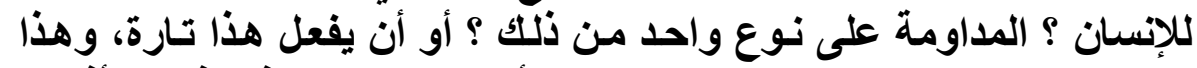

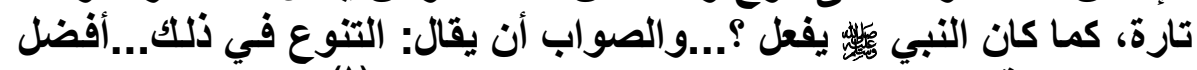

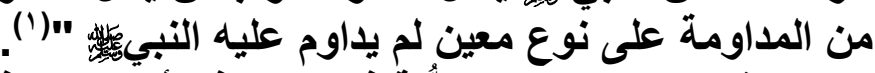

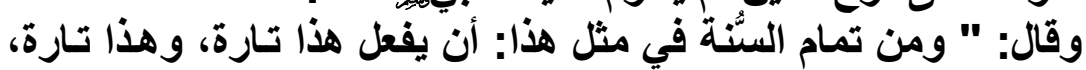

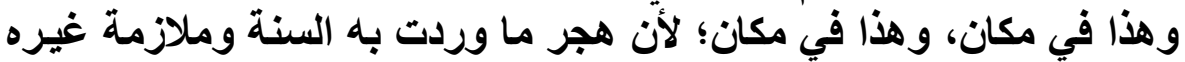

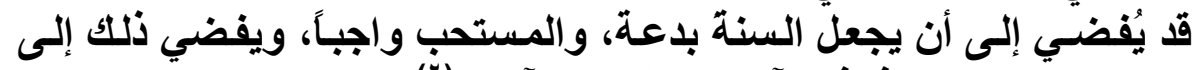

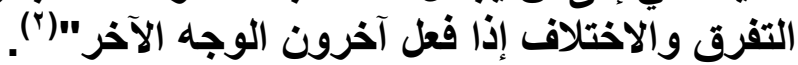

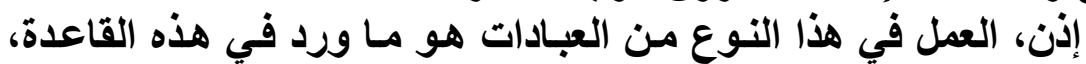

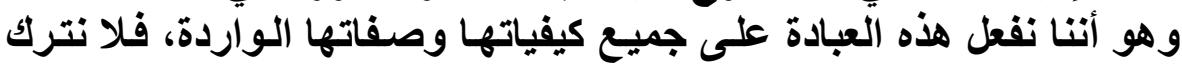

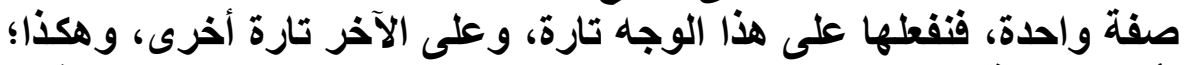

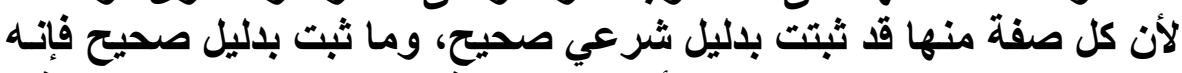

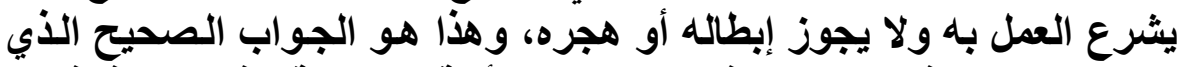

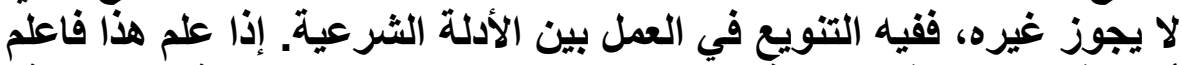

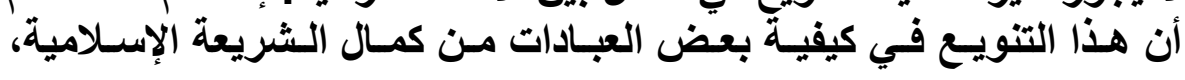

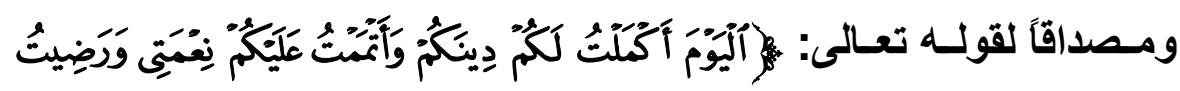

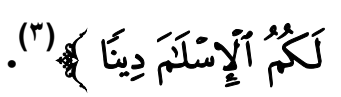

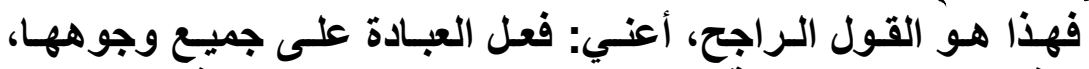

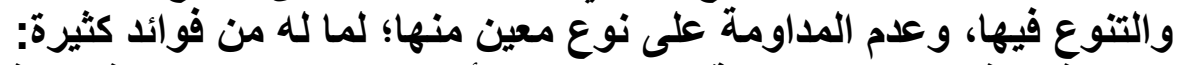

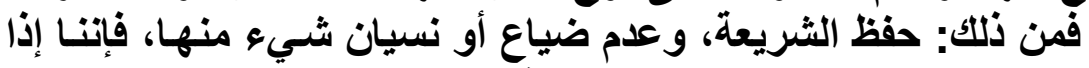

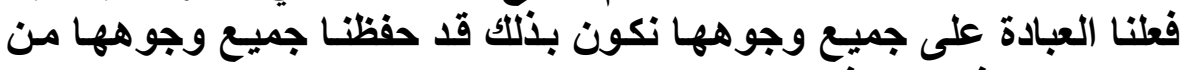

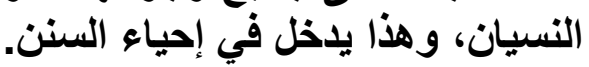

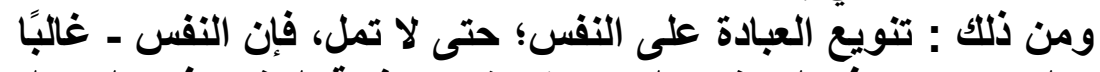

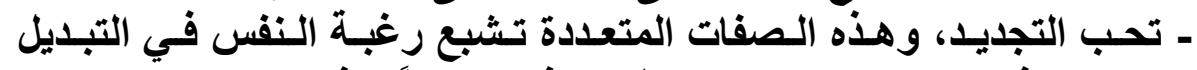

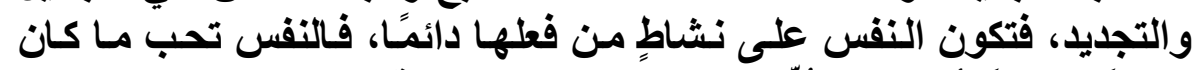

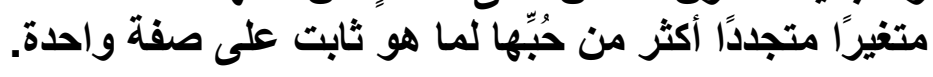




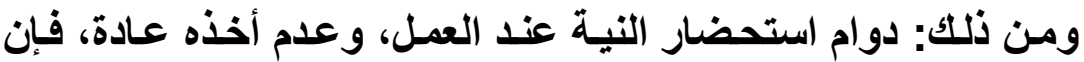

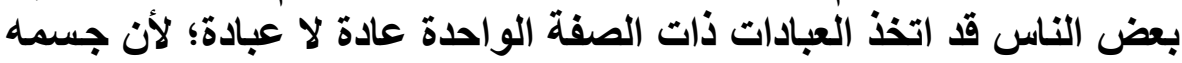

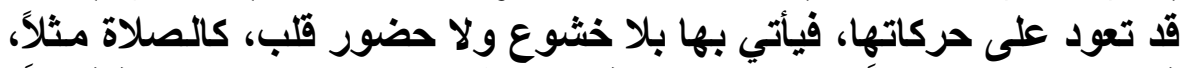

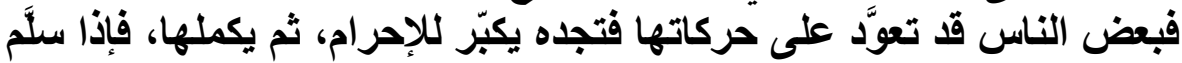

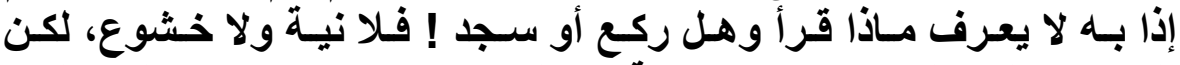

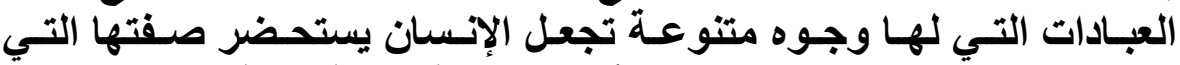

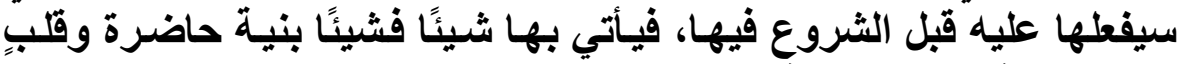

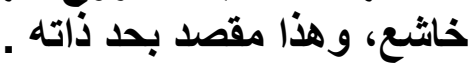




\section{المبمث الثالث \\ الجانب التطبيقي}

عبادات واردة على وجوه متعددة

في الطهارة والصلاة

المطلب الأول

عبادات واردة على وجوه متعددة في الطهارة

لف لف لأ ل

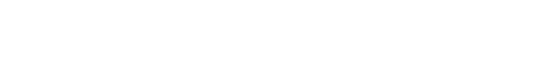

عبا

فيه ثلا مسائل:

لمسألة لأ له

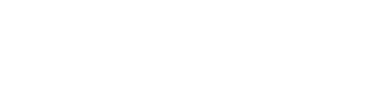

جاء عن النبي

مرتين مرتين، وورد ثلاث مرات أنهات.

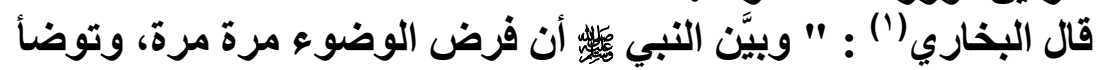

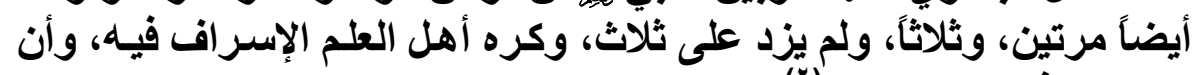

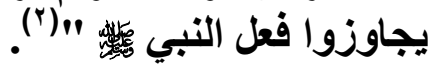

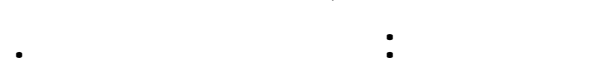

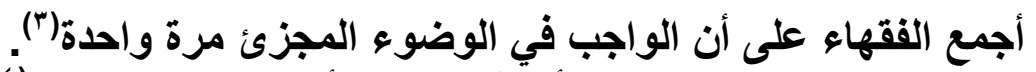

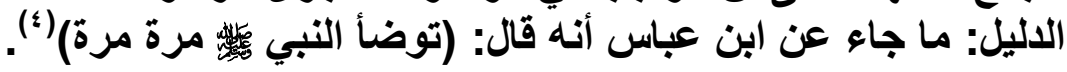

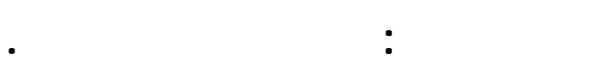

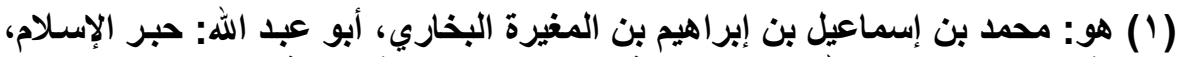

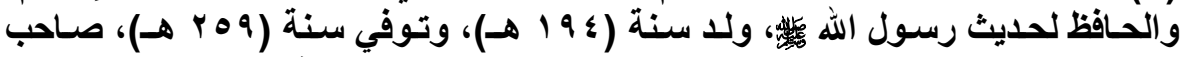

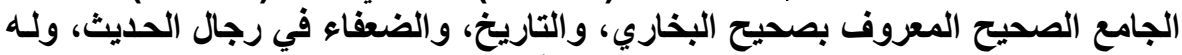

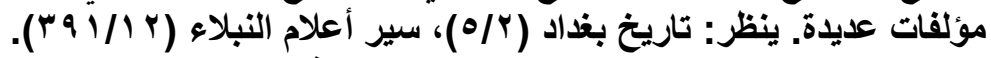

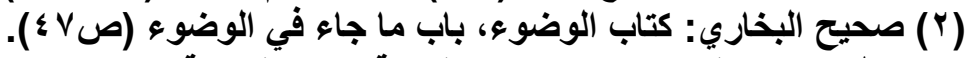

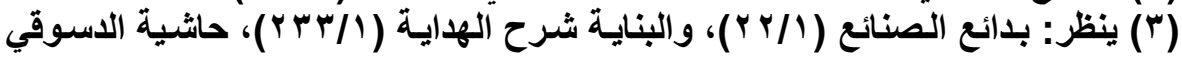

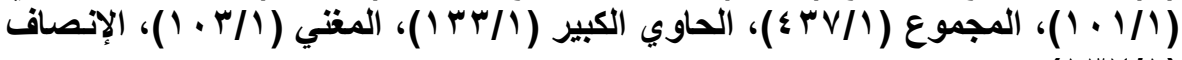

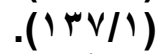
(؛) أخرجه البخاري في صحيحه : كتاب الوضوء، باب الوضوء مرة مرة (صبهه) رقم الحديث: أخرجه اليخاري 


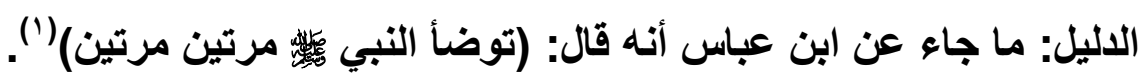

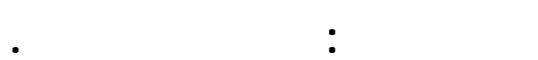

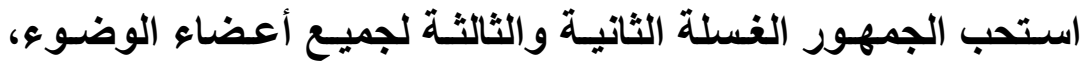

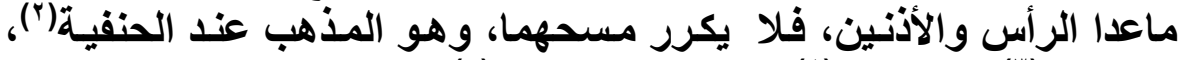

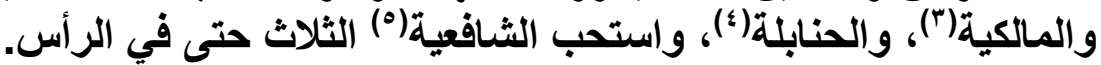

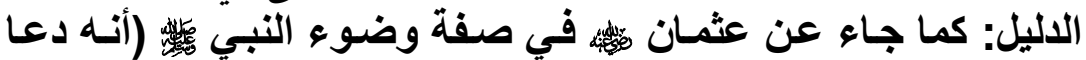

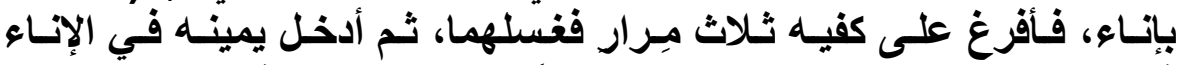

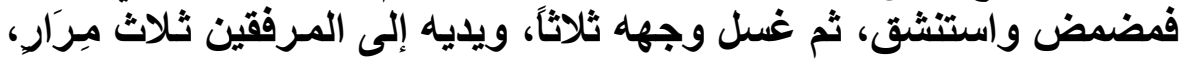

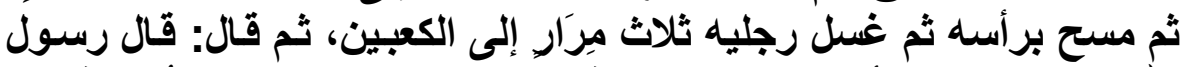

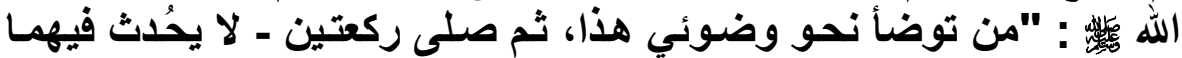

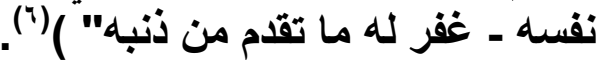

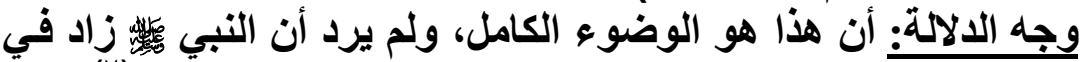

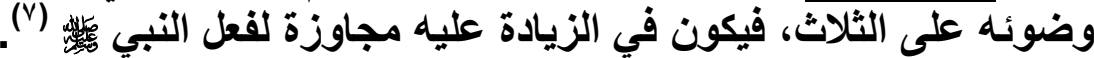

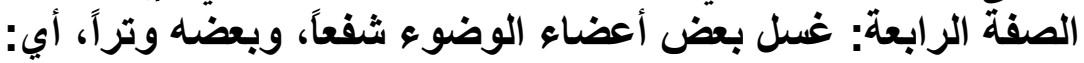

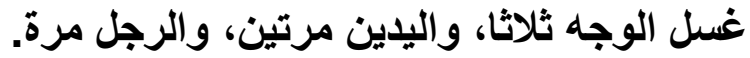
أجمع الفقهاء على جواز والئ المخالفة بين الأعضاء، فئه فيغسل بعضها مرة،

وبعضها مرتين (^).

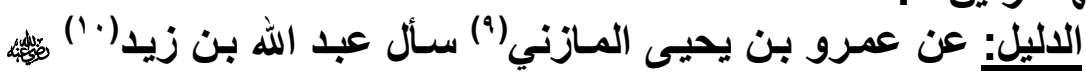

(1) أخرجه البخاري في صحيحه : كتاب الوضوء، باب الوضوء مرتين مرتين (ص به) رقم

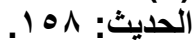

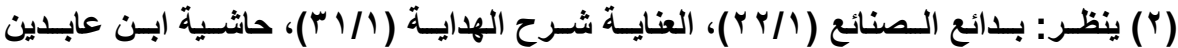

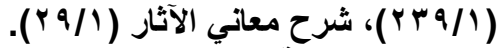

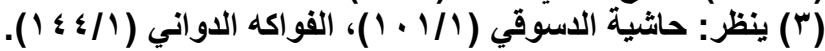

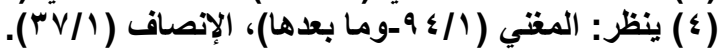

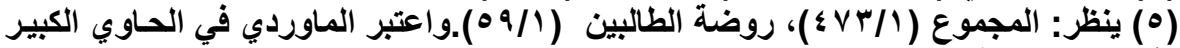

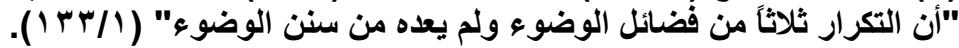

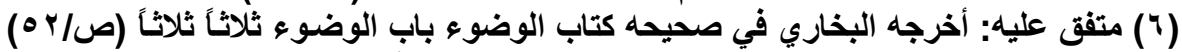

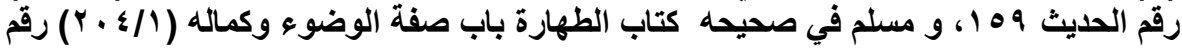

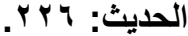

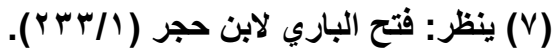

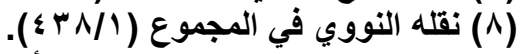

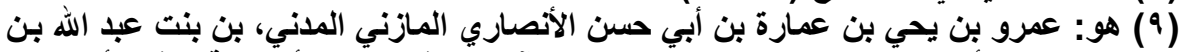

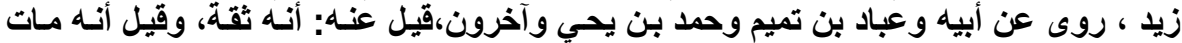

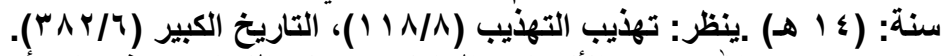

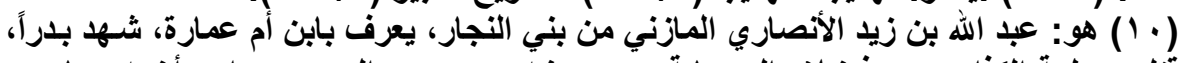

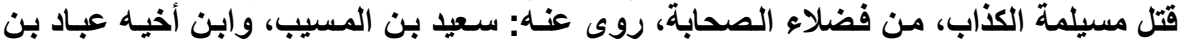

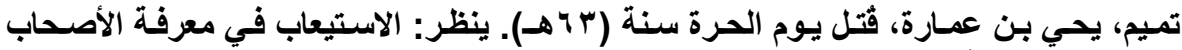
(T/T/T) 


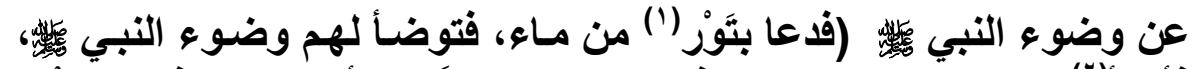

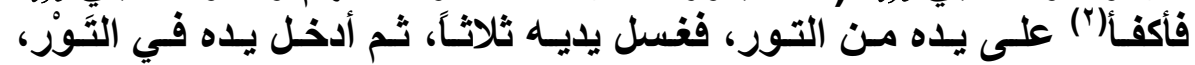

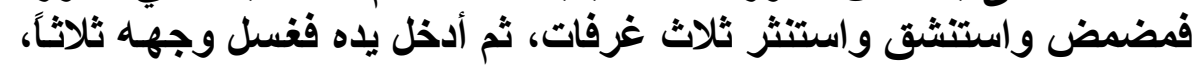

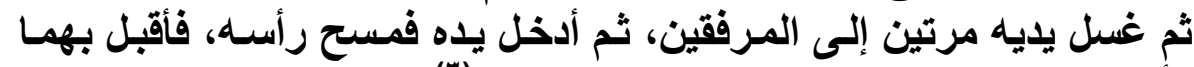

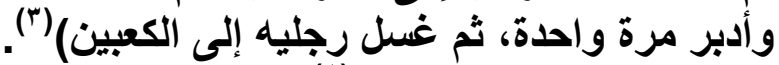

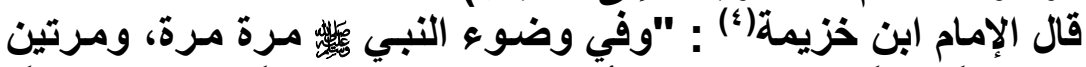

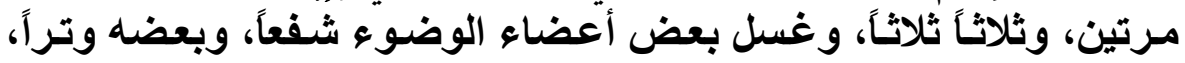

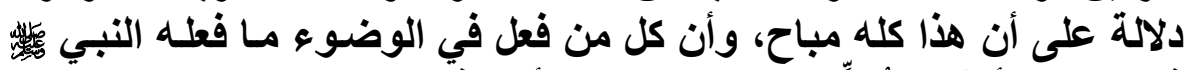

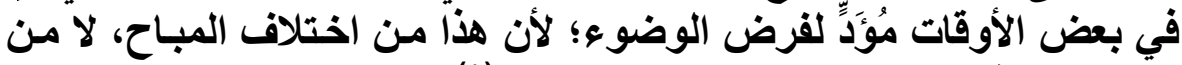

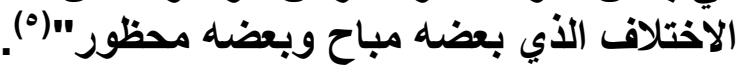

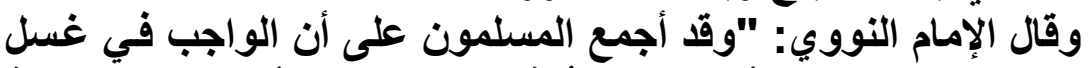

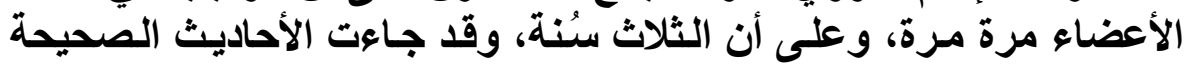

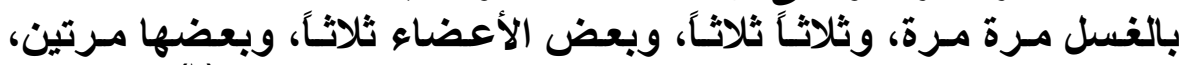

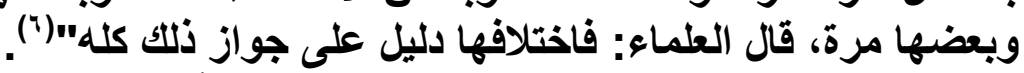

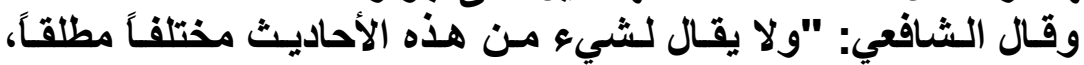

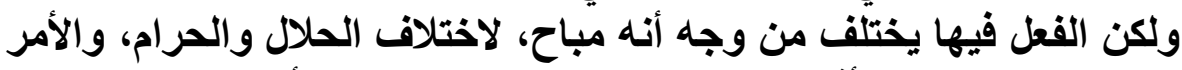

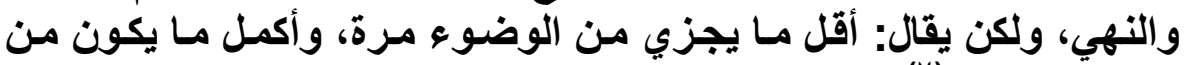

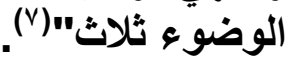
وقال الطحاوي(^) : "في هذه الأحاديث دليل أن المفترض من الوضوء

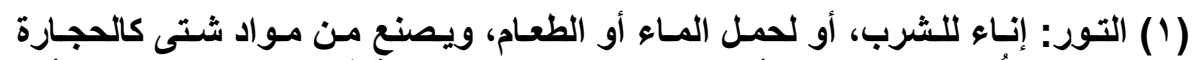

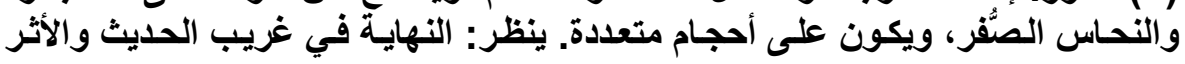

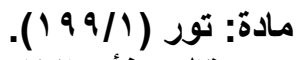
(Y) يقال: كفأت الإتاء، و أكفأته، إذا كبتهاه، وإذا أملته. ينظر: المرجع السابق مـادة: كفأ ( $(1 \wedge r / \varepsilon)$

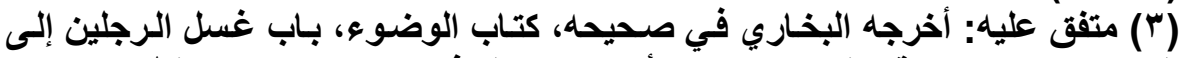

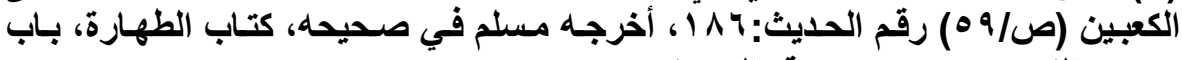

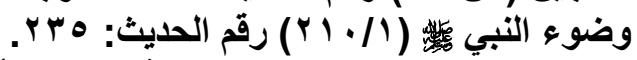

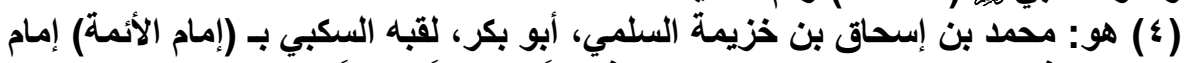

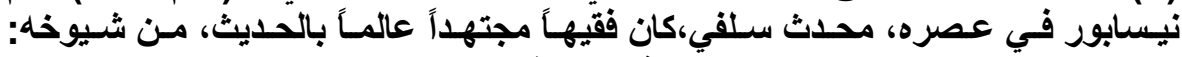

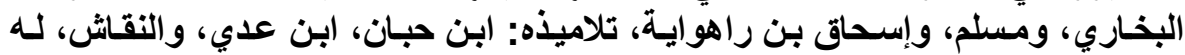

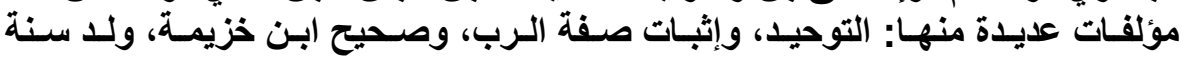

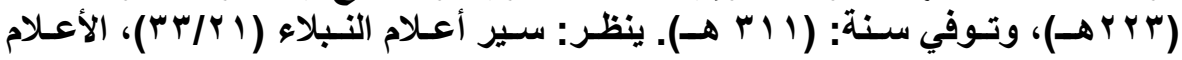

$$
\begin{aligned}
& \text { (0) صحيح ابن خزيمة ( إع ب ا ). }
\end{aligned}
$$

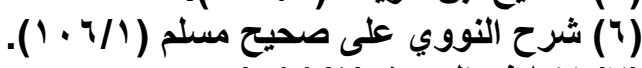

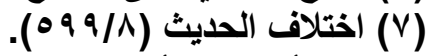

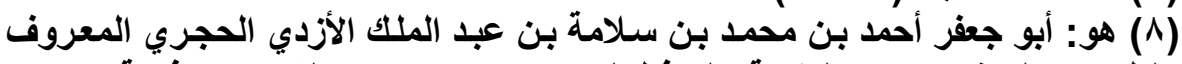

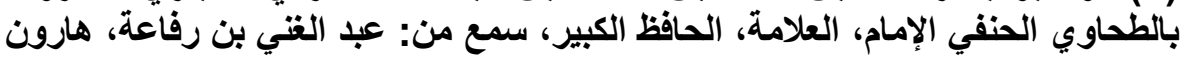


هو مرة مرة، وما زاد على ذلك فهو لإصابة الفضل لا الفرض، وفأ وأن المرتين

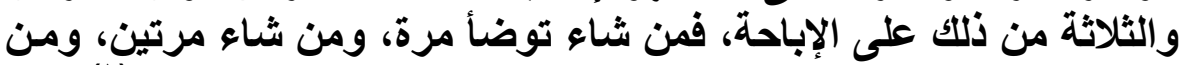

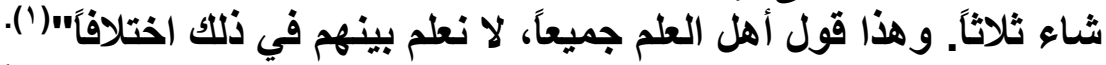

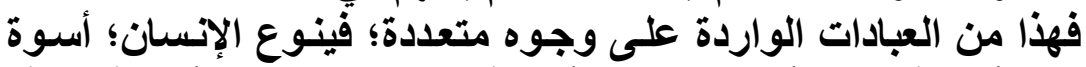

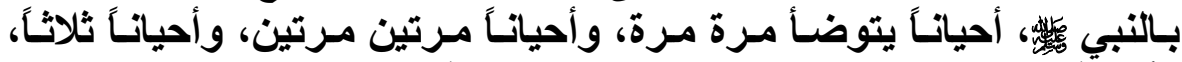

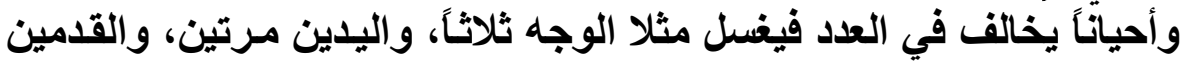

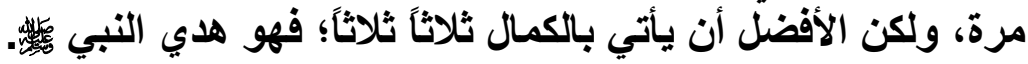
لمسألة لثانية

\section{J صفة aسح}

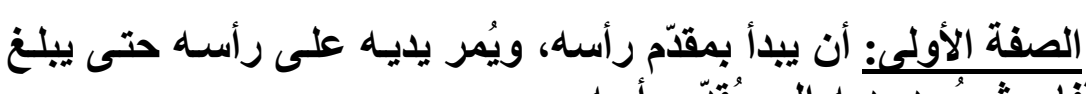

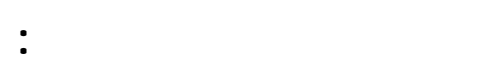

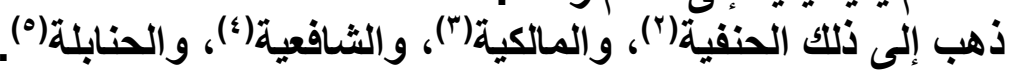

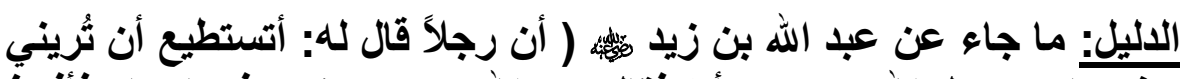

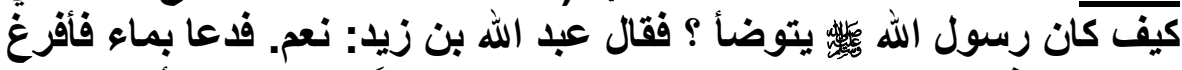

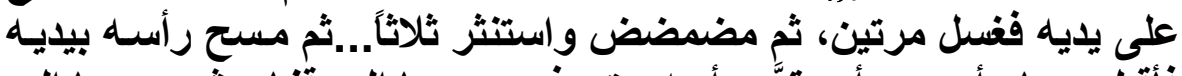

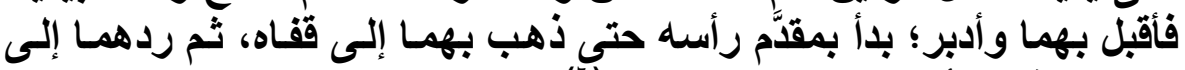

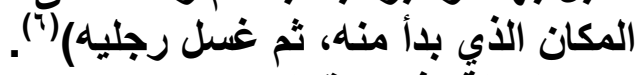

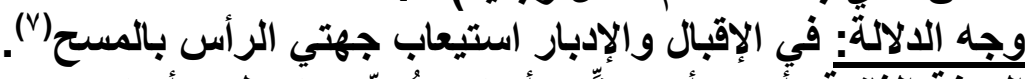

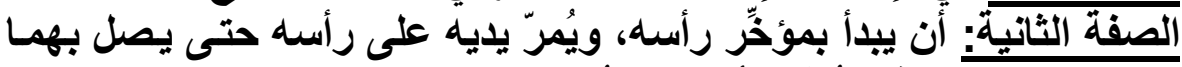

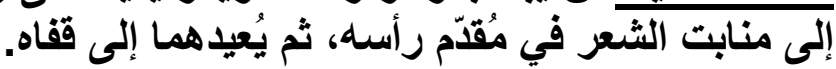

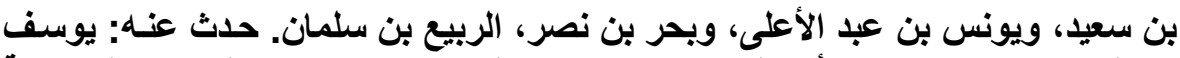

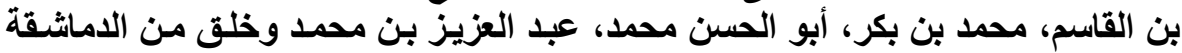

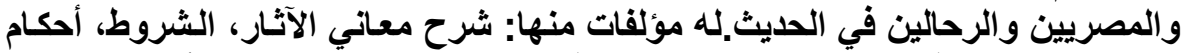

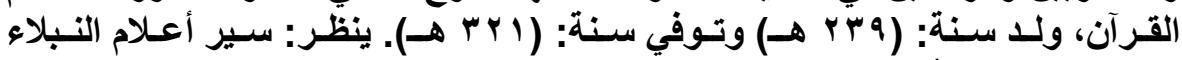

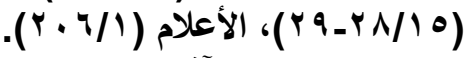

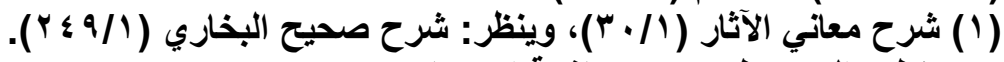

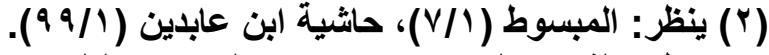

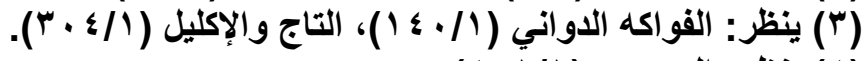

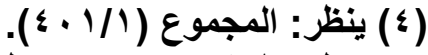

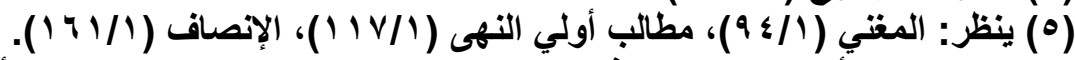

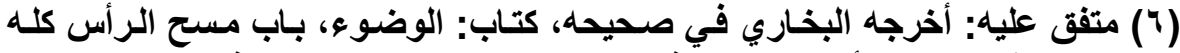

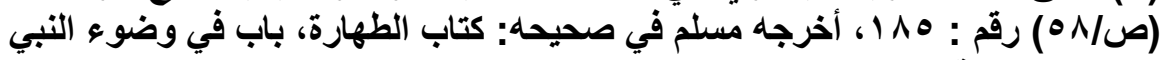

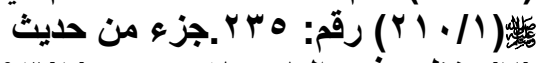

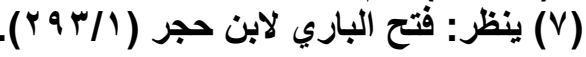




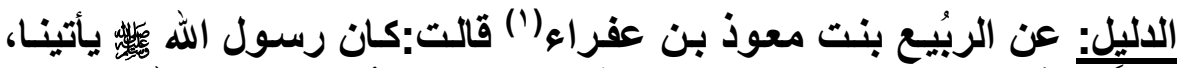

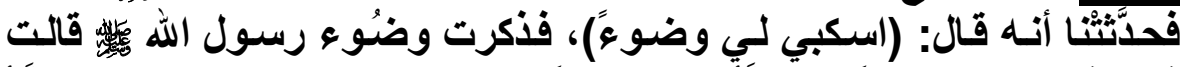

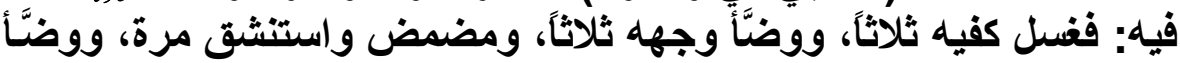

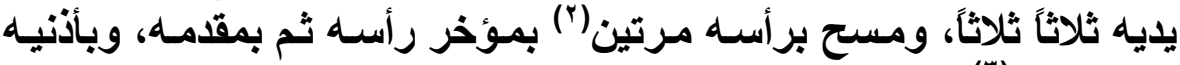

كتيهما... (")

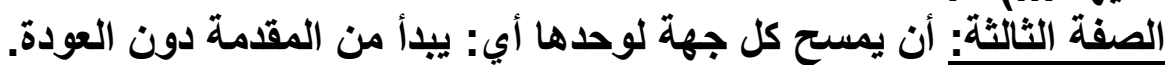

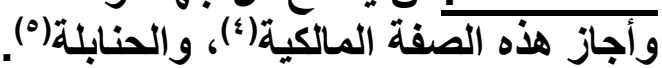

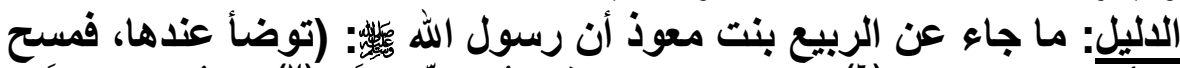

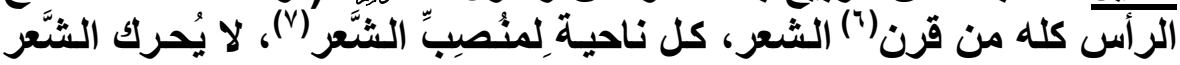

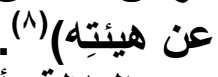

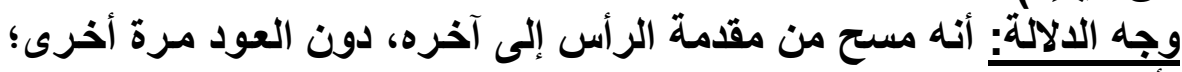

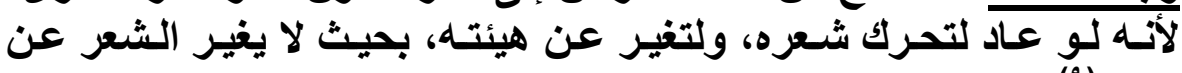
هيiيته (9)

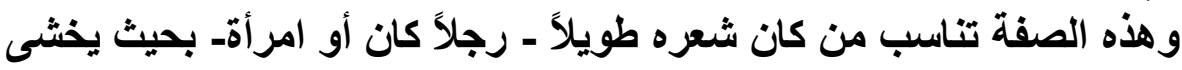

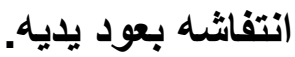

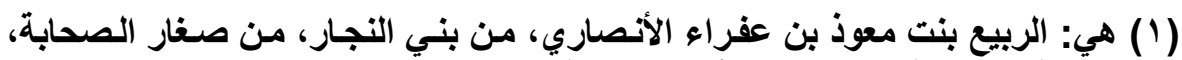

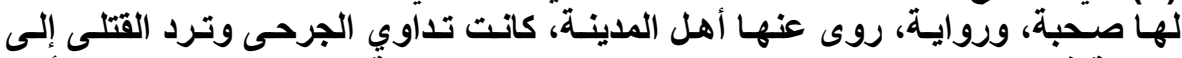

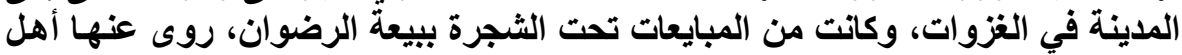

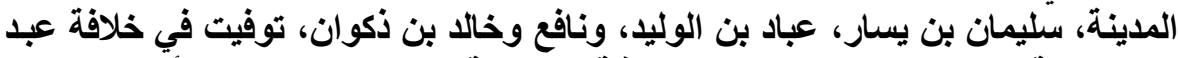

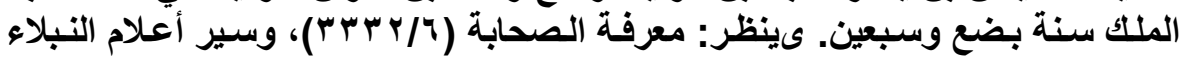
(191/r) (r) أي : محمولة (r) على الإقبال والإدبار، فإنه لما أدبر بيديـه إلى قفـاه هذه مرة، فلمـا عاد

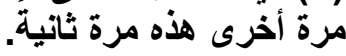

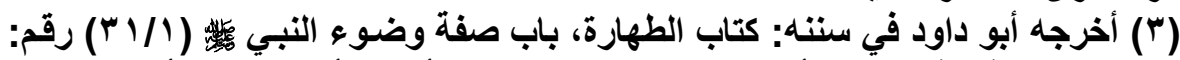

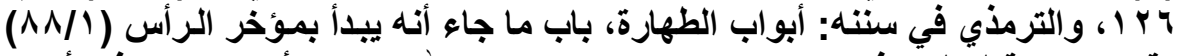

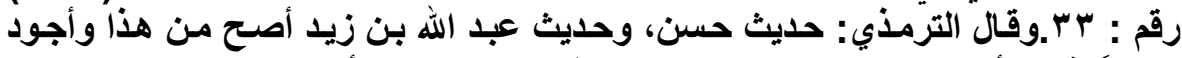

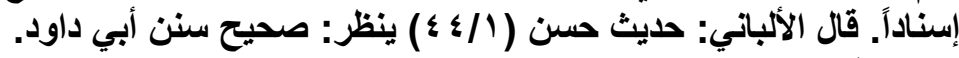

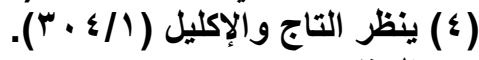

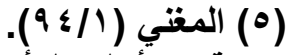
(†) قرن: أُعلى الرأس، أي يبتدئ المسح من الأعلى إلى الأسفل. ينظر: تاج العروس

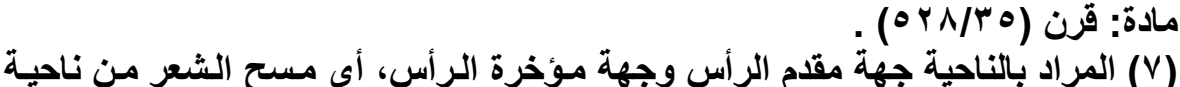

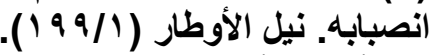

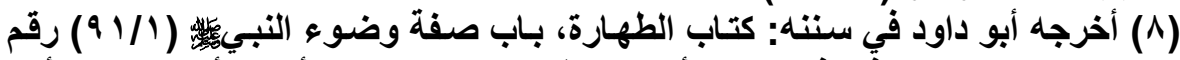

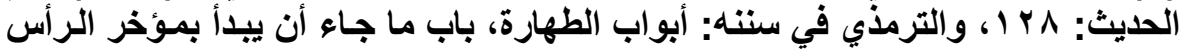

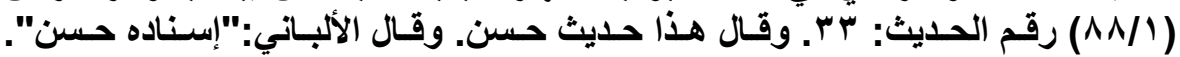

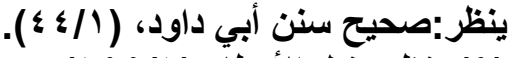
(9) ينظر: نيل الأوطار (199/1) (19). 


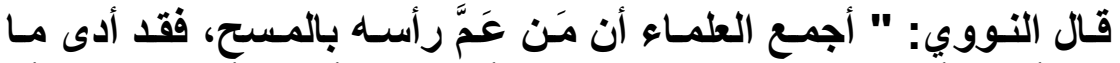

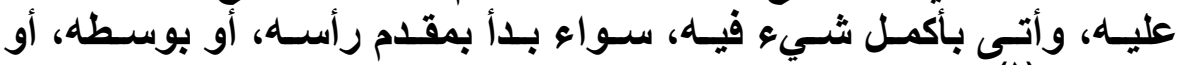

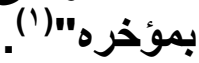

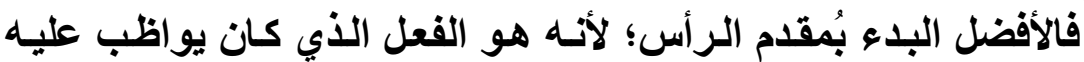

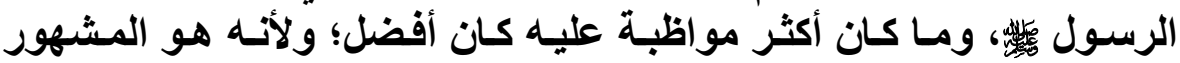

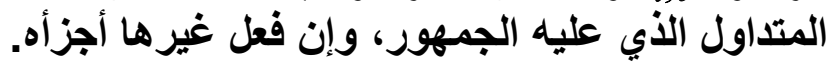
لمسألة لثالثة فئل فئة

صفة غسل ل لجلي في لغسل

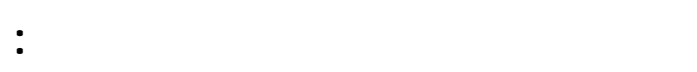

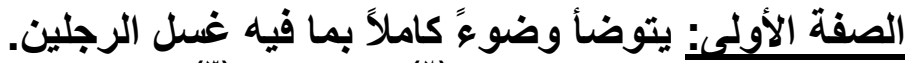

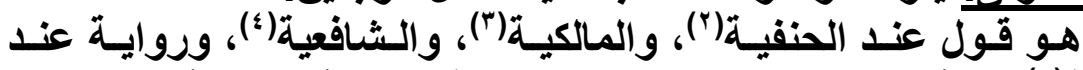

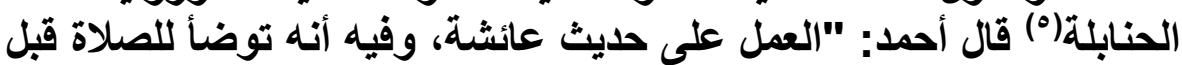

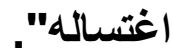

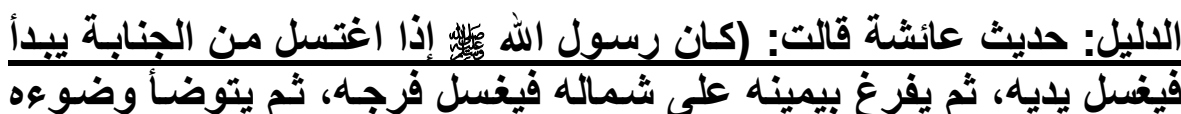

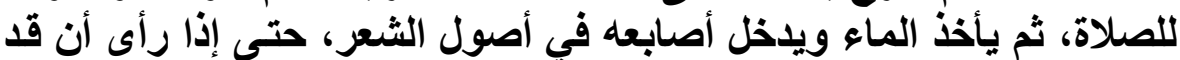

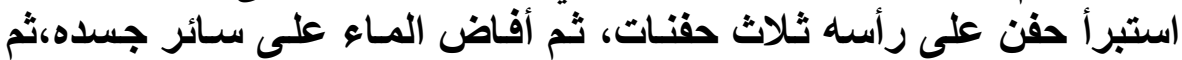

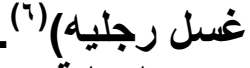
والغسله (الالالـة: إعـادة غسل الـرجلين بعد أن غسلها في الوضـوء لاستيعاب

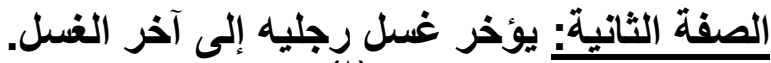

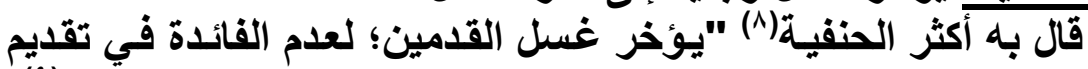

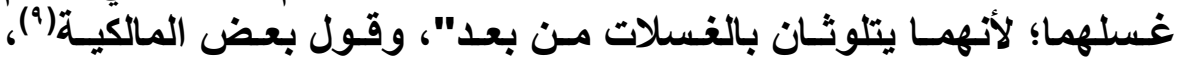

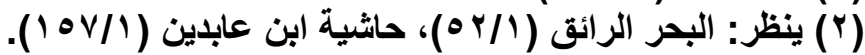

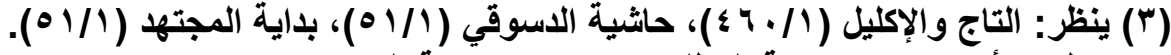

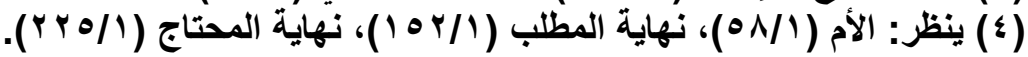

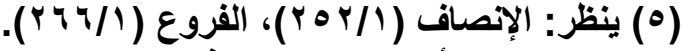

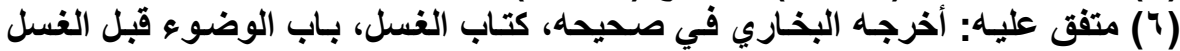

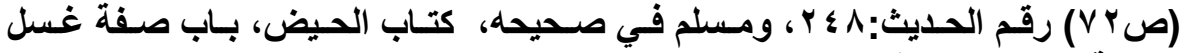

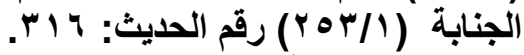

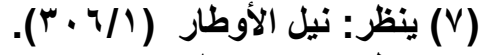

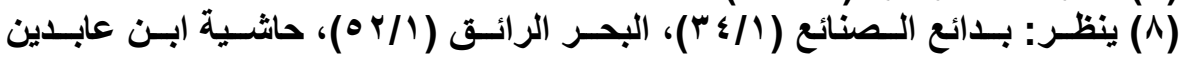
( $(10 \mathrm{~V} / \mathrm{l})$

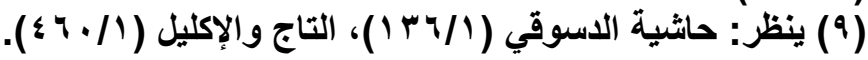




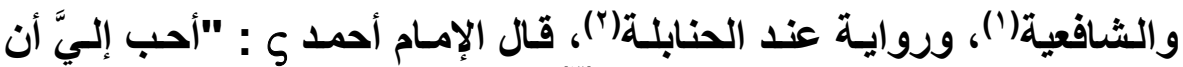

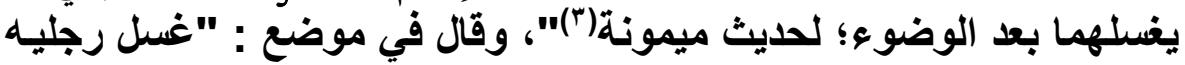

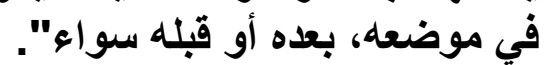

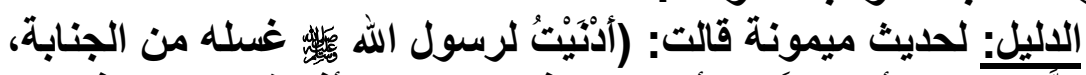

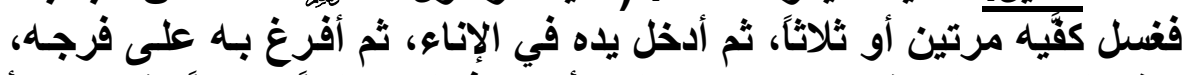

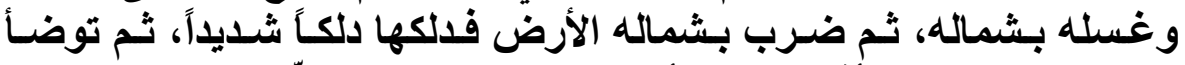

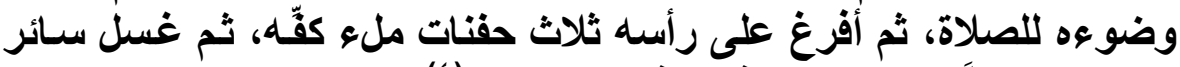

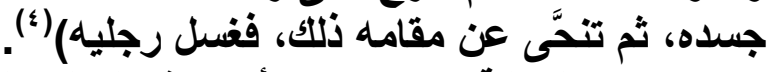

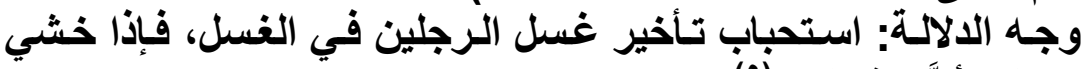

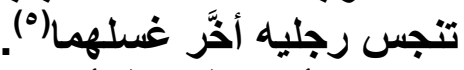
والأقرب في هذا أنه من اختلاف التنوع، ومن العبادات الواردة التي

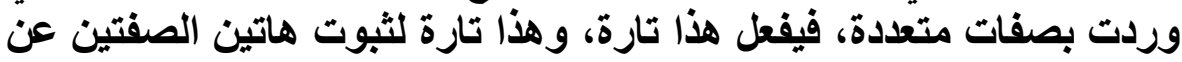
النبي

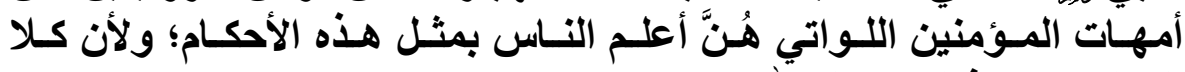

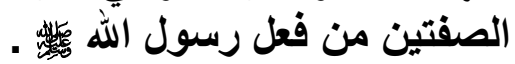
قال الإمام النووي : "وقد ثبت الأمران في الصحيح من فعل رسول الله

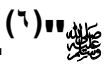

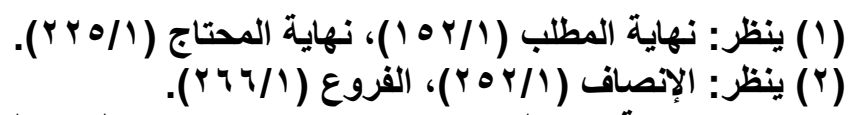

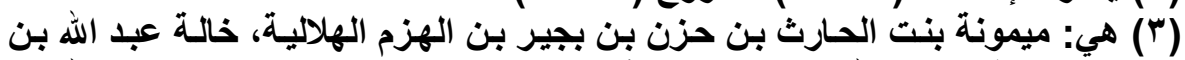

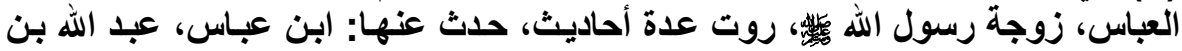

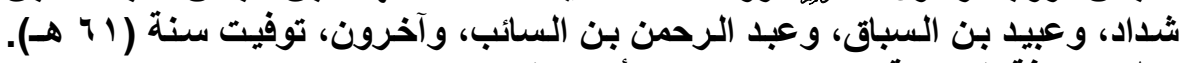

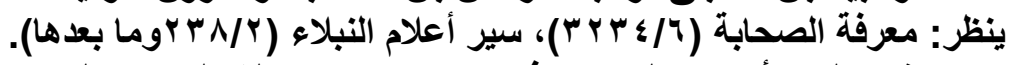

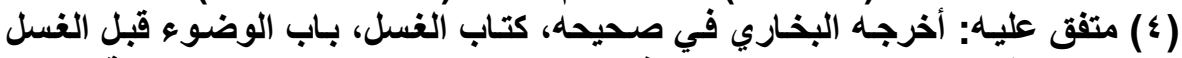

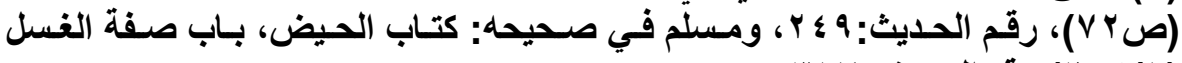

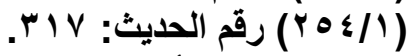

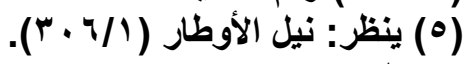




\section{المطلب الثنانبي}

\section{مس1ائل من هيئات الملانة}

لمسألة لأ له

\section{صفة فع لي ي في لتكبي}

لسنة في 共

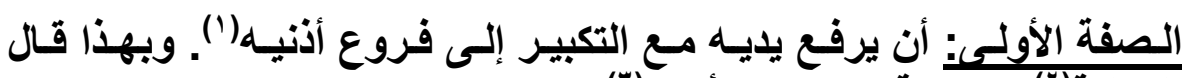

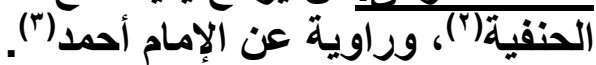

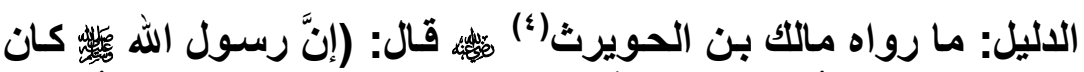

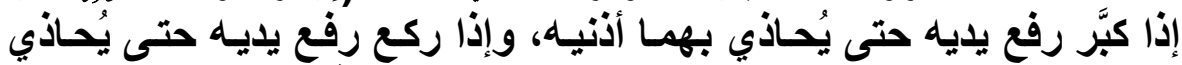

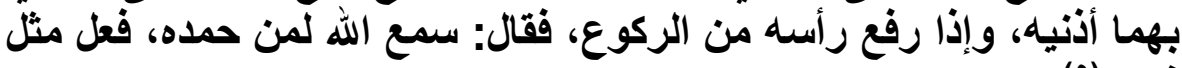

ذلك) (0)

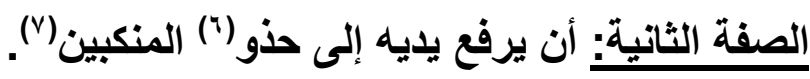

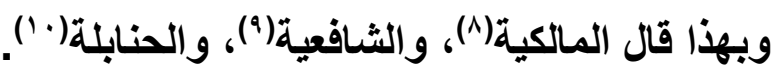

(1) (الفروع: جمع فرع، وهو أعلى الأذن. المطلع على ألفاظ المقنع (ص/9/(1).

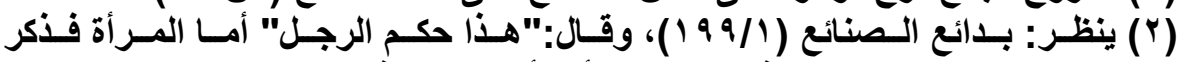

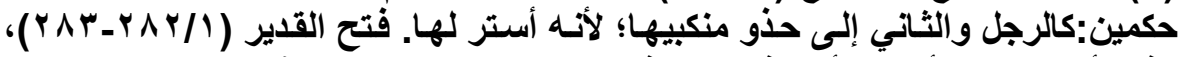

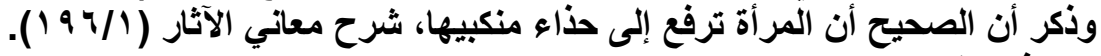

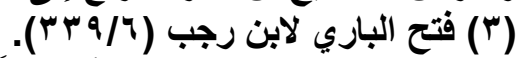

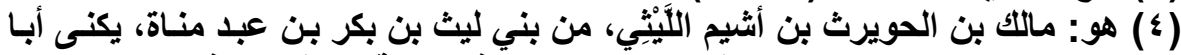

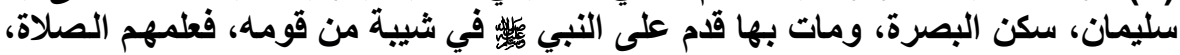

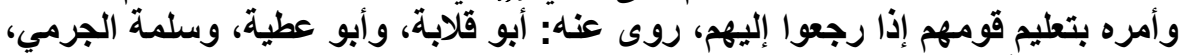

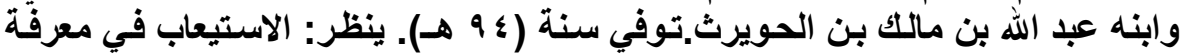

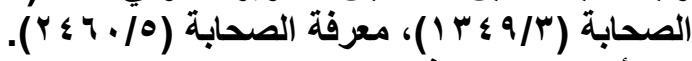

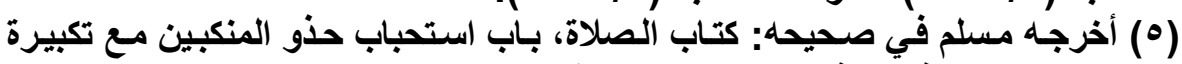

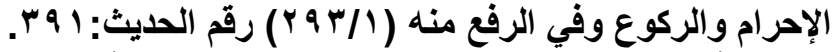

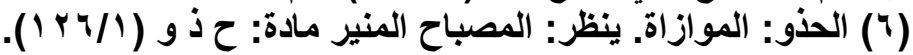

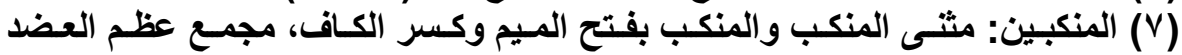

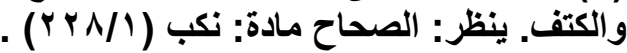

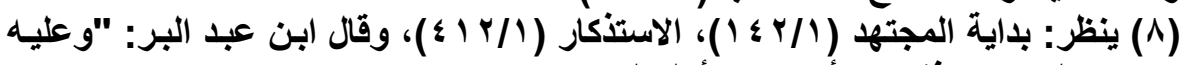

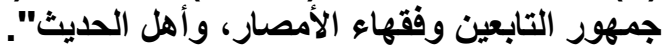

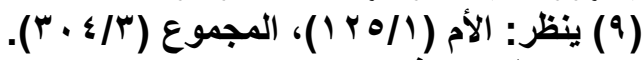

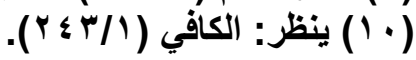




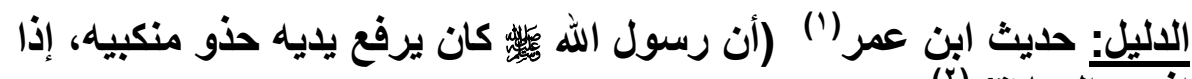

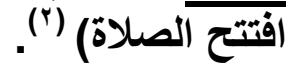

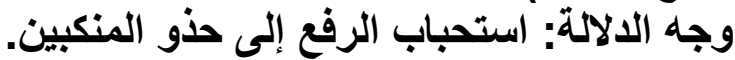

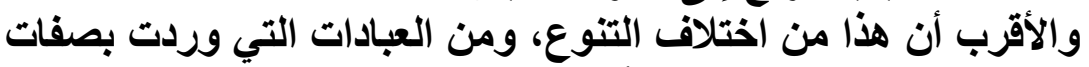

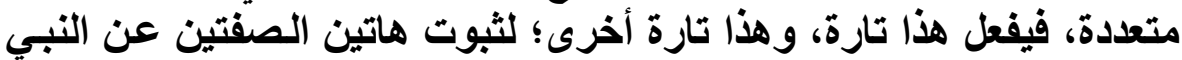
 لمسألة لثانية

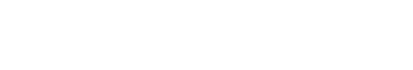

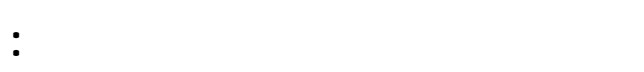

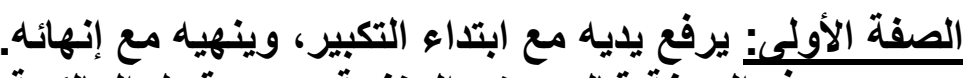

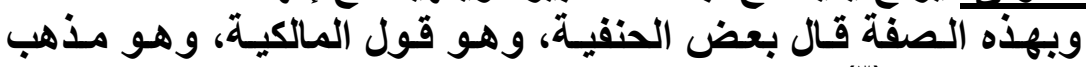

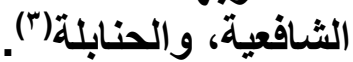

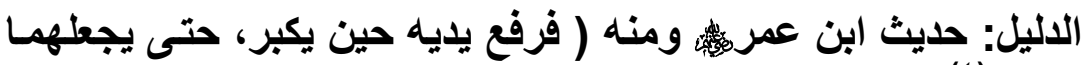

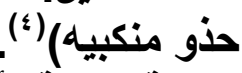
الصفة الثاتية: أن يرفع يديه ثئ يكبر.

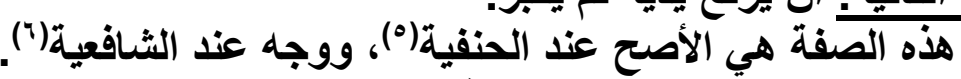

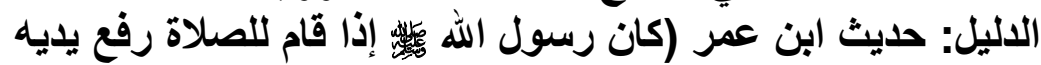

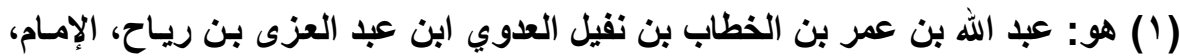

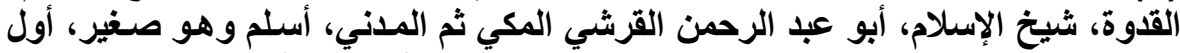

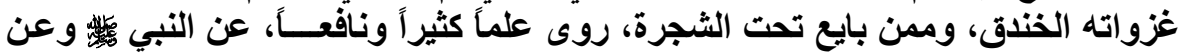

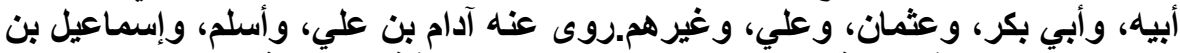

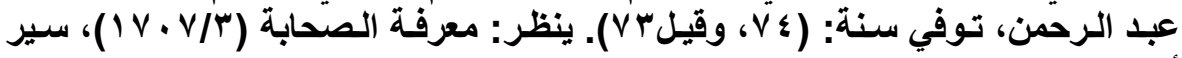

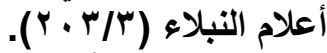

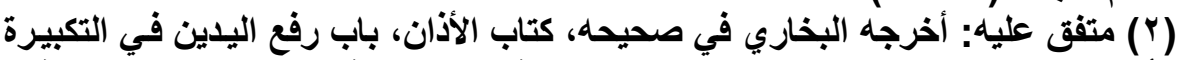

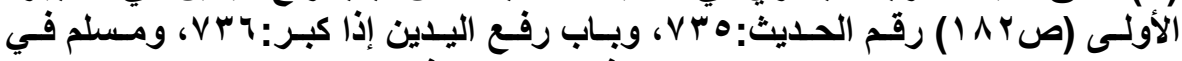

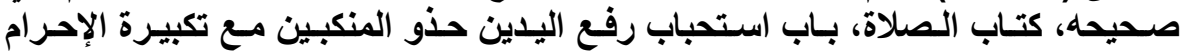

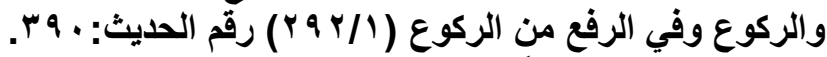

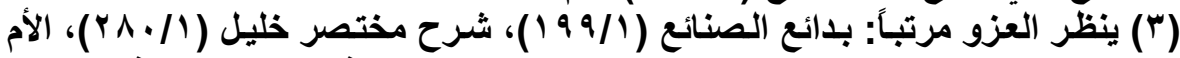

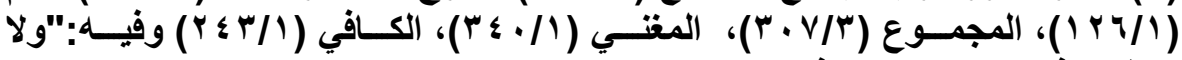

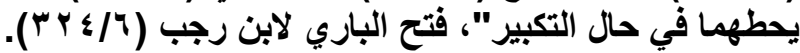

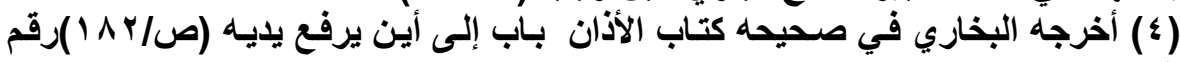

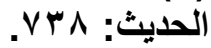

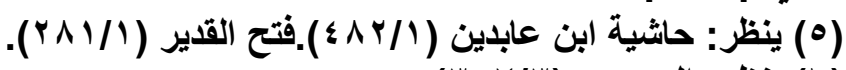

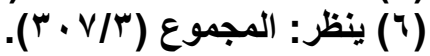




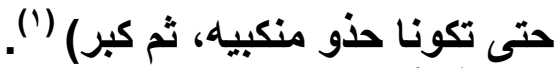

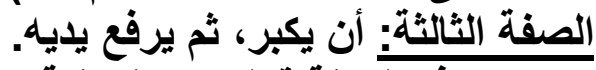

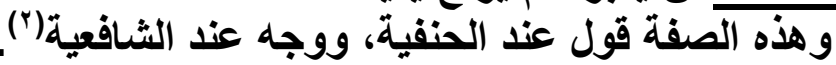

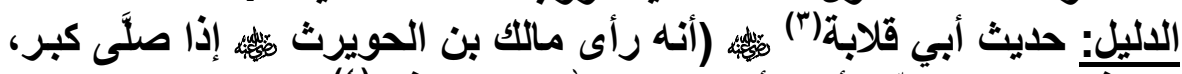

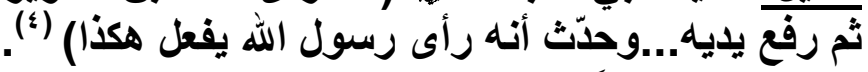

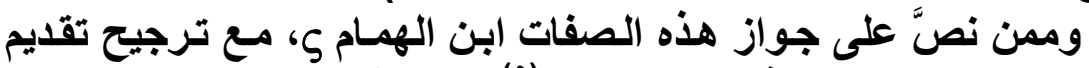

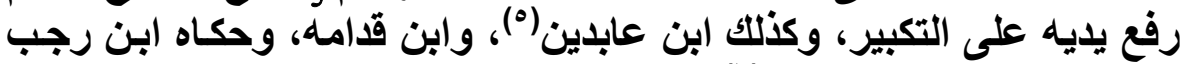
عن جماعة، وكذلاك الألباني (") لمسألة لثالثة

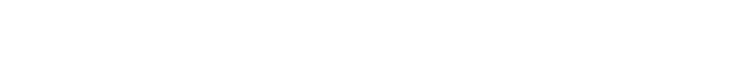

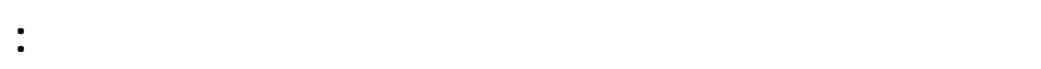

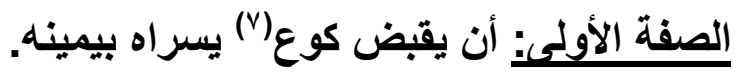

(1) أخرجه مسلم في صحيحه كتاب الصلاة باب استحباب رفع اليدين حذو المنكبين مـع

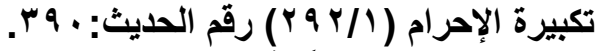

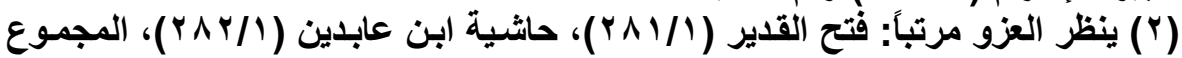
( $1 \cdot(r \cdot r)$

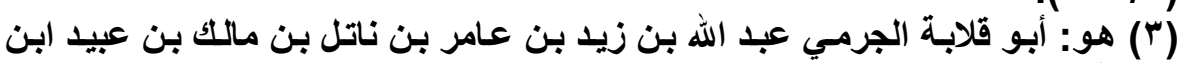

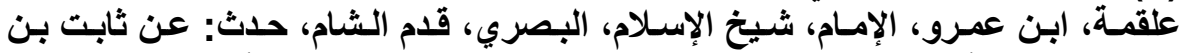

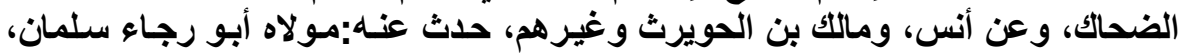

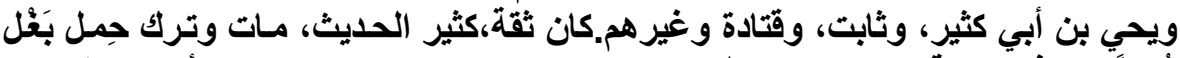

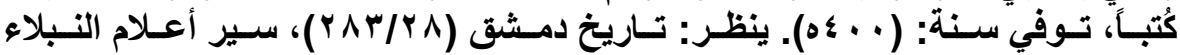

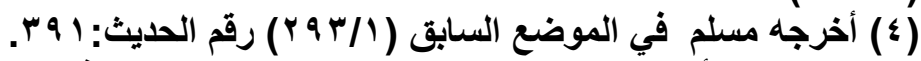
(0) هو: محمد أمين بن عمر بن عبد العزيز عابدين الدمشقي:فقيه الديار الثامية وإمسام

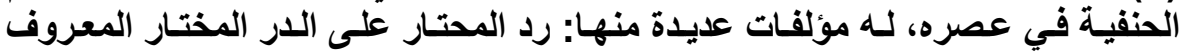

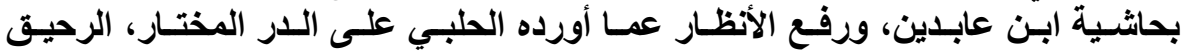

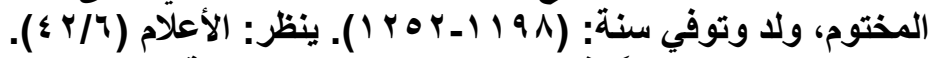

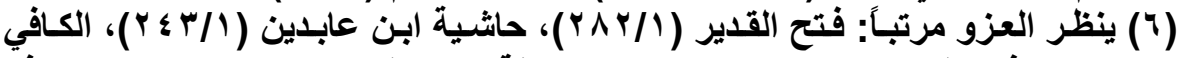

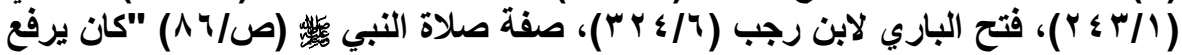

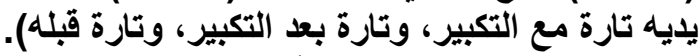

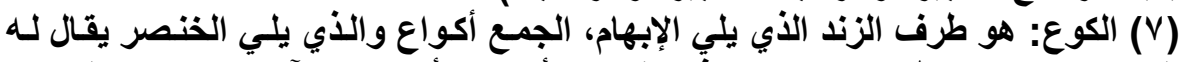

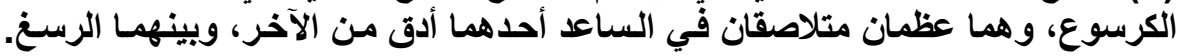

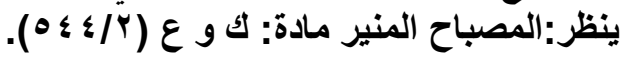




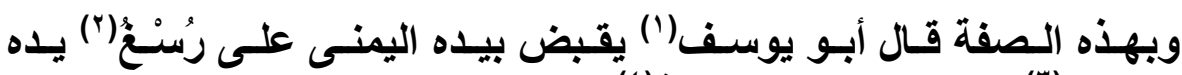

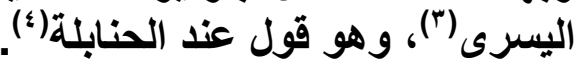

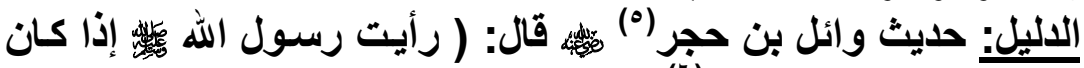

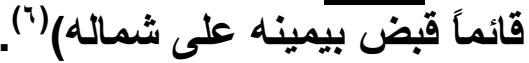

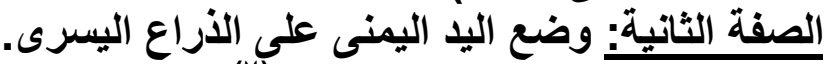

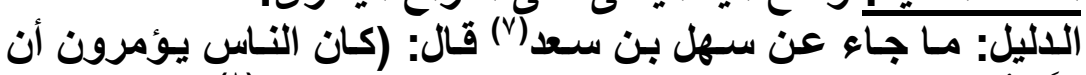

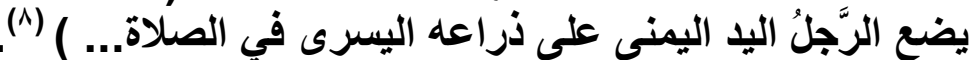

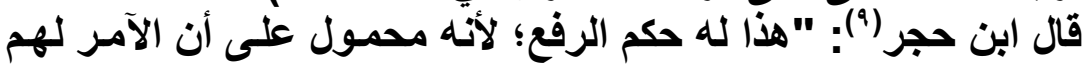

(1) هو: القاضي أبو يوسف يعقوب بن ابراهيم بن حبيب الأنصاري الكوفي، هو الإمـام،

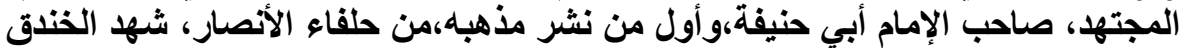

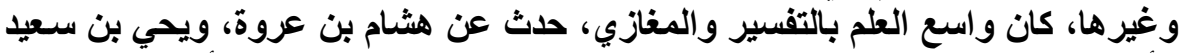

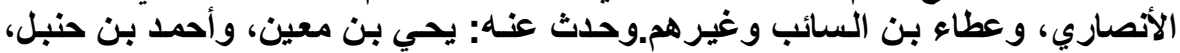

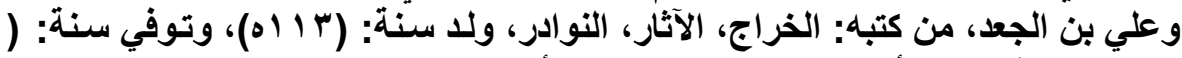

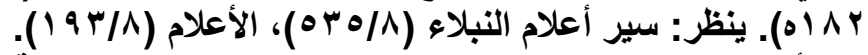

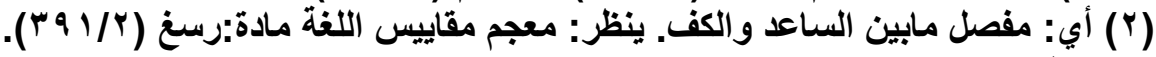

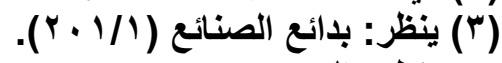

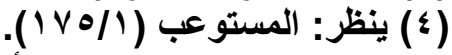

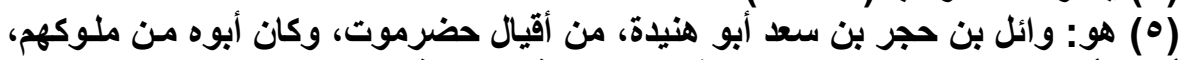

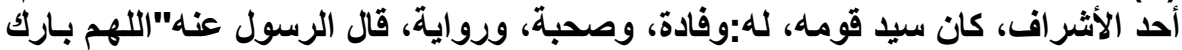

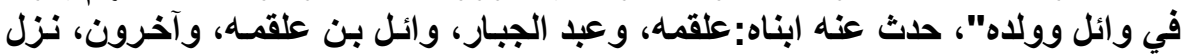

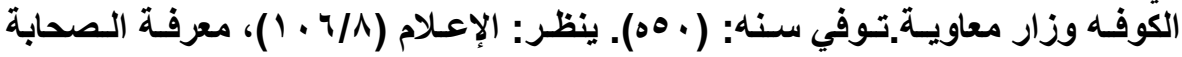

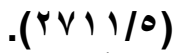

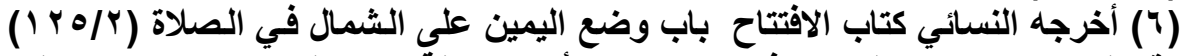

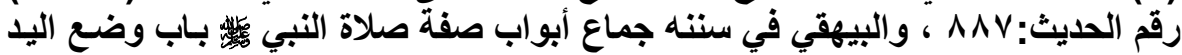

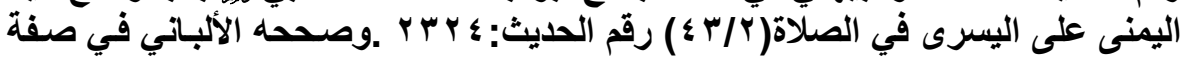

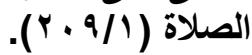

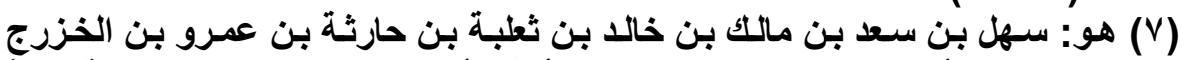

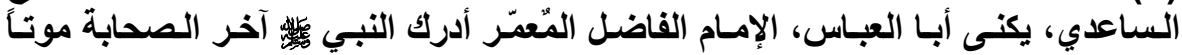

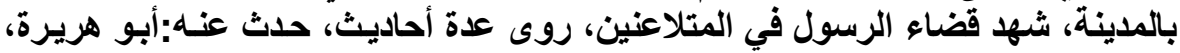

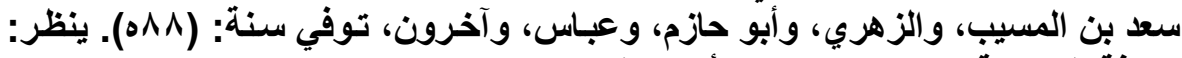

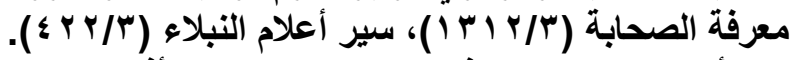

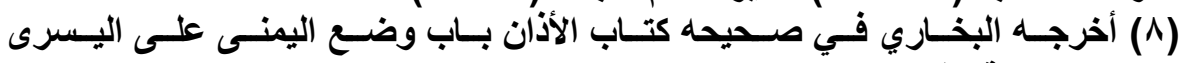

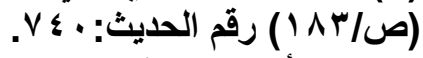

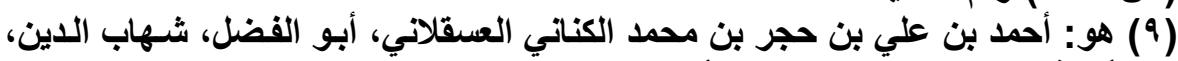

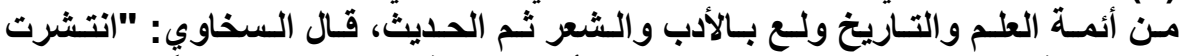

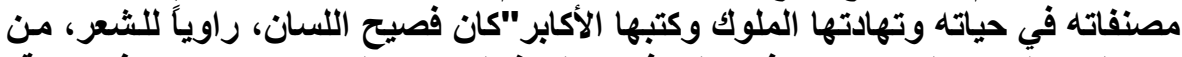

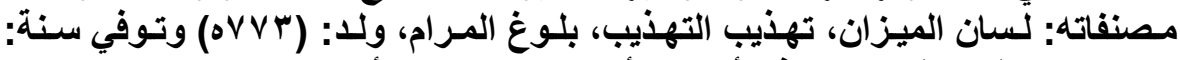

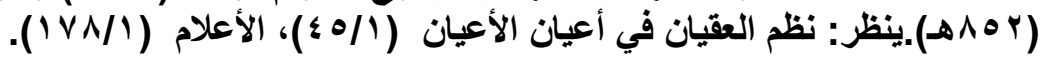




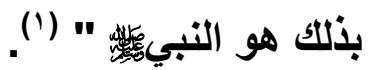

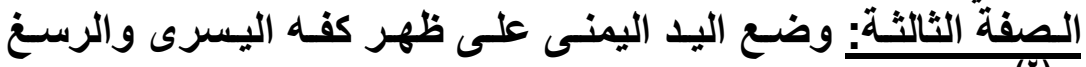
والساعد(r).

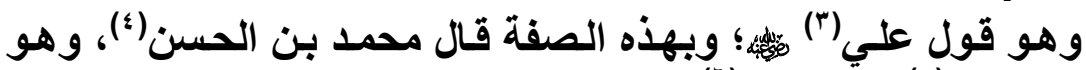

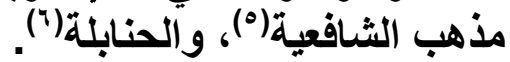

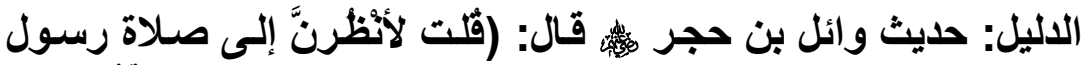

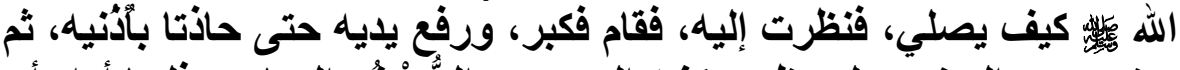

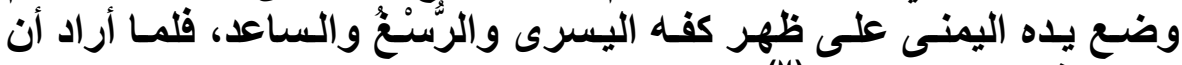

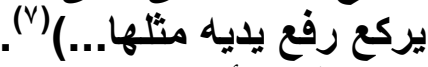
قال الألباني عن الوضع والقبض مناف (الصفة الأولى والثانية): "لفكل سئَّة،

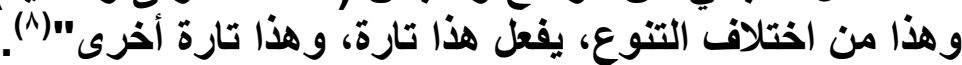

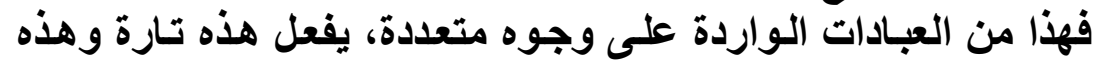

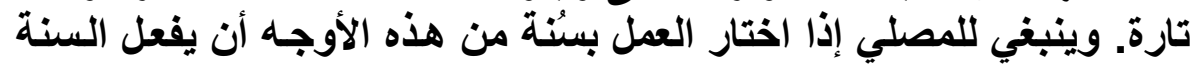

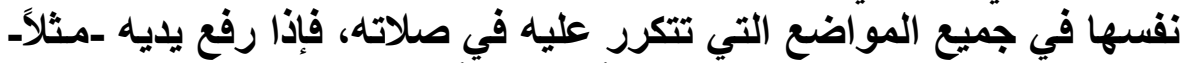

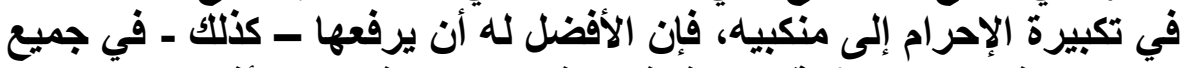
مواضع رفع اليدين الآتية، وهكذا فيما إذا اختار الرفئ الرفع إلى الأنتين.

$$
\text { (1) }
$$

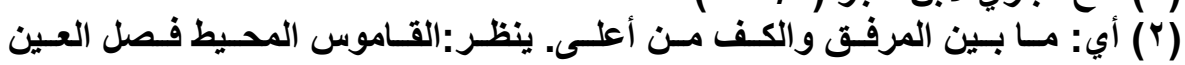

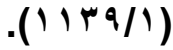

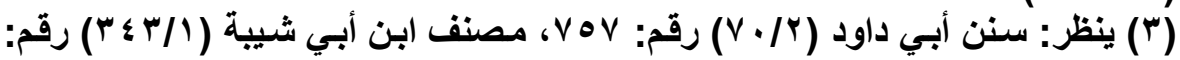
. rq 9 .

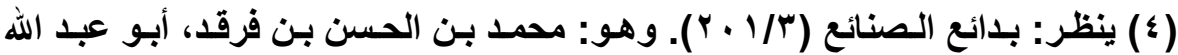

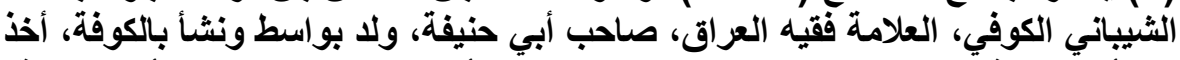

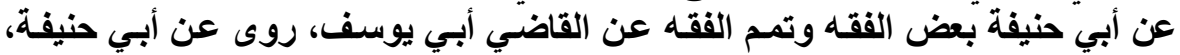

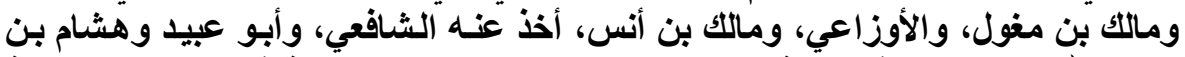

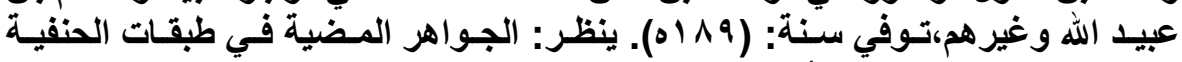

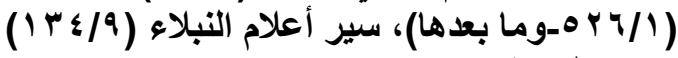

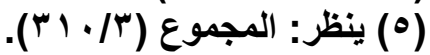

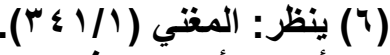

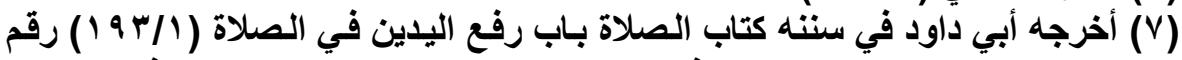

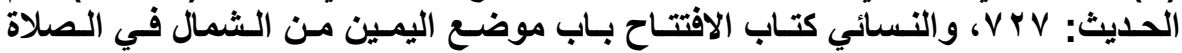

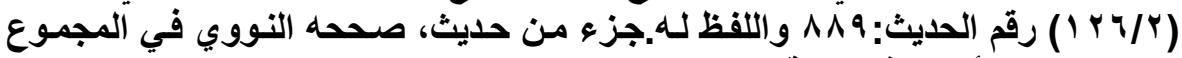

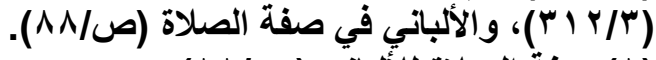

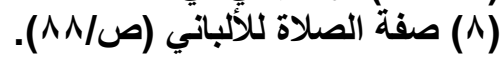




\section{المطلب الثالث}

عبادات واردة على وجوه متعددة في صلاة الجمعة وأحكام الجنائز

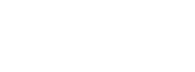

مسائل م صلا لجمعة

فيه مسألتا :

عدد ركعات الراتبة بعد الجمعة

ورد في راتبة صلاة الجمعة عِدَّة صفات، وهي :

الصفة الأولى: ركعتان.

وبه قال الثنافعية وهذا الأقل منها"(')، وكذا عند الحنابلة(")

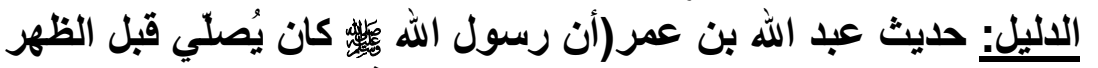

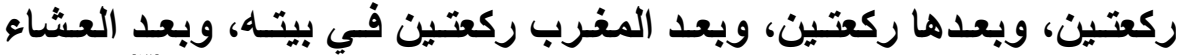

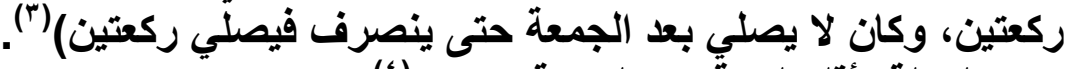

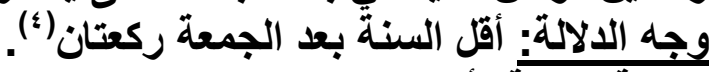

الصففة الثانبة: أربع ركعات.

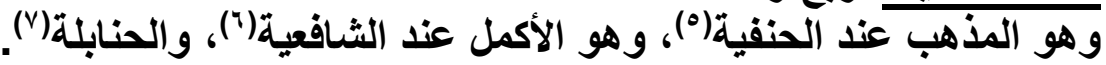

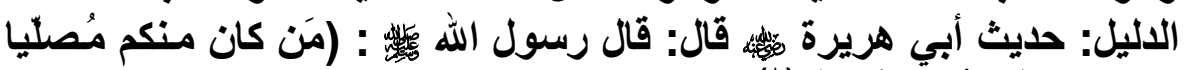

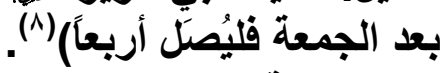

وجه الدلالة: استحباب الصلاة بأريع ركعات(آه".

(1) (1) ينظر: المجموع (9/8). (19)

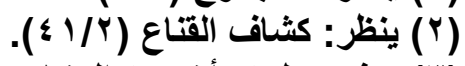

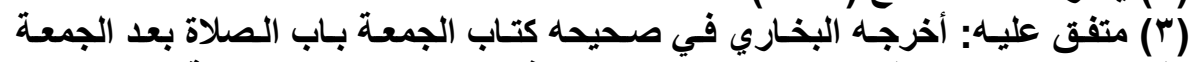

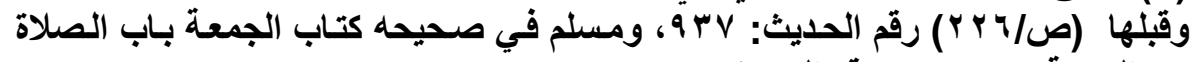

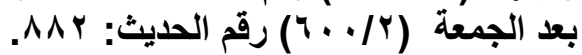

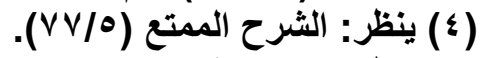

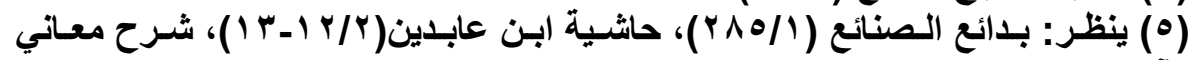

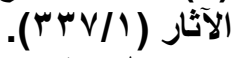

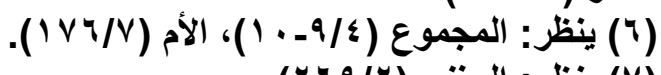

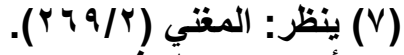

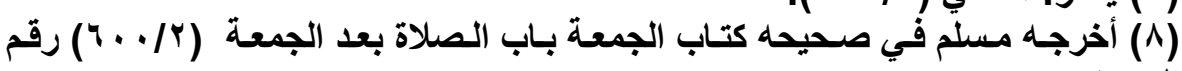
الاحديث: (9) (9نظر: الشرح المتع (VV/0). 
الصفة الثالثة: مت ست ركعات.

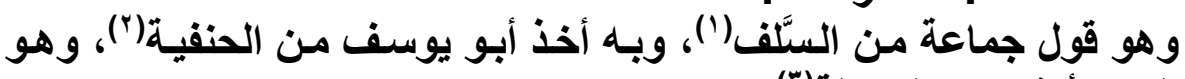

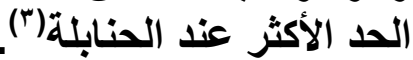

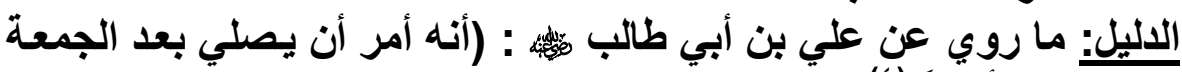
رجاعتين، ثم أربعاً) (4).

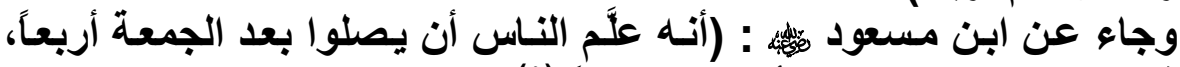

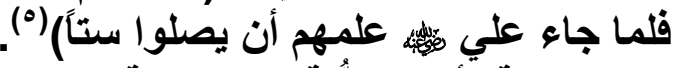

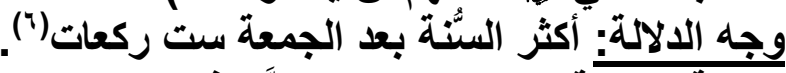

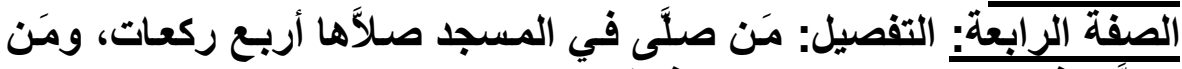

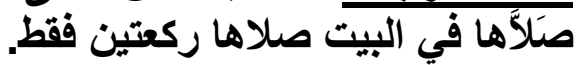

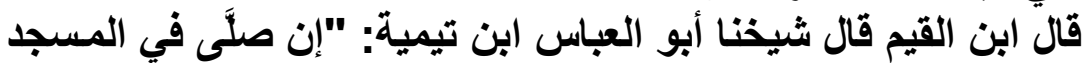

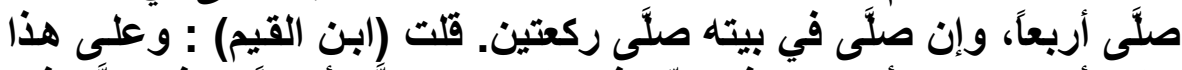

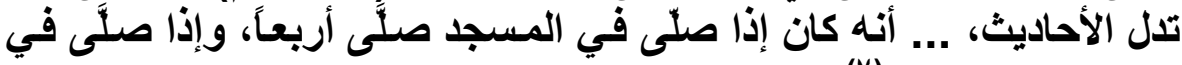

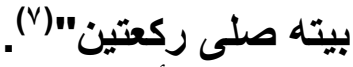

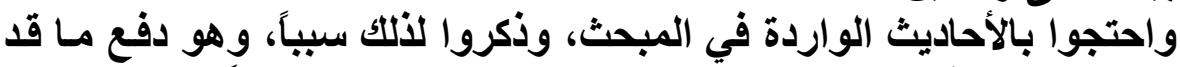

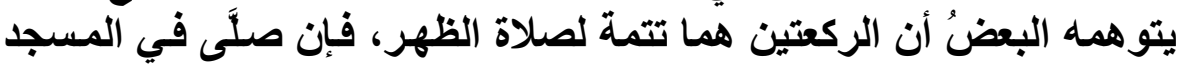

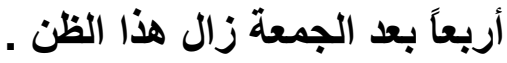

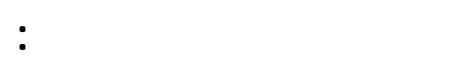

كيف يجمع بين قول النبي ـ عليه الصلاة والسلام -: (إذا صلَّى أحلىكم

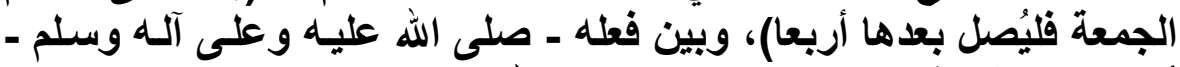

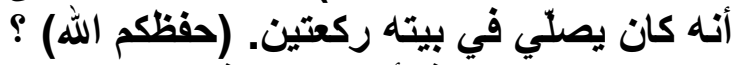

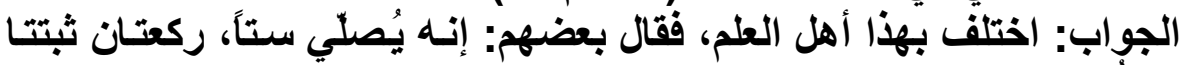
بالسنّة الفعلية، وأربع بالسنة القولية. هذا قول.

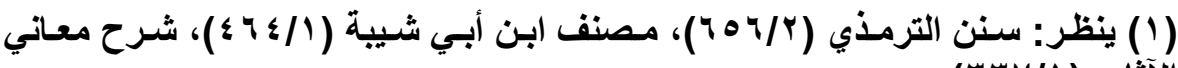

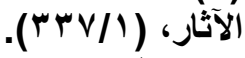

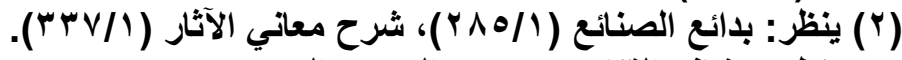

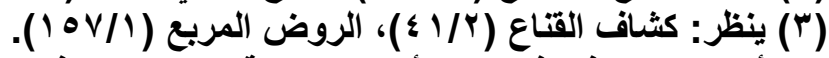

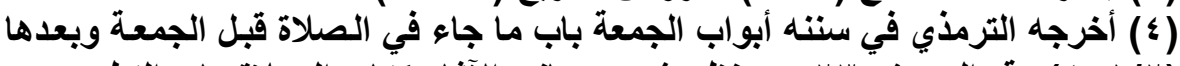

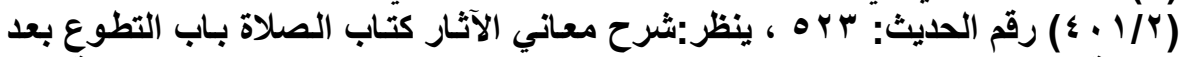

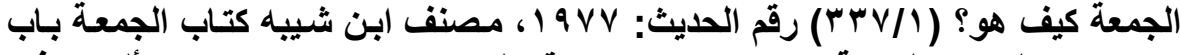

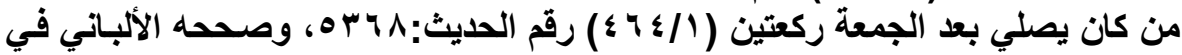

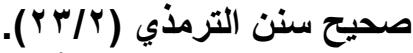

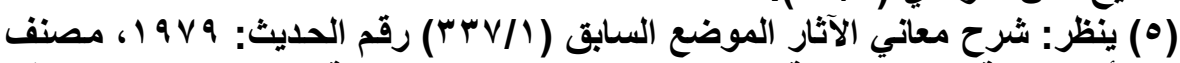

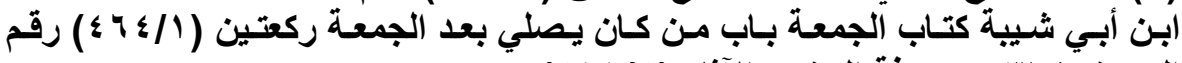

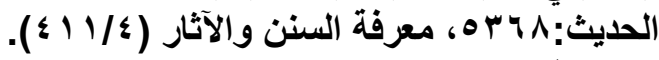

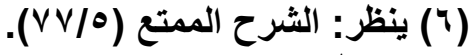

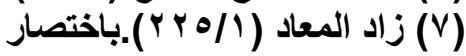




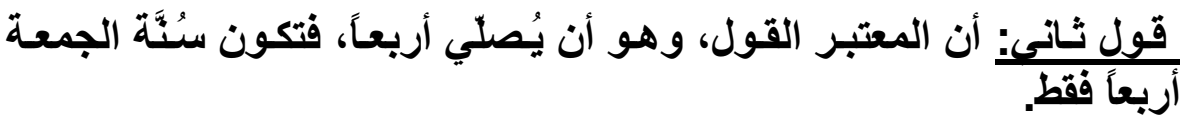

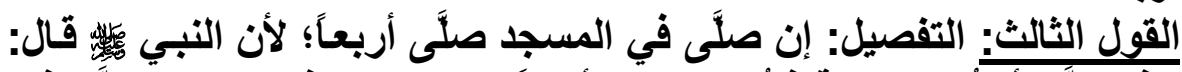

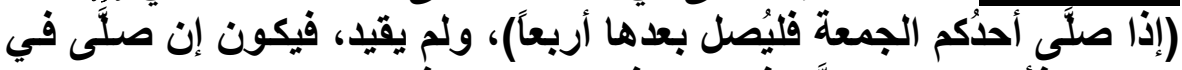

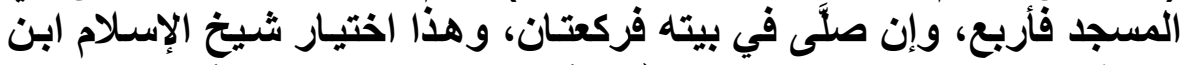

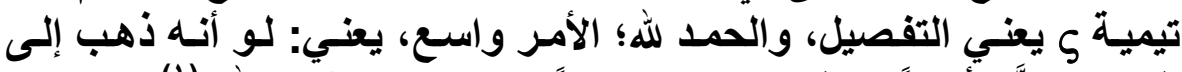

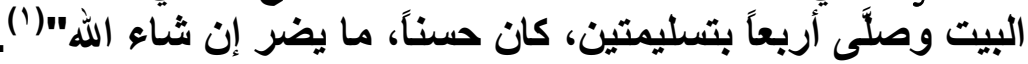

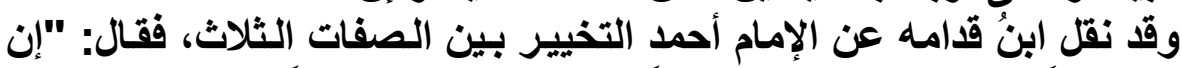

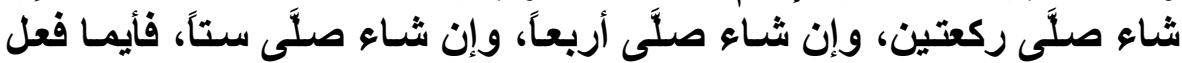

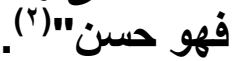
فعدد ركعات الراتبة بعد الجمعة من العبادات الواردة على وجوه متعددة،

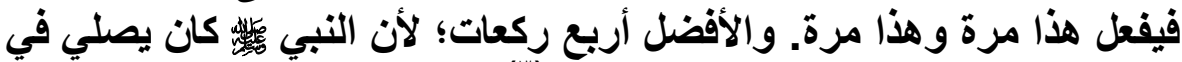

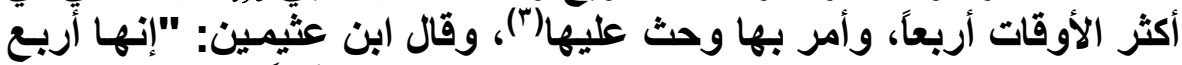

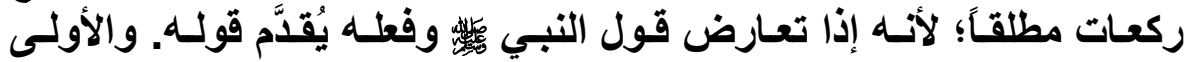
للإنسان - فيما أظنه راجحاً. أن يصلّي أحياتًا أربعاً، وأحياناً ركتين.

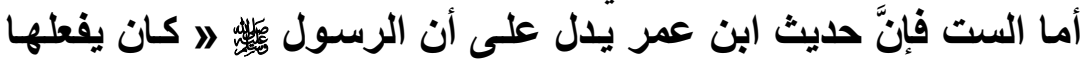

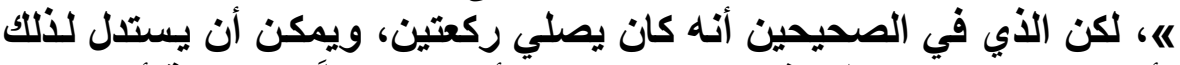

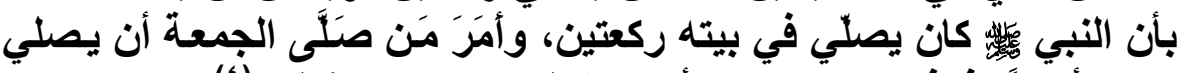

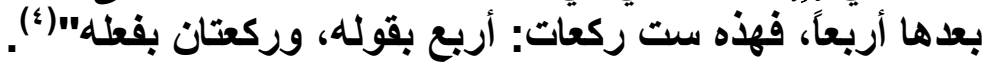

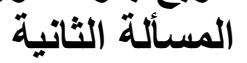

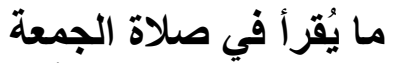

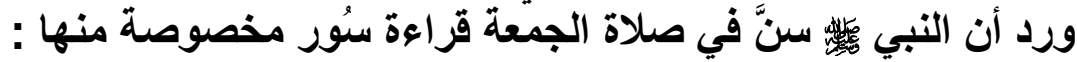
الصفة الأولى: أن يقرأ في الركعة الأولى بسورة الأعلى، وفي الثانية بسورة

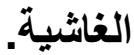

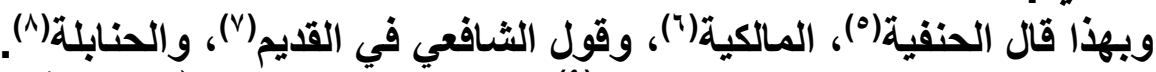

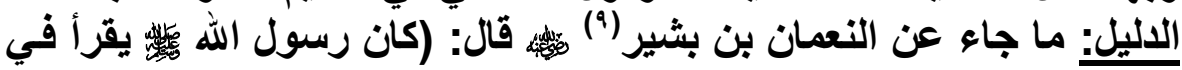

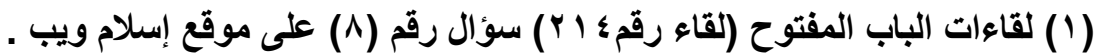

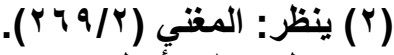

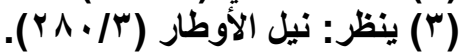

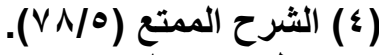

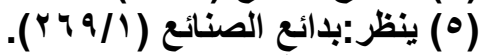

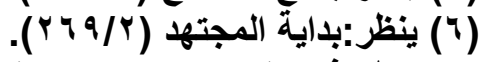

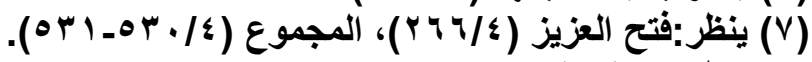

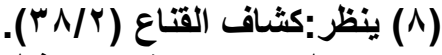

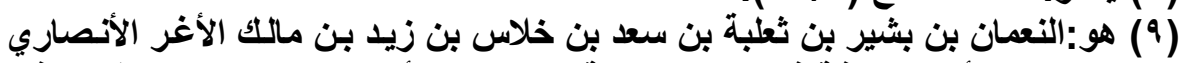

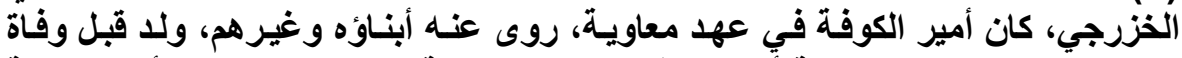

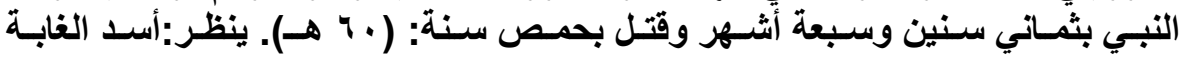


العيدين وفـي الجمعـة بـ "سـبح اسـم ربــك الأعلىل، و"هـل أنـاك حـيث

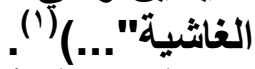
الصفةً الثانية: أن يقرأ في الركعة الأولى بسورة الجمعة، وفي الثانية بسورة المنافقون. وهذا وجه عند الحنفية(")، وقول عند الثنافعية(")، والحنابلة) (4).

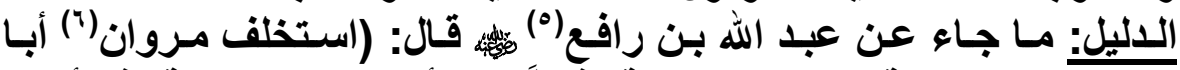

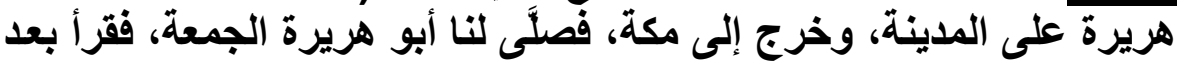

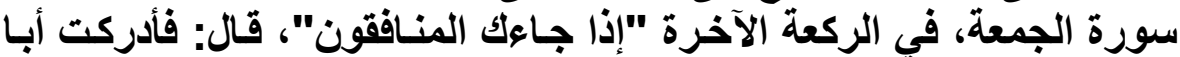

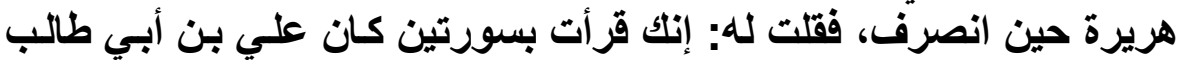

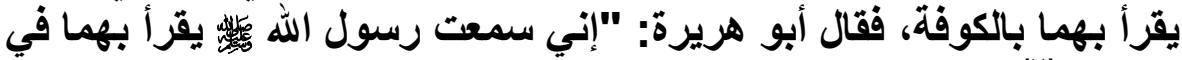

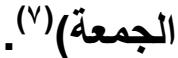
الغاثيةة. الثالثة: أن يقرأ في الركعة الأولى بسورة الجمعة، وفي الثانية بسورة وبهذا قال المالكية(م). اللدليل: لما ثبت أن الضحاك بن قيس(9) كتب إلى النعمـان بن بشير، يسأله:

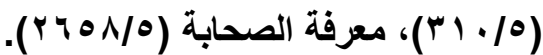
(1) أخرجه مسلم في صحيحه كتاب الجمعة باب ما يقرأ في صلاة الجمعة (r/109/ه) رقم

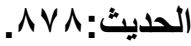
(r)

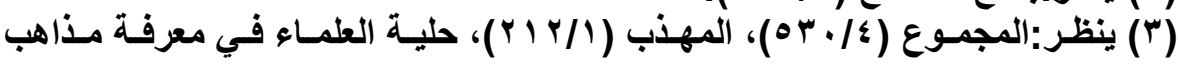

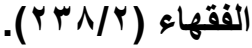

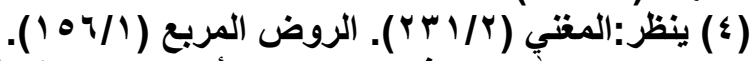

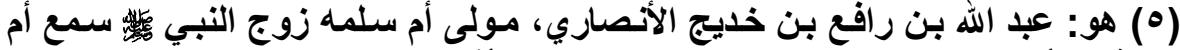

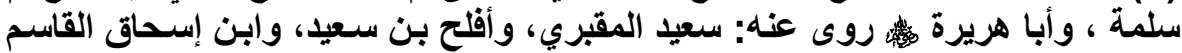

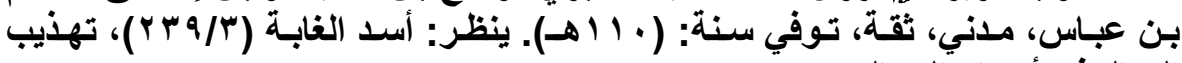

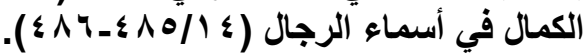

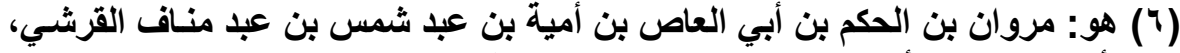

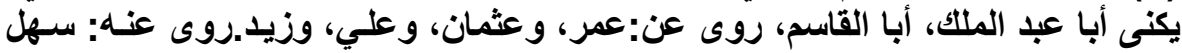

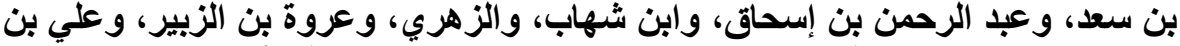

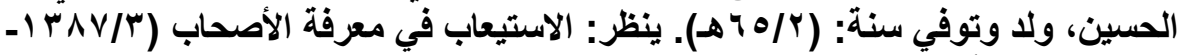

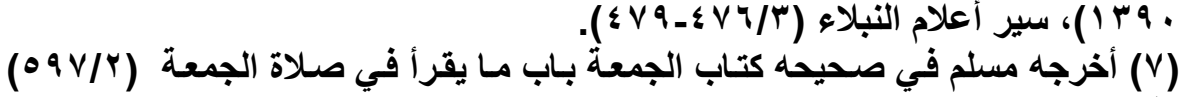

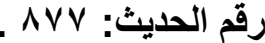

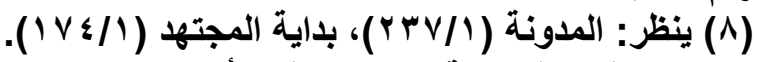

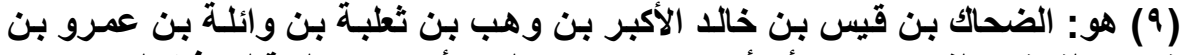

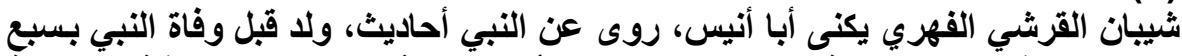

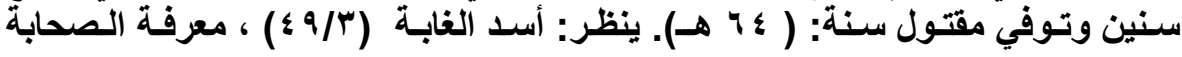


(أي شيء قرأ رسول الله بـ يوم الجمعة، سوى سورة الجمعة؟ فقال: "كان

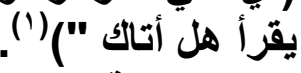
وجـه الدلالـة من الأحاديث: تعدد كيفيـات قراعة الجمعة، فلا وجـه لتفضيل

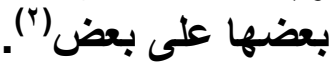

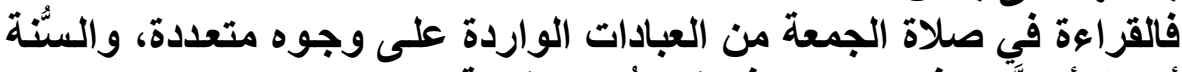

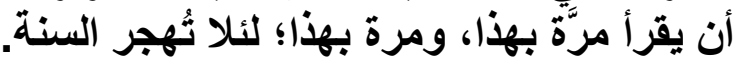

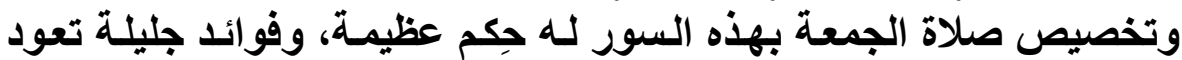
على المصلي بالنفع عاجلاً وآجلاً.

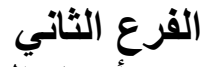

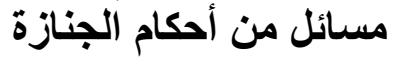
فيه مسألتا :

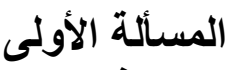

عدد التكبيرات في صلاة الجنازة

ورد التكبير على الجنازة بصفات متعددة منها:

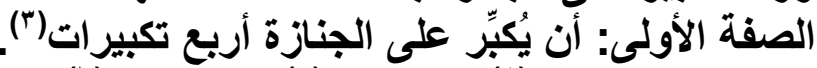

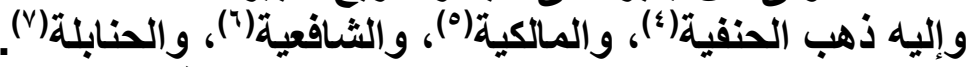

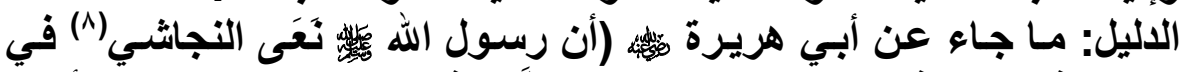

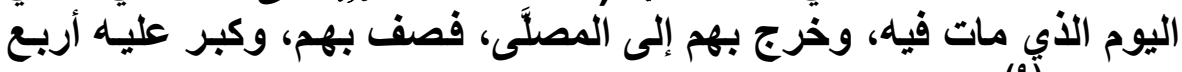

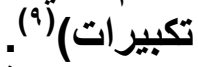
وجـه الدلانة: التكبير على الجنـازة يكون بـأربع تكبيرات، ولا ينفص عن

(1) أخرجه مسلم في صحيحه كتاب الجمعة باب ما يقرأ في صلاة الجمعة (Y/N9 ه) رقم

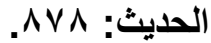

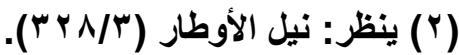

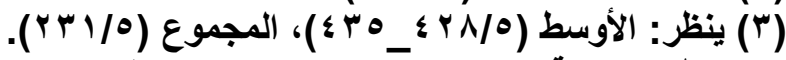

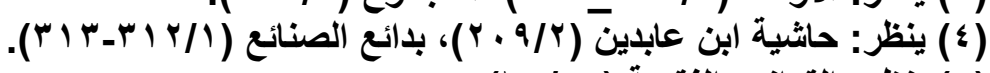

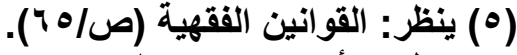

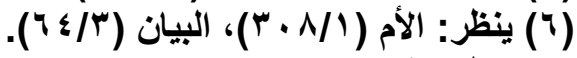

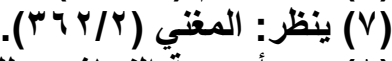

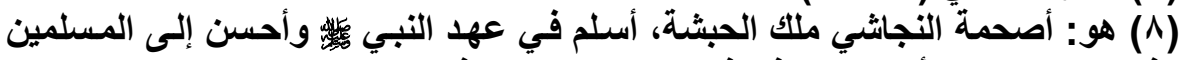

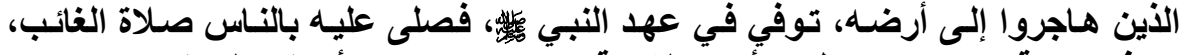

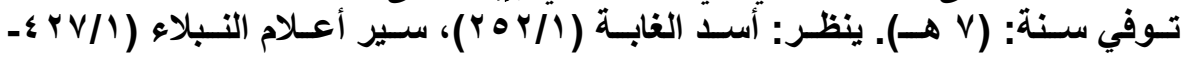

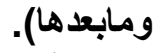
(9) متفق عليه: أخرجه البخاري في صحيحه كتاب الجنائز باب التكبير على الجنازة

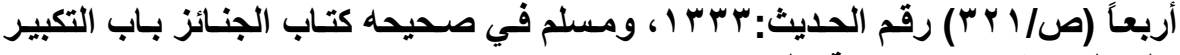

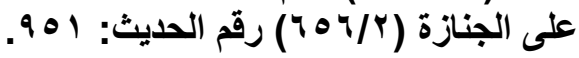


ذلك (')

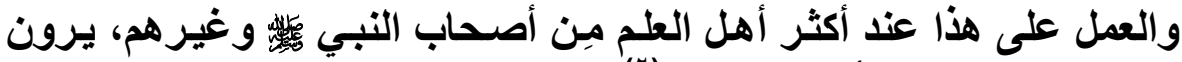

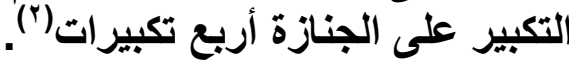

قال ابن حجرى : "وهو الذي جمع أنع عمر بن الخطاب الصحابة على العمل

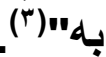

الصفة الثانية: أن يُكبّر على الجنازة خمسا.

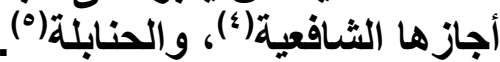

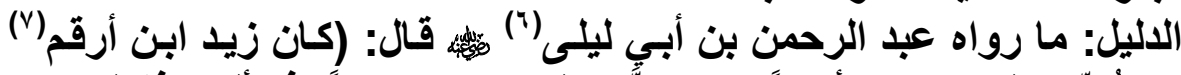

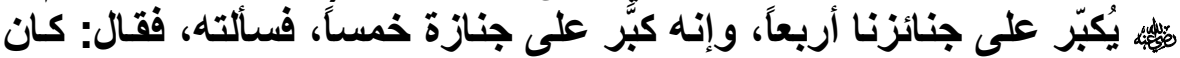

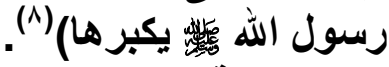

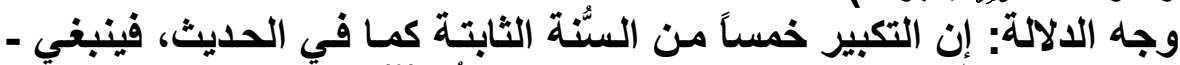

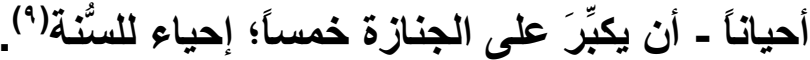

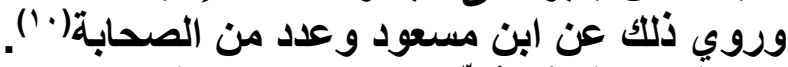

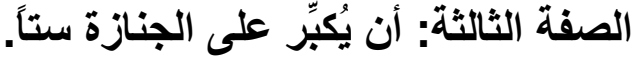

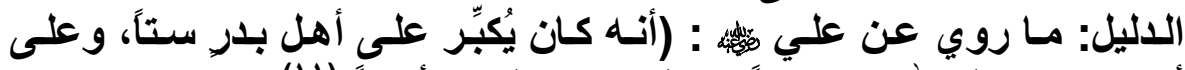

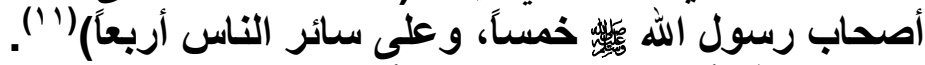

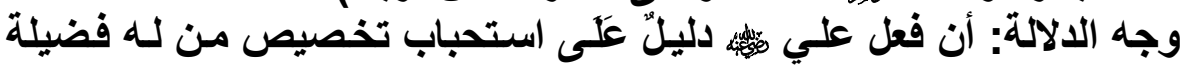

$$
\begin{aligned}
& \text { (Y) ينظر: فتح الباري لابن حجر (r/r/r (Y). }
\end{aligned}
$$

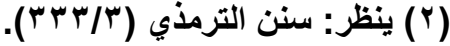

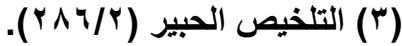

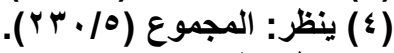

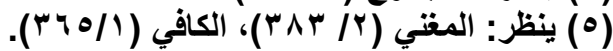

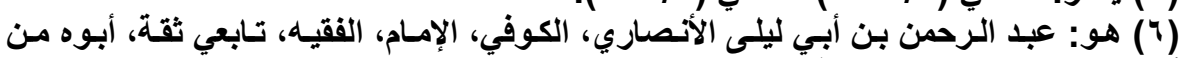

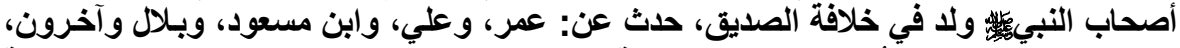

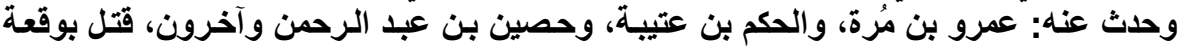

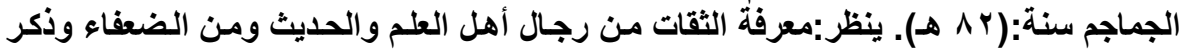

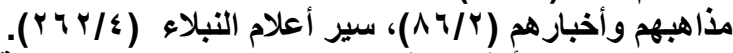

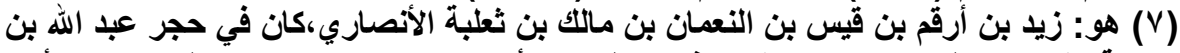

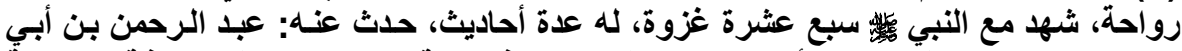

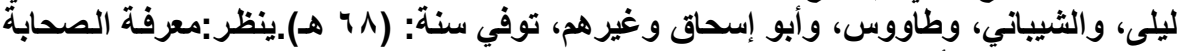

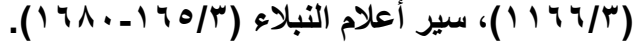

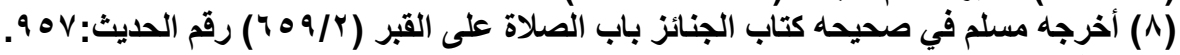

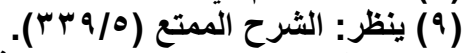
( • (1) ينظر: روايات عدد من الصحابة في التكبير خمس تكبيرات في المصنف لابن أبي شيبة . ( $(\leqslant 97 / r)$ (11) أخرجه الدارقطني في سنته كتاب الجنائز باب التسليم في الجنائز واحد والتكبير أربعاً

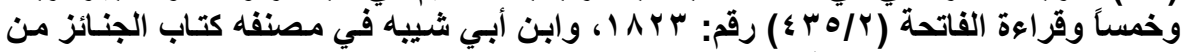

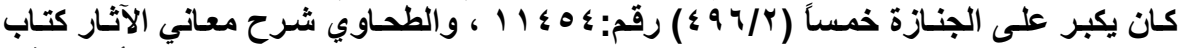

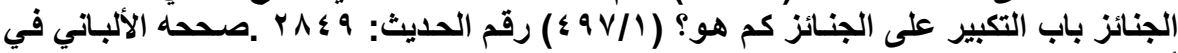

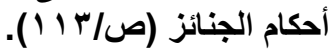




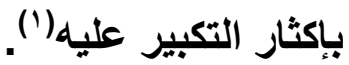

الصفة الرابعة: أن يكبر على الجيز الجنازة سبعاً.

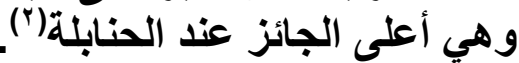

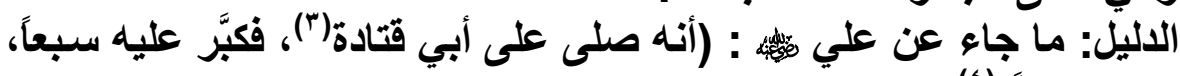

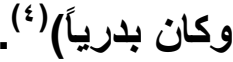

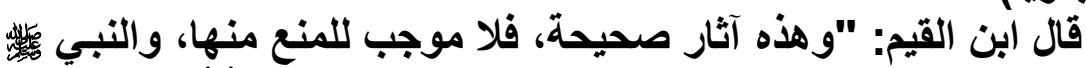

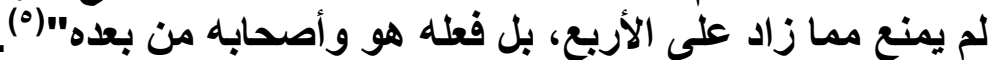

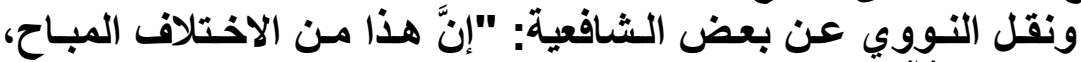

والجميع جائز""(").

وقال ابن تيمية: "التكبيز على الجنائز يجوز على المشهور: التربيع،

والتخميس، والتسبيع" (v) وليمية:

والقول بأن جميع الوارد جائز هو اختيـار شيخ الإسـلام ابن تيميـة(^)،

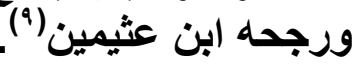

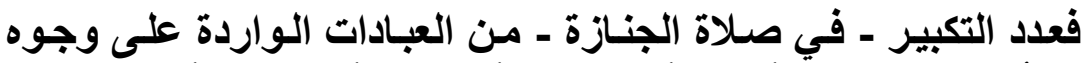

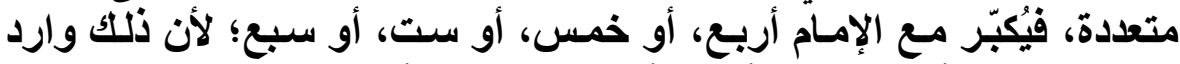

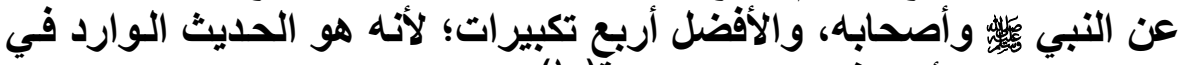

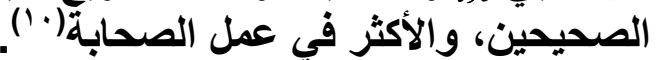

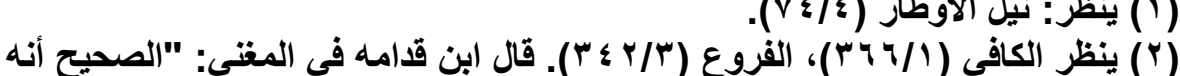

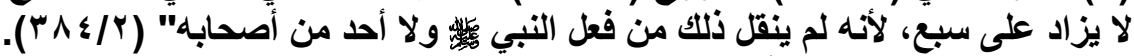

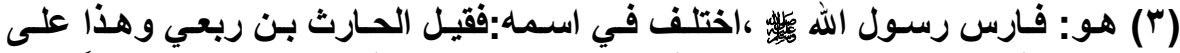

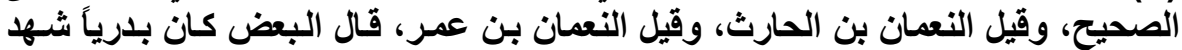

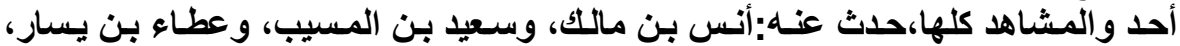

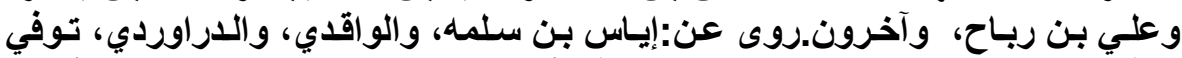

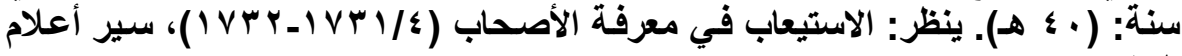

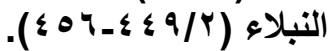

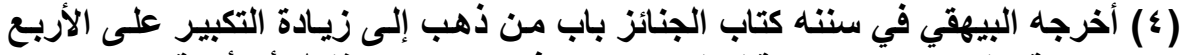

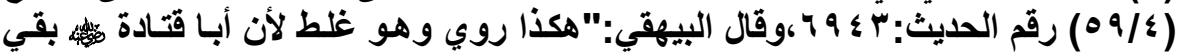

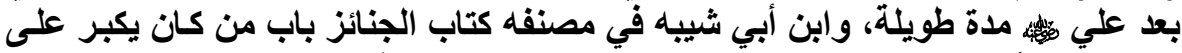

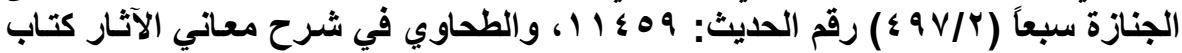

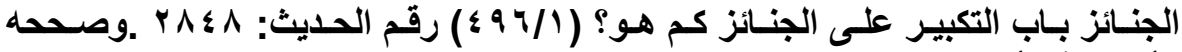

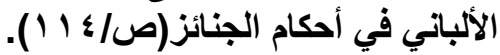

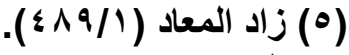

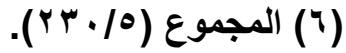

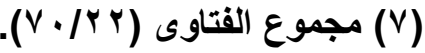
(^) ينظر: مجموع الفتاوى ( (

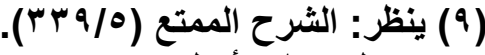

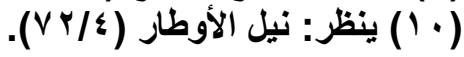


لمسألة لثانية

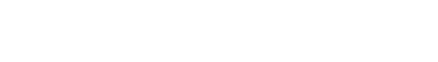

وردت السئنة في عدد التسليم في صلاة الجنازة، بصفتان:

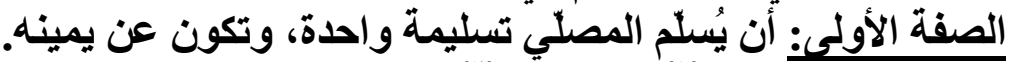

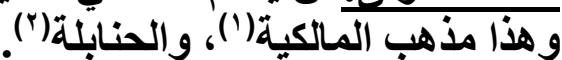
قال الإمام أحمد : "التسليم على الجنازة تسليمة واليلة واحدة، عن ستة من أصحاب

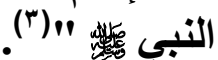

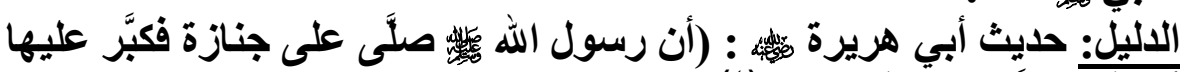

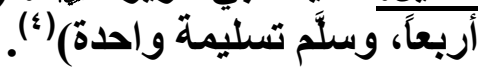
الصفة الثانية: أن يُسلم المصلي تسليمتين: تسليمة عن يمينـه، وتسليمة عن

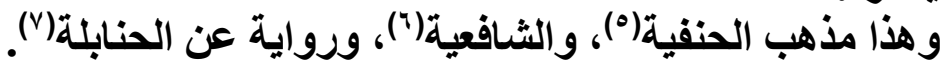

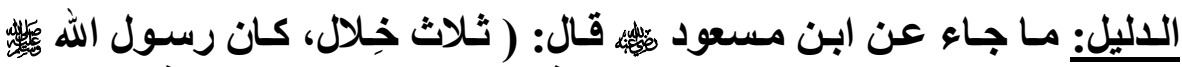

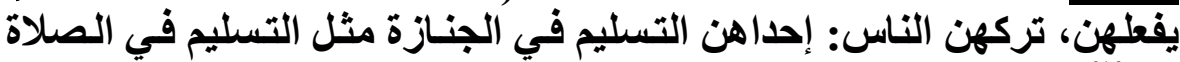
(^) $(. .$.

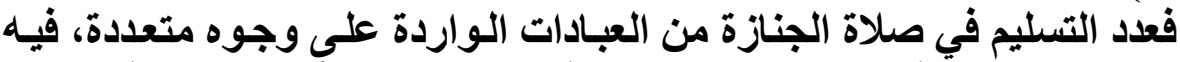

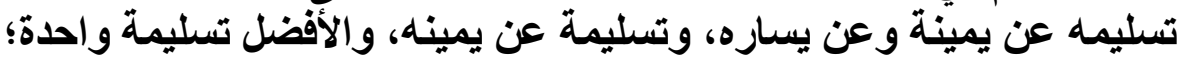

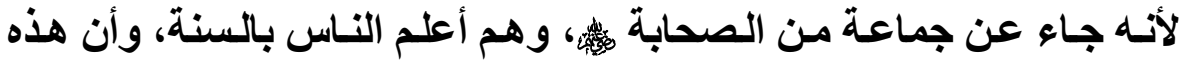

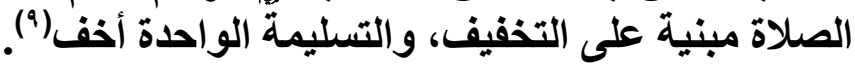

$$
\begin{aligned}
& \text { (1) ينظر: شرح مختصر خليل (r/ (19/1) (1). }
\end{aligned}
$$

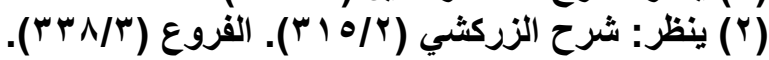

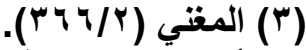

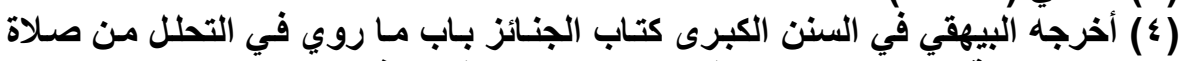

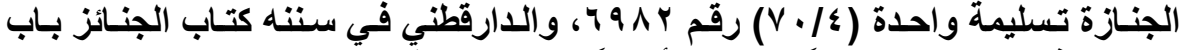

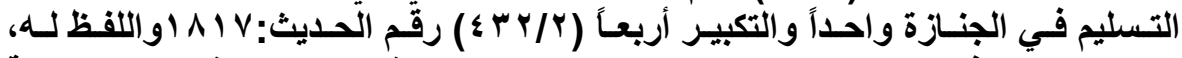

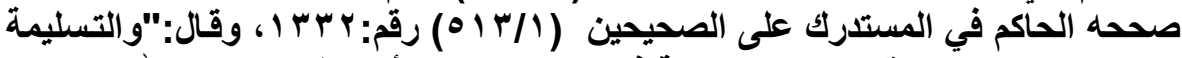

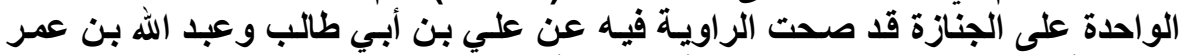

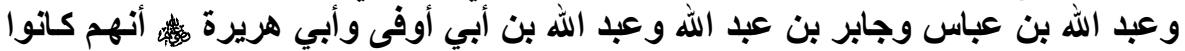

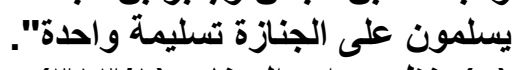

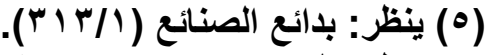

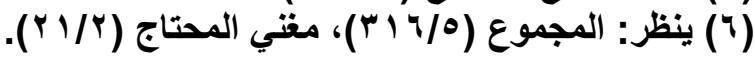
(V) ينظر: شرح الزركثي (T/Y)

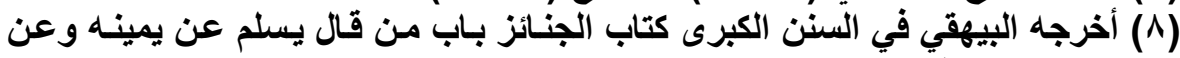

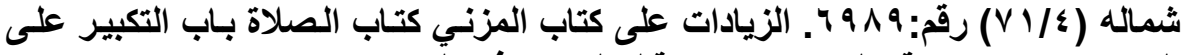

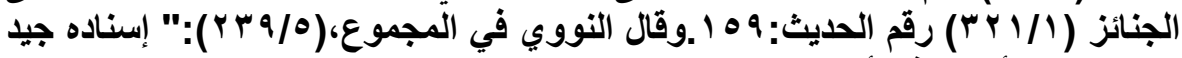

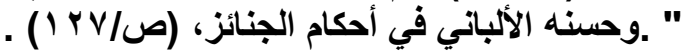

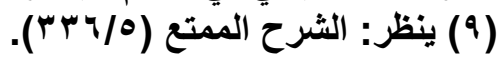




\title{
المبحث الرابـر
}

عبادات واردة على وجوه متعددة

\author{
في الصيام والدج \\ المطلب الأول \\ مسائل مز الصيام
}

المطلب الثاني مسائل مز الجج 


\section{المطلب الأول}

\section{مسائل مز الصيام}

فيه ثلا مسائل:

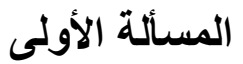

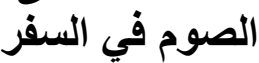

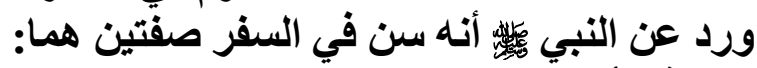
الصفة الأولى: الصوم. الصني

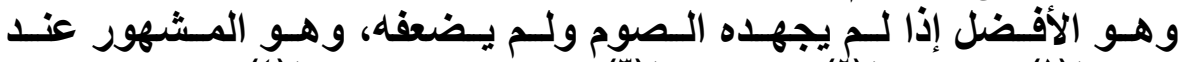

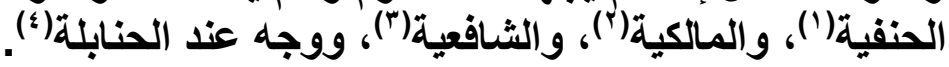

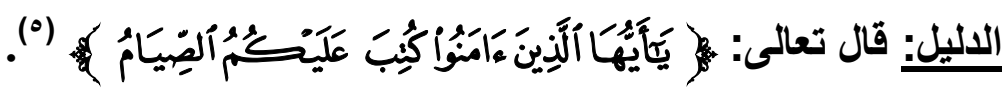

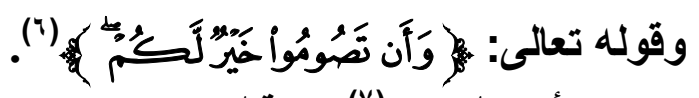

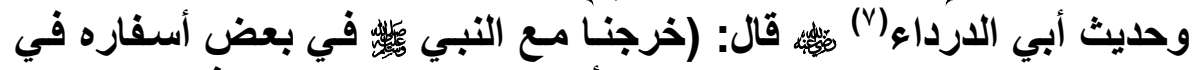

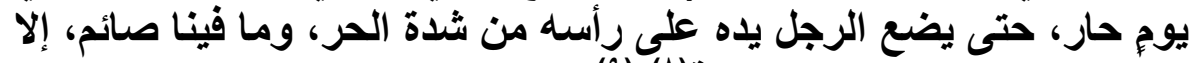

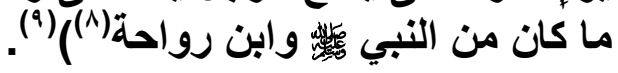

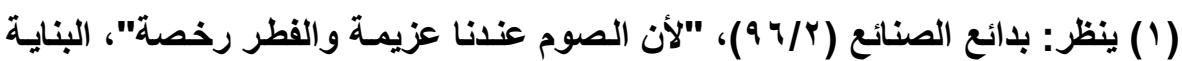

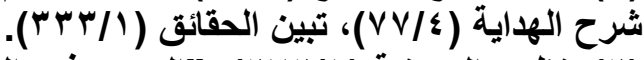

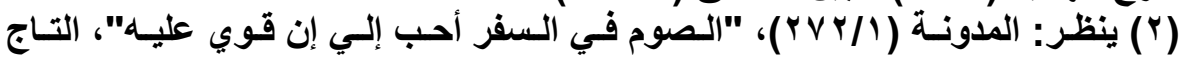

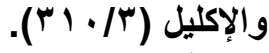

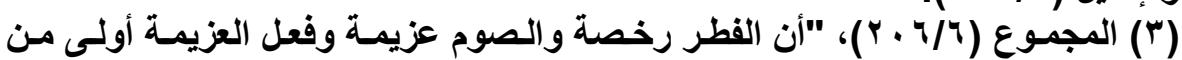

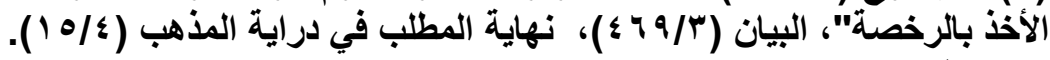

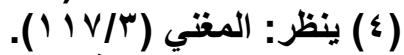

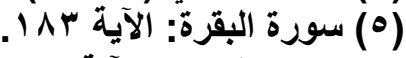

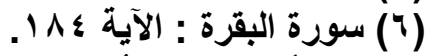

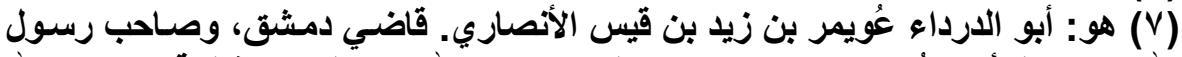

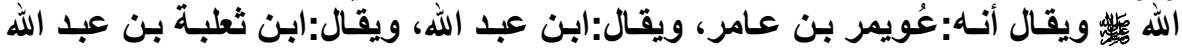

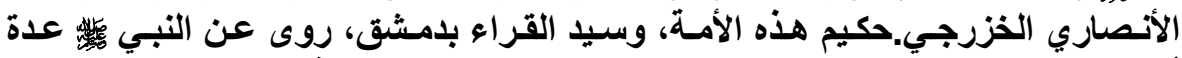

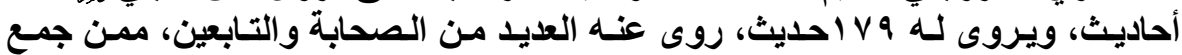

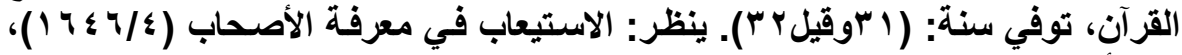

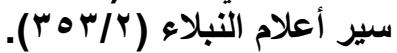

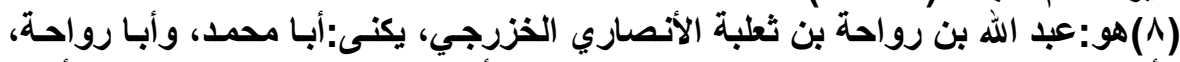

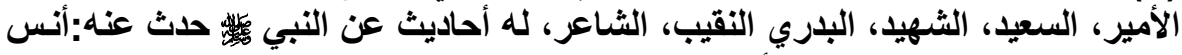

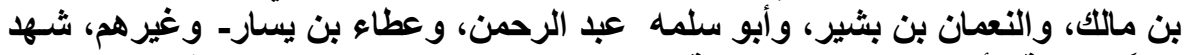

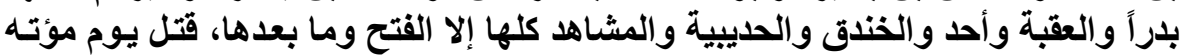

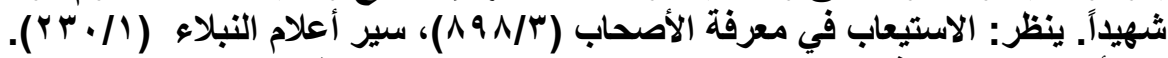

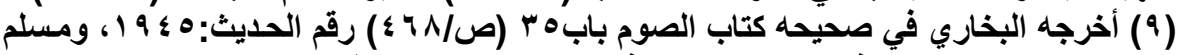

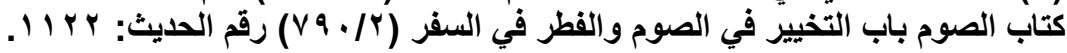


وجـه الالالـة: أن الصوم في السفر لمـن قوي عليهه ولـم يصبه منـه مشقة

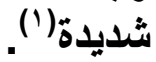
وأن الأمة تبقى مشغولة المالفرض.

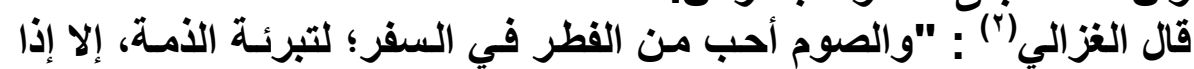

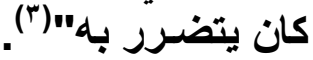

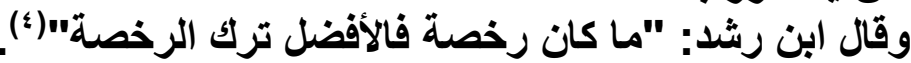
الصفة الثانية: الإفطار .

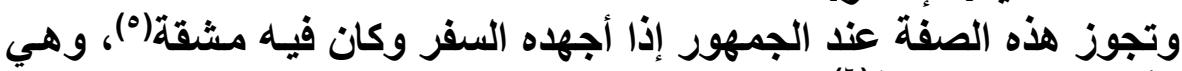
الأفضل عند الحنابلة)(").

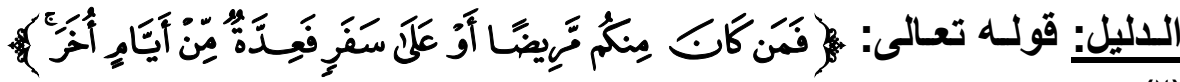

وجه الدلالة: أمر الله بالقضاء للمفطر عند وجود العذر(^).

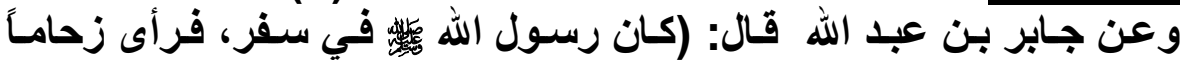

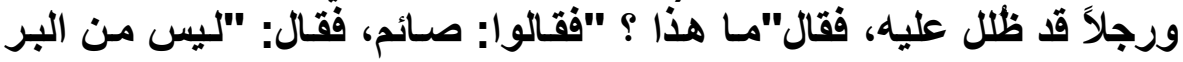

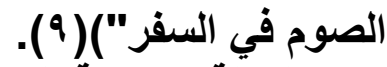

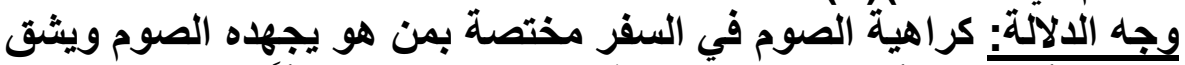

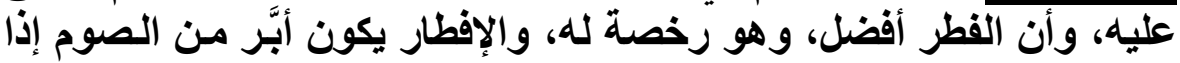

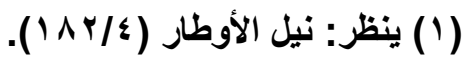

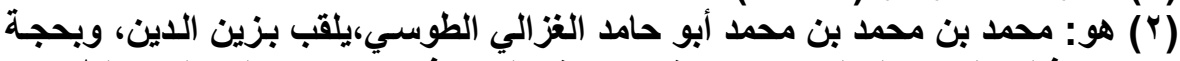

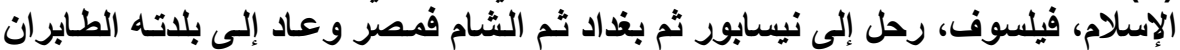

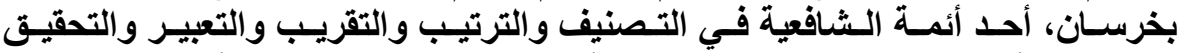

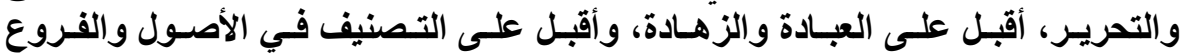

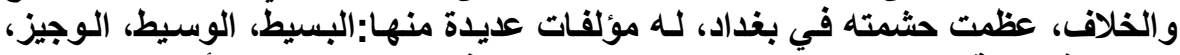

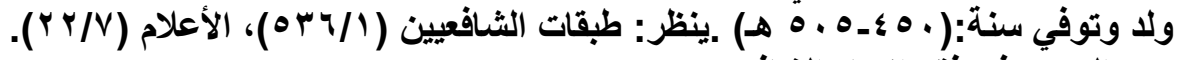

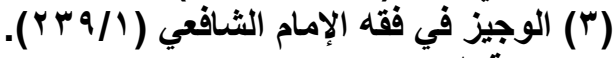

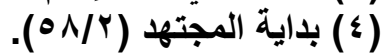

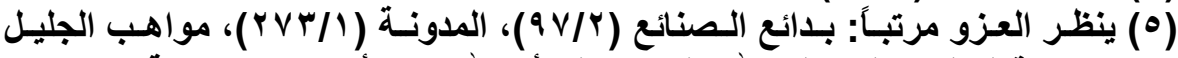

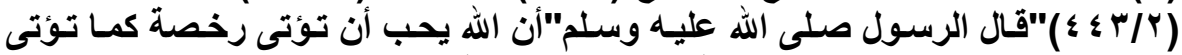

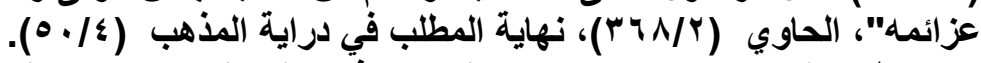

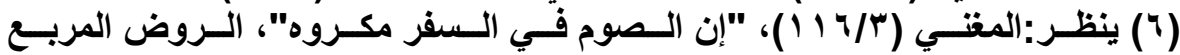
(r) (V) (^)

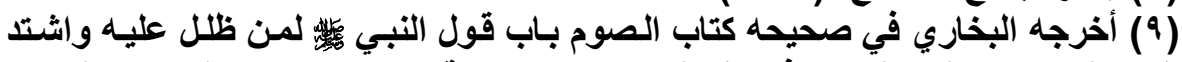

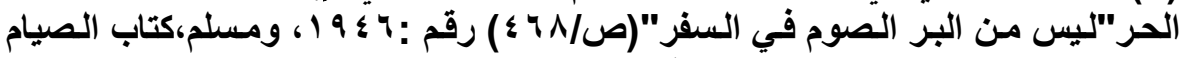

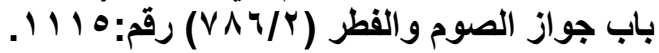


كان للتقوي وإزالة المشقة (1).

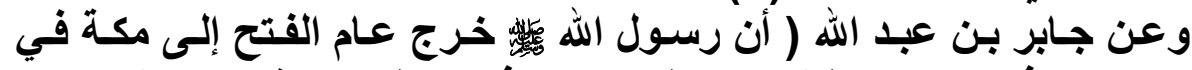

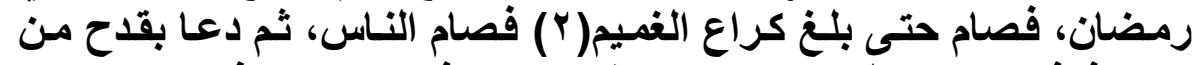

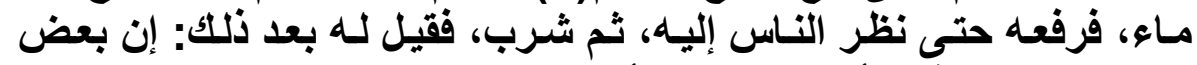

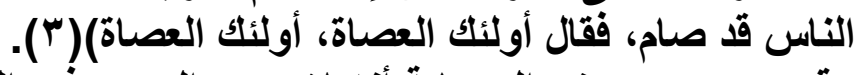

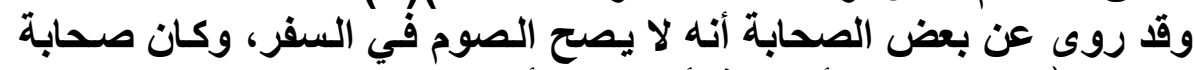

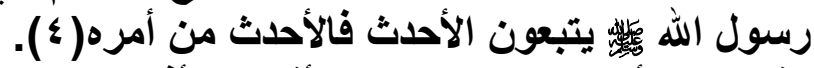

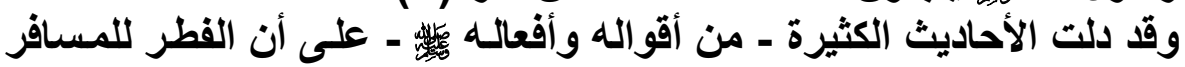
أفضل من الصوم، وجدت مشقة أو لم توجد، وأن الصيام في حقه جائز(ه).

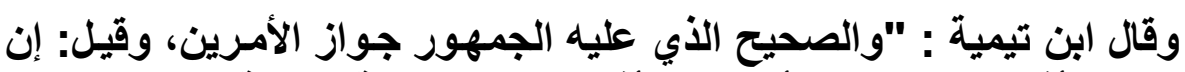

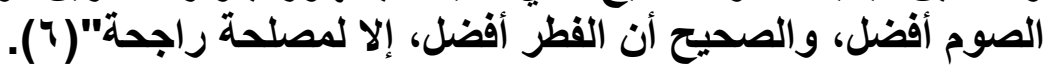

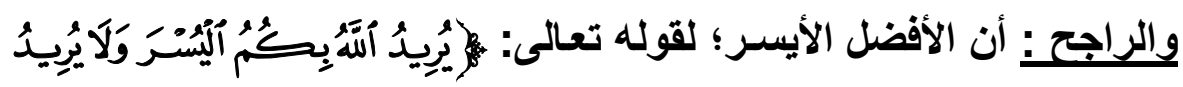

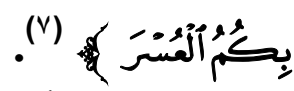
فُإن كان الفطر أيسر فهو أفضل، وإن كان الصيام أيسرَ - كمن يسهل عليه

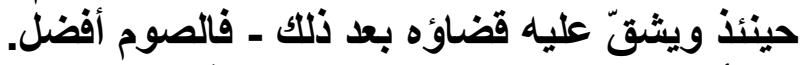

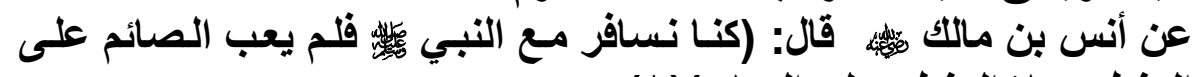
المفطر، ولا المفطر على الصائم)(^).

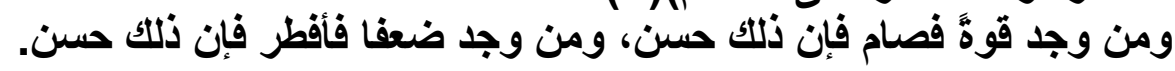

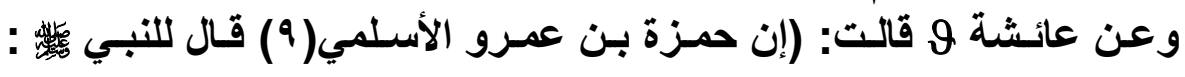

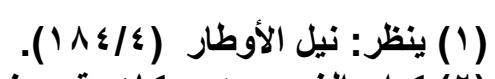

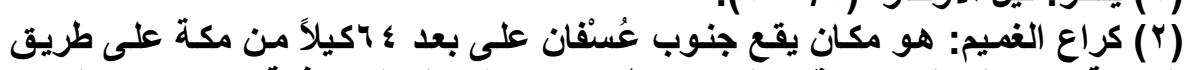

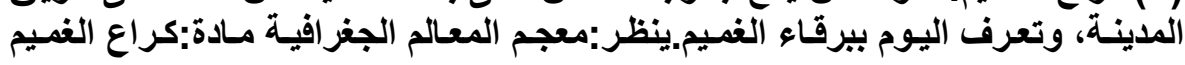

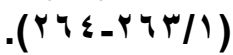

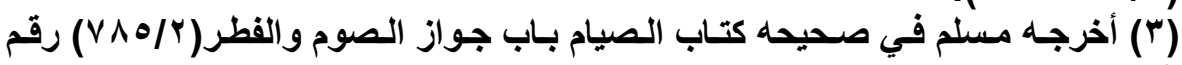

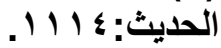

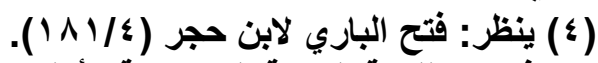

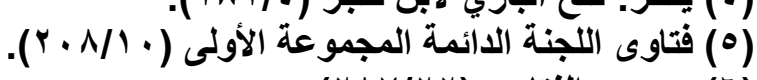

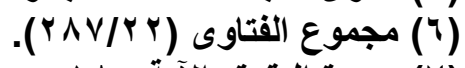

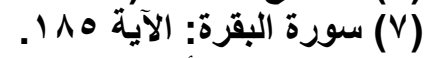
(^) متفق عليه: أخرجه البخاري في صحيحه كتاب الصوم باب لم يعب أصحاب النبي

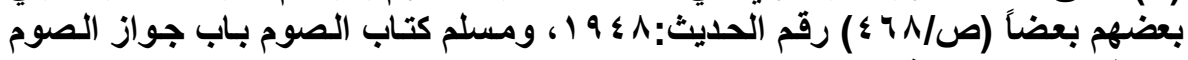

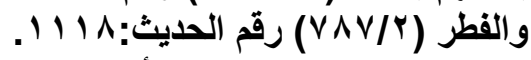

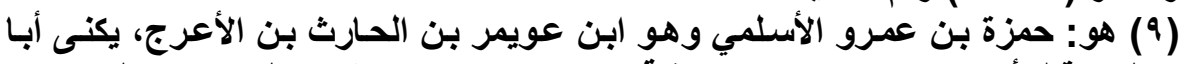

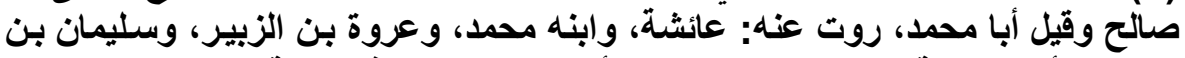

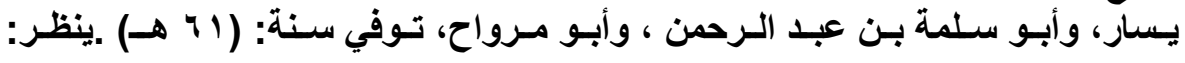


أُصوم في السفر؟ -وكـان كثير الصيام- فقـال: إن شـئت فصم، وإن شـئت فأفطر) (1) (1)

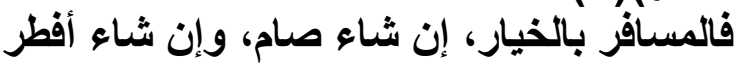

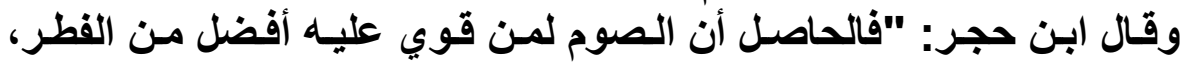

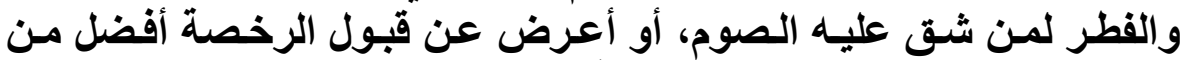

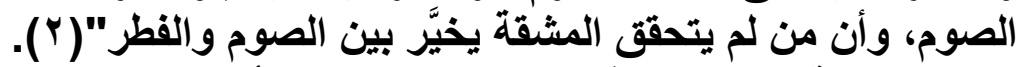

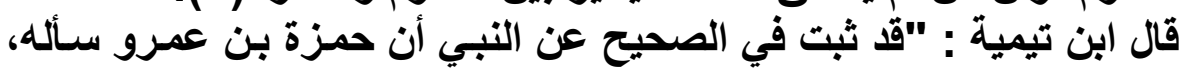

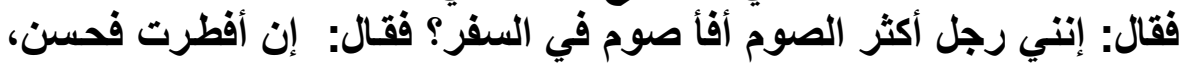

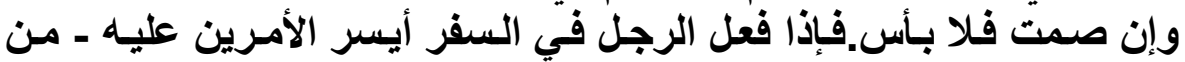

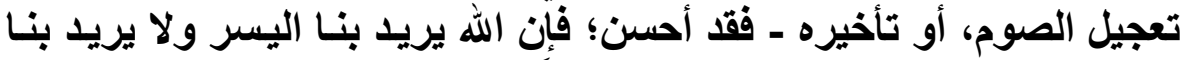

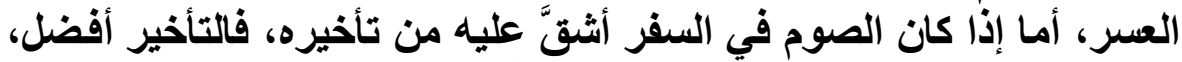

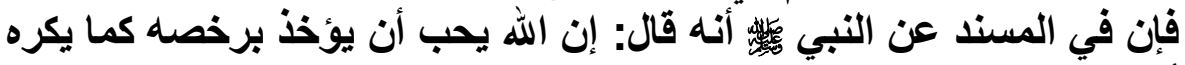

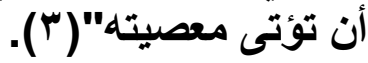

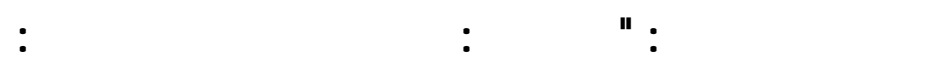

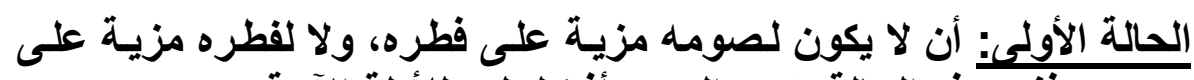

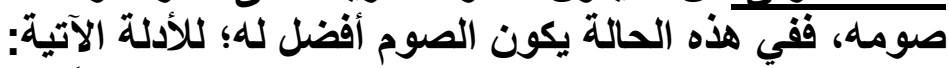

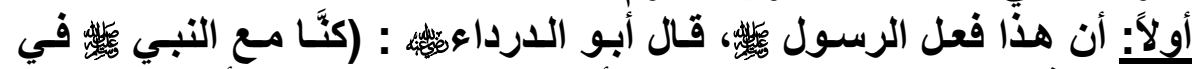

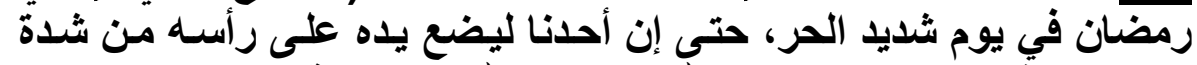

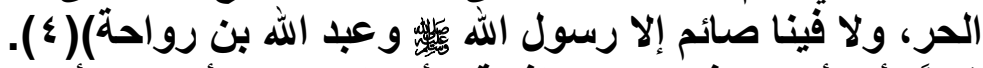

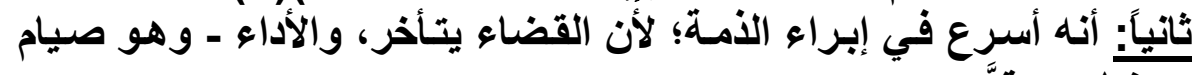

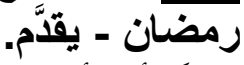

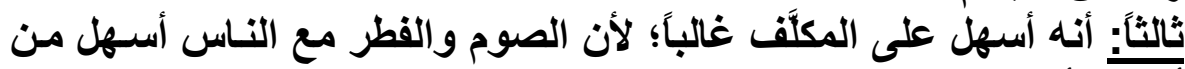

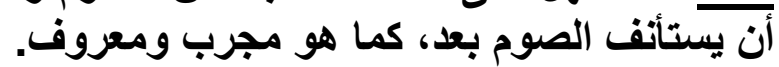

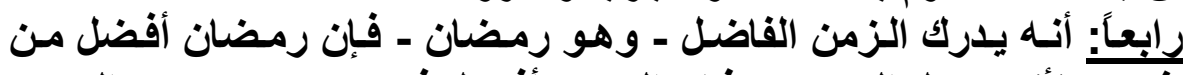

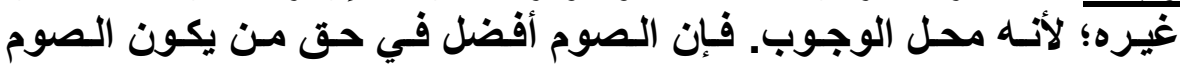
والفطر عنده سواءه.

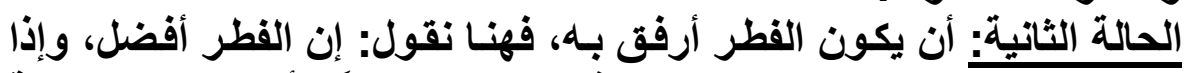

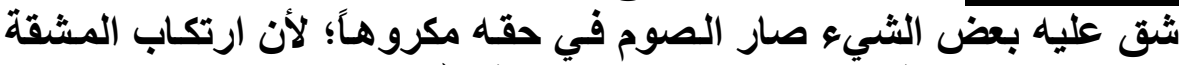

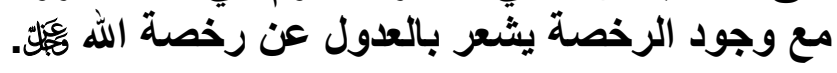

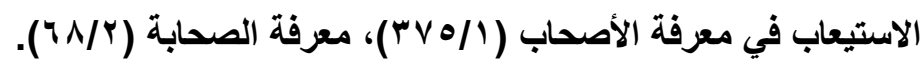

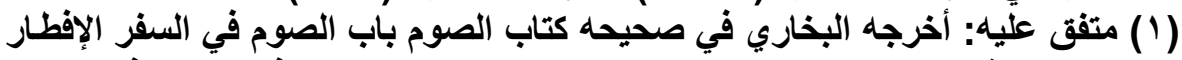

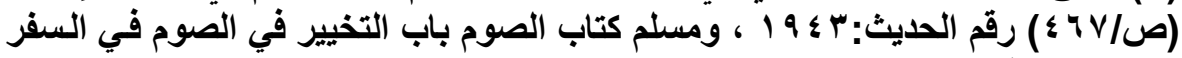

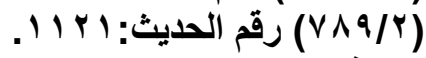
( )

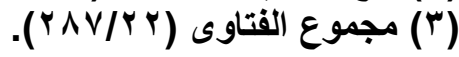
( ) سبق تخريجه (صو (1) (1) ). 
في حقلة حرامَّة. أن يشق عليه مشقة شديدة غير محتملة، فهنا يكون الصوم

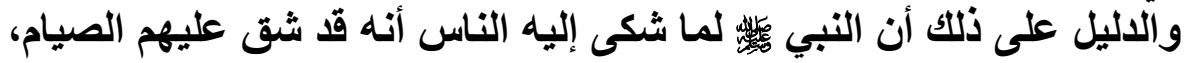

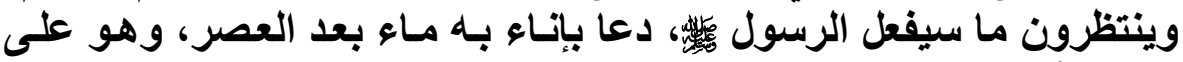

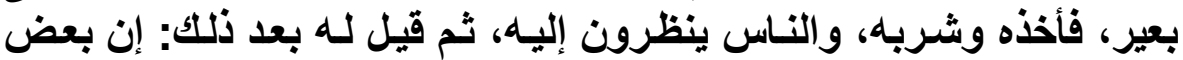

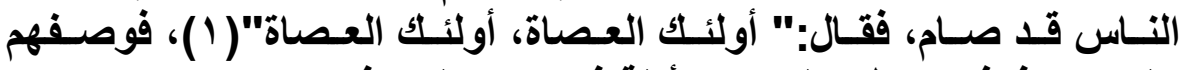

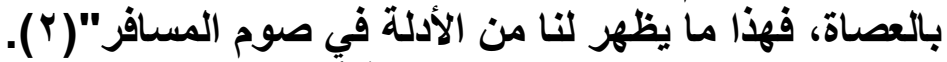

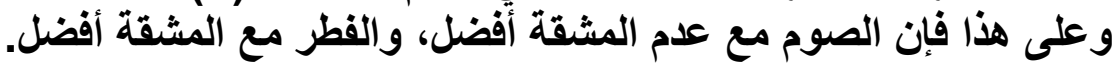
لمسألة لثانية

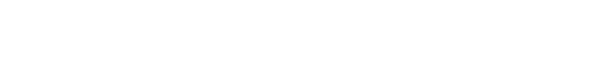

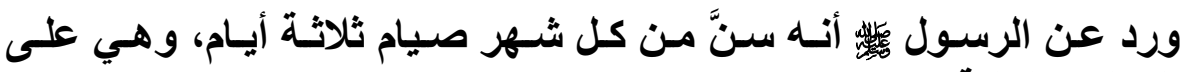

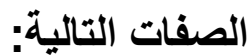

الصفة الأولىي: صيام اليوم الثالث عثر والرابع عثر والخامس عثر من كل

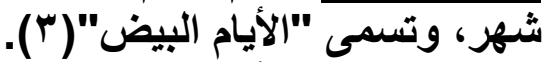

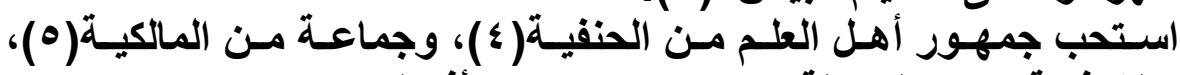

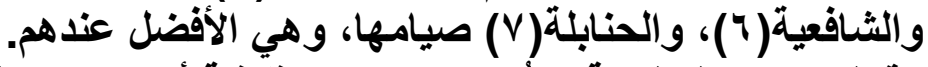

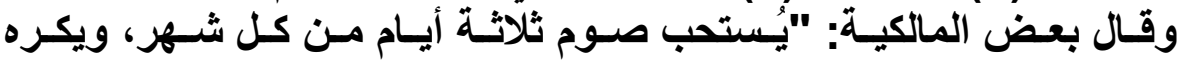

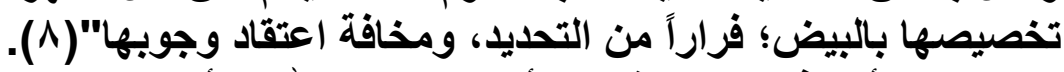

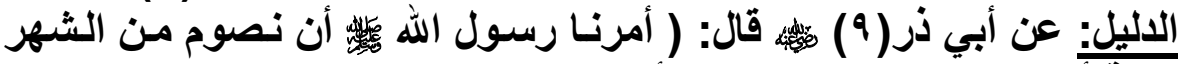
ثُلاثة أَيام البيض: ثن ثلاث عشرة، وأربع عشرة، وخمس عشرة)( • (1).

$$
\text { (1) }
$$

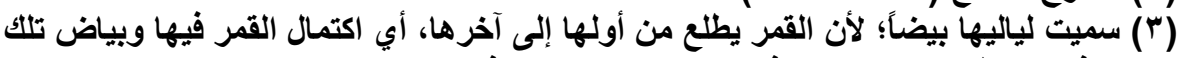

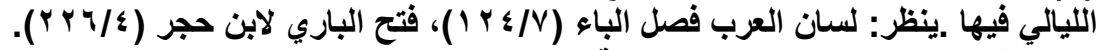

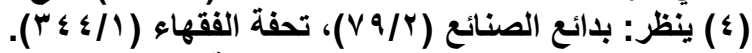

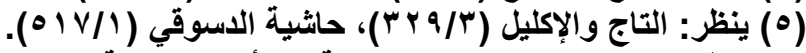

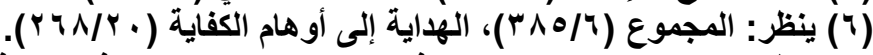

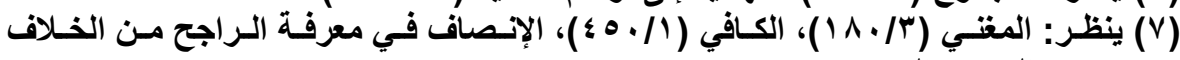

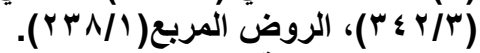

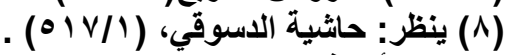

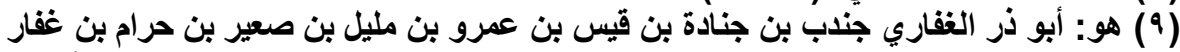

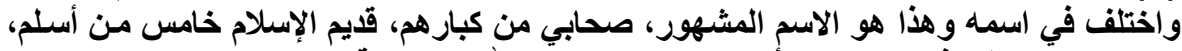

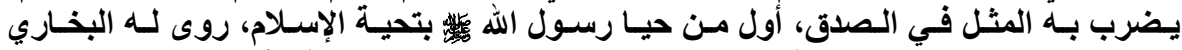

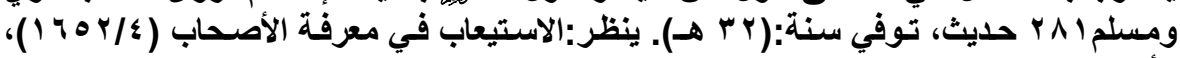

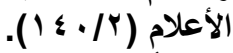

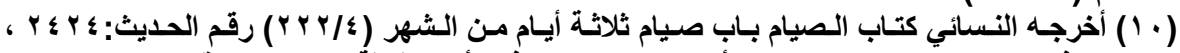

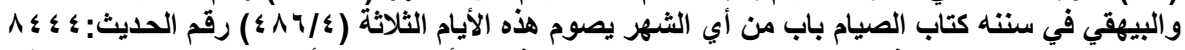

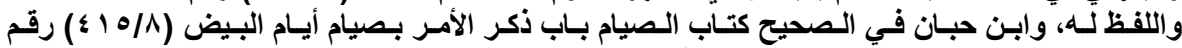

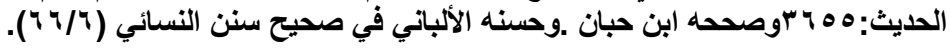




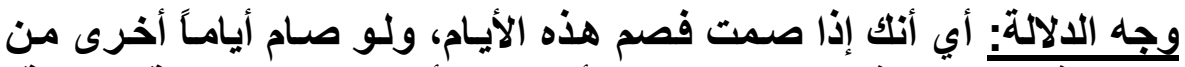

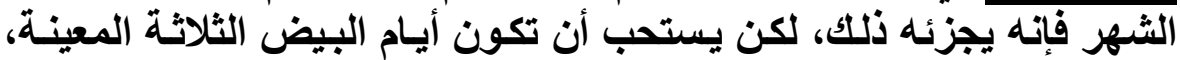
فهي على وجه الاستحباب.

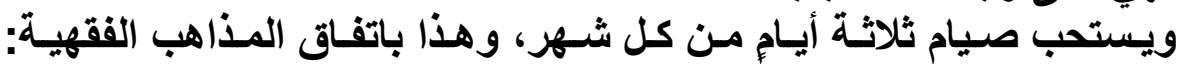

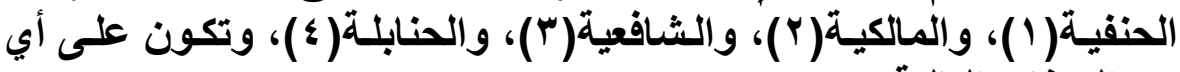

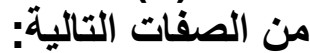

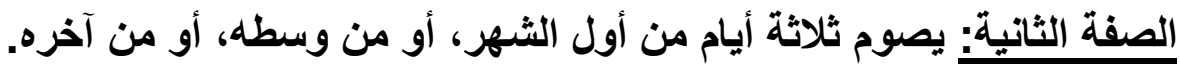

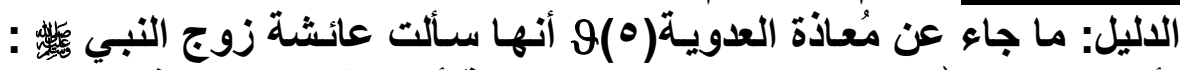

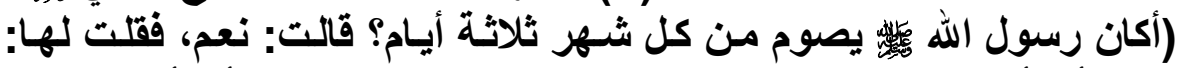

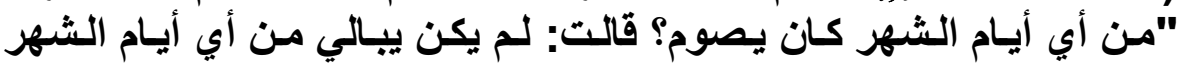

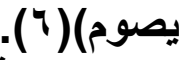

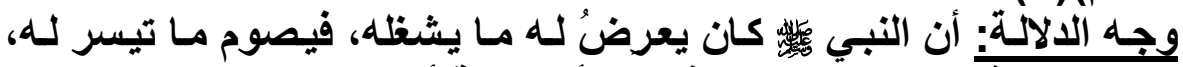

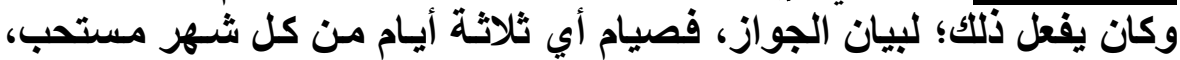

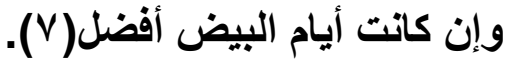

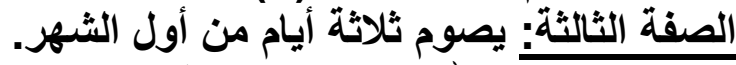

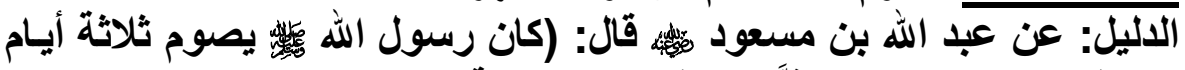

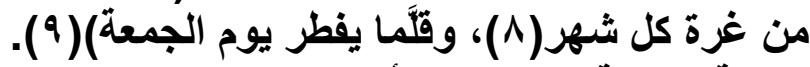

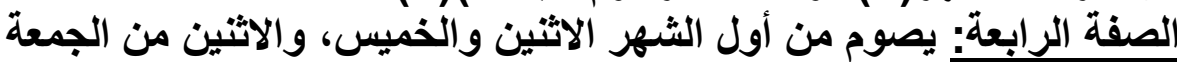

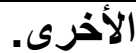

$$
\begin{aligned}
& \text { (Y) ينظر: فتح القدير (r/T • (T). }
\end{aligned}
$$

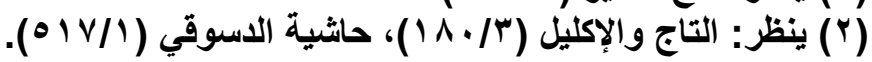

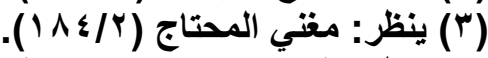

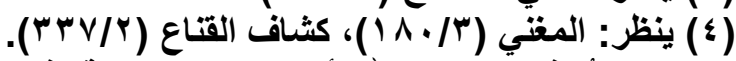

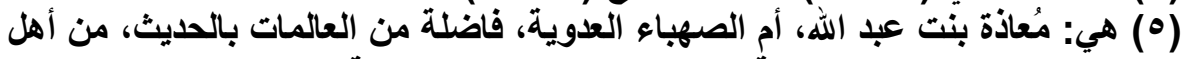

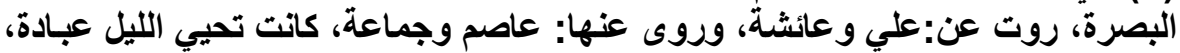

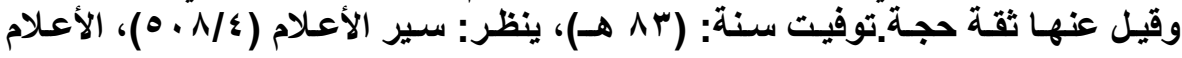
( $(r \circ 9 / \mathrm{V})$

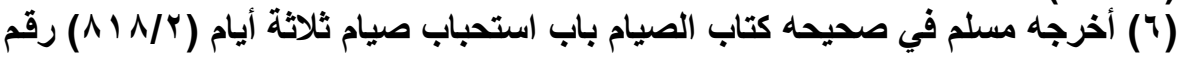

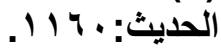

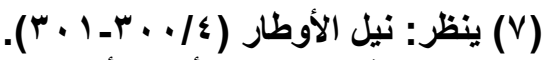

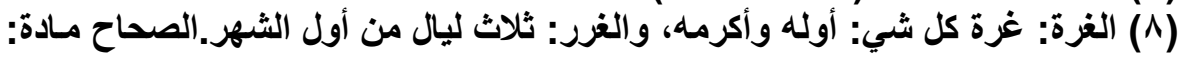

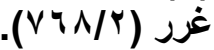

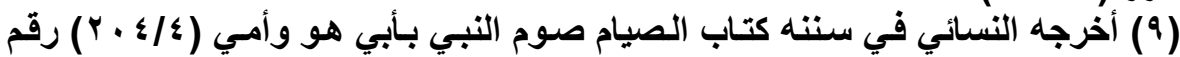

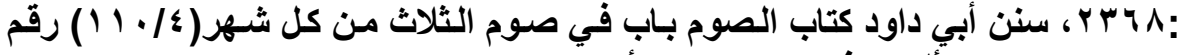

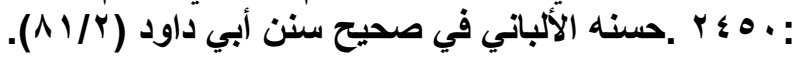




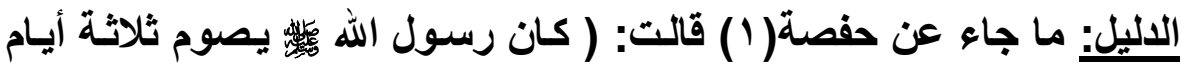

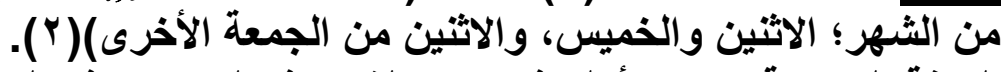

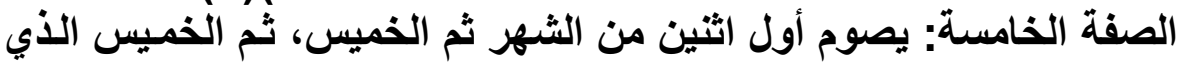

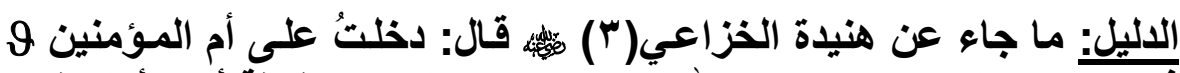

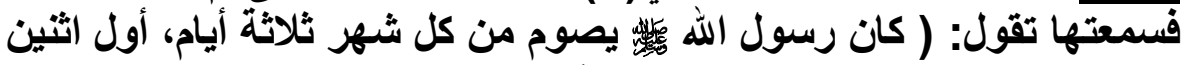

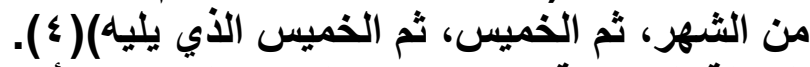

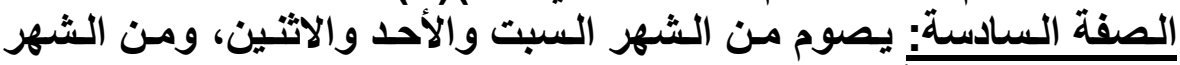

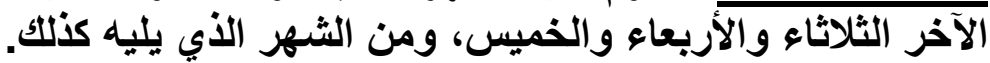

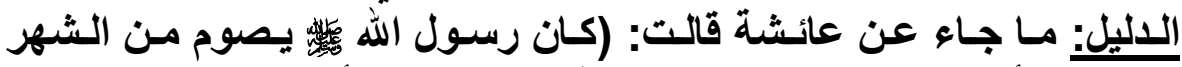

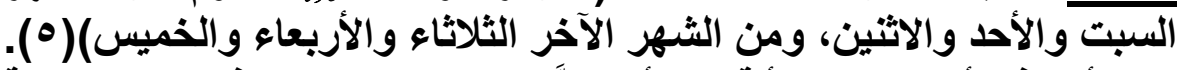

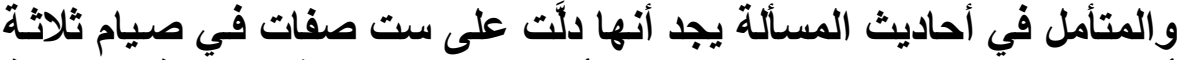

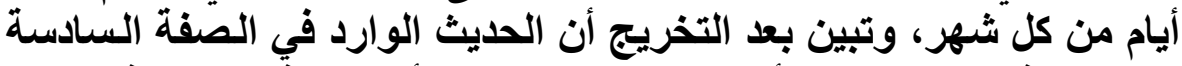

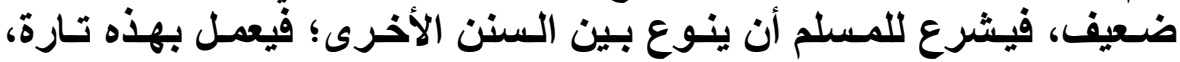

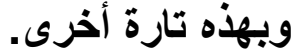

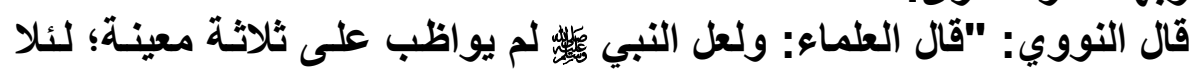

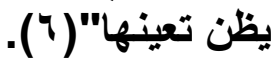

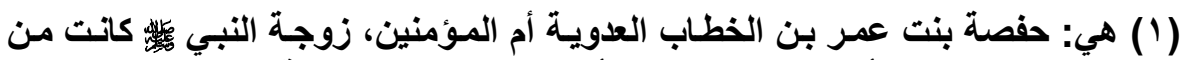

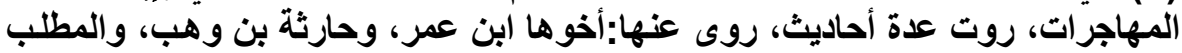

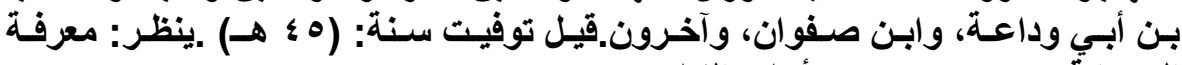

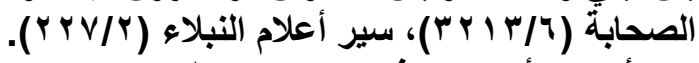

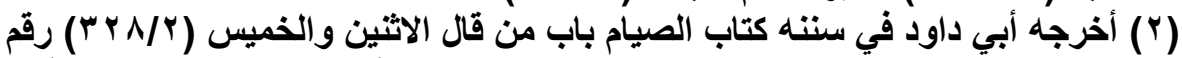

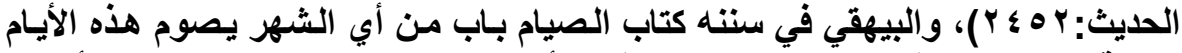

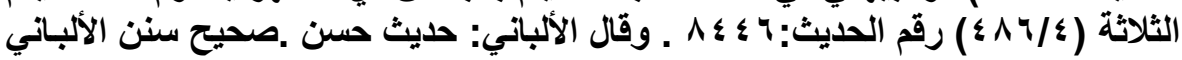

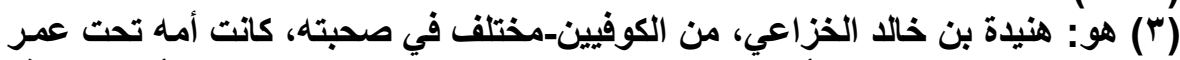

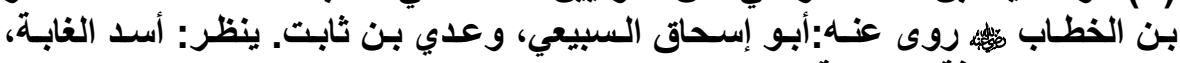

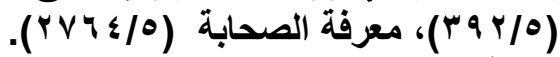
(؛) (أخرجه النسائي في سنته كتاب الصيام باب كيف يصوم ثُلاثة أيام من كل شـهرج

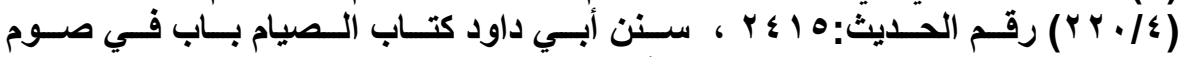

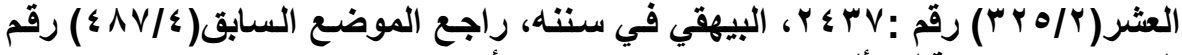

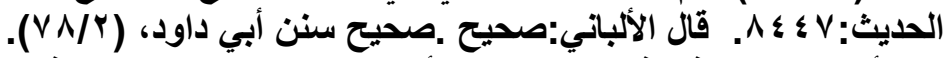

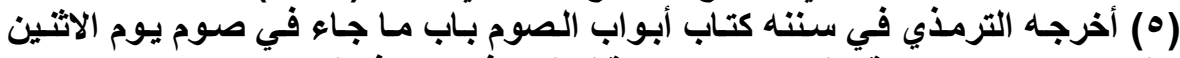

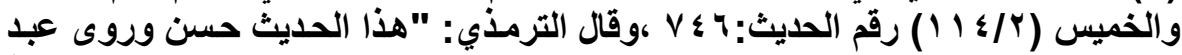

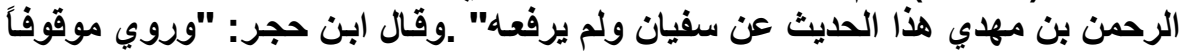

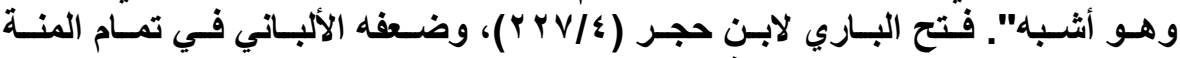

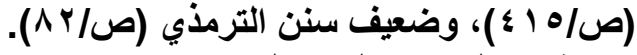

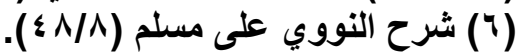


وقـال الشوكاني: "فيكون الصائم مخيراً، وفي أي وقت صـامها فقد فعل

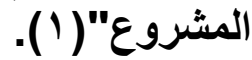
وقتال ابن حجر: "كان يفعل ذلك لبيان الجواز، وكل ذلكت في حقهـ أفضل، وتترجح البيض بكونها وسط الثهر، ووسط الثيء الثيء أعلده" (؟).

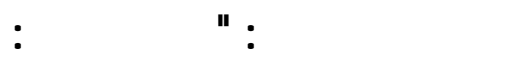

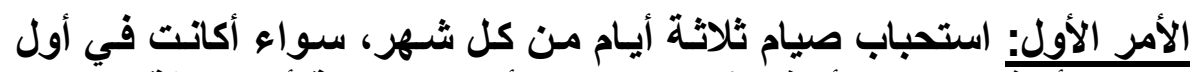

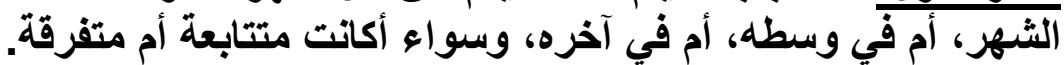

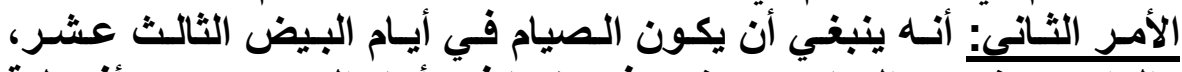

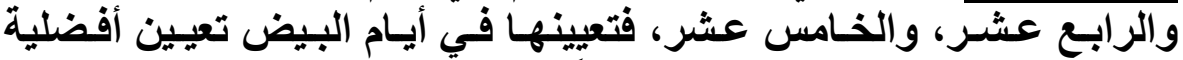

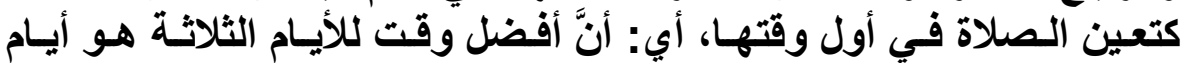

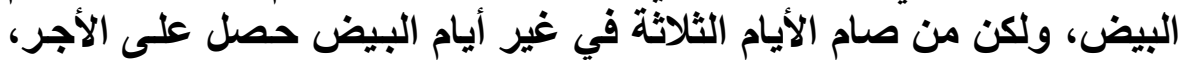

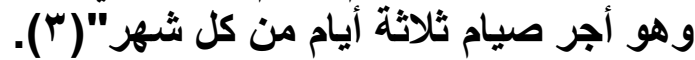

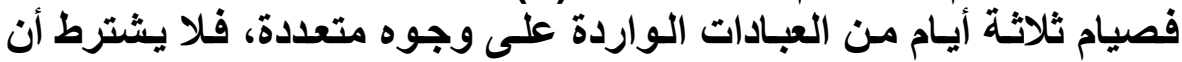

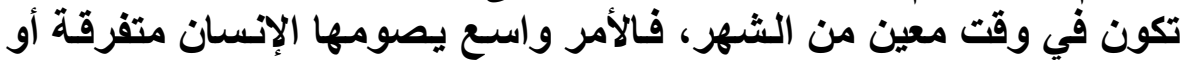
متوالية، فكله جائز ومباح، إلا أن الإكثار من صيام أيام البيض أولى؛ لوجوه

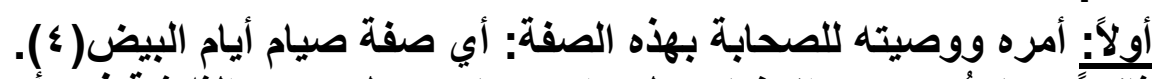

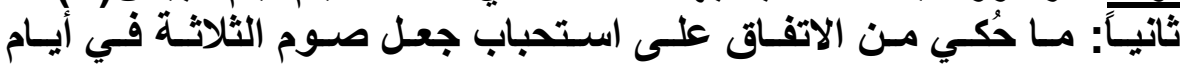

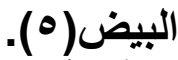

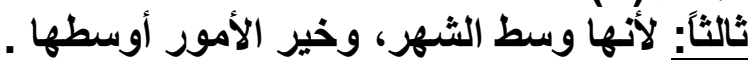
رَابعاً: أن صيام أيام البيض يختص، بفائدة طبية_كما قيل-والله أعلم(ج). (؛) قال ابن حجر: "والأي يظهر أن الذي أمر به وحث عليه ووصى به أولى من غيره،

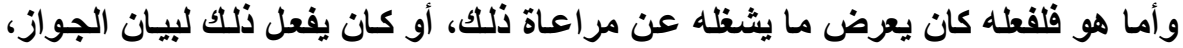

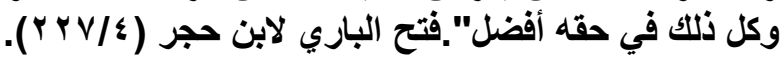

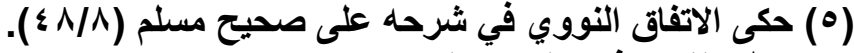

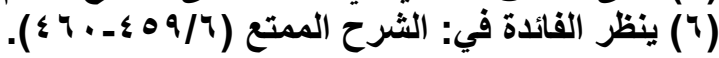




\section{لمسألة لثالثة}

\section{صفة صيا يـ علث الثاله (1)}

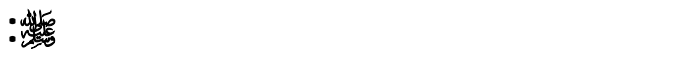

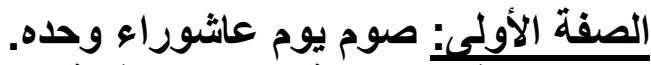

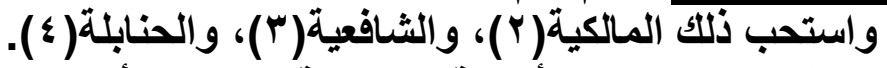

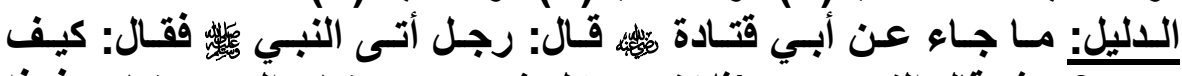

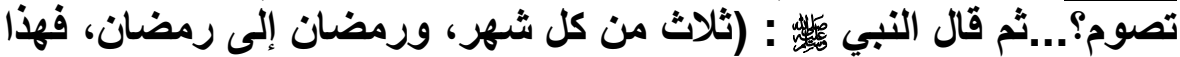

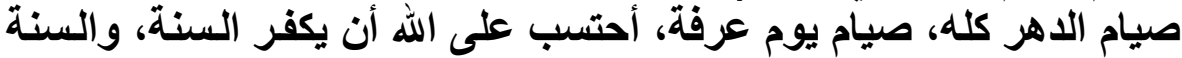
التي بعده، وصيام يوم عاثـوراء، أحتسب على الله أن يكفر السنة التي

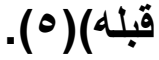

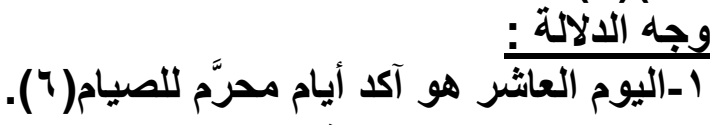

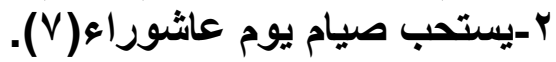

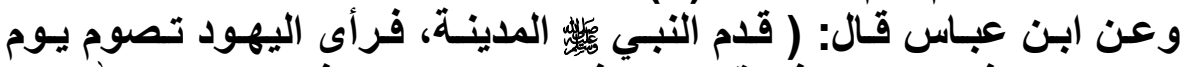

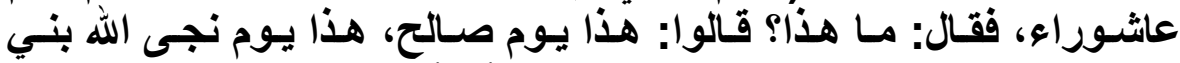

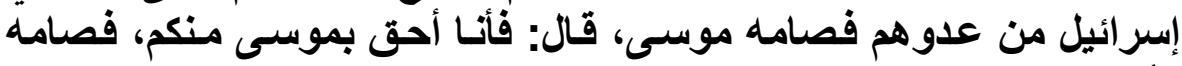
وأمر بصيامه) (^) (^).

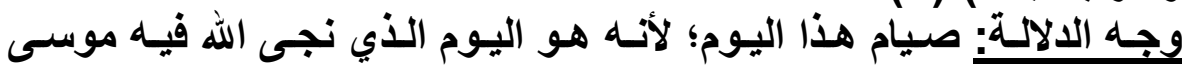

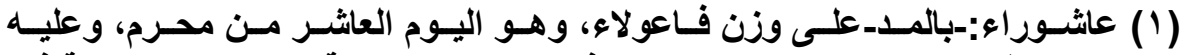

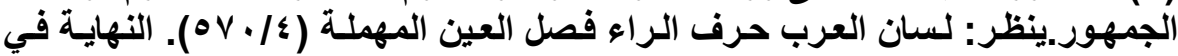

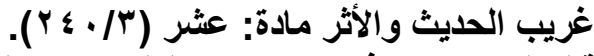

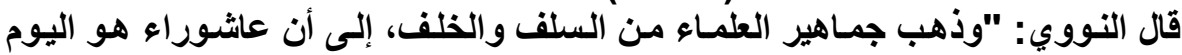

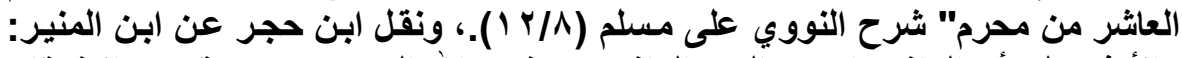

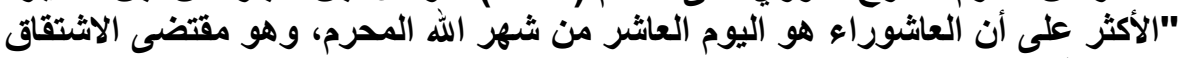

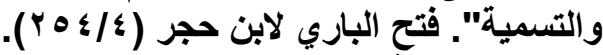

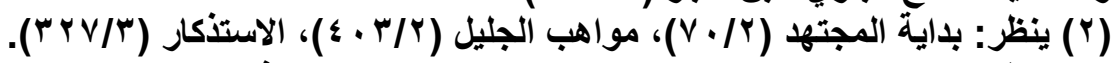

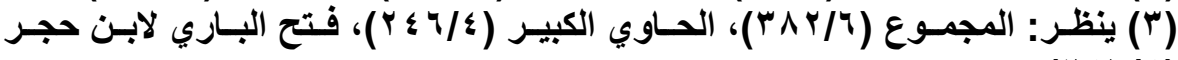
( $(Y \leq T / \varepsilon)$

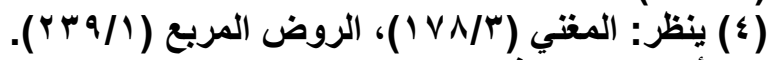

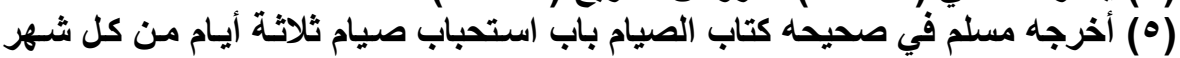

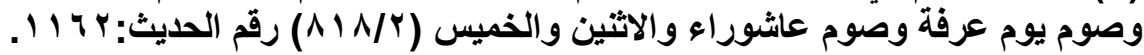

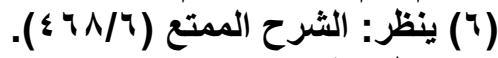

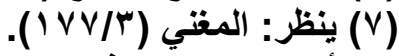

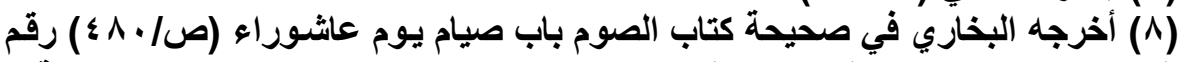

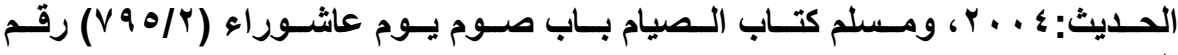


وقومه، والتوقيت بالأهلة وليس بالأشهر الإفرنجيه (1).

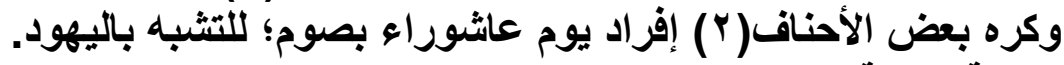

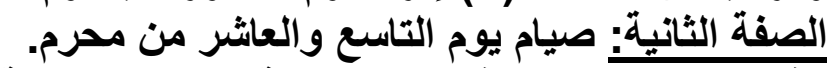

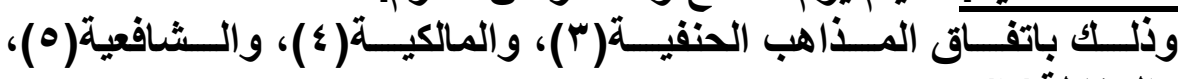
والحنابلة (7).

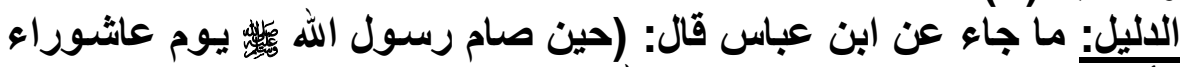

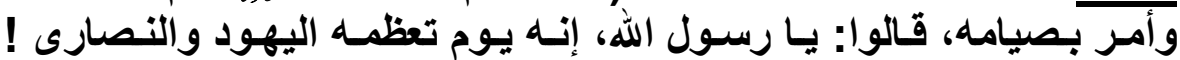

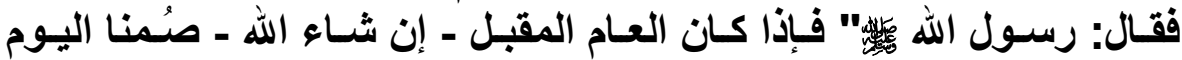

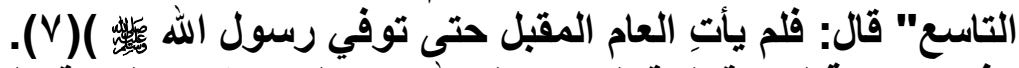

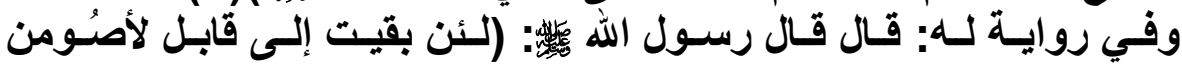

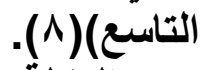

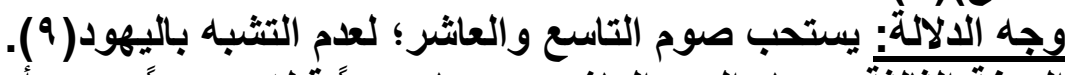

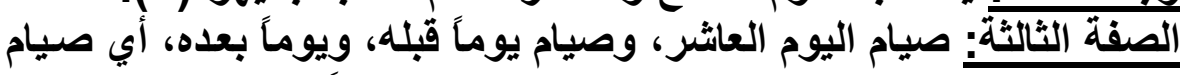

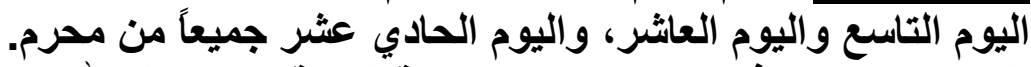

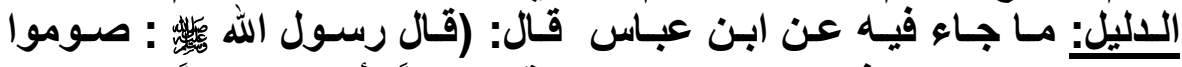

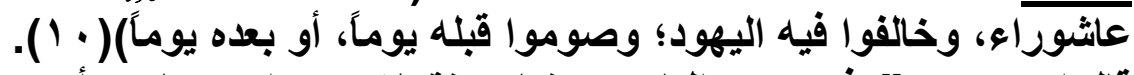

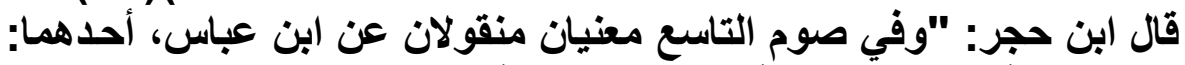

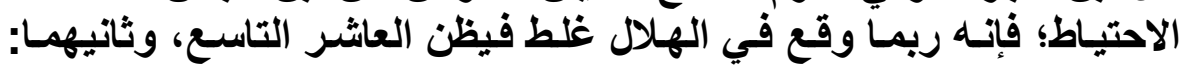

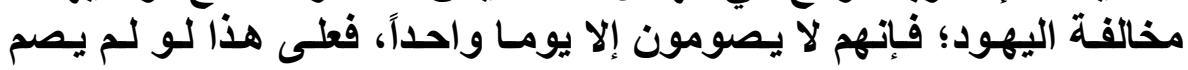

$$
\begin{aligned}
& \text { (1) ينظر: الثرح المتع (Y/7 (Y/7). }
\end{aligned}
$$

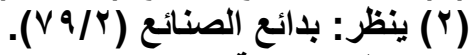

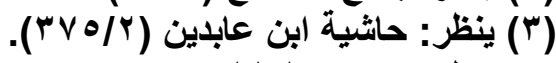

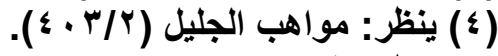

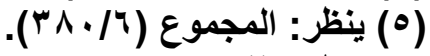

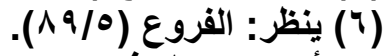

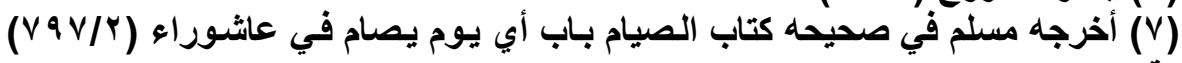

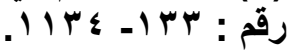

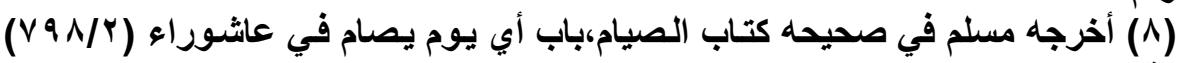

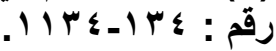

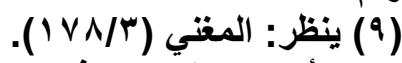

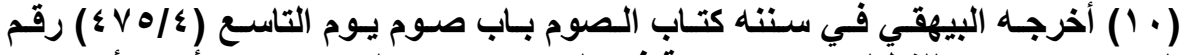

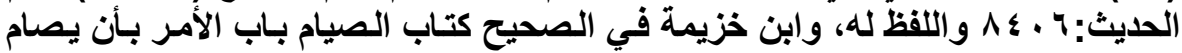

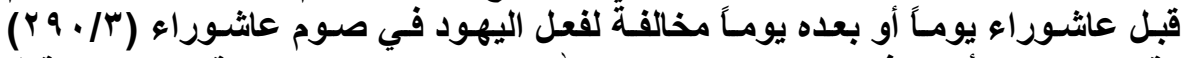

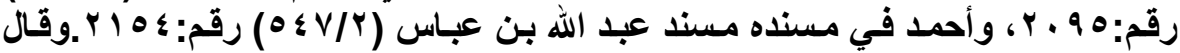

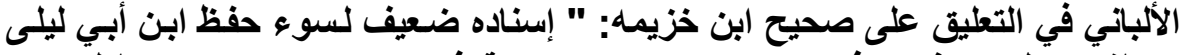

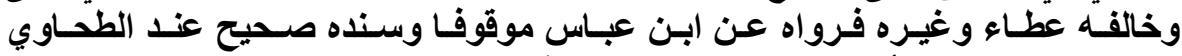

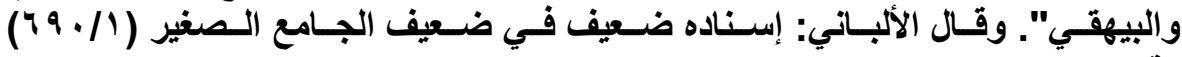




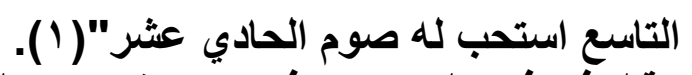

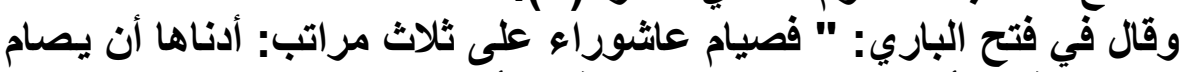

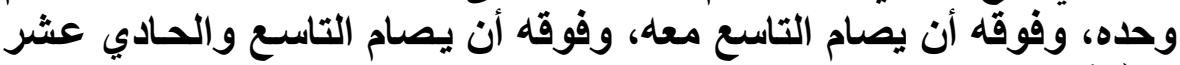

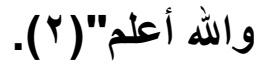

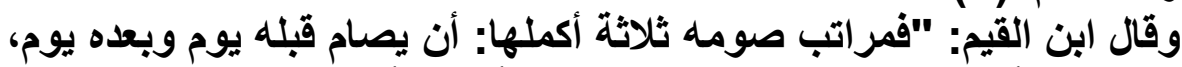

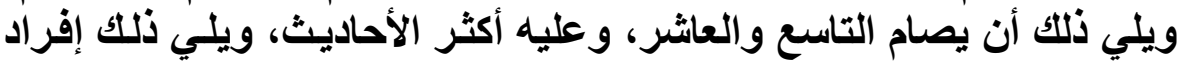

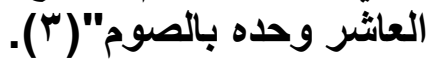

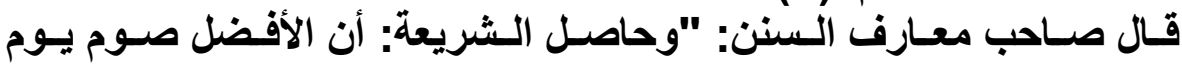

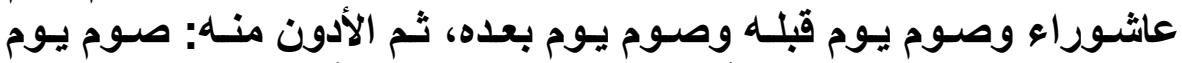

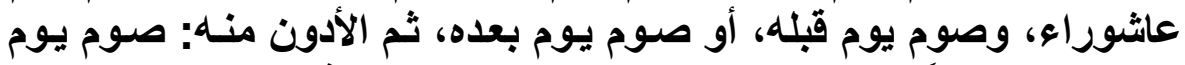

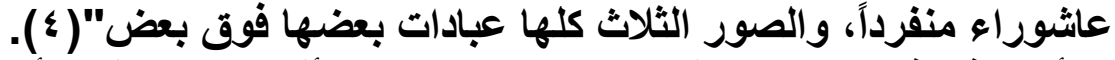

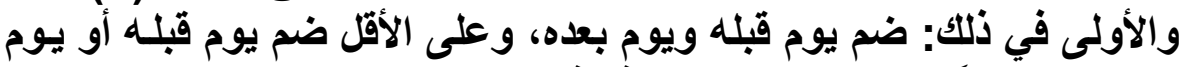

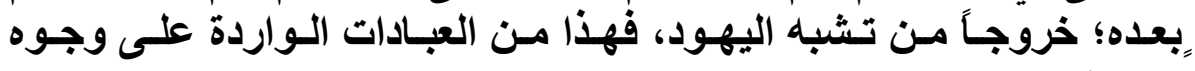

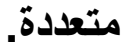

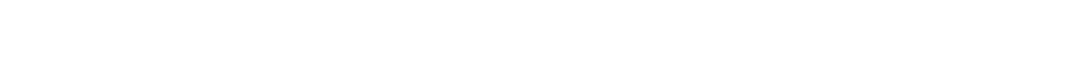

منها:

الأول: لأن فيه مخالفة لليهود في اقتصار هم على صوم عاثوراء.

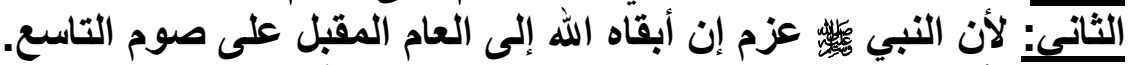

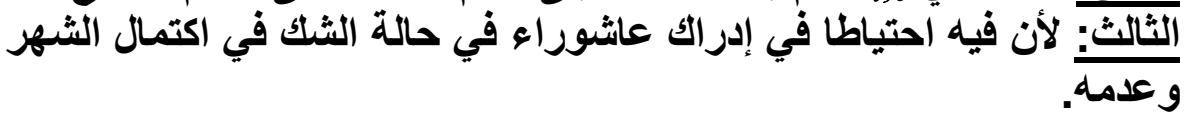

\section{المطلب الثاني \\ مسائل من العج}

فيه ثلا مسائل:

لمسألة لأ له

لفا لتلبية

ورد في ألفاظ التلبية صفات، هي:

الصفة الأولى: لبيك اللهم لبيك، لبيك لا شريك للك لبيك، إن الحمد والنعمة لك و والملك لا شريك للك. 


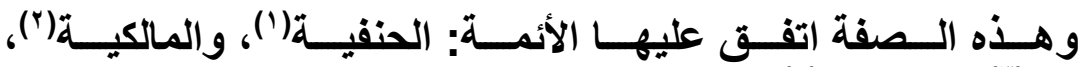

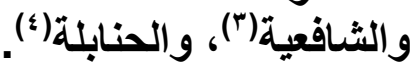

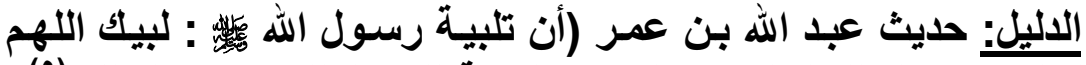

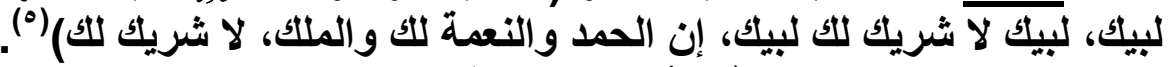

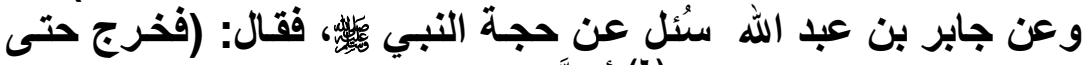

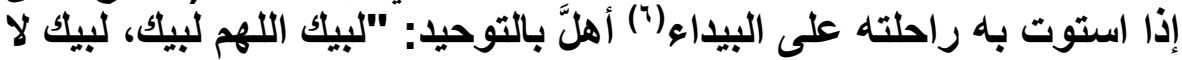

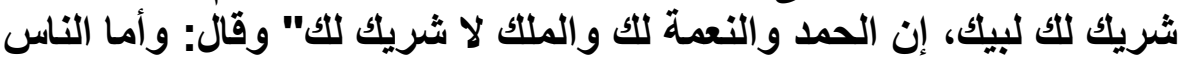

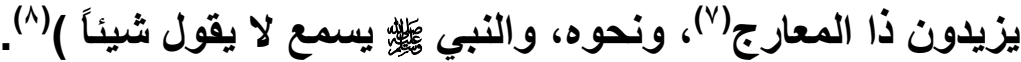

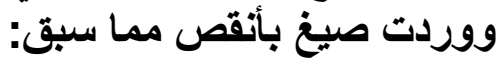

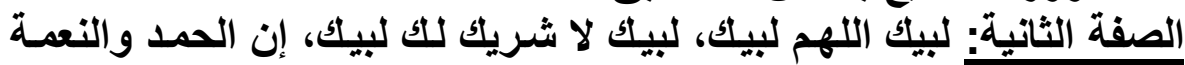
لك.

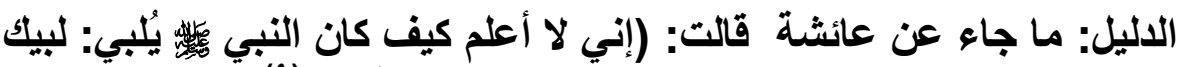

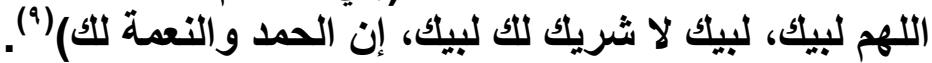
الصفة الثالثة: لبيك إلئَ الحق لبئ لبيك.

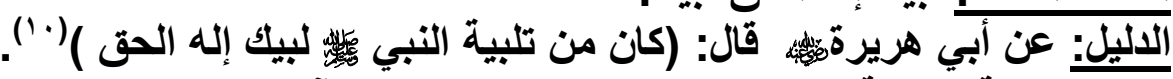

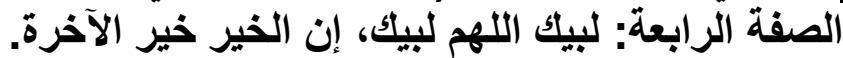

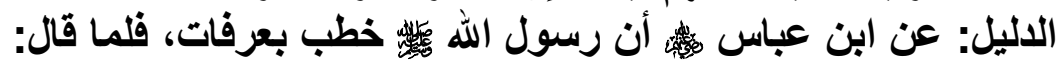

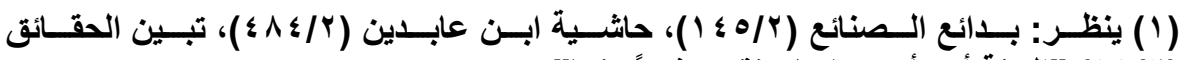

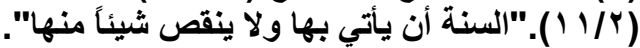

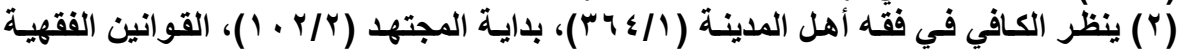
. (AN/l)

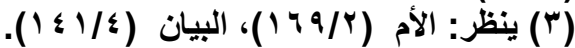

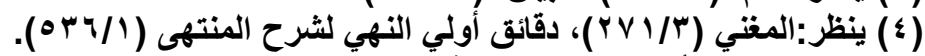

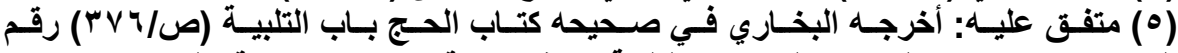

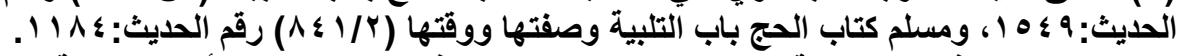

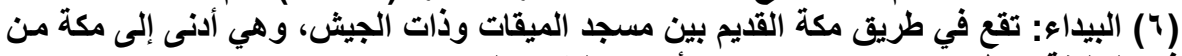

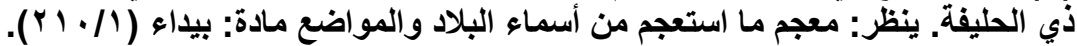

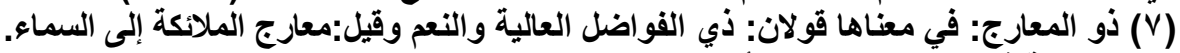

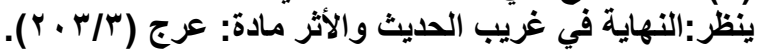

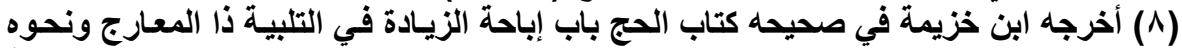

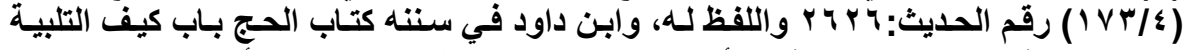

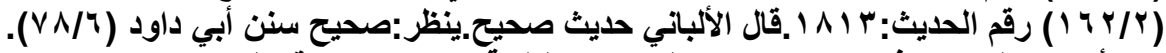

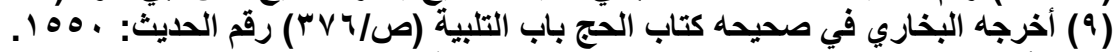

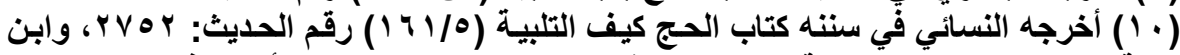

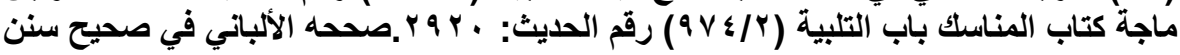

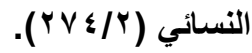


(لبيك اللهم لبيك قال: إنما الخير خير الآخرة) (').

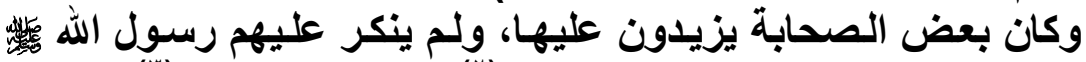

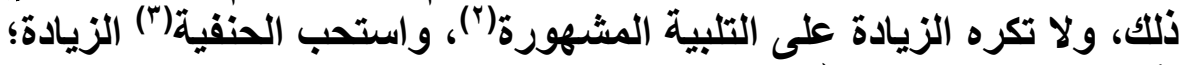

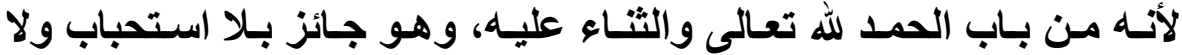

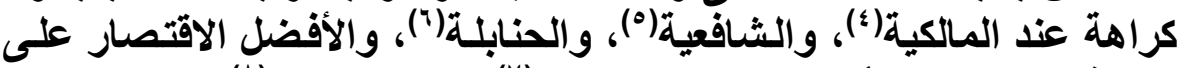

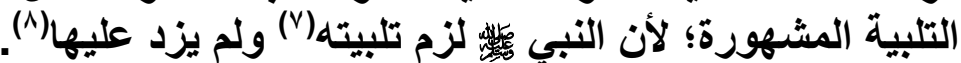

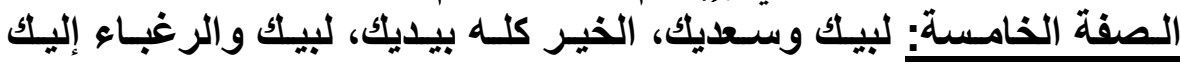

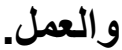

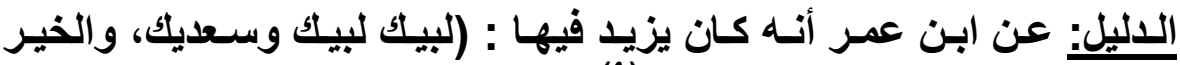

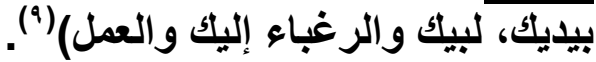

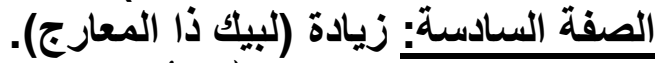

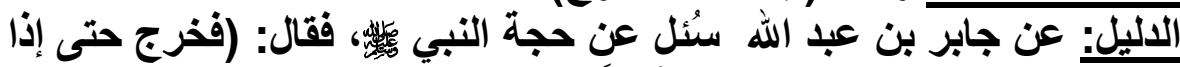

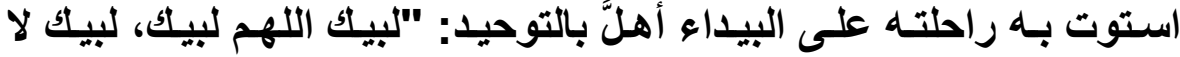

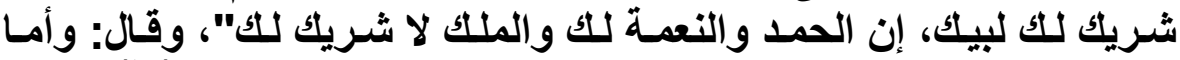

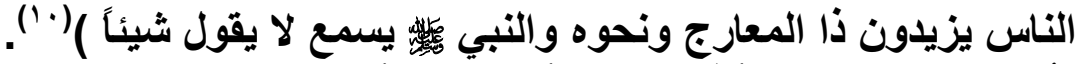

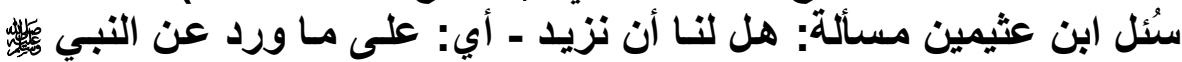

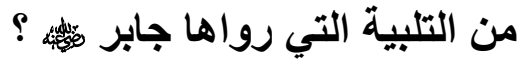

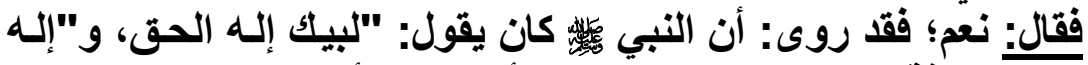

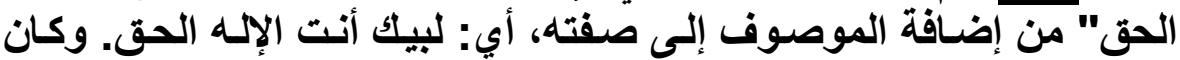

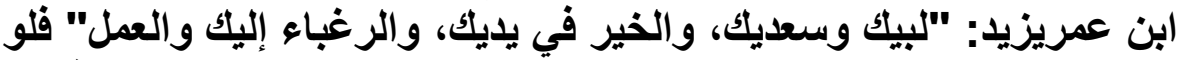

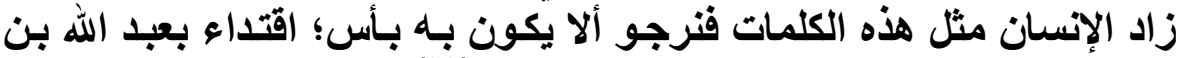

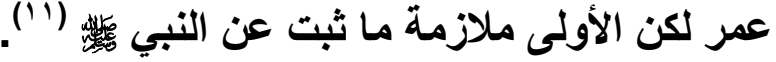

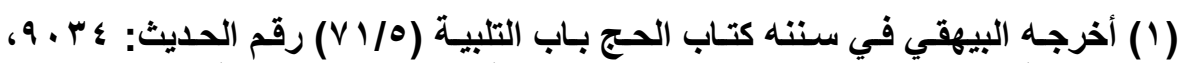

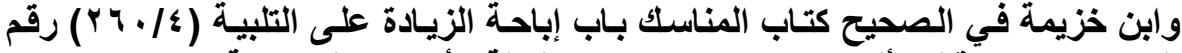

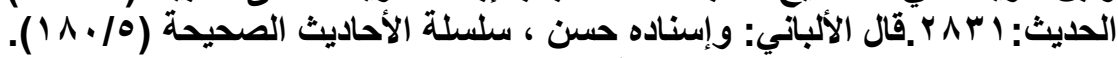

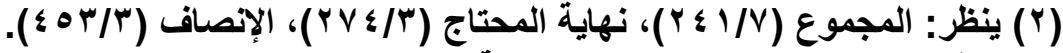

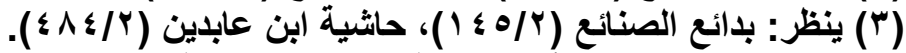

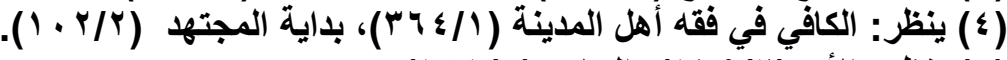

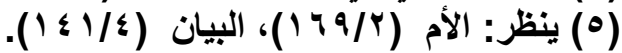

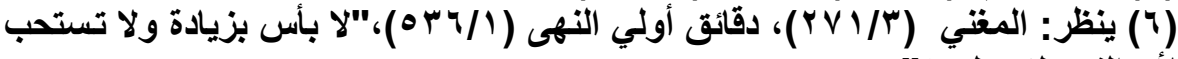
لأن النبي لزم تلبيته".

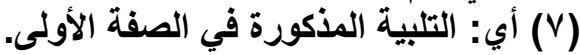

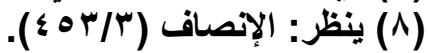

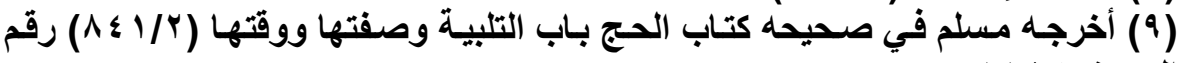

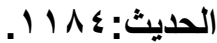

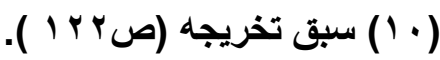

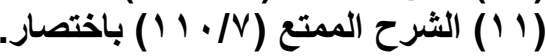




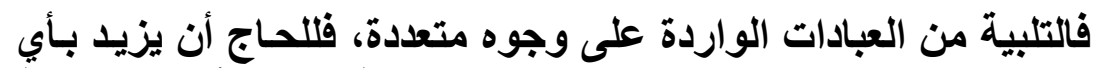

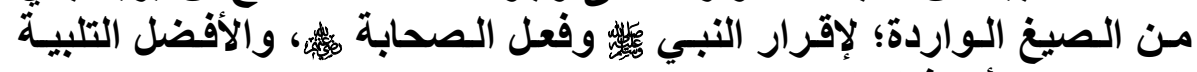

\section{المسألة الثانية

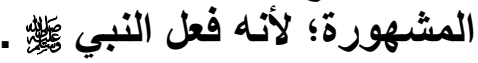

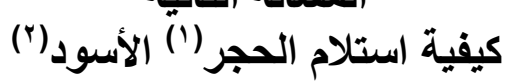

\section{في J الثلا}

الصفة الأولى: استلام الحجر الأسود وتقبيله.

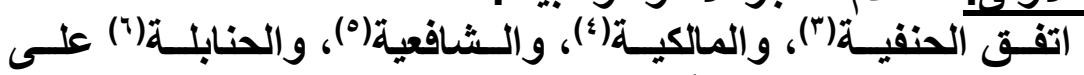

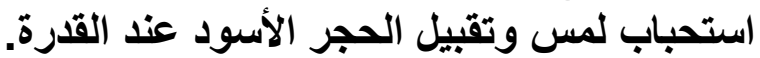

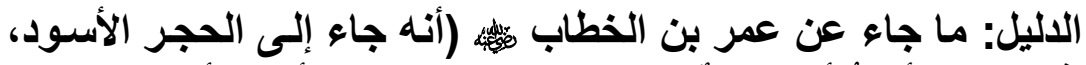

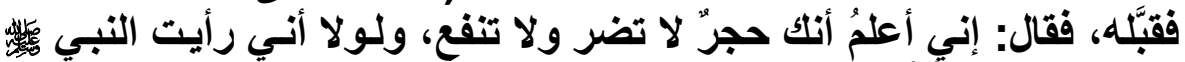

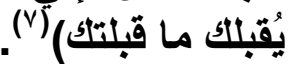

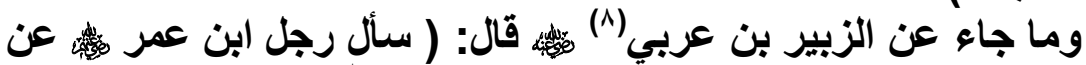

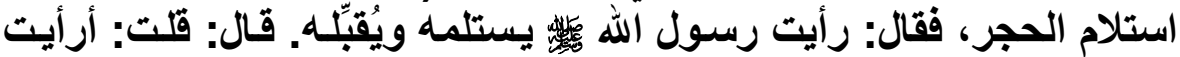

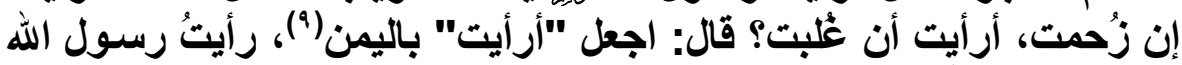

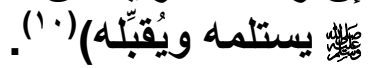

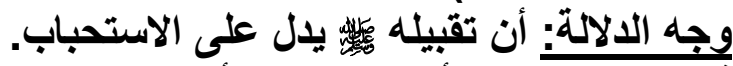

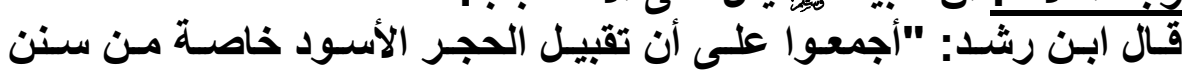

(1) استلم الحجر: لمسه، إمّا بالقبلة أو باليد. ينظر: القاموس المحيط بـاب الراء فصل

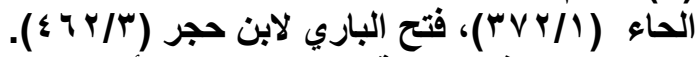

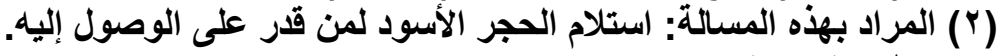

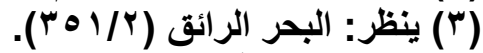

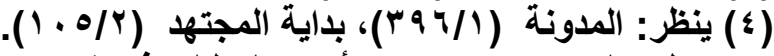

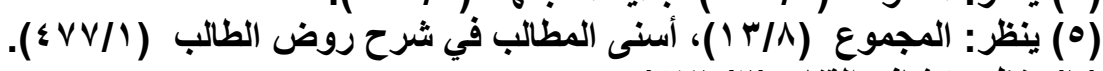

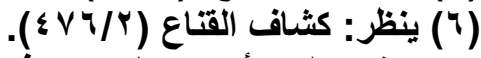

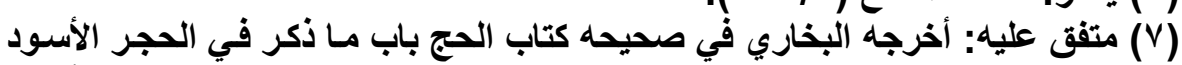

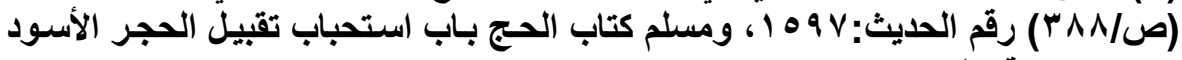

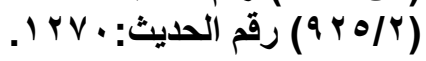

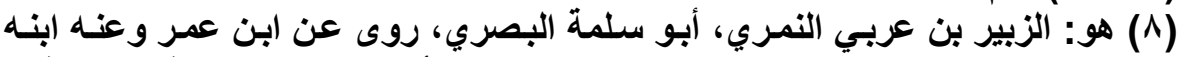

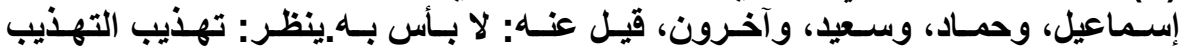

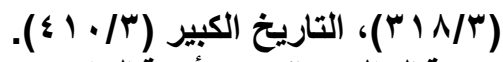

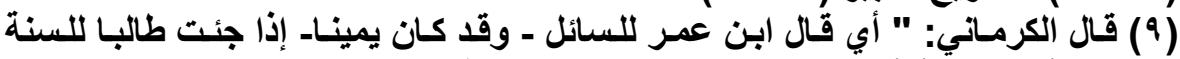

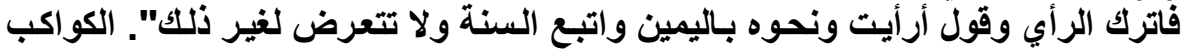

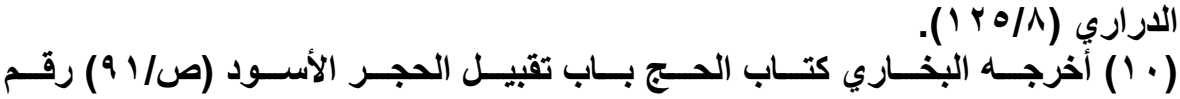

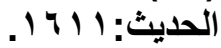


الطو اف، إن قدر" (').

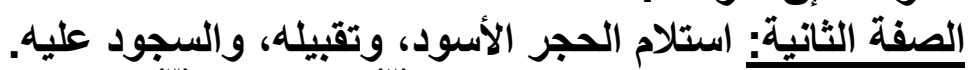

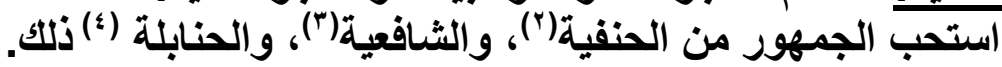

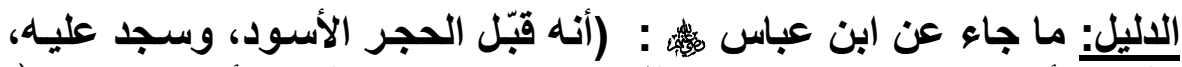

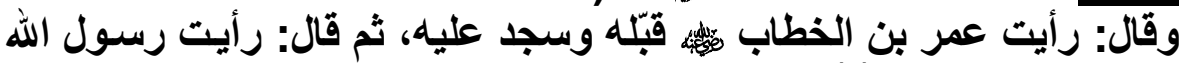

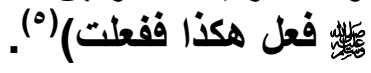

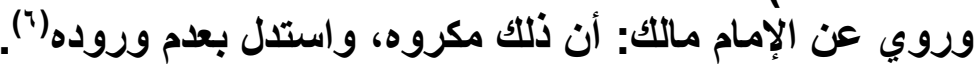

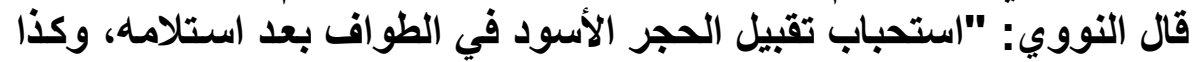

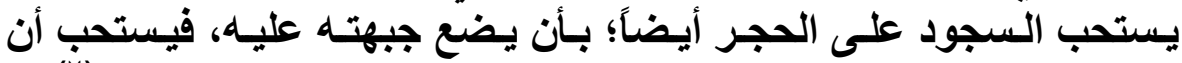

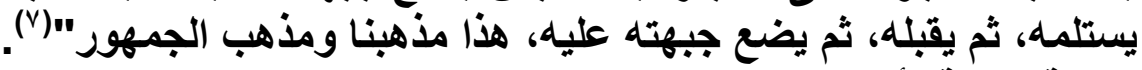

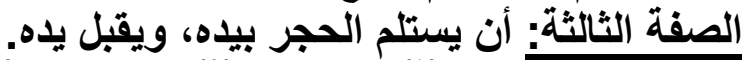

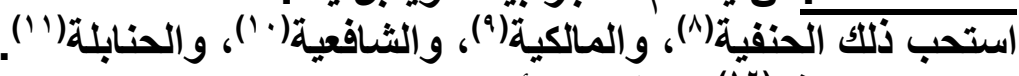

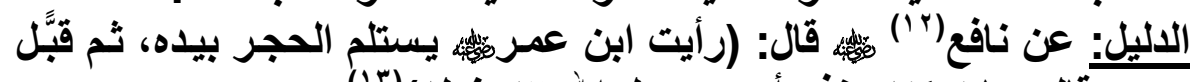

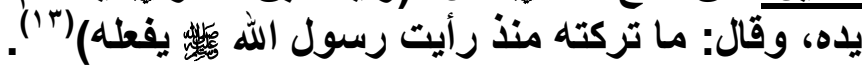

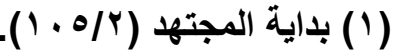

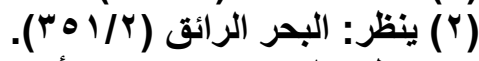

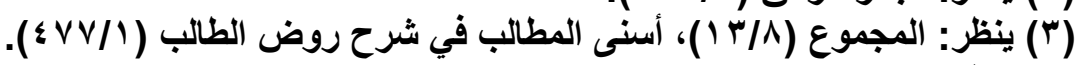

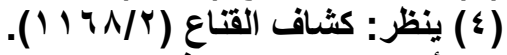

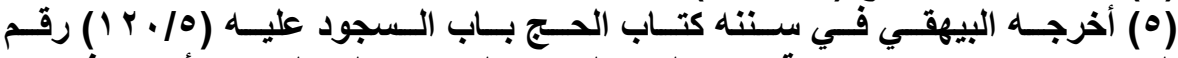

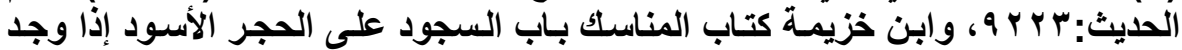

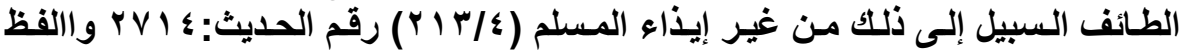

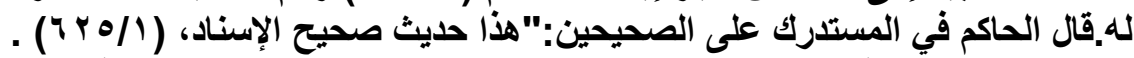

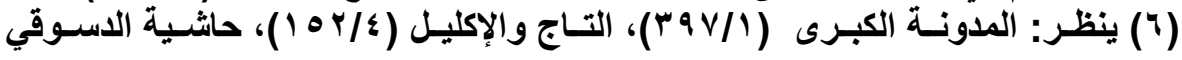
.$(\{1 / Y)$

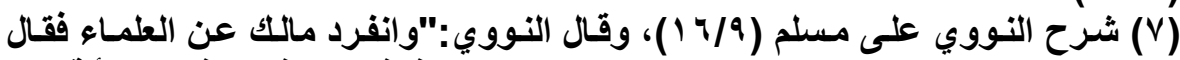
اللجود عليه بدعله واعترف القاضي عياض المـالكي بشذوذ مالكت في هذه المسألة عن

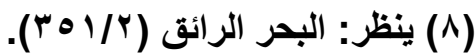

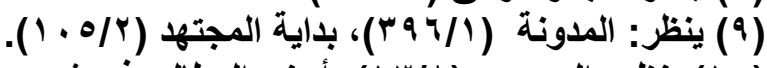

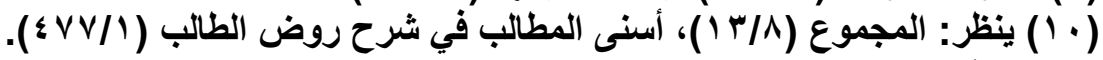

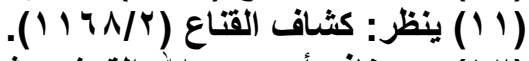

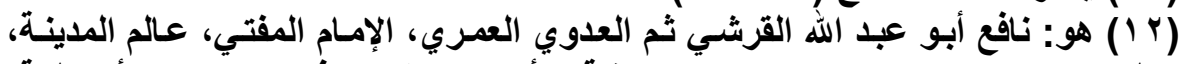

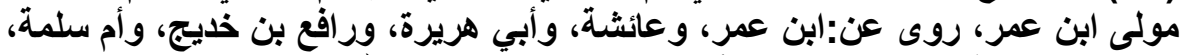

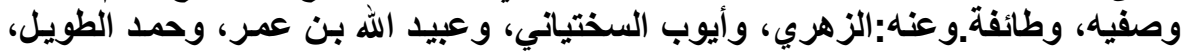

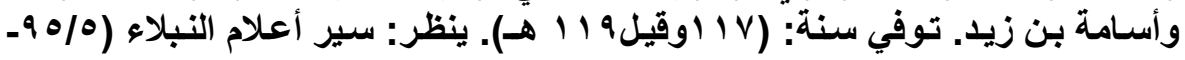

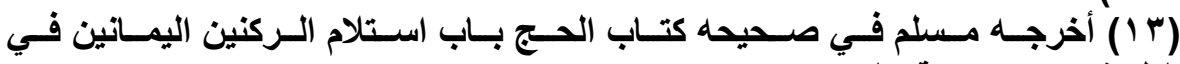

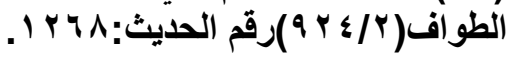




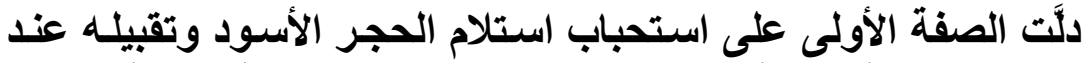

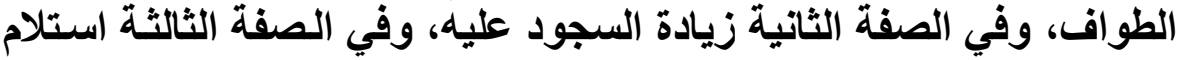
الحجر باليد، وتقبيل اليد.

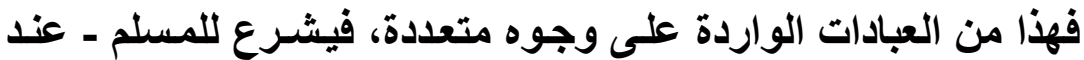

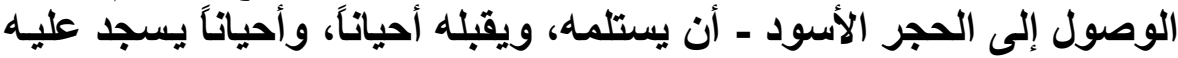

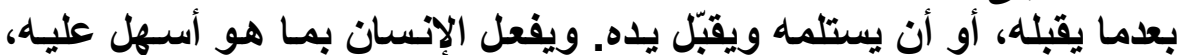

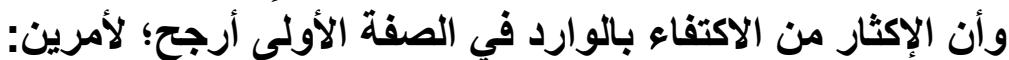

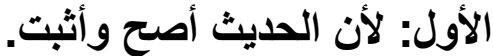
الثاني: لأن العمل بالصفة الأولى موضع التفاق من أهل العلم. والله أعلم لمسألة لثالثة

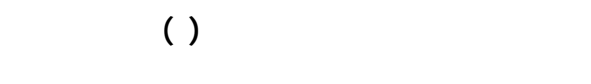

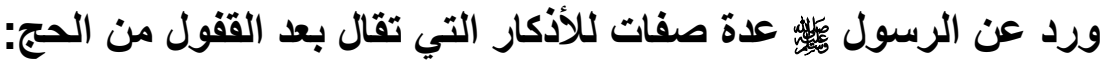

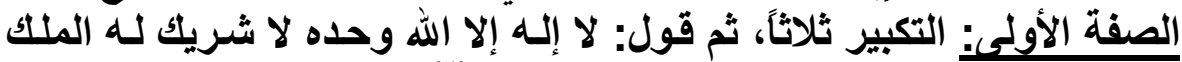

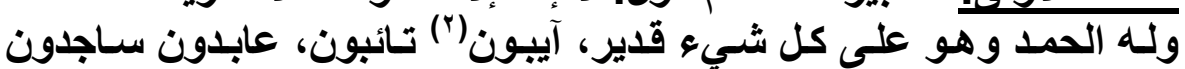

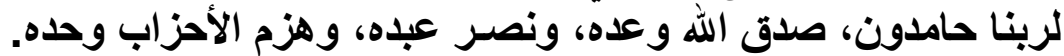

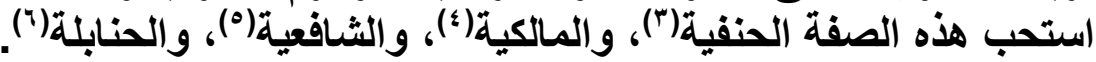

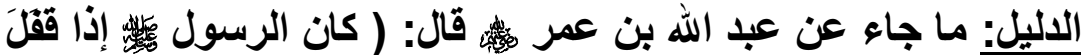

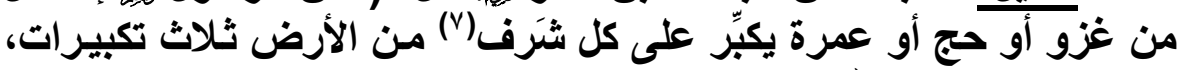

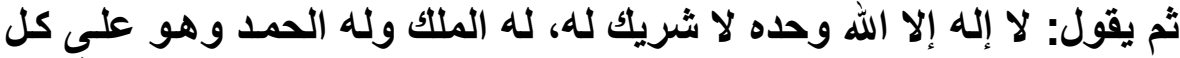
شيء قير.آيبون، تائبون، عابدون، ساجدون ، لربنا حامدون.صدق الله

(1) القفول: أي الرجوع من السفر. ينظر مقاييس اللغة بـاب القاف والفـاء مـادة :قفي ) التفي

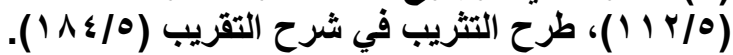

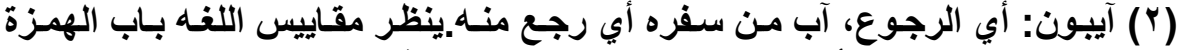

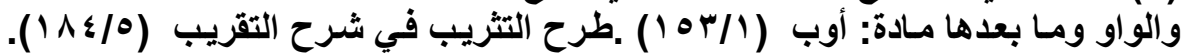

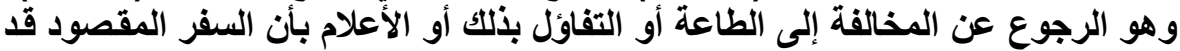

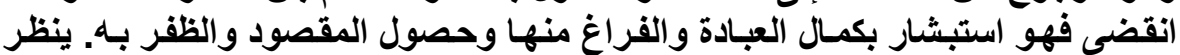

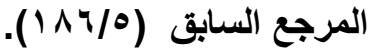

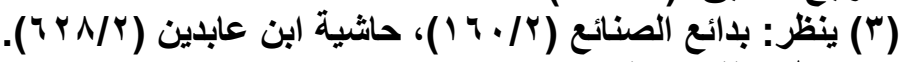

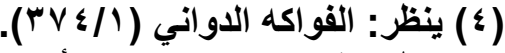

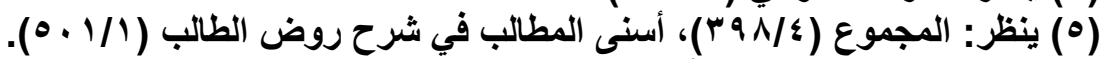

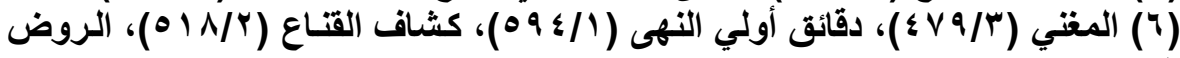

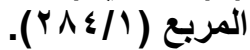
(V) شرف: أي العلو والارتفاع، ينظر مقاييس اللغة باب الثين والراء (اء وما يثلثهما مـادة:

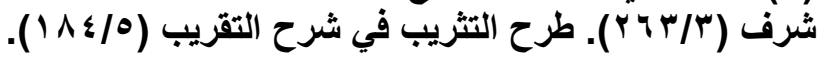


وعده، ونصر عبده، وهزم الأحزاب وحده)(').

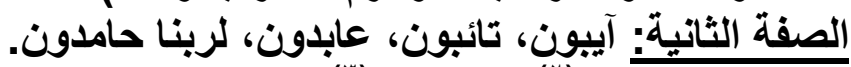

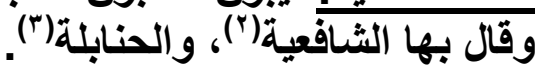

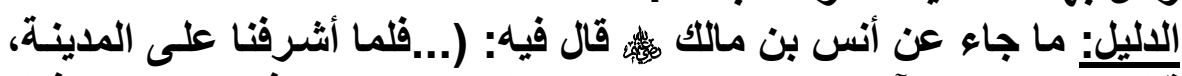

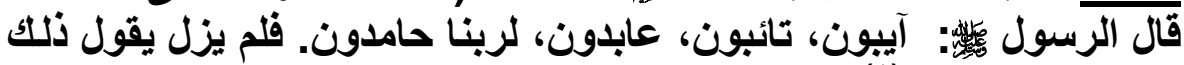

حتى دخل المدينة) (أ) الرنول

وهذا من التنوع، ويترجح الأكر الأول؛ لكونه جامعاً.

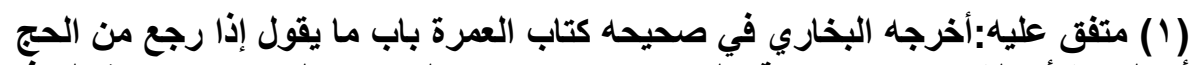

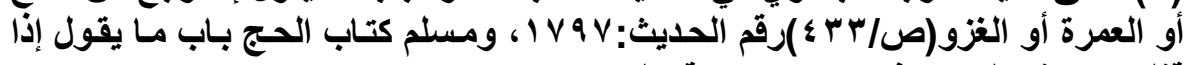

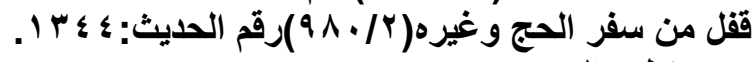

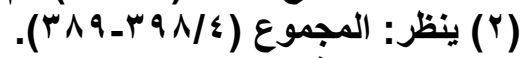

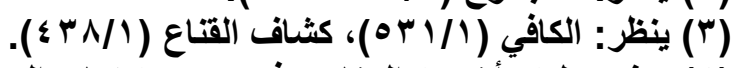

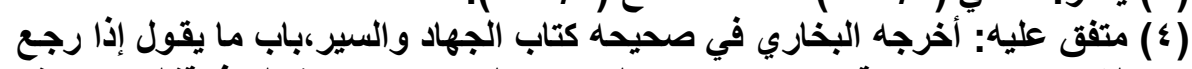

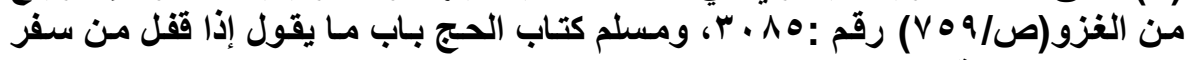




\section{الخــــاتمة}

وختامًاً أحمد اللهَ - سبحانه وتعالى ـ كما حمدته في البده؛ فهو وحده الذي

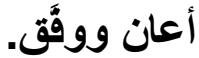
نتائج البحث : نئ

ومن خلال العرض البح الأي حوى هذا البحث يتبين أن أبرز النتائج التي توصلت لها، هي ما يلي:

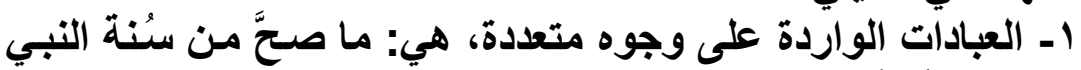

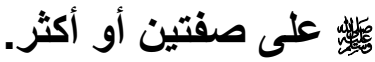

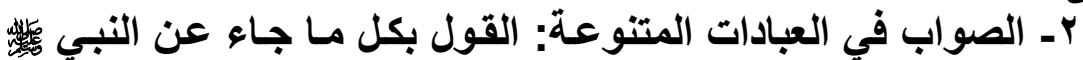

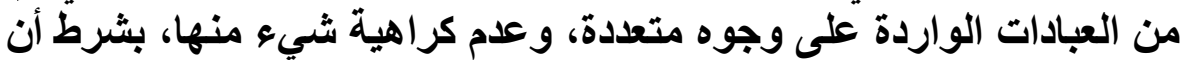

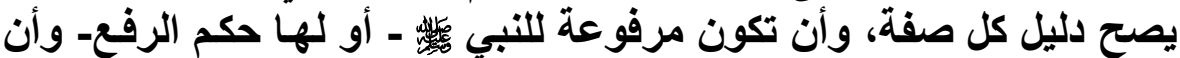

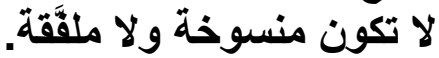

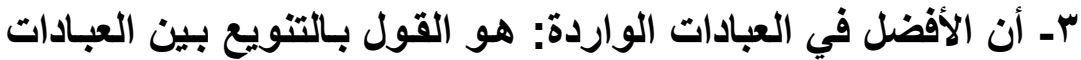

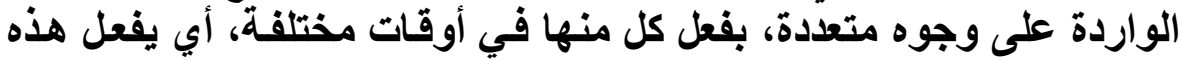
الصفة تارة وتلك تارة أخرى أعرد.

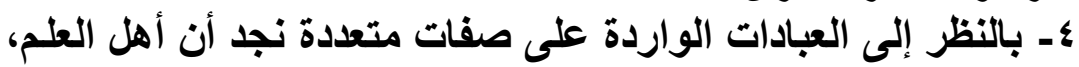

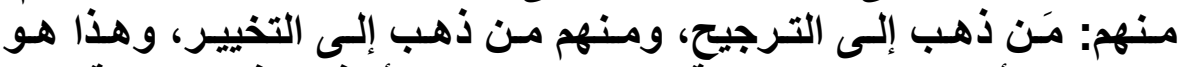

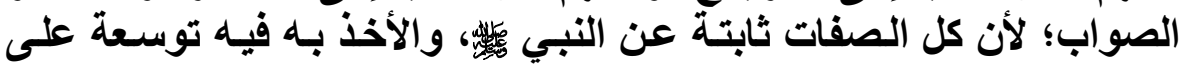

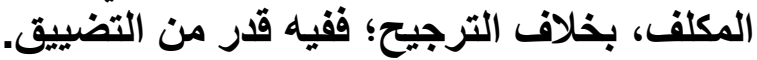

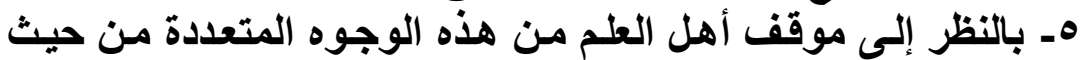

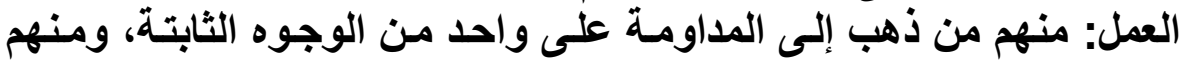

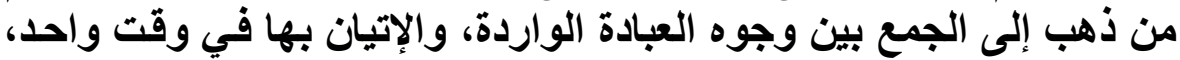

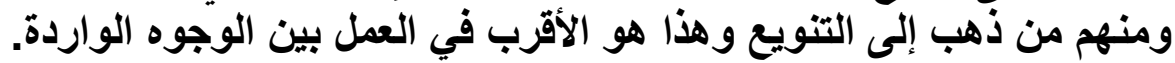

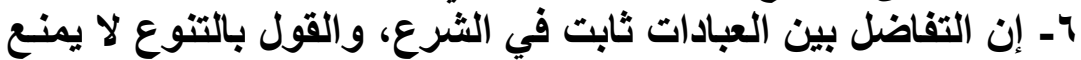
من تفضيل بعض الصفات لسبب أو أكثر من أسباب التفضين التضيل، ولكن دون هجر لبقية الصفات.

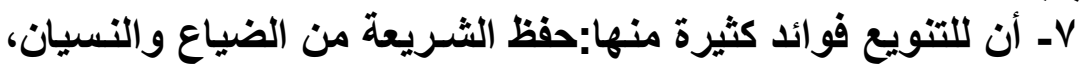

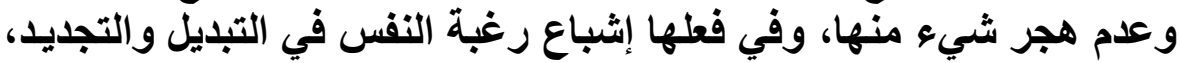

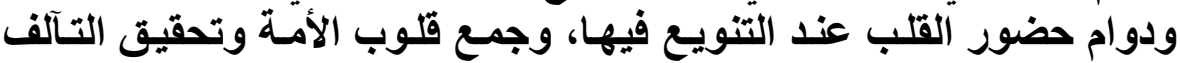

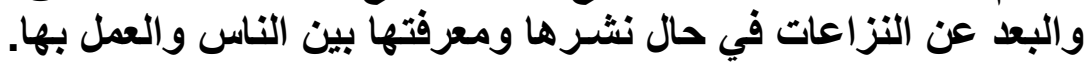

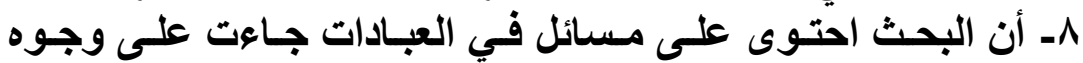

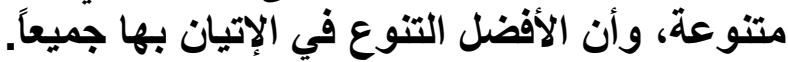

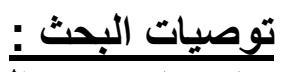

أوصي بإحصاء جميع العبادات الواردة على وجوه متعددة، في بحث مستقل.

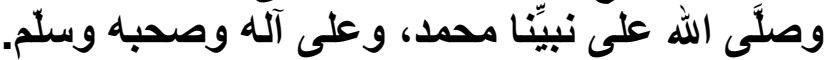




\section{المصادروالمراجع}

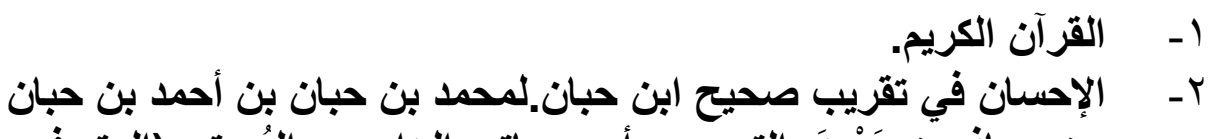

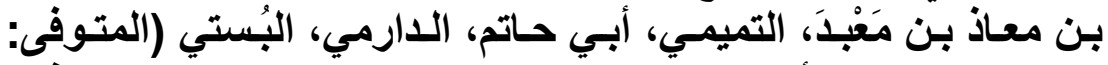

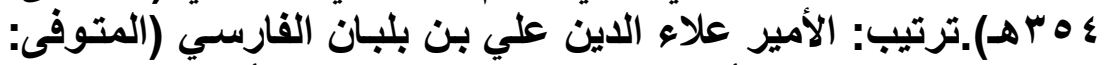

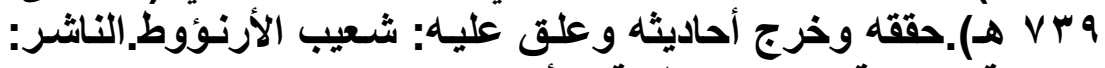

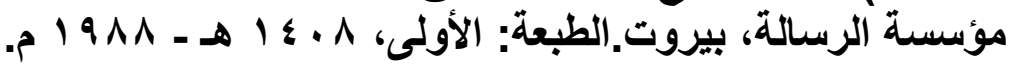

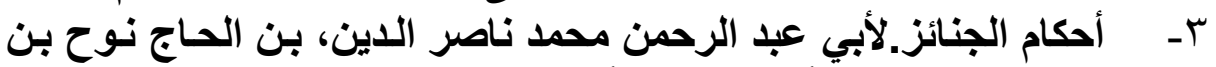

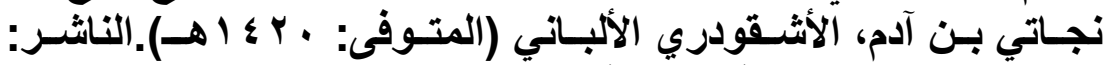

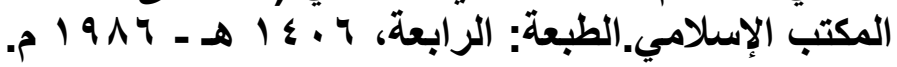

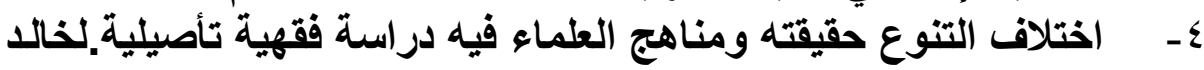

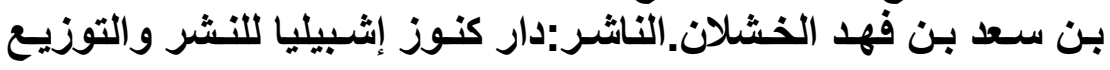
. $1 \leqslant Y$

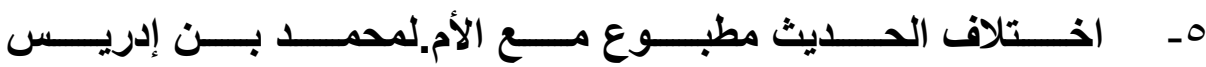

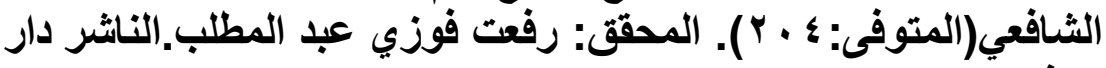

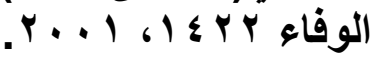

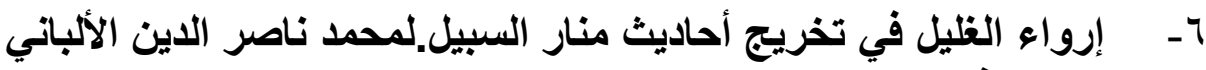

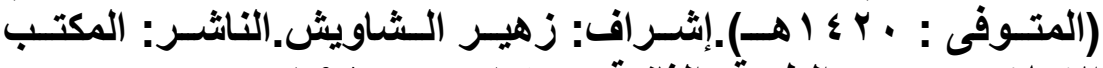

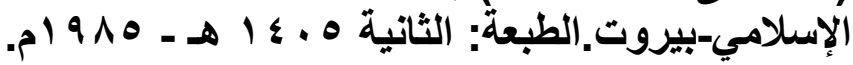

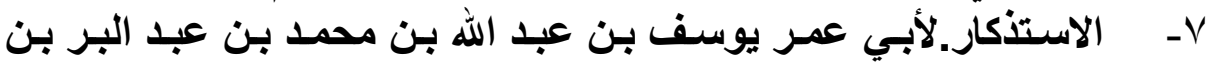

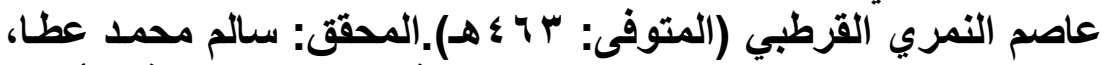

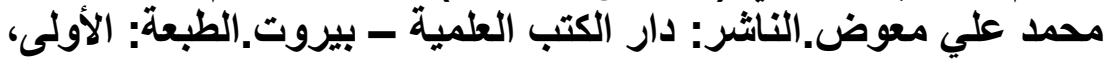

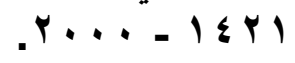

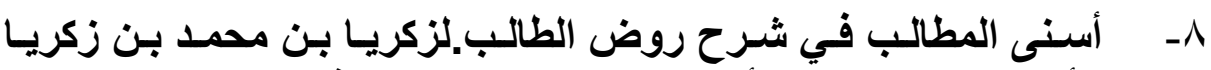

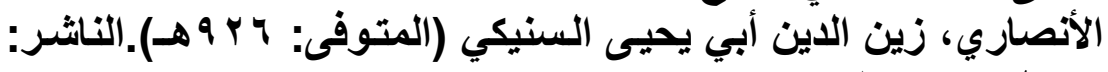

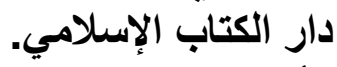

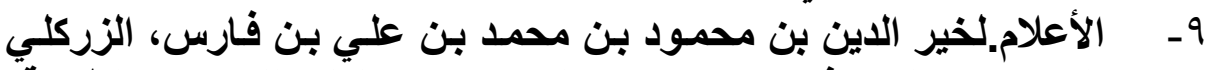

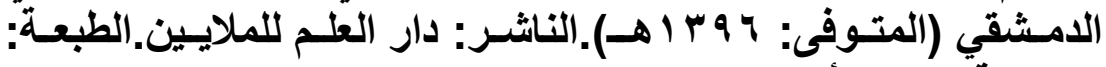

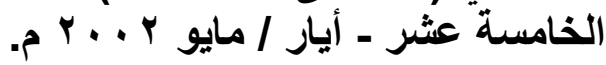

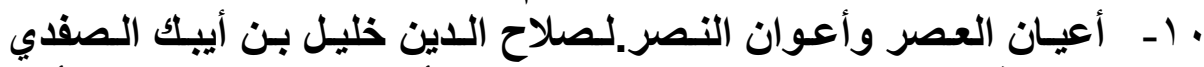

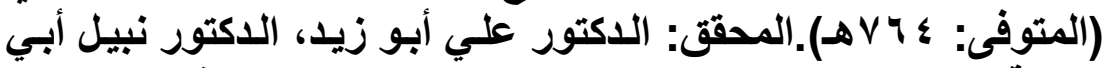

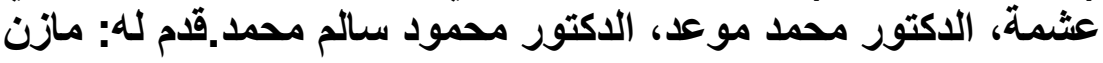

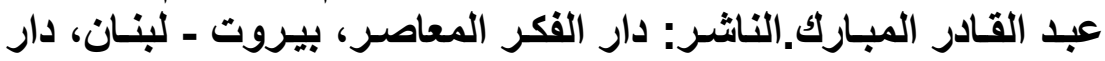

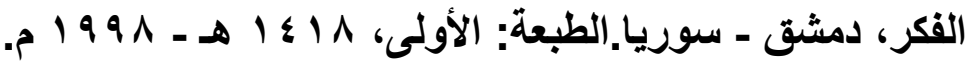

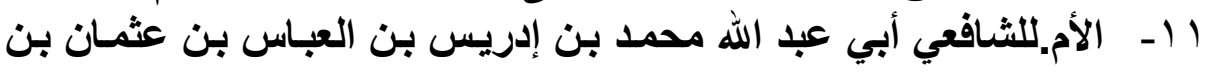


شافع بن عبد المطلب بن عبد مناف المطلبي القرشي المكي (المتوفى:

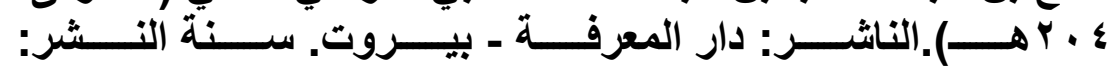
(9.9.

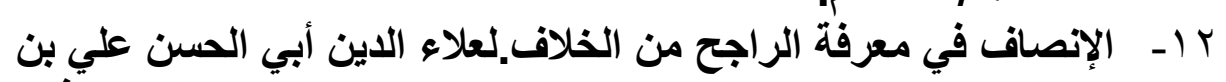

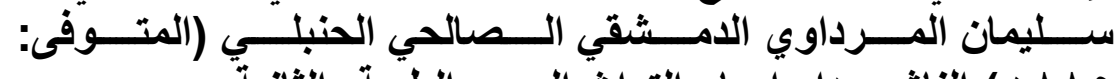

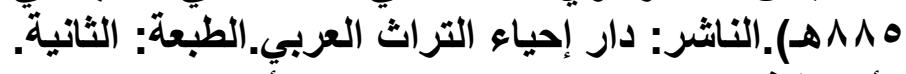

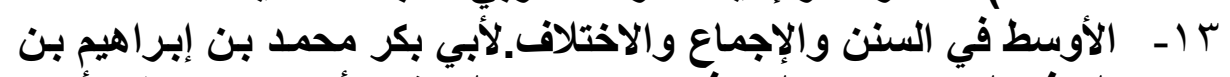

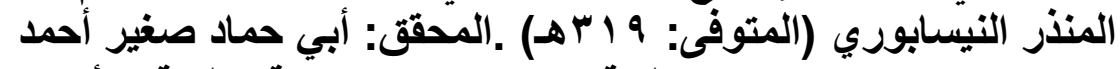

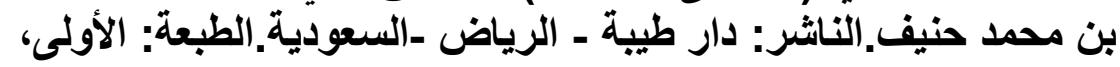

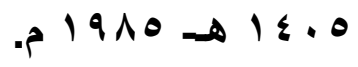

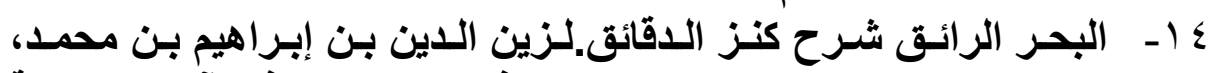

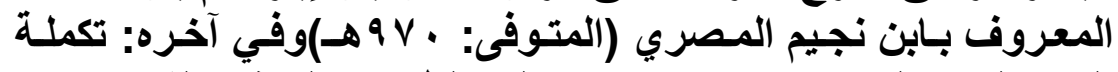

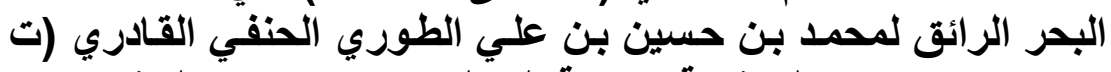

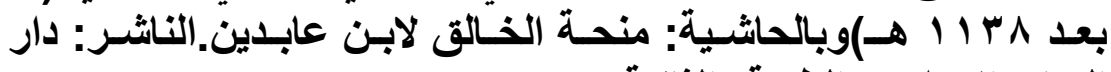

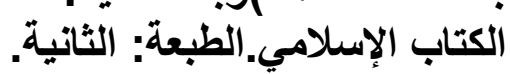

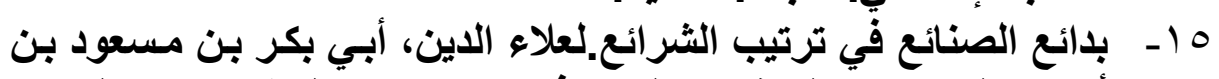

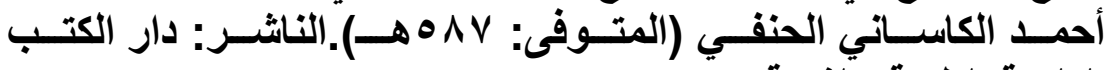

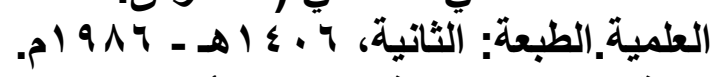

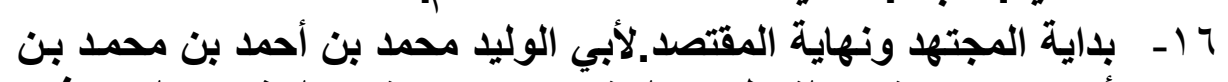

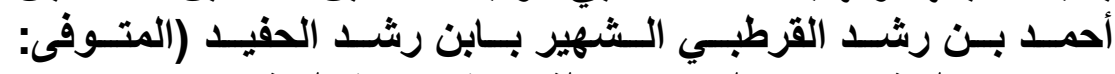

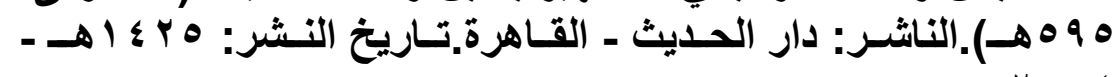

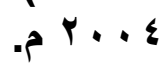

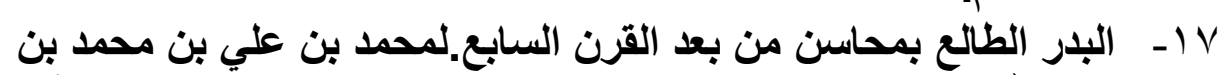

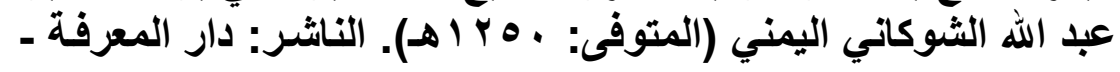

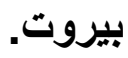

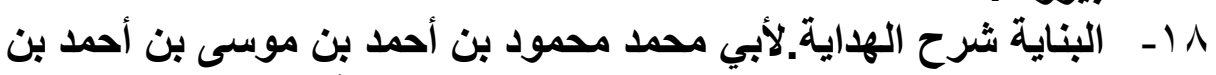

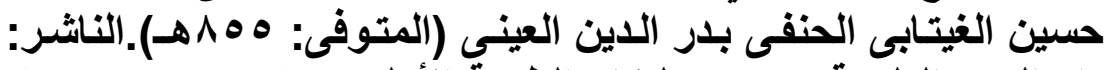

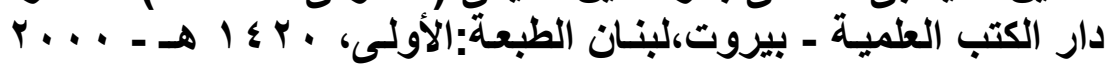

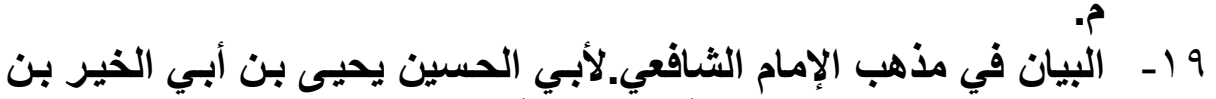

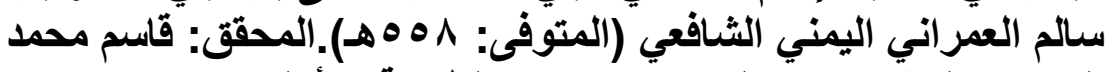

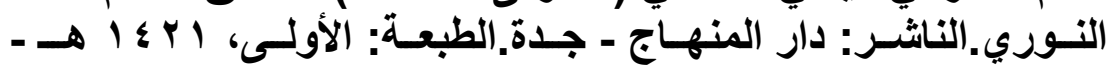

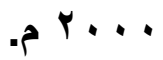

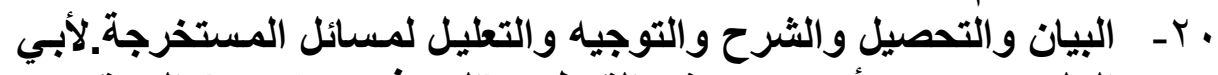

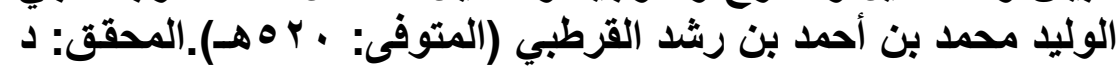

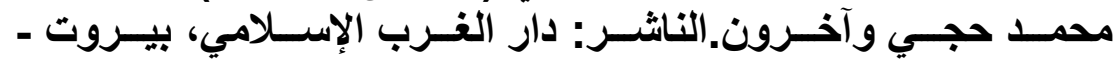




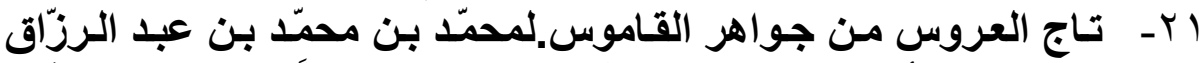

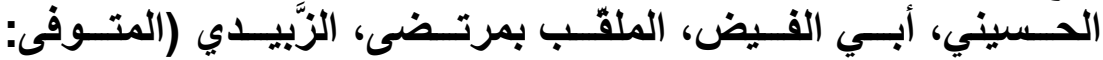

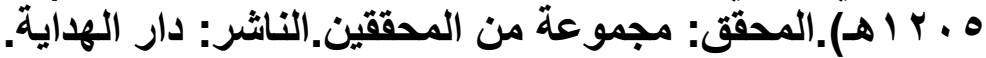

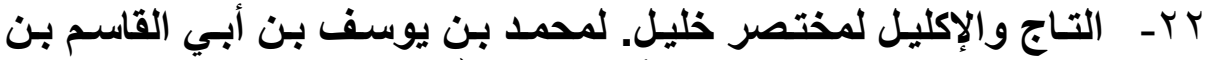

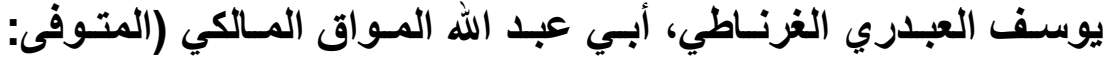

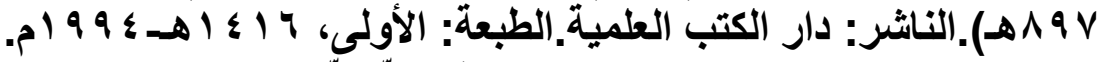

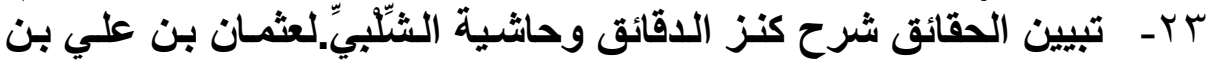

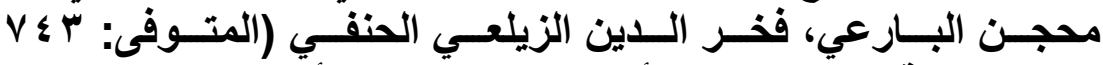

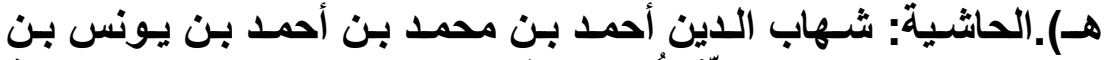

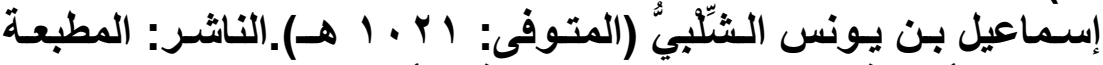

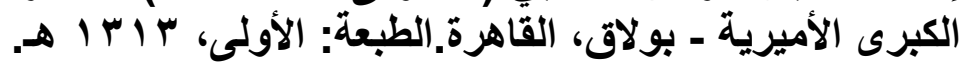

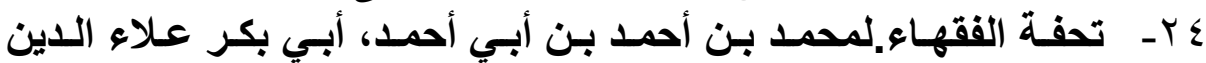

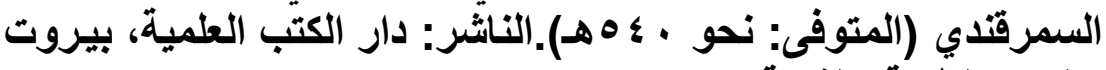

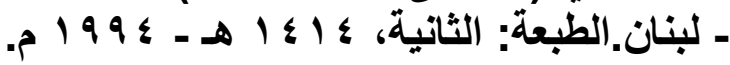

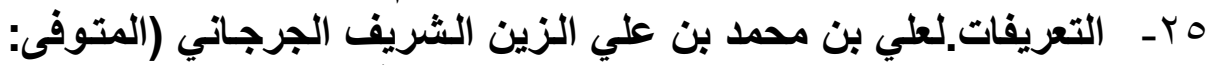

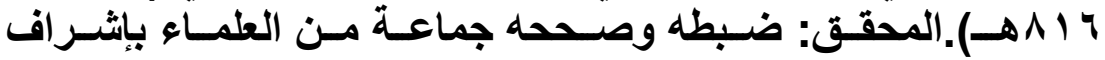

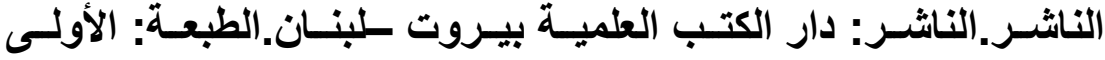

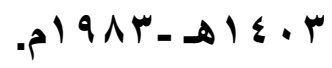

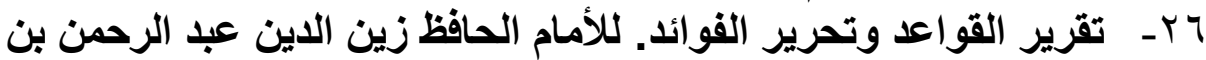

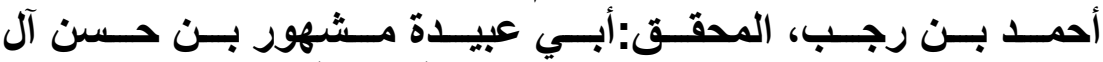

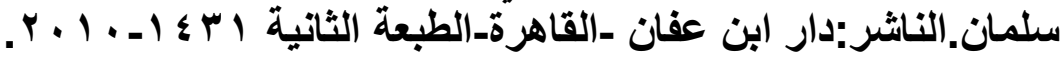

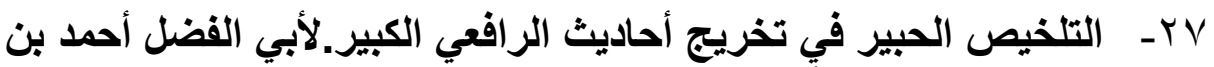

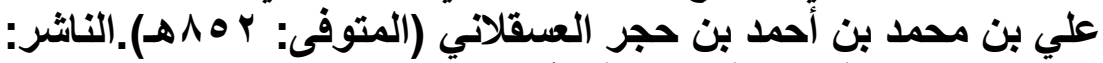

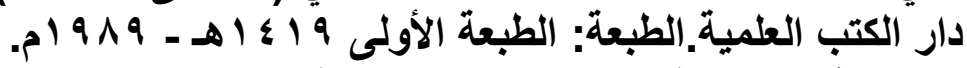

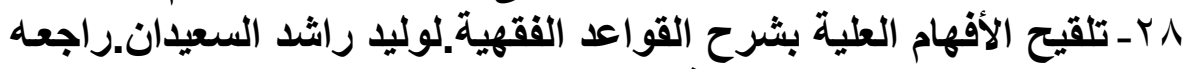

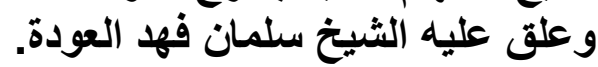

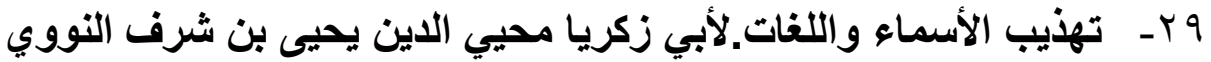

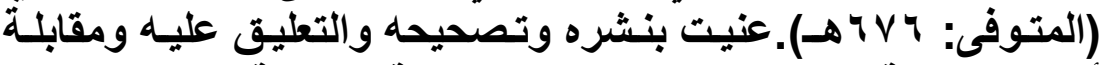

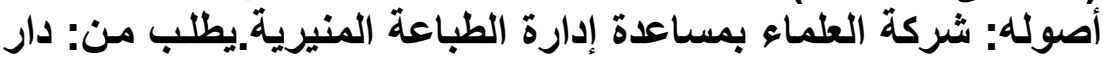

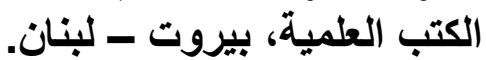

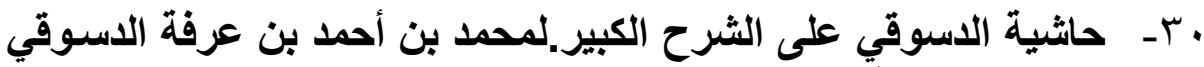

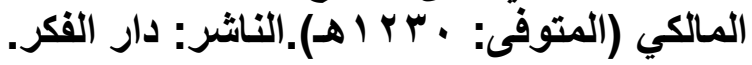

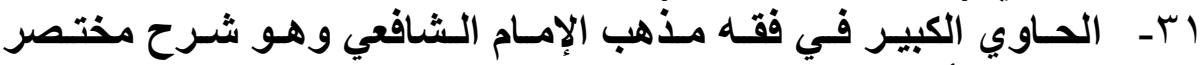

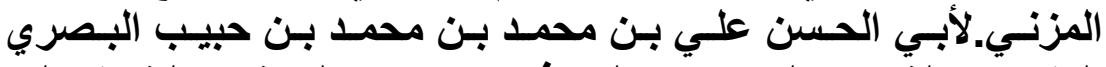

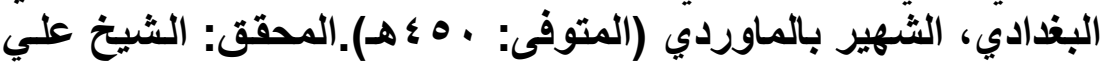


محمد معوض - الشيخ عـادل أحمد عبد الموجـود.الناشـر: دار الكتب العلمية، بيروت ــ لبنان.

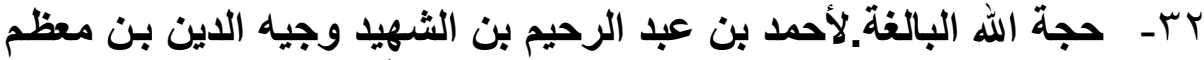

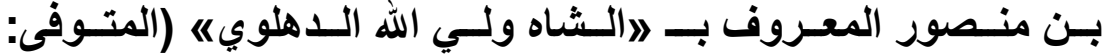

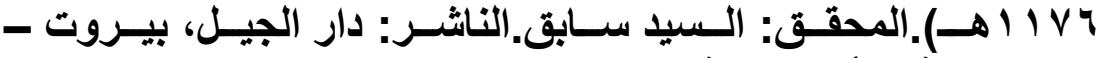

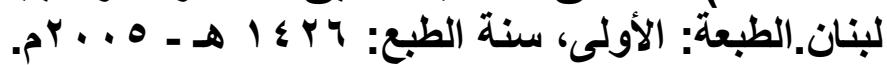

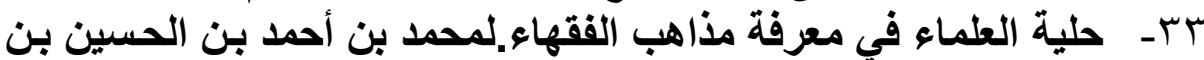

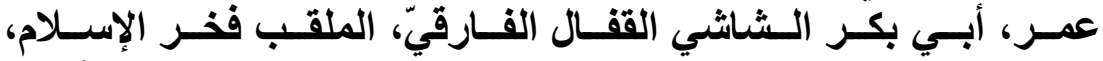

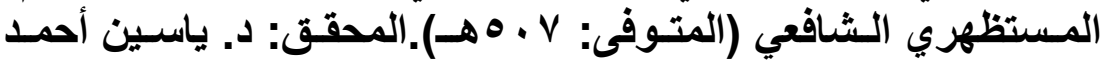

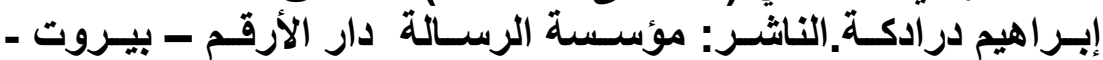

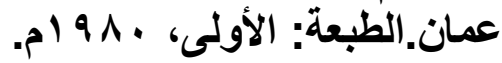

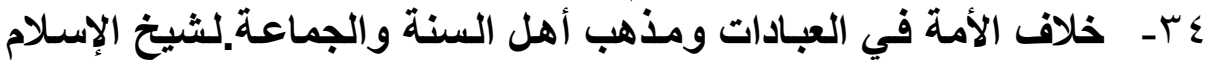

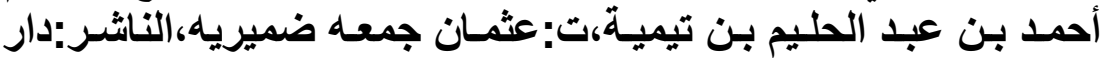

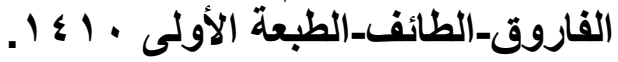

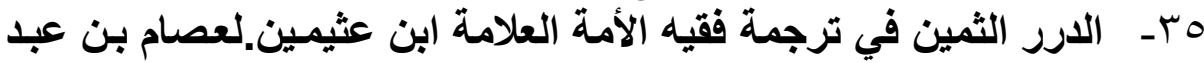

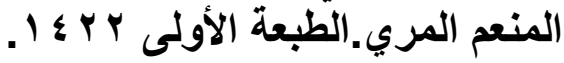

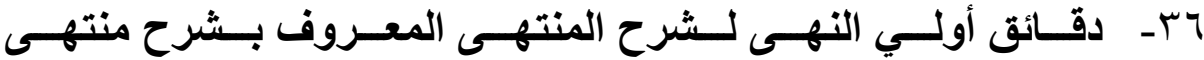

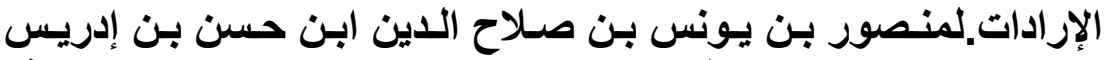

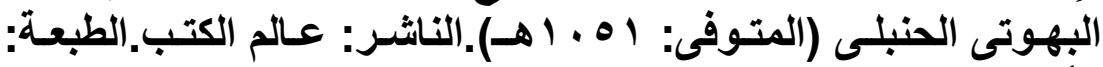

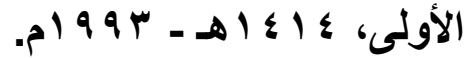
rV

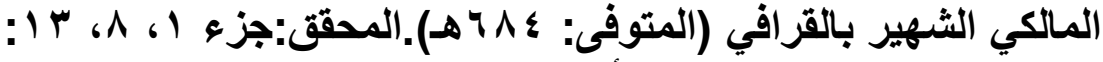

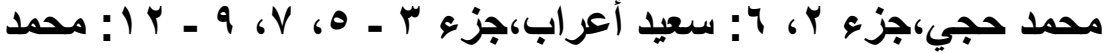

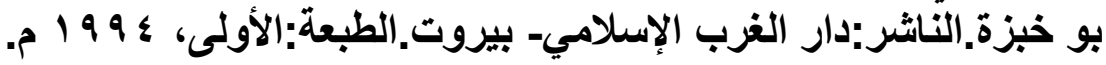

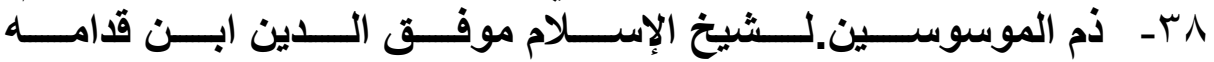

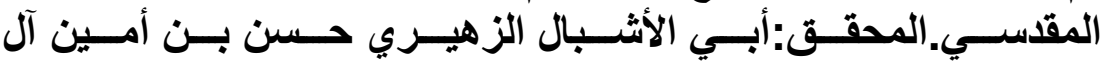

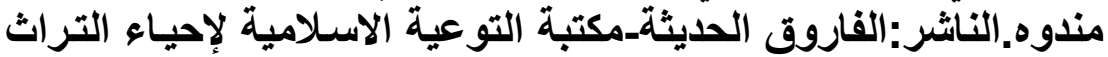

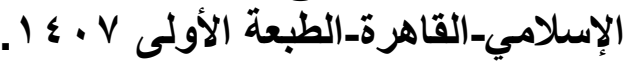

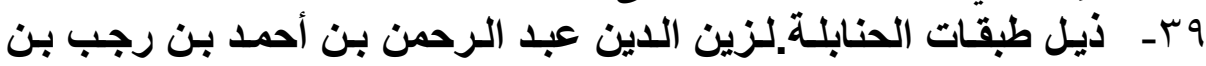

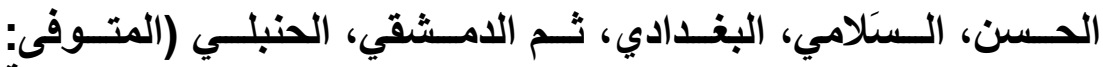

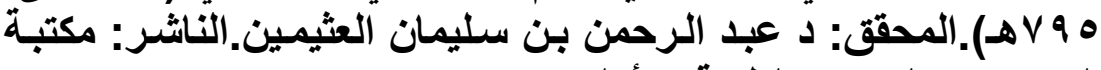

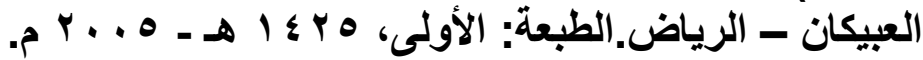

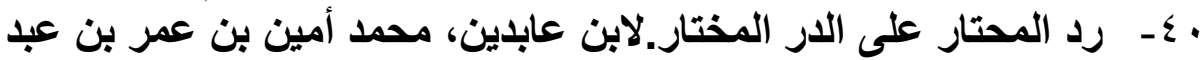

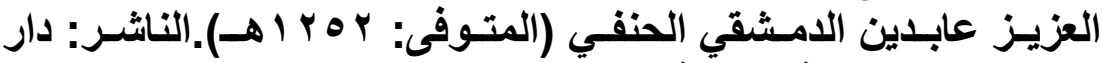

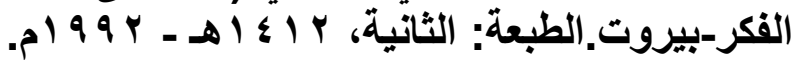

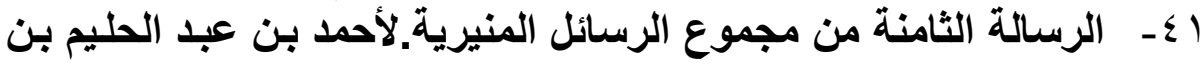




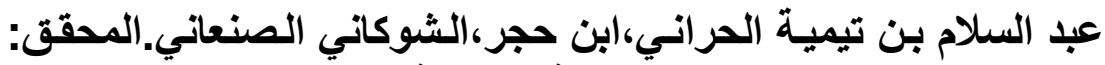

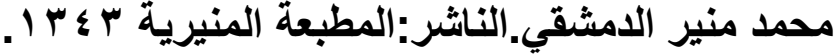

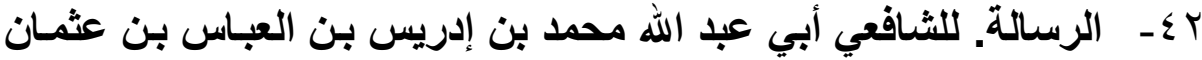

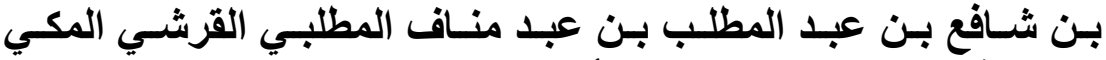

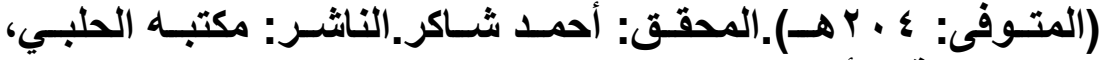

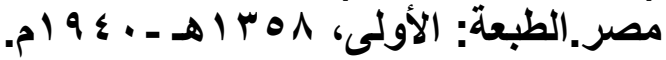

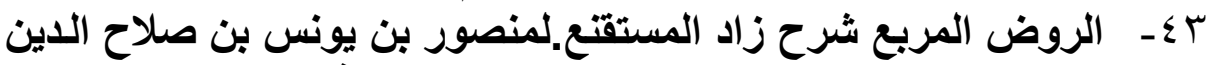

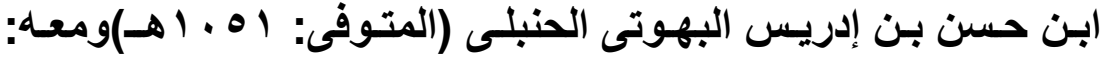

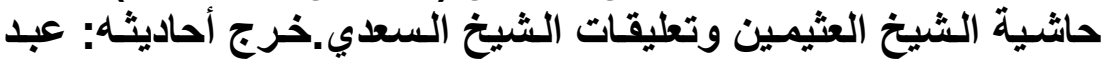

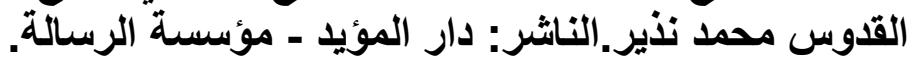

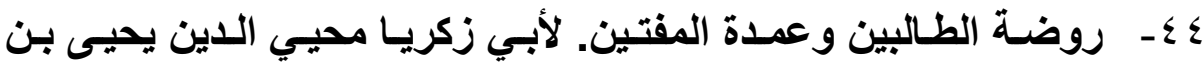

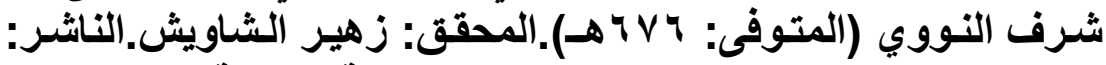

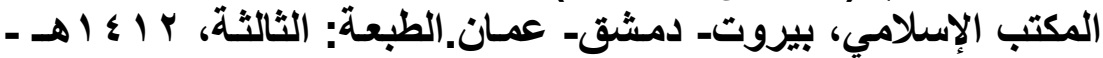

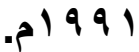

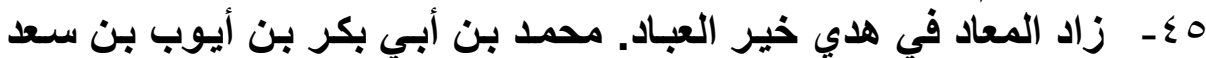

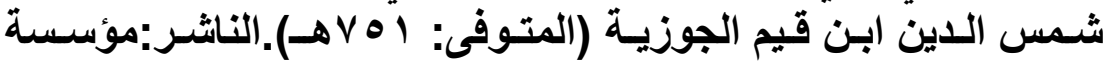

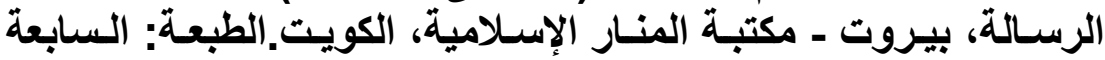

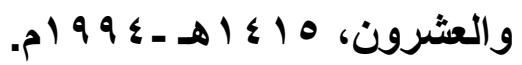

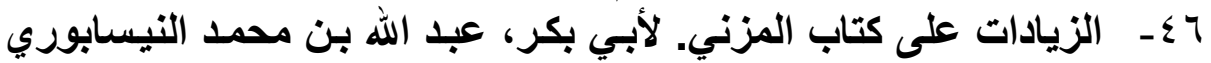

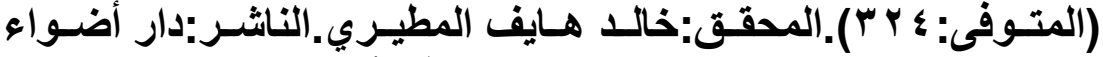

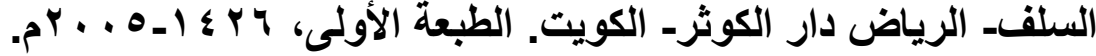

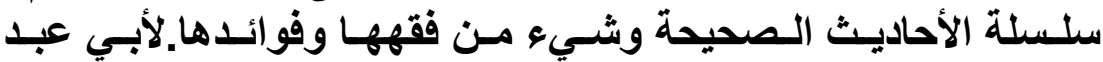

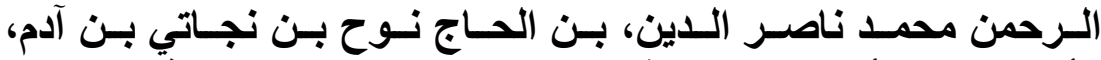

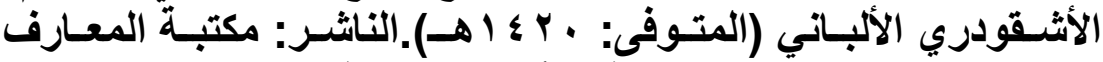

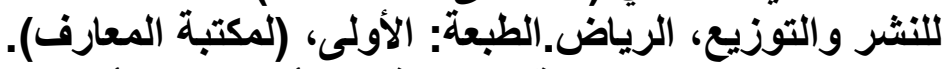

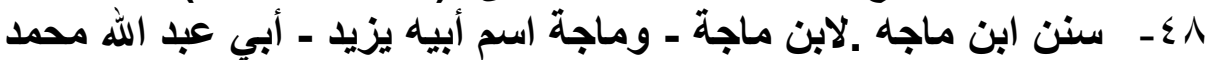

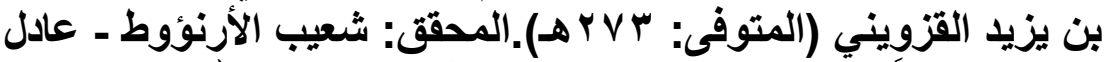

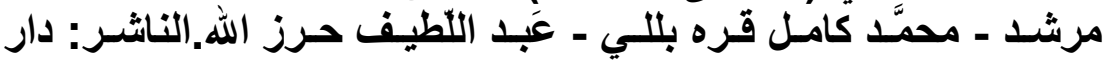

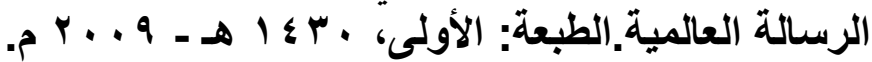

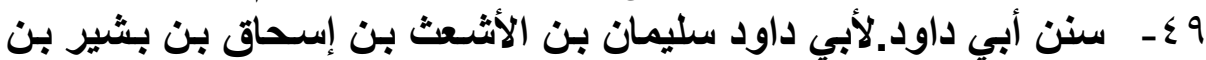

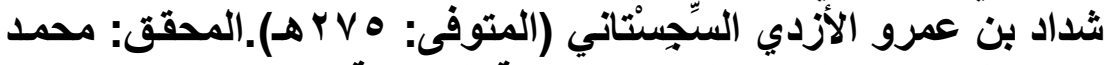

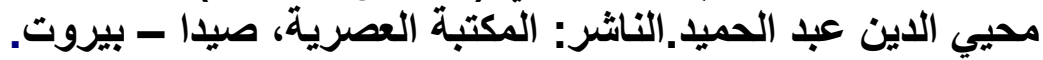

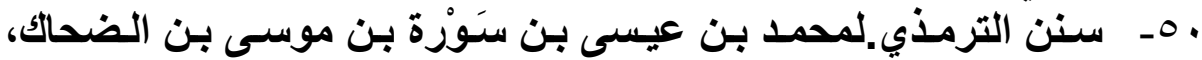

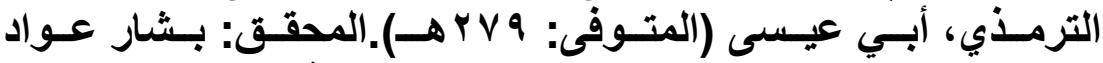

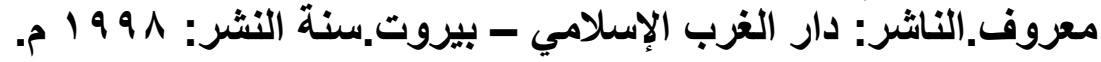

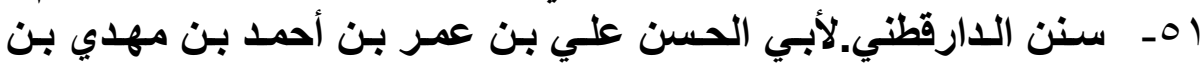




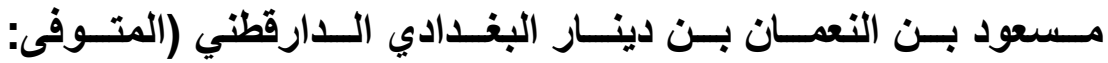

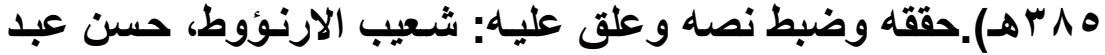

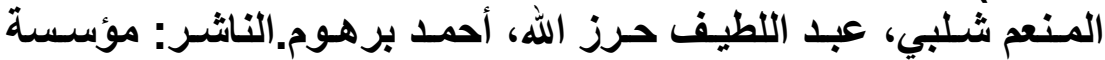

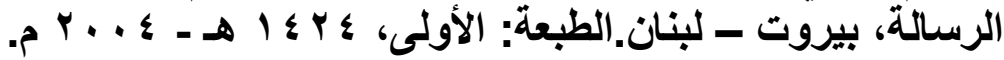

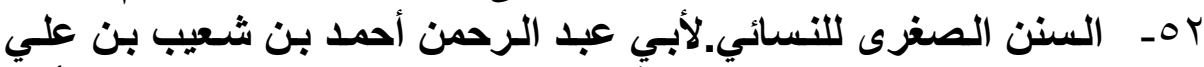

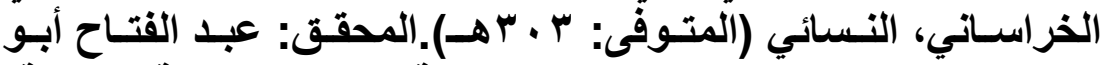

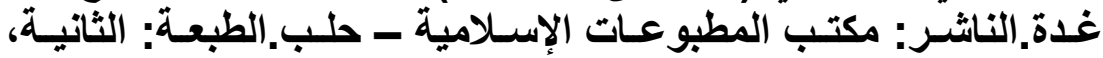
$.19 \wedge 7-1 \leq .7$

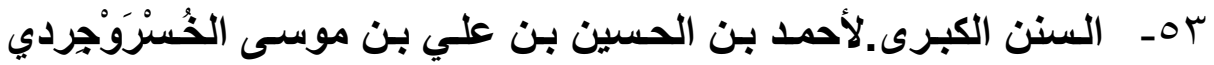

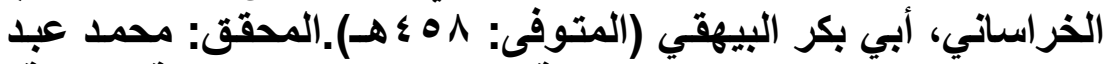

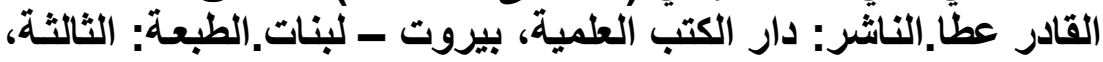

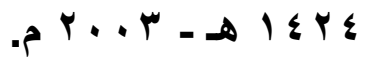

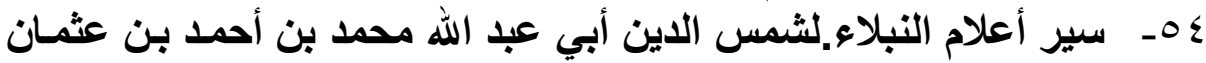

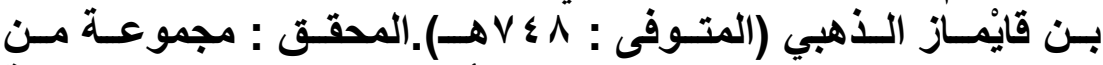

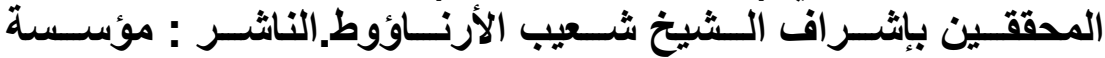

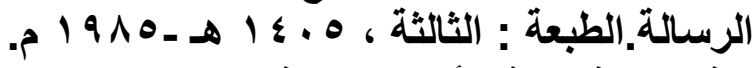

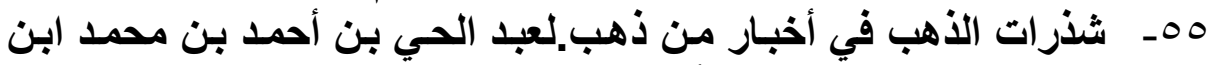

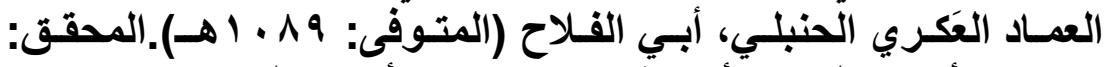

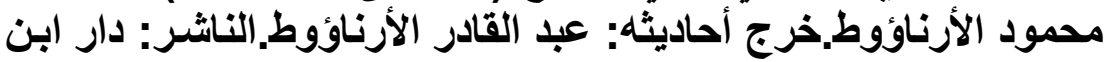

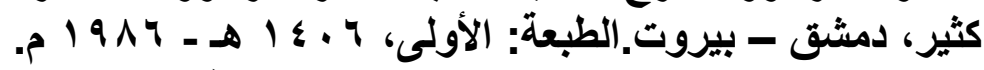

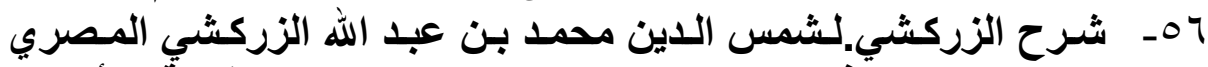

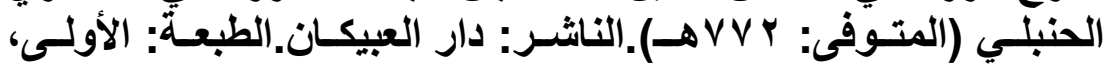

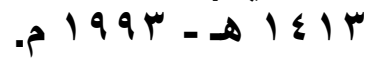

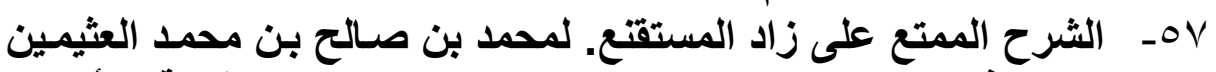

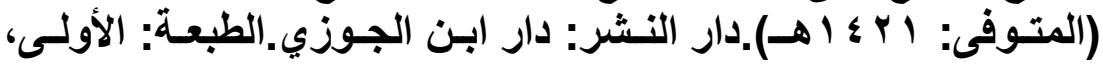
هـ $1 \leqslant Y \wedge-1 \leqslant r Y$

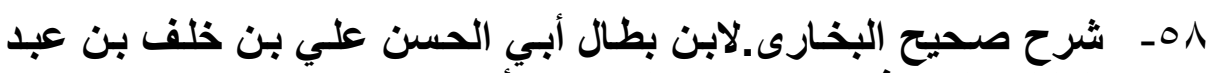

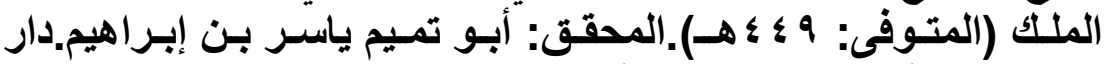

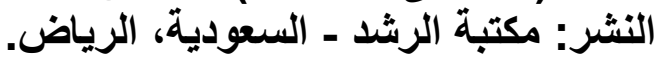

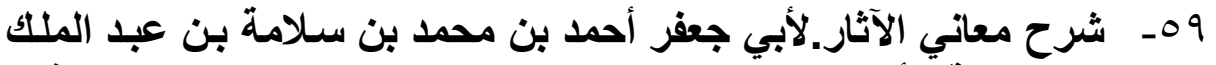

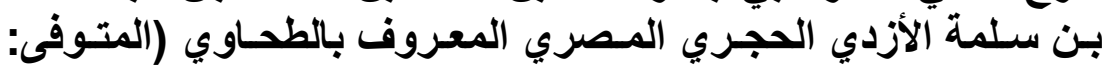

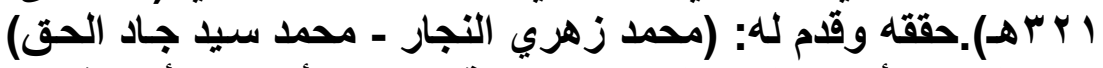

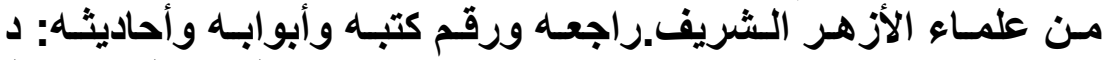

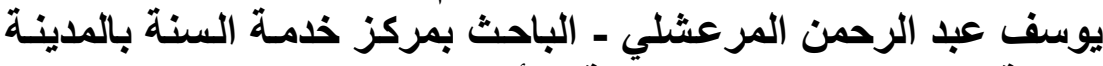

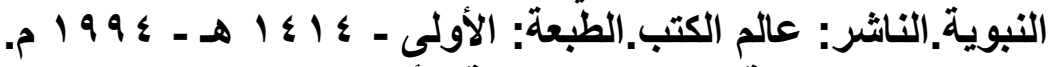

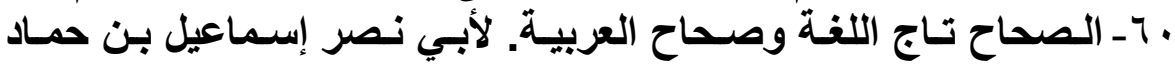




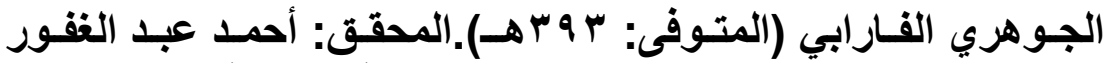

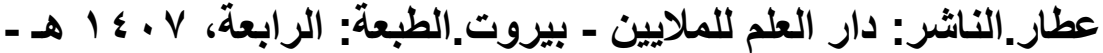

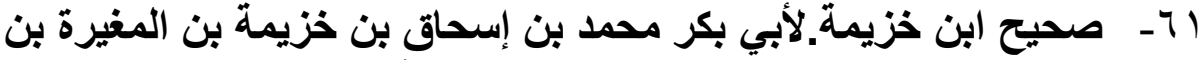

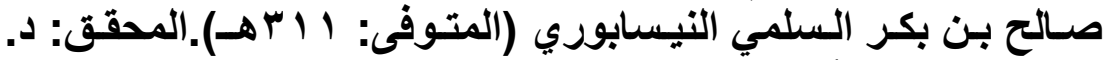

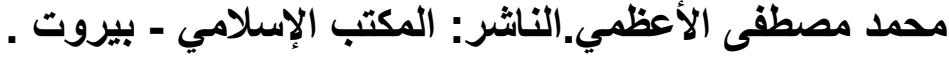

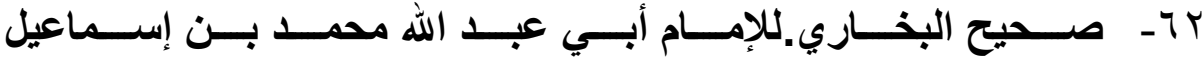

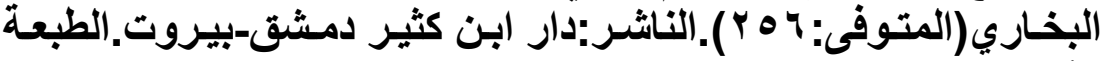

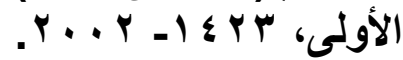

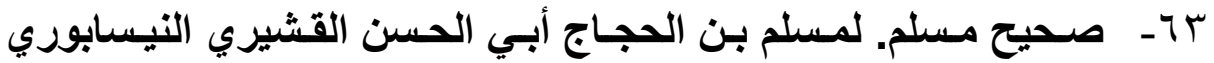

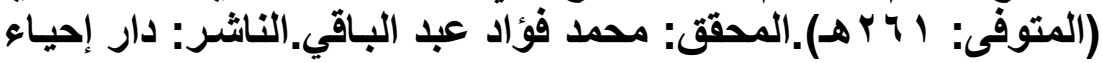

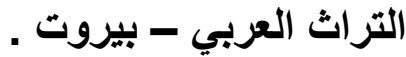

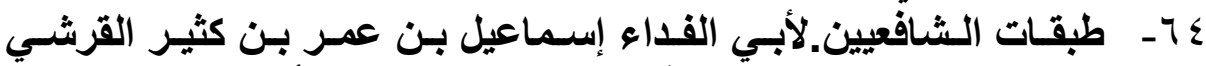

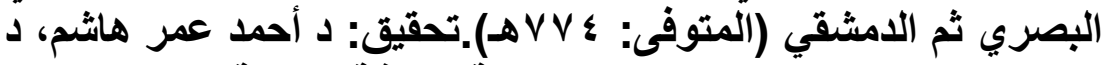

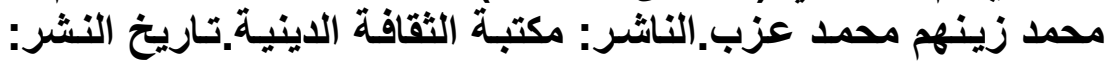

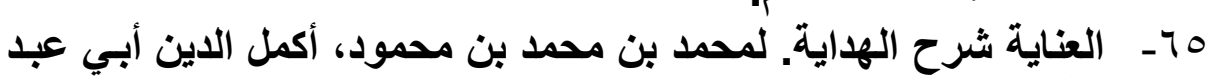

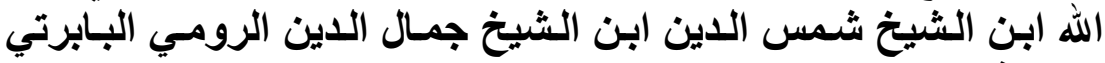
(المتوفى:

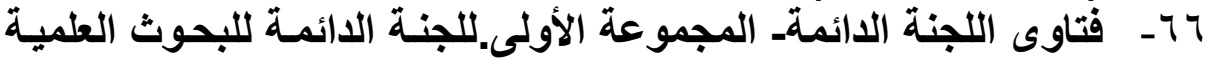

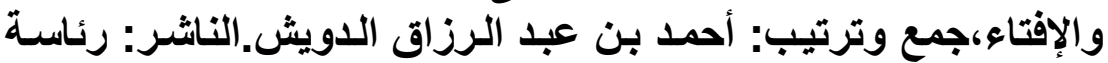

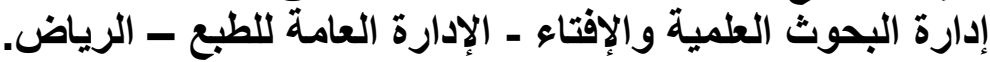

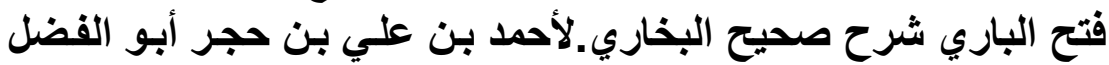

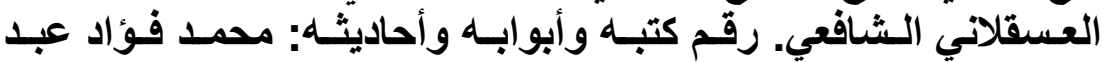

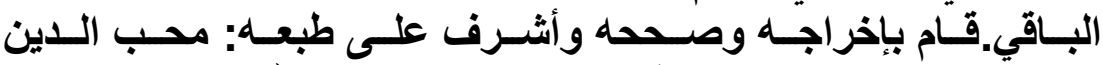

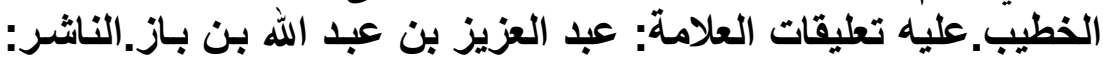

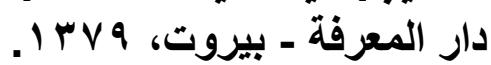

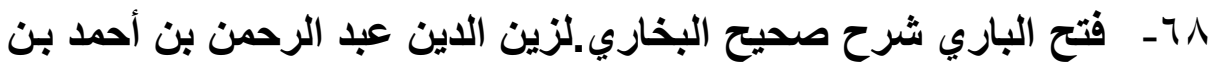

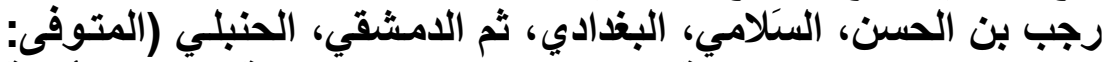

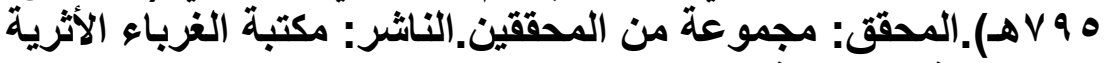

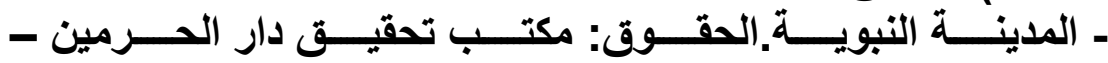

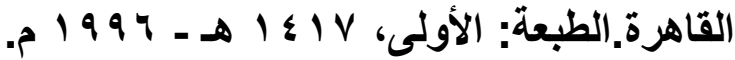

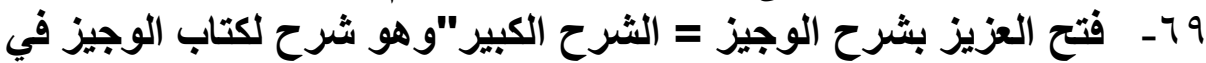

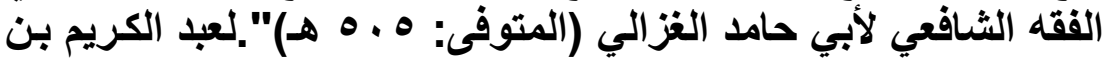

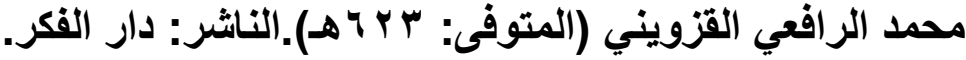

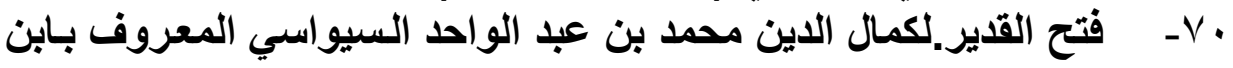


الهمام (المتوفى: 1 آ^هـ).الناشر: دار الفكر.

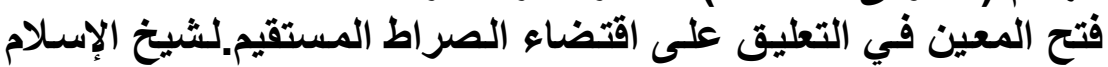

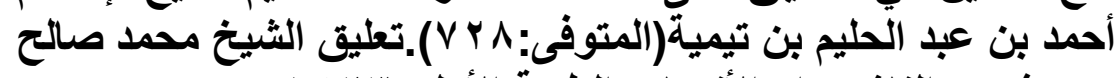

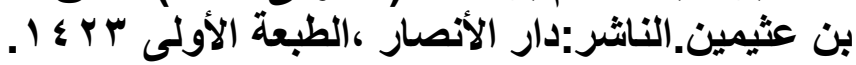

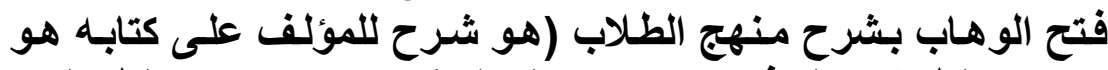

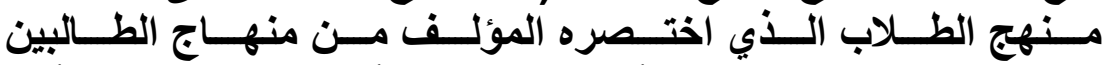

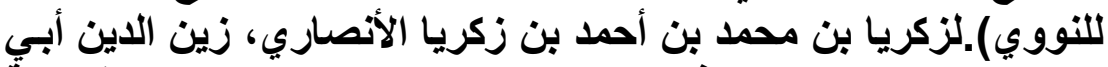

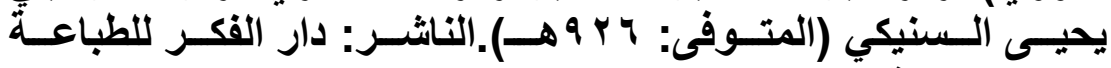

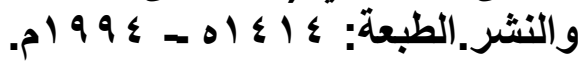

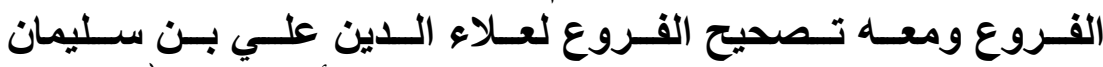

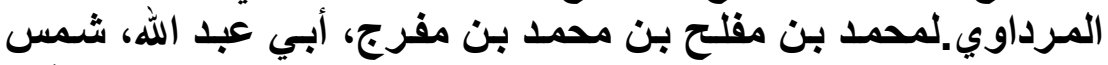

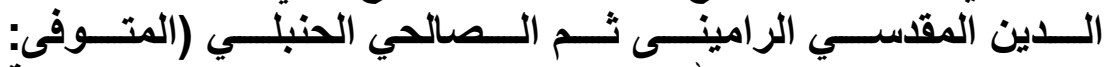

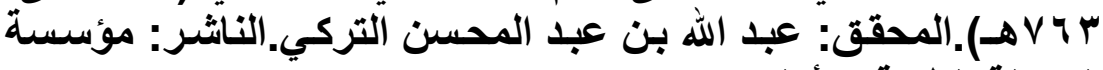

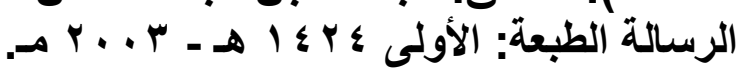

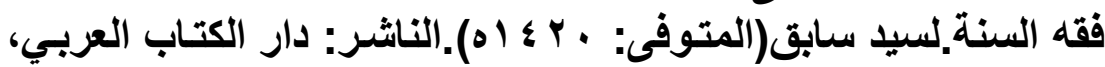
$-V \varepsilon$

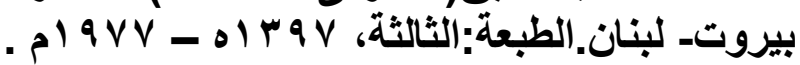

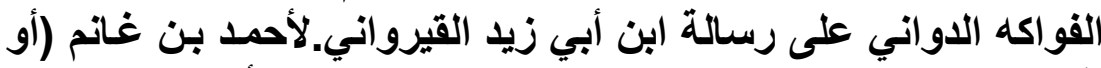
$-v 0$

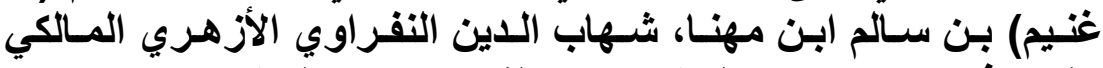

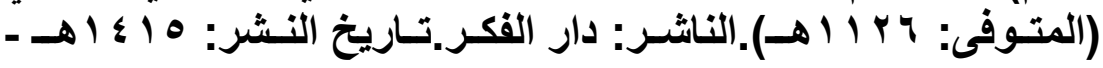
(المو9 99 القاموس المحيط.لمجد الدين أبو طاهر محمد بن يعقوب الفيروزآبـادى

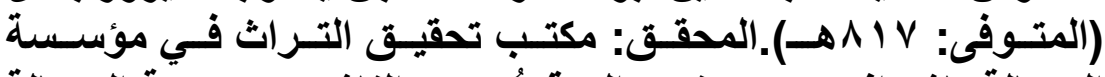

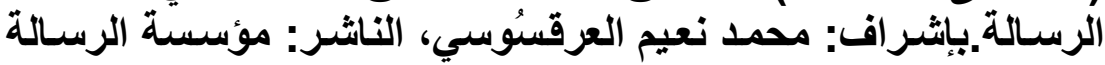

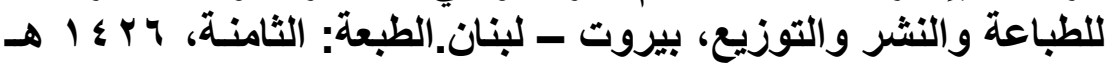

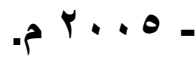
القواعد النورانية الفقهية.لتقي الدين أبي العباس أحمد بن عبد الحليم

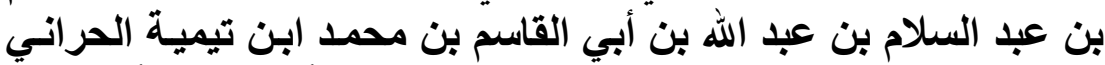

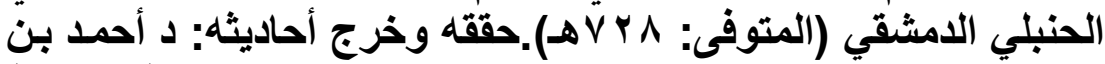

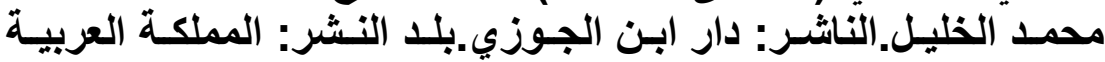

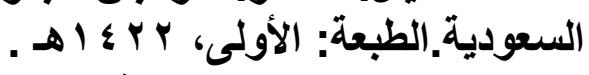

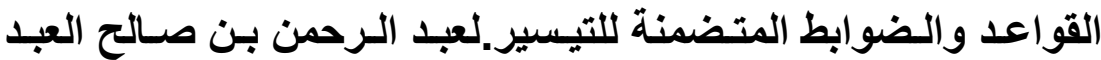
$-\vee \wedge$

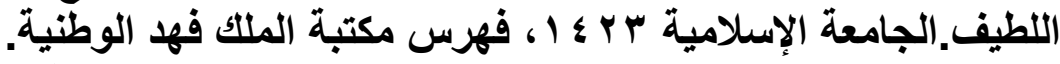

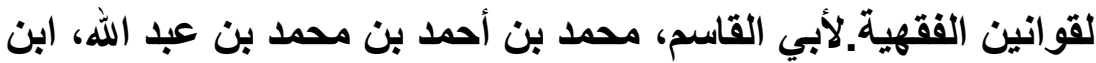
$-v 9$ جزي الكلبي الغرناطي الفي فئي

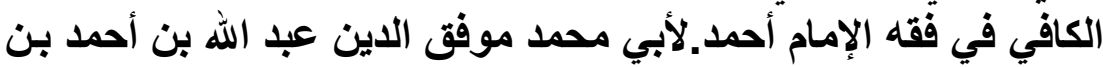

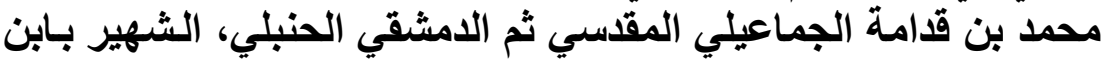
$-V V$ 
قدامة المقدسي (المتوفى: • ب Tهـ) الناشر: دار الكتب العلمية.الطبعة:

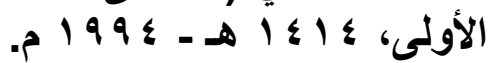
الكافي في فقه أهل المدينة.لأبي عمر يوسف بن بن عبد الله بن محمد بن الهن $-\wedge)$

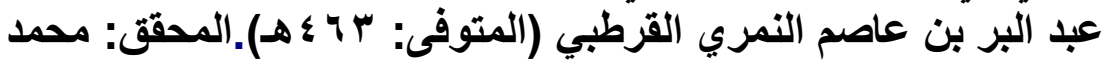

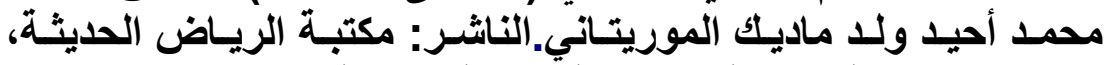

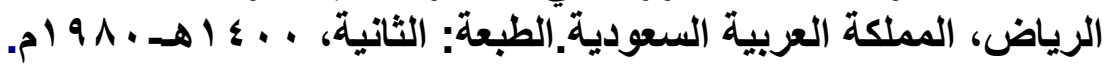

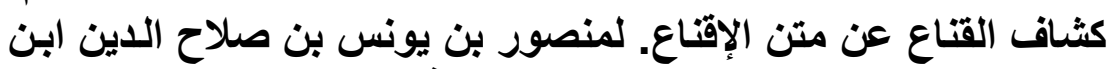
$-\lambda r$

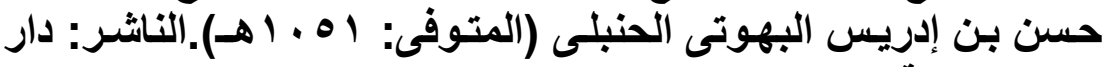

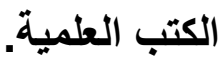

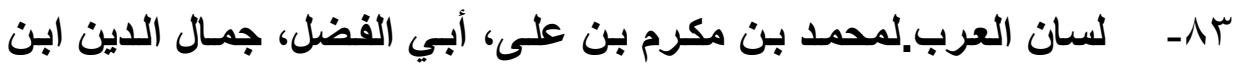

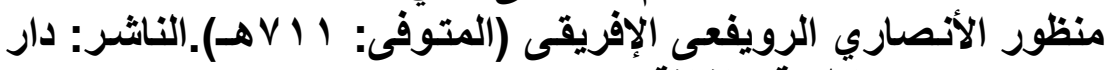

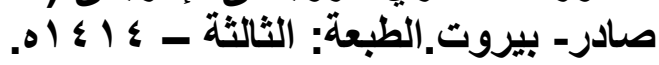

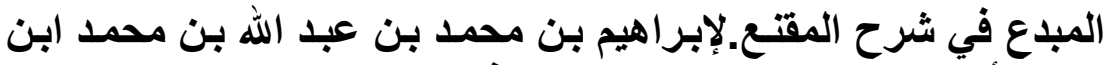
$-\lambda \varepsilon$

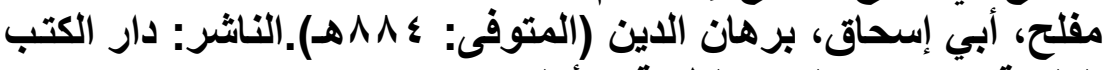

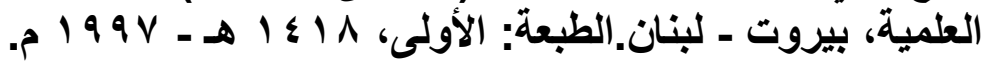

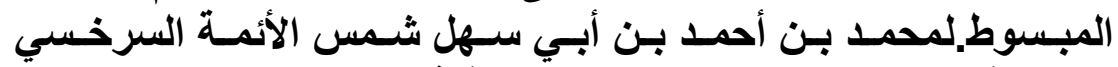
$-10$

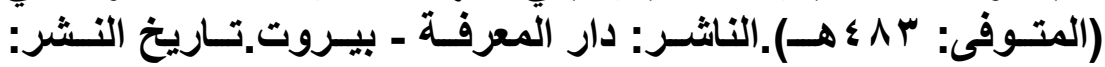

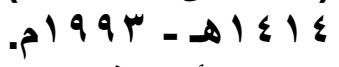

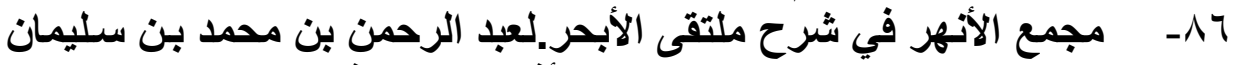

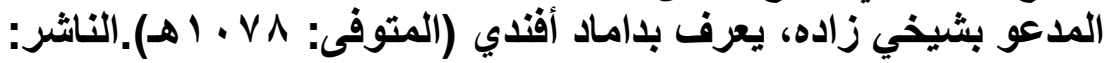

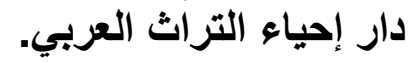

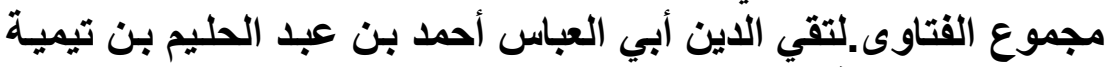
$-\lambda \vee$

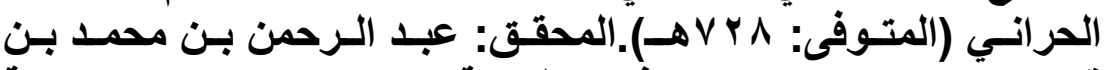

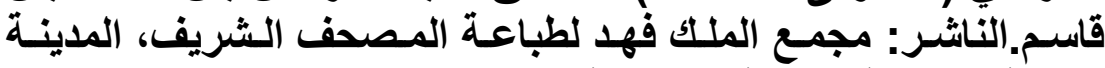

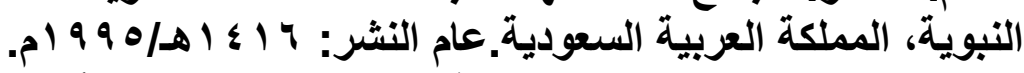

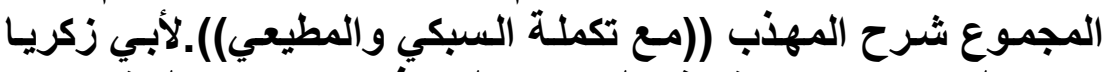
$-\wedge \Lambda$

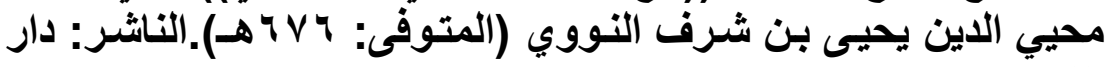

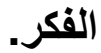

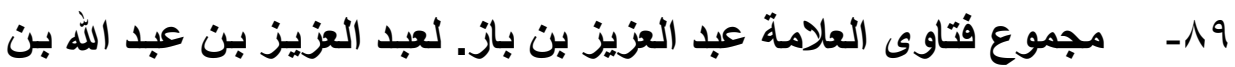

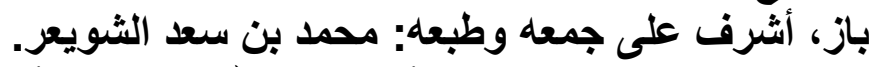

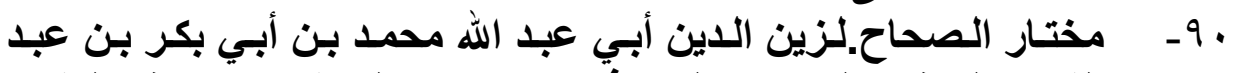

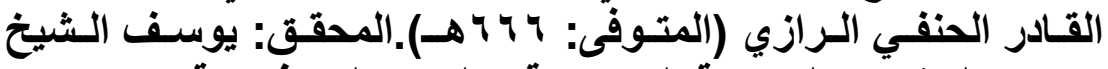

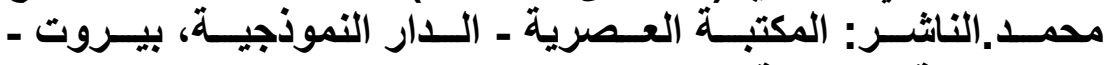

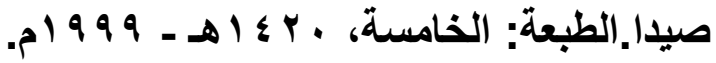
المدونة.لسحنون بن سعيد التنوخي.الناثر: دارية دار الكتب العلمية.الطبعة:

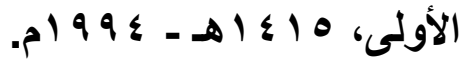




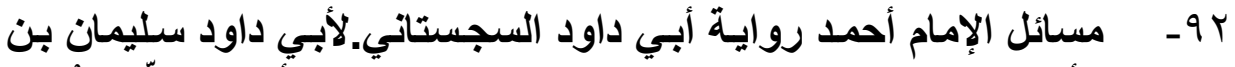

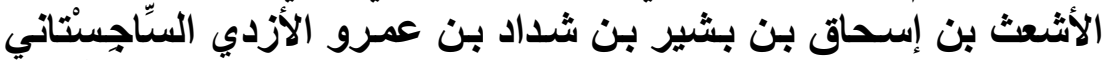

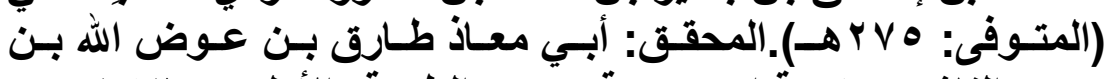

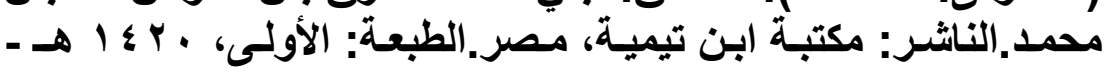
( ) 1999

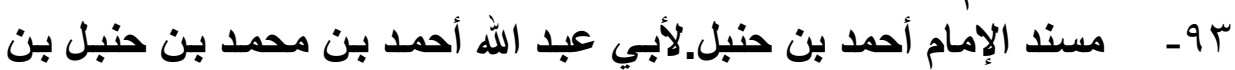

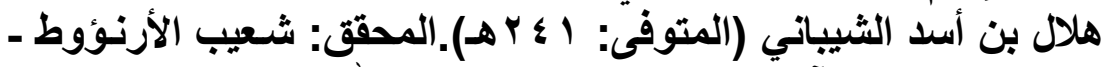

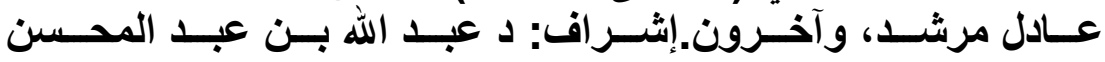

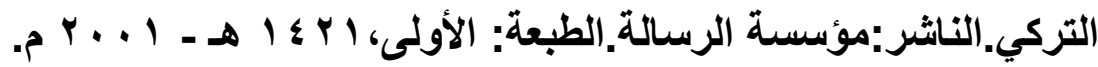

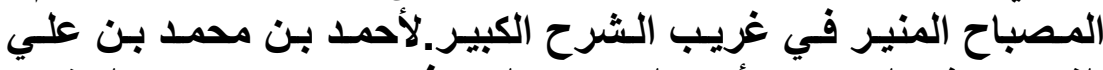

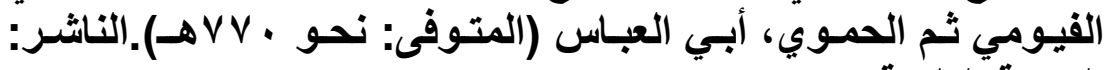
$-9 \leq$ المكتبة العلمية - بيروت العيوي،

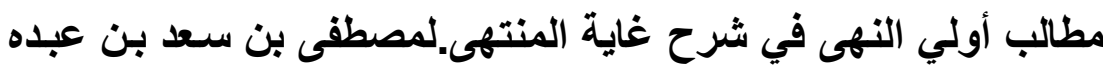

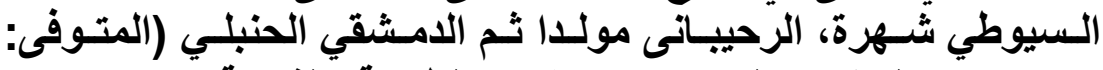

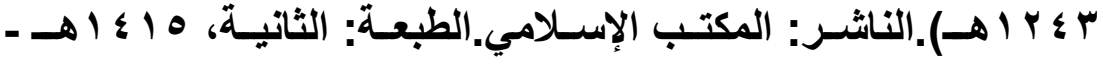
. 998

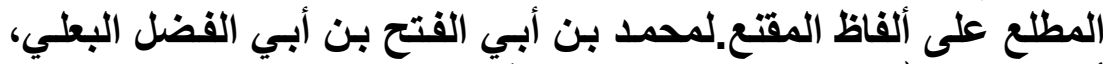

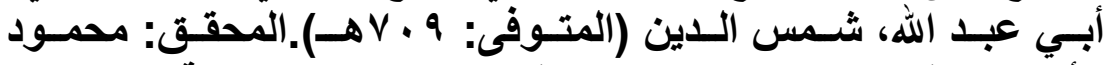

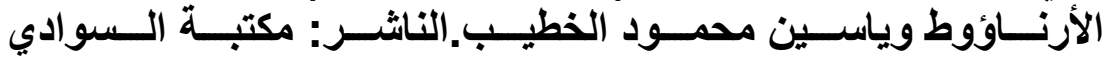

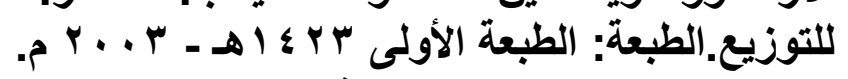

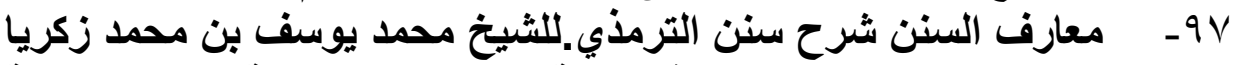

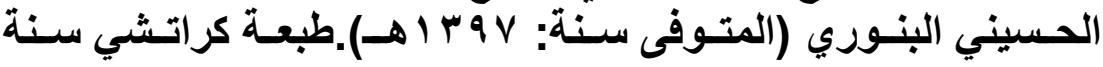

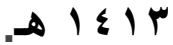

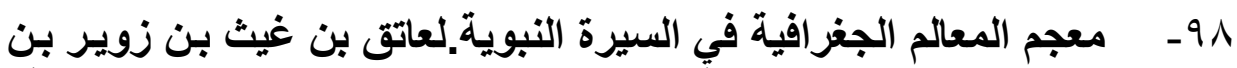

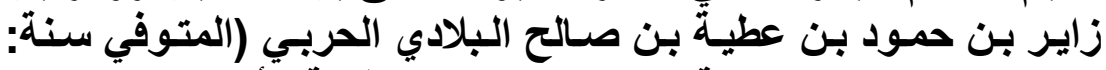

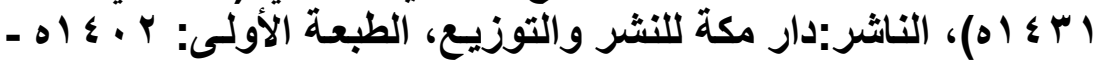
(9)

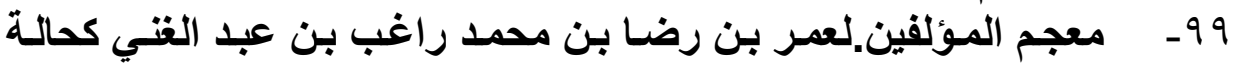

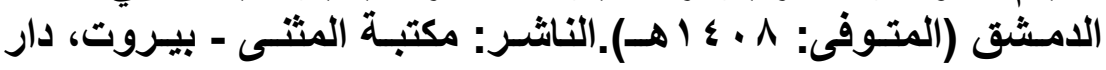

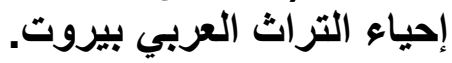

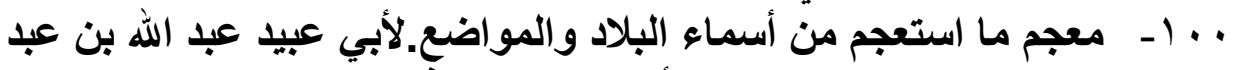

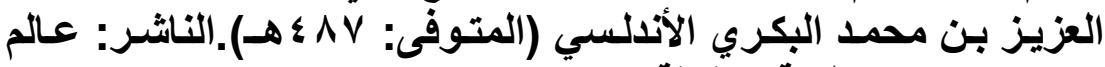

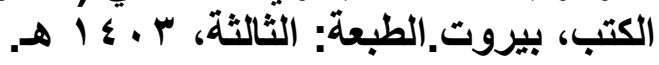

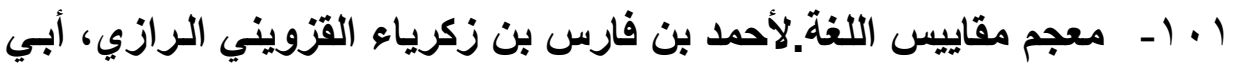

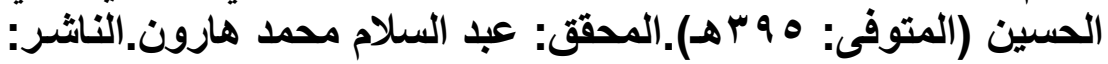

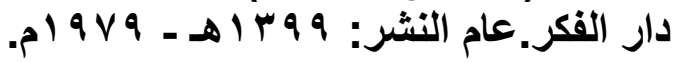

